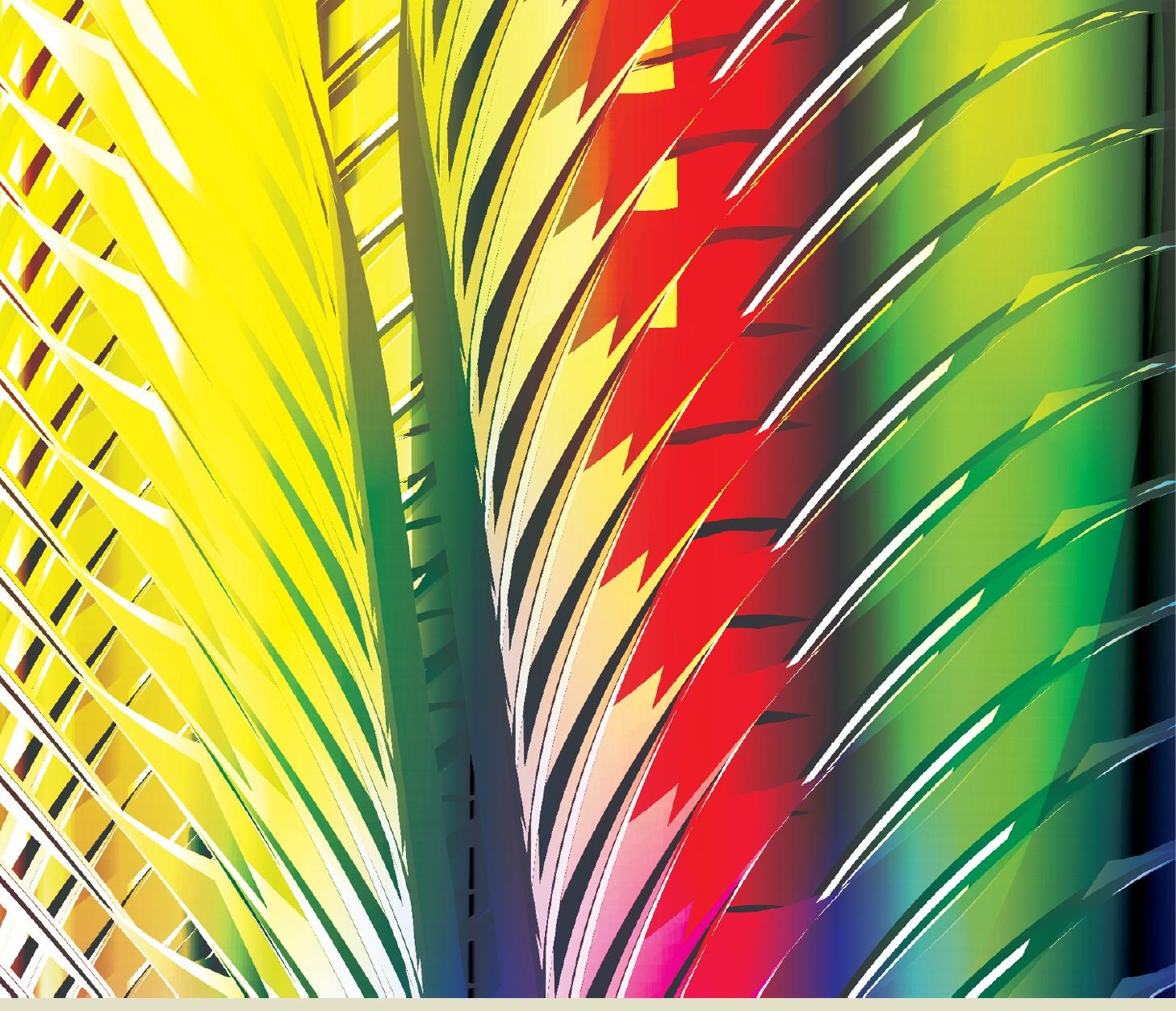

\title{
Vybrané aspekty kulturního vývoje Asie a Afriky
}


Katedra blízkovýchodních studií

Filozofická fakulta

Západočeská univerzita v PIzni

https://doi.org/10.24132/ZCU.2018.07163

\section{8}

\section{Vybrané aspekty kulturního vývoje Asie a Afriky}




\section{Vybrané aspekty kulturního vývoje Asie a Afriky}

Editor:

Lukáš Pecha

Tato publikace byla vydána díky finanční podpoře v rámci projektu Studentská vědecká konference, č. SVK1-2015-013.

Vydání publikace bylo schváleno Vědeckou redakcí Západočeské univerzity v Plzni.

Odborní recenzenti:

doc. PhDr. Luboš Bělka, CSc.

doc. PhDr. Daniel Boušek, Ph.D.

Typografická úprava:

Jakub Pokorný

Grafický návrh obálky:

Iveta Hostašová

Vydala:

Západočeská univerzita v Plzni

P.O.Box 314, Univerzitní 8, 30614 Plzeň

První vydání, 215 stran

Pořadové číslo: 2264, ediční číslo: 55-055-17

Plzeň 2018

https://doi.org/10.24132/ZCU.2018.07163

ISBN 978-80-261-0716-3

(c) Autoři

Západočeská univerzita v PIzni 


\section{Předmluva}

Předkládaná publikace si klade za cíl představit kulturní vývoj rozsáhlého teritoria, jež se rozprostírá od severní Afriky přes Blízký východ až do východní Asie. Odborníci z různých vědeckých a vědecko-pedagogických pracovišt', kteří se dlouhodobě zabývají studiem jednotlivých regionů na tomto teritoriu, předkládají výsledky svých dílčích projektů, které jsou věnovány různým aspektům kulturního vývoje civilisací na území Afriky a Asie v dlouhém časovém úseku sahajícím od starověku až do současnosti.

Platformou, která umožnila presentovat výsledky multidisciplinárního výzkumu vývoje afrických a asijských kultur , byI XV. ročník kolokvia Orientalia Antiqua Nova, které uspořádala Katedra blízkovýchodních studií Filosofické fakulty Západočeské university v Plzni v dubnu 2015. Vě̌íme, že předkládaná publikace bude užitečná pro širokou zainteresovanou veřejnost a podnítí další spolupráci při výzkumu civilisací na africkém a asijském kontinentu.

Lukáš Pecha

editor 


\section{Obsah}

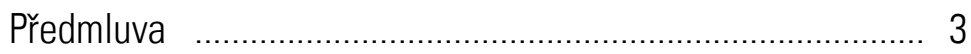

1. KAPITOLA. NÁBOŽENSTVÍ A JAZYKY ............................. 6

Pavel Čech

Poslední interpretace Prvního hříchu ..................................... 7

Maria Galuzina

Jak zničit čarodějnici ..................................................... 18

Jana Jiroušková

„Jen mrtvá ryba pluje po proudu“: Zvir̃ecí tématika

$\checkmark$ africké tradici

Jiř́ Matela

Prostorová konceptualizace: UČl - SOTO a její projevy

v japonském jazyce

Mlada Mikulicová

Kniha hodin v Adamově závěti: Staroegyptský motiv

v arabském středověkém textu

David Rafael Moulis

Judské náboženství 8. století pr. Kr. ve světle archeologie .. 67

Marie Peterková Hlouchová

Rostliny zbožštěné ve slunečním kultu egyptské Staré ríše ... 86 


\section{Michaela Śmiejová}

Emonská proklínací destička: Defixiones jako fenomén ... 102

2. KAPITOLA. POLITIKA A DĚJINY .................................. 119

Michal Habaj

Správní reformy Kambýsa II. v období 530-525 před n. I. . .. 120

Daniel Šichan

Význam Vesetu v mocenské ideologii egyptských

panovníků na přelomu 17. a 18. dynastie

Miroslava Šurinová

Nový pohlad na pokladnice v staroegyptských

pevnostiach z Strednej ríše v Dolnej Núbii

144

3. KAPITOLA. KONTAKTY ZÁPADU A VÝCHODU

161

Ivo Budil

William Winwood Reade a formování britské afrikanistiky .. 162

Vladimír Liščák

První novověcí misionári v Číně (16. století)

Tomáš Matějec

Z minulosti poznávání Blízkého východu v českých

zemích: Veleslavínův překlad Itineraria Sacrae Scripturae

z roku 1592

Lukáš Rybár

Kaukazská Albánia a jej obchodný význam pre Európu

v období staroveku

Summary

214 


\section{KAPITOLA \\ NÁBOŽENSTVÍ A JAZYKY}




\section{Pavel Čech}

\section{Poslední interpretace Prvního hříchu Ugaritica Antiqua Nova 6}

\section{Adamovi}

Počátek Starého zákona od nepaměti zve - ba láká - z nejrůznějších důvodů k nejrůznějším výkladům. Minulému století dominovaly výklady panbabylonské, integrální, fenomenologické, feministické a další. Poslední radikálně odlišná interpretace tohoto tématu vzešla z pera holandského dua teologů a ugaritologů Marjo C. A. Korpelové a jejího emeritovaného učitele Johannese C. de Moora. ${ }^{2}$ Lze ji nejspíše označit za srovnávací „kanaánskou“3. "Srovnávací", nebot ve třetí kapitole věnuje pozornost podobným látkám egyptským, mezopotamským, íránským a řeckým, ale především za „kanaánskou“, nebot zásadní roli hraje jejich porozumění ugaritským textům jako typickému představiteli kanaánské mytologie. ${ }^{5}$ Kapitoly 4-6 se poté věnuji „Reception“ - tedy již něčemu sekundárnímu! - této mytologie ve Starém zákoně, „parabiblických" textech a v Novém zákoně. Zde bude nejprve představena jejich odvážná a svůdná vize původního kanaánského mýtu o počátku lidské společnosti, poté prezentována její diskutabilní místa a na závěr

\footnotetext{
1 Antalík 2005.

2 Korpel-Moor 2014.

3 Se všemi caveat, která se k takto (zne)užívanému adjektivu váží (viz Čech 2011).

4 Similar Motifs in the Ancient World, s. 81-105.

5 The Adamic Myth in the Eastern Mediterranean, s. 5-80. Zda Ugarit patří do kanaánského světa a zda jsou zde zapsané látky místního původu (M. Dietrich - 0. Loretz,) jsou dotazy legitimní, nicméně přesahující obzor tohoto příspěvku.
} 
nabídnuta částečná oprava s využitím dalšího nedávného příspěvku z pera semitisty Richarda C. Steinera. ${ }^{6}$

Oba badatelé vycházejí z mýtu, jenž byl písemně zachycen koncem mladší doby bronzové (kolem roku 1200 př. Kr.) v syrském přístavu Ugarit místním klínopisem na třech tabulkách. Tedy alespoň hypoteticky, nebot' první tabulka tohoto jimi postulovaného celku nebyla nikdy nalezena, druhá (KTU 1.107) je velice fragmentární a třetí (KTU 1.100) dosud nikdo nepovažoval za pokračování té druhé. Druhá i třetí byly, dlužno říci, nalezeny na stejném místě, v knihovně "magického" či „churritského" kněze, byly napsány stejným písařem, patří do žánru ugaritských myticko-magických textů, ${ }^{7}$ kde je paradigmatický př́iběh z roviny božské použit jako návod ke konání na rovině lidské, a sdílejí narativ o hadím uštknutí spojený s vypočítáním členů ugaritského panteonu, mezi nimiž je výsadní pozornost věnována bohu Choronovi. ${ }^{8}$ Od běžného hadího zaříkání - jehož jediným představitelem je v ugaritštině KTU $1.179^{9}$ - se přitom výrazně liší. Oba texty jsou dostupné v českém překladu, který v podstatě odráží současné communis opinio. ${ }^{10}$ Zde rekonstruovaný príběh se od něj pozoruhodně lišíi ${ }^{11}$ a v kostce zní následovně: ${ }^{12}$

6 Steiner 2007 (přepis hebrejštiny podle Čech - Sládek 2009, norma E).

7 Nazývaných porůznu "historiolae“, „paramythologique“ atd. Byly vícekrát edičně zpracovány: Pardee 1988; Dietrich - Loretz 2000, 263-402.

${ }^{8}$ Tento bůh je znám především díky ugaritským textům, vyskytuje se ale už v textech z Mari, ve foinických a punských epigrafech, starozákonní toponomastice, egyptských nápisech a nemnoha dalších textech, jako např. zaklínání z Arslan Taše (pro stručný přehled srov. např. heslo „Horon“ v DDD, 425n.). Společným rysem je jeho chtonická až démonická povaha, což může být přícinou toho, že se nevyskytuje v ugaritských liturgických textech (podobně jako třeba bůh smrti Mótu). Nápadný je jeho poměr k vládci ugaritského panteonu Elovi v obou probíraných textech: v KTU 1.100 je jeho protipólem, uvedeným na druhém konci seznamu bohů, v KTU 1.107, jež vypočítává bohy zpravidla po dvojicích, naopak jeho souputníkem (takový Elův stín?). Podle KTU 1.100 byla jeho sídlem - at' už geografickým či mytologickým - mșd, „pevnost” (srov. heb. Masada).

9 Čech 2004-2005.

10 Stehlík 2003, 314-323, 328-332.

11 Že se interpretace předních badatelů na poli ugaritském „pozoruhodně rozcházejí”, konstatoval již profesor Segert (podle informace prof. Oliveria). Porovnání holandského překladu s překladem 0 . Stehlíka je připojeno v př́loze.

12 Přehledné shrnutí online viz http://www.bibleinterp.com/PDFs/Paper_Korpel_De_ Moor.pdf. 
Hlavní bůh a stvořitel El bydlel zároveň v nebi a u pramenů Eufratu a Tigridu, konkrétně na hoře Ararat - tato „vinice velkých bohü“ je předobrazem biblického ráje. Proti Elově postavení rebeloval bůh Choron, byl však odhalen a svržen na zem, kde, zhrzen, proměnil strom života ve strom smrti (žádný druhý strom „poznání dobrého a zlého" v původním mýtu není) a jal se jej střežit ve formě obřího hada (biblický Livjátan, ugaritský Itn, řecký Ladón)..13ůh či člověk ${ }^{14}$ Adam byl panteonem vyslán, aby tento stav napravil, had jej však uštkl a Adam musel být za pomoci bohyně slunce Šapaš zachráněn. ${ }^{15}$ Následkem této epizody ztratil nesmrtelnost a přetrvání lidského rodu je od té doby zaručeno plozením. ${ }^{16}$ Významnou roli při něm pochopitelně hraje jeho družka Eva, původně zcela pozitivní postava identická s anatolskou bohyní Kubabou-Kybéléa s „ženou dobré duše“ (KTU 1.107 27), jež byla starozákonními autory a redaktory pod vlivem řeckých textů sekundárně dehonestována.

Když tedy plán A jako Adam Elovi nevyšel, uchýlí se k vyjednávání. Konkrétně - a zde precházíme na tabulku KTU 1.100 - pohrozí jménem celého panteonu smrtí všech Choronových potomků - hadů, nevrátí-li Choron strom do původního stavu. Ten se zalekne, souhlasí a odměnou je mu místo strážce nově nastoleného řádu. Na závěr se úspěšně smlouvá o hadím věnu. Hrozba řádu se stává zárukou jeho uchování, ${ }^{17}$ vše nakonec dobře dopadlo a "smrt byla přemožena plozením”. ${ }^{18}$

Nabízi se otázka, jak je možné, že obecně známé prameny se až pod dohledem holandských badatelů spojily v takový mytický veletok?

\footnotetext{
13 Zde končí děj zapsaný na první - nedochované - tabulce, rekonstruovaný primárně podle Historie Filóna z Byblu.

14 "[T]he first humanlike being" (s. 23); „the divine being” (s. 25).

15 Podobně Šapaš v ugaritských mýtech pomáhá bohyni Anat dostat z podsvětí boha Baala (KTU 1.6 iv) a v ugaritské liturgii naopak doprovází do podsvětí zesnulé panovníky (KTU 1.161).

${ }^{16}$ Adam tedy vyměnil vlastní nesmrtelnost za lidský život věčný, podoben křestanskému spasiteli, onomu „druhému Adamovi“.

17 K tomuto motivu ve Starém zákoně srov. Čech 2010 a v pobiblickém judaismu (zejména postava Livjátana) Sládek 2010.

18 „Death is defeated by procreation".
} 
Hlavní príčinou bude fakt, že se odvážili překročit hranici striktního akademického bádání, a to hned několika směry. Zaprvé - masivně rekonstruují poškozená místa, ${ }^{19}$ hlavně v prípadě KTU 1.107. Napřiklad ona „žena dobré duše“ je ve skutečnosti nepríliš vypovídající „[xxxxxx] brá duše“ a vděčí za svoji existenci „practically certain“ rekonstrukci [ațt] țbt npš̌roPodobně prì ikonografickém vytěžování otisků specifických pečetních válečků by stěží někdo jiný - určitě ne editio princeps - za třemi kroužky na jednom z nich hledal ženu reprezentovanou hlavou s ňadry. ${ }^{21}$

Zadruhé - dostupné prameny využívají značně selektivně. Vrátíme-li se k epigrafické rovině, typické je čtení poškozených znaků spiše ve shodě s rekostruovanou dějovou linkou než s dostupnými edicemi (např. právě KTU). Např. hned na 2. řádku KTU 1.107 nečtou ] ${ }^{c} r t$. ilm . rbm, ale ]krm ilm . rbm, „vinice velkých bohü“, čímž získávají ráj, tedy potřebný locus děje. Zjevné je to též při etymologizaci a komparaci vlastních jmen. Jméno „záporného hrdiny“ boha Chorona správně odvodí od semitského kořene *hrr "vedro, sucho" a více či méně přesvědčivě spojí s na první pohled disparátní množinou proprií obsahující kanaánské toponymum Haurán, ${ }^{22}$ babylonské teonymum Erra nebo řecké antroponymum Herakles. Při exkurzi do egyptské mytologie si však překvapivě nevšímají boha Hora (s nímž egyptský Choron sdílí nejen jméno, ale i sokolí podobu), nýbrž Horova odpưrce boha Seta, jemuž je Choron podoben svým ambivalentním charakterem. Podobně při literární komparaci vybírají z jiných děl starověké literatury ty epizody, které mohou podpořit jejich rekonstrukci bez zvláštní snahy vysvětlit ty, které jí odporují. Tak na první pohled zaujme překvapivá blízkost k dějové lince z raně křestanského midraše na první kapitoly knihy Genesis Život Adama a Evy. ${ }^{23}$ Tato skladba spojuje dvě narace o stvoření tím, že druhou, značně odlišnou verzi uvozuje jako Eviny vzpomínky (od A15).

\footnotetext{
19 Nekorunovaným králem moderní ugaritské poezie je Baruch Margalit.

20 Korpel - de Moor 2014, 251, pozn. 33.

21 Korpel - de Moor 2014, 67, fig. 25.

22 Oblast v biblickém Bášánu, takovém „pekle“ kanaánské mytické geografie (del Olmo Lete 1988).

${ }^{23}$ Korpel-de Moor 2014, 190n.
} 
Udivující podobnosti bylo pak dosaženo vybíráním motivů z obou částí, což je stěží obhajitelné. ${ }^{24}$

Deapelativizace je další - a i v tomto prípadě an sich zcela legitimní - specialitou, nebot́ ugaritský klínopis neznačí bohy ani lidi determinativem (mezopotamské dingir a lú), ani nemá velká písmena pro propria. Takže grafémy adm je možno číst jak jako apelativum „červený”, tak jako antroponymum „Adam“, grafémy šd jako „pole”, ale také jako teonymum "Šédu“, atp.

Tím přecházíme $k$ dalšímu výraznému rysu této rekonstrukce - bozi jsou eklekticky spojováni a ztotožňováni, někdy s odkazem na zásahy biblických redaktorů poexilní doby (jako v prípadě Heléla ben Šachara ze 14. kapitoly proroka Izajáše, jenž má být „nepochybným” odrazem původního biblického dábla - Chorona). Tragický hrdina rekonstruovaného mýtu - Adam - je pro změnu ztotožněn se záhadnou postavou zvanou Šarruġaziz, jež se mimo KTU 1.107 nevyskytuje ani v ugaritském, ani v jakémkoli jiném starověkém písemnictví.A odkaz na první pár autoři nacházejí i v „hřebci” a „klisně” ze začátku KTU 1.100.

Z pohledu formálního by bylo překvapivé, že dílo z domu churritského kněze bylo zapsáno na více tabulkách - takové rozsáhlé celky se v ugaritštině vyskytují pouze výjimečně (Baalův cyklus, Legendy o Keretovi a Aqhatovi, snad mýtus o Refájcích) a vždy se našly v domě velekněze na akropoli.

Všechny zmíněné postupy jsou takřka nutnou daní takto masivní rekonstrukci, již lze přirovnat ke starším archeologickým rekonstrukcím, např. právě Masady: doplnění chybějících částí podle dostupných paralel, logických předpokladů a badatelovy preference či fantazie. A podobně jako v prípadě archeologie, i zde je celkový dojem působivý a teoreticky mǔže odpovídat realitě.

Oba autory jsme kritizovali pro nadbytečné využívání vlastních jmen, v jednom př́padě - kromě již zmíněného Hora - však mohla být propriální výtěžnost naopak větší a jejím prizmatem viděný děj ještě bohatší. Jde o etymologii pramáti Evy (ḥwh), kterou badatelé dvakrát

24 Český překlad Josefa Šimandla: Soušek (ed.) 1998, 343-363. 
letmo zmíní. ${ }^{25} \mathrm{Akceptují} \mathrm{přitom} \mathrm{biblickou} \mathrm{lidovou} \mathrm{etymologii} \mathrm{a} \mathrm{s} \mathrm{ní} \mathrm{spo-}$ jený výklad „pramáti všeho živého“ $(G n 3,20)$, naopak odmítají spojení s aramejským h wh nebo syrským hịjā "had" a zejména "hadí" interpretaci egyptských grafémů hww egyptských hieroglyfických textech pyramid. hw we tu součástí hadího zaříkání citovaného přímo v protokanaánštině, proto je třeba brát v tomto kontextu zmíněné aramejské a syrské ekvivalenty vážně. Ze semitské části nápisů, prvně přečtené R. C. Steinerem, ${ }^{26}$ vybíráme ty, které vrhají překvapivé světlo na náš prvotní mýtus:

Výrok 235/1: qw r r r'm ḥw'm ḥw. „Ř́ká RRR matka hadů, matka hadů": r r r dává Steiner do souvislosti s hebrejským onomatopoickým rîr „slina” a považuje za jméno hada, případně i jeho uštknutí (zdráháme se napsat "syčení"). 'mḥw mưže znamenat nejen "matka hadů”, nýbrž i "matka živého“. ${ }^{27}$ Okamžik principiálního rozhodnutí to být nemusí - opakování syntagmy beztak napovídá, že si tu semitský zaříkač hraje s oběma významy. Matka hadů je totiž zároveň matkou života už z toho důvodu, že had je díky svlékání staré kưže a oblékání nové nesmrtelný. Vedle nesmrtelnosti takříkajíc absolutní - božské - jsme tak konfrontováni se dvěma nesmrtelnostmi relativními, získanými jednak skrze lineární plození a jednak skrze periodickou obnovu. ${ }^{28}$ Hadí matka je tedy takovým ekvivalentem boha Chorona, "otce hadů”.

Výrok 236/5: qbbh 'tj 'tj bjtj : „Zaříkejte: pojd', pojd' do mého domu!" Zde bychom - v nejlepší holandské tradici - rádi opravili překlad prvního slova na teonymum Kubaba, tedy očima holandských badatelů na božskou hypostázi pramáti Evy (egyptský originál má skutečně $k-b-b$-h, což může předávat jak Steinerovo qbbh, tak kbbh). Bud' má tedy bohyně Kubaba alias Eva přijít do domu zaříkavače, nebo - a tato interpretace se holandskýma očima prímo nabízí - láká Kubaba kohosi do svého domu. Vezmeme-li do úvahy konec KTU 1.100, je tím pozvaným právě

\footnotetext{
25 Korpel - de Moor 2014, 45; 131, pozn. 111.

${ }^{26}$ lechašim be-protokenaanit bekitvej ha-piramidot: skira rišona al toldot ha-ivrit beelef ha-šliši lifnej ha-sfira.

27 Becking 2012.

28 K protikladu „lineární” versus „periodický” (či cyklický) srov. Eliade 1994.
} 
Choron. ${ }^{29}$ Zdá se, že Kubaba alias Eva měla s primordiálním hadem delší rozhovor a užší kontakt, než připouští biblický text! !30

Výrok 281/12: 'ssh qw qbbh rrr bj: „Zařikání, výrok zaříkejte: RRR mně!” I zde se nabízí vyměnit „zaříkejte“ za Kubabu, která tak žádá (jistě po Choronovi) hada. Ocitujme naposledy z KTU 1.100 73-74: „Dej (mi) tedy hady, plaza dej (mi) tedy jako věno a syna hadího jako můj dar."

Protokanaánská zaříkání proti hadům, tento velmi specifický semitský prínos ke stavbě pyramid, se čtou jako recitace k mýtu zachycenému o tisíc let později v Ugaritu. Do dalšího ohledávání tohoto košatého tématu bude třeba vnést určitou metodologickou kázeň, nicméně se zdá, že holandští badatelé našli klíč od pozapomenutého mýtu a za to je třeba jim poděkovat. I když, vedeni korektní snahou zachránit ekvivalent biblické „matky všeho živého" před hadem, vylili s vaničkou i... Adama.

\section{Appendix: Srovnání překladů KTU 1.107}

0. Stehlík

Ugaritské náboženské texty

1 [ ]

2 [ ] bohové velcí, baldachýn [ ]

3 [ ] v ruce jeho, zbrotilo se potem čelo, zčervenal

4 [ ] uhodil, uštknul [ ] pb/hle

5 [ ] vehementně se snažil uvolnit ústa hada.

6 [ ] uštknutí nevěděl, nerozuměl, jak odstranit jed

7 [ ] jej jed a zkroutil jej jed.
Korpel - de Moor

Adam, Eve, and the Devil

(překlad z angličtiny autor)

[„Kdo za nás půj]jde na [ zemi?]

[na] vinici velkých bohů?" Vůdce byl vyvy̌šen,

[vložili ze]mi do jeho rukou.

Čelo Adamovo se zbrotilo,

[had] vypustil slinu, uštkl [ho]! Hle, hltavá ústa! Hle,

[zuby] žravé! Zoufale zkoušel (to) uvolnit, ale ústa hadí

[držela(?)] Nevěděl, jak spoutat Požírače, ani nerozuměl, jak přemoci jed.

[Naplnil(?)] jej jed, ach, ničitel jej zkroutil.

${ }^{29}$ V překladu 0. Stehlíka: (Choron:) „Otevři dům zaříkávání, otevři dům a vstoupím.“

${ }^{30}$ Holandané svůj prekelad KTU 1.100 72: „otevři dům, at mohu vejít!” doprovodili poznámkou: "The eroticism of the metaphor is evident" (Korpel - de Moor 2014, 264, pozn. 36). 
8 [Padl do md]lob Širuġazuz, naříkal jako hoch

9 [a plakal] jako dítě. Šapš z nebes zavolala:

10 [." ]padl jsi [ ]? Proč padl jsi do mdlob,

11 Širug̉azuzi, a nařikáš ja[ko] hoch, pláčeš jako

12 [dí]tě??" Nařikaje odpověděl [Širugazazuz: ] odpověděl, vrátil se

13 [ ] dcery ó Š[apš? ]

14 [ ] a tak dále v celém [ ] vyprávě[ní]

15 [Šap]š z nebes zavolala: [ ]

16 [ ]

17 [ ]

18 [ ]

19 [ ]

$20[$ ]

21 [ ]

22[]

$23[1]$

24[]

25[]

$26[$ ]

27 [ ]

28 [ ] do pole. Padl [ ]

29 [ ] klesl [ ] Choron

30 [ ] král

31 [ ] Choron
[Padlo ma]so Šarrugiazizovo, naříkal jako hoch

[a plakal] jako malý. Šapš z nebes zavolala:

[„Hle! Proč] jsi padl, ach, můj přriteli??]

Proč padlo maso

Šarrugazizovo? A (proč) naříkáš jako hoch, pláčeš jako

dítě?" Nato [Šarruġaziz] k jejím slovům:

Prosím, odpověz mi, má stvořitelko

[Šapš:] [Proč já ke smrti] kráćím?

[Vr]at se ditto k celé recitaci.

[Šap]š z nebes volala, [ ] kvílela.

[Úúú!] Chci odř́kat [žalozpěv(?) ]

[Odpo]ví: „Jak hořké!

Horkost se lije z Ló[tána(?) ] hořkost

světa.

Jeho [ ] kněze zbavil(a) [ ] Jdou bosi.

[Zapom]něl(?) ruku, zapomněl n[ohu].

Ša[pšu zakřičela] na potopu:

její [ruce(?)] kadeře[její hlavy, v plá(?)]či

zahořknu!

[Proč] byl A[dam] vyvýšen? [ ]

[ ]Hle! Ne[ ]

[d]át [mi] někoho, kdo je odsouzen

zemřít. [ ]

[ ] jed [ ]

[ ]

[ ]

[žena] dobré duše[. ]

Utíkej [k boh]ovi Šédu,opa[kuj mu:

„Ach, Šédu,] ted" následuj!

[Zvedni(?)] obě hory, ach [bože! A sestup do domul Choronova.

[A dél]ka milos[ti ](?) s tebou.

[ sv]až ha[da ], ó Chorone! 
32 [ ] pobřeží jeho [ .] Shromáždi, Šapš, z hor

33 [hustý mrak,] ze země shromáždi [moc je]du.

34 Shromáždi, Šapš, z hor hustý mrak, ze země [moc] jedu.

$35 Z$ úst (toho, který) uštknul, jed, z úst požírače

36 [toxin] shromáždi. Jed [ ] at shromáždí jed.

37 [Shromáždi, Ša]pš, z hor hustlý mrak, ze země moc

38 [je]du[shromáždi.] El a Choron at shromáždí jed,

39 [Baal] a Dagan [at sh]romáždí jed, Anat a Aštart

40 [at' sh]romáždí jed, Jarich a Rešef at shromáždí jed,

41 [Ašta]r a Aštapar at' shromáǎdí jed, Zizzu a Kamaš

42 at shromáždí jed, Malik v Aštart at shromáždí jed.

43 Košar a Chasis at shromáždí jed, Šachar a Šalim

44 at shromáždí jed. Shromáždi, [Ša]pš, z hor hustý mrak, ze země

45 [kéž shromáž]díš jed, z úst (toho, který) uštknul, jed, z úst požírače toxin.

46 [ ] neštěkala [ ] dala pokrm (tomu, který) uštknul

47 [ ] (ten, který) uštknul, Šapš,

48 [ ] pomažeš kouzelníky

49 [ ] v den, narodila se

50

51

52

53

54
Shromáždi to pokrytí, ó Chamane!, [shromáždi, ó Ša]pš, z hor

[jed,] sílu na zemi. Shromáždi jed

z hor, ó Šapš, mlhu na zemi.

[Shromáždi] jed z úst Hořkého, destrukci z úst Požírače.

[Necht' otec] shromáždí jed, necht́ shromáždí jed.

Necht Šapš [shromáždí] opar na horách, na zemi moc

jedova[tých] rtů. Necht' El a Choron

shromáždí jed,

necht' [Baal] a Dagan shromáždí jed,

necht' Anat a Aštarta

shromáždí jed, necht Jarich a Rašpu

shromáždí jed,

necht' Aštar a Aštapar shromáždí jed,

necht' Zizzu a Kamaš

shromáždí jed, necht' Málik v Aštart

shromáždí jed,

necht' Košar a Chasis shromáždí jed,

necht Šachar a Šalim shromáždí

jed. Shromáždi, Šapš, opar z hor, na zemi

jedovaté rty, z úst Hořkého destrukci, z úst Požírače paralýzu chromého.

[Přijm]i, vydráždi říjného samce, bud’ horká, vypust' krev!

[ ] vypust život!

[ ] opřu ničitele zdravých dětí

[ ] já sám se pokloním v den, kdy porodišs.

[ ] on jí/krmí

[ ] velí bozi [ ] položí

[ dce]ry lidské životem [porazí(?)] smrt.

[ ] ona nezemře [ ] Košárót

[ ] jídlo [ ] 


\section{Literatura}

Antalík, D. 2005: Jak srovnávat nesrovnatelné. Strategie mezináboženské komparace (Sborníky, slovníky, učební texty 31), Praha: Oikoymenh.

Becking, B. 2012: „Semitisch sprekende slangen. Over de betekenis voor de wetenschap van het Oude Testament van een bijzondere vondst in de piramideteksten“, in: Ned ThT 66, 203-217.

Čech, P. 2004-2005: „'Kouzla čáry'. RS 92.2014: Ugaritské zaříkání proti nebezpečným druhům", Chatreššar, 29-40.

Čech, P. 2010: „Chaos, ba prímo tohuvabohu ve Starém zákoně“, in: T. Vítek - J. Starý-D. Antalík (eds.), Řád a chaos v archaických kulturách (Svět archaických kultur 6), Praha: Herrmann \& synové, 87-100.

Čech, P. 2011: „Kanaánské písemnictví do konce 2. tisíciletí př. Kr.”, in: J. Mynářová et al. (eds.), Písemnictví starého Předního východu (Starověké písemnictví Levanty 1), Praha: Oikoymenh, 270-281.

Čech, P. - Sládek, P. 2009: „Transliterace a transkripce hebrejštiny: základní problémy a návrhy jejich řešení", Listy filologické 132, 305-339.

DDD: van der Toorn, K. - Becking, B. - van der Horst, P. W. (eds.) 1999: Dictionary of Deities and Demons in the Bible, Leiden: Brill (2. vydání). del Olmo Lete, G. 1988: „Bašan o el 'infierno' cananeo“", Studi Epigrafici e Linguistici sul Vicino Oriente Antiquo 5, 51-60.

Dietrich, M. - Loretz, 0. 2000: Studien zu den ugaritischen Texten I: Mythos und Ritual in KTU 1.12, 1.24, 1.96, 1.100 und 1.114 (AOAT 269/1), Münster: Ugarit-Verlag.

Eliade, M. 1994: Mýtus o věčném návratu, Praha: Oikumene.

Korpel, M. C. A. - de Moor, J. C. 2014: Adam, Eve, and the Devil. A New Beginning (Hebrew Bible Monographs 65), Sheffield: Phoenix Press.

Pardee, D. 1988: Les Textes para-mythologiques de la $24^{e}$ campagne (1961) (Ras Shamra-Ougarit 4; Mémoire 77), Paris: Éditions Recherches sur les civilizations. 
Sládek, P. 2010: „Rád a jeho narušení v rabínském judaismu formativního období", in: T. Vítek - J. Starý - D. Antalík (eds.), Káa a chaos v archaických kulturách (Svět archaických kultur 6), Praha: Herrmann \& synové, 101-127.

Soušek, Z. (ed.) 1998: Knihy tajemství a moudrosti Il. Mimobiblické židovské spisy: pseudepigrafy, Praha: Vyšehrad.

Stehlík, 0. 2003: Ugaritské náboženské texty. Kanaánské mýty, legendy, žalmy, liturgie, věštby a zařikávání pozdní doby bronzové, Praha: Vyšehrad.

Steiner, R. 2007: lechašim be-protokenaanit bekitvej ha-piramidot: skira rišona al toldot ha-ivrit be-elef ha-šliši lifnej ha-sfira. Zvaná přednáška na Hebrejské univerzitě, Jeruzalém 2007, dříve dostupná online (http://hebrew-academy.huji.ac.il/PDF/steiner.pdf). 


\section{Maria Galuzina}

\section{Jak zničit čarodějnici}

Už od nejstarších dob byla magie (egyptsky ḥq3, akkadsky kaššāpūtu / kišpu) nedílnou součástí jak náboženského, tak každodenního života starověkého Předního východu. Pokud definujeme magii jako „religiózní chování, které se snaží ovlivnit život, zdraví a úspěch jedince či komunity“31, tak se nám logicky rozdělí na legitimní (tzv. „bílou magii“) a neligitimní (tzv. „černou magii.") 0 tom, co je bílá, a co černá magie, Ize uvažovat donekonečna, ale i ve starověku záleželo hlavně na úhlu pohledu. Každý může odůvodněně ríct, že na jeho straně je magie bílá, když magie, používaná proti němu, je ta černá. Ale z egyptských a mezopotamských príkladů vidíme, že hranice mezi bílou a černou magií není přesně stanovena a často se překračuje.

Přestože se na první pohled mưže zdát, že magické praktiky v Egyptě a Mezopotámii jsou celkem odlišné (stejně jako charakter dochovaných pramenů), použití figurek demonstruje velmi podobné postupy a principy fungování - a tím umožňuje srovnání a vyvolává otázku, jestli tyto praktiky vznikaly na sobě nezávisle, nebo byly sdílené a přenášené z jedné kultury do druhé.

Hlavním principem jak egyptské, tak mezopotamské magie byl tzv. „princip přenášení" (anglicky principle of transference"32), založený na tom, že magie se jako dynamická síla pochybuje mezi materiálním a duchovním světem a může „přenášet” podstatu a vlastnosti jakékoli

31 Farber 2000, 1896.

32 Pinch 2006, 100; Jacq 1985, 9-10. 
osoby do materiálního objektu - magické figurky. Tímto způsobem se magická figurka stává tzv. „the substitute body“ - mentálním obrazem či modelem toho, koho reprezentuje. ${ }^{33}$ "Princip přenášení" funguje v Egyptě a Mezopotámii na všech rovinách, bud' to magické figurky a sochy, nebo vešebti a modely v egyptských hrobkách. Pomocí rituálu Otevírání Úst v Egyptě a rituálů Umývání a Otevírání Úst v Mezopotámii byl materiální objekt „oživován” a stával se součástí kosmu.

Zajímavým bodem, ve kterém se Egypt a Mezopotámie liší, je extrémní důležitost pojmenování v Egyptě a častá anonymita figurek v Mezopotámii. Zatímco v Egyptě jméno je podstatou bytosti a musí být nejen na figurce napsáno, ale i vyslovováno během rituálu³ , v Mezopotámii figurky čarodějnic jména nemají a jsou obvykle označovány pouze jako „můj čaroděj / moje čarodějnice." ${ }^{35}$ Jména mají jen jasně definovaní nepřátelé lidstva (např́klad, démonické bytosti Lamaštu a Pazuzu), což mưže napovídat, že na rozdíl od Egypta, kde neprítel musel být vždycky přesně identifikován, v Mezopotámii se za slovem „čarodějnice“ často skrývají různorodé, tajemné a neznámé síly.

Když se podíváme na př́klady magických figurek z Egypta, zjistíme že se nejčastěji vyráběly z netrvanlivých materiálů: z hlíny, vosku, dřeva nebo měkkých kamenů a v Mezopotámii také z těsta, loje či živice. ${ }^{36}$ Jelikož tyto figurky byly vyráběny ke zničení během rituálu, materiál vždy odpovídal způsobu zničení: tak, voskové či dřevěné figurky byly určeny k upálení, kdežto figurky z hlíny, těsta a měkkých kamenů - ke zničení šlapáním, rozbití na kusy nebo k pohřbívání. Právě tato skutečnost mưže za to, že máme k dispozici velmi málo dochovaných figurek, z nichž některé byly nalezeny rozbité a musely být znova sestaveny archeology.

Egyptské figurky mají vždy jasný cizí vzhled, oblečení a účes. Nejvýraznějším rysem ale jsou jejich ruce, zavázané vzadu jako u válečných zajatců (obrázek 1). Mladší figurky z Pozdní a Řecko-Římské doby občas

\footnotetext{
33 Jacq 1985, 59-60.

34 Jacq $1985,49-52$.

35 Abusch - Schwemer 2011, 301-305.

36 Pinch 2006, 90-103; Abusch - Schwemer 2011, 2.
} 


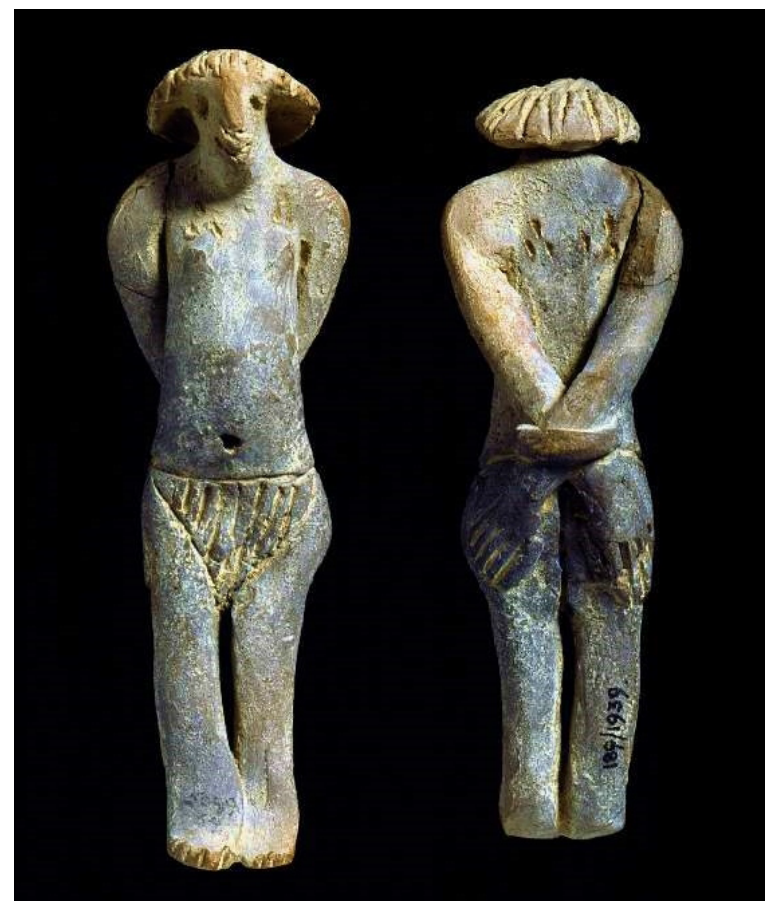

Obrázek 1

mají uvnitř kus „biologického materiálu“ oběti (například vlasy) ${ }^{37}$, a nebo jsou propíchnuté šípy - jak ukazuje známá figurka z pařǐžského Louvru (obrázek 2).

Magické figurky „čarodějnic” z Mezopotámie se dochovaly jen výjimečně, a to ve fragmentárním stavu (obrázek 3 - figurka z lokality Tell-ed-Der), ale právě tyto nálezy pomohly vědcům rekonstruovat, jak tyto figurky běžně vypadaly. ${ }^{38}$ (obrázek 4 - rekonstrukce Daniela Schwemera.)

37 Pinch 2006, 90-91.

${ }^{38}$ Corpus of Mesopotamian Anti-Witchcraft Rituals online: http://www.cmawro. altorientalistik.uni-wuerzburg.de/magic_witchcraft/witches/ (31. 5. 2015), http:// www.cmawro.altorientalistik.uni-wuerzburg.de/magic_witchcraft/anti_witchcraft_ rituals/ (31. 5. 2015). 


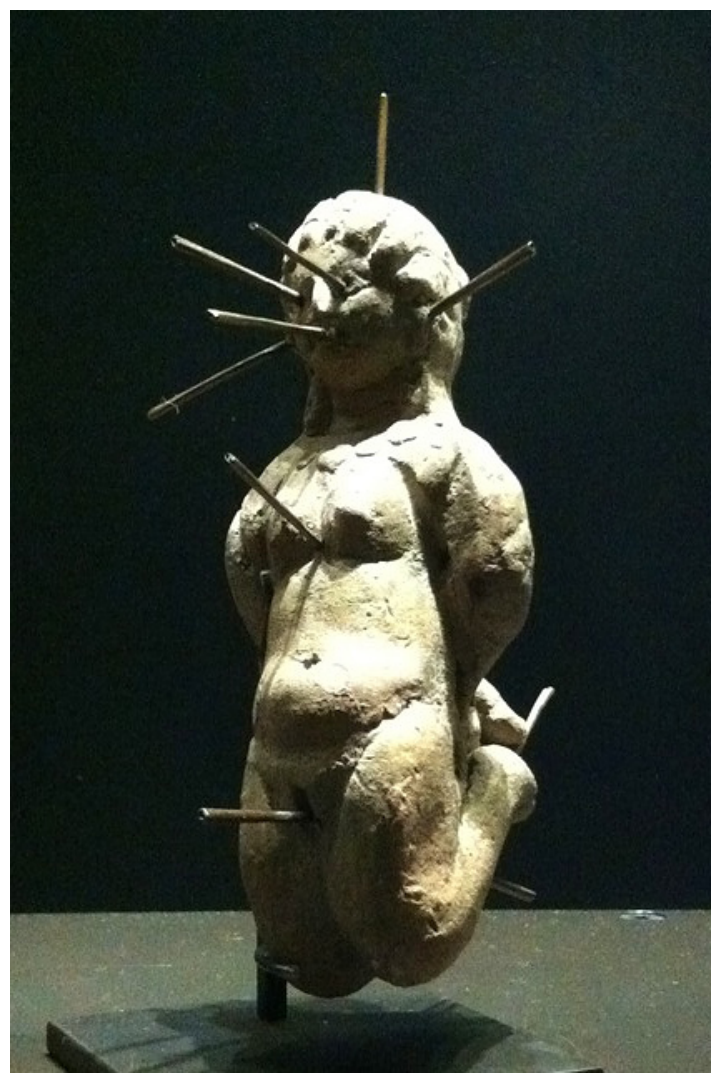

\section{Obrázek 2}

Koho tyhle figurky zobrazuji? Jinými slovy - kdo je neprítel? Jakmile si položíme tuto otázku, vznikne zásadní rozdíl mezi Egyptem a Mezopotámií. Egyptské prameny můžeme rozdělit na dvě skupiny: první funguje na úrovni státu, kde nepř́telem je jakýkoliv nepř́tel Egypta a krále (nejčastěji cizí vládce nebo stát); druhá, mnohem menší skupinka funguje na úrovni jedince, který se potýká s nepř́telem lidské či nadlidské povahy. Mezopotamské prameny spadají výhradně do druhé skupiny, a přitom nepřítel lidské povahy je nazýván akkadskými výrazy kaššāpu / kaššaptu, které překládáme jako čaroděj / čarodějnice. 


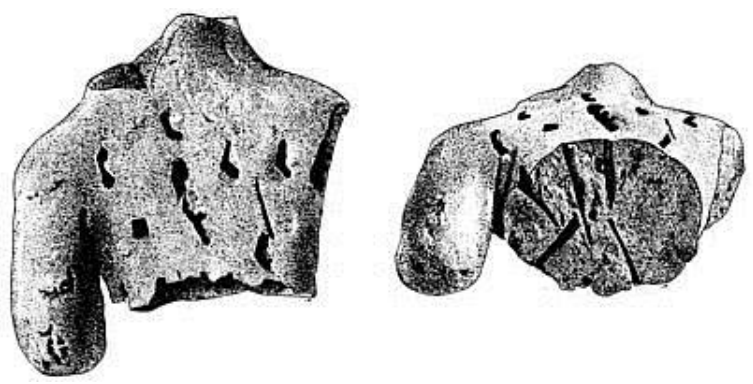

Obrázek 3

V širším slova smyslu pojem "čarodějnice" označuje v mezopotamských textech jakéhokoli nepřítele, který ohrožuje zdraví a úspěch někoho jiného pomocí magie. ${ }^{39}$ Zdá se, že čarodějnictví - konkrétně působení "zlé čarodějnice" (akkadsky kaššaptu lemuttu) - bylo v Mezopotámii zdůvodněním jakéhokoliv neúspěchu, nezdaru, nemoci či neštěstí. Z Egypta tolik zpráv o čarodějnicích nemáme, ale několik dochovaných zaříkání proti čarodějnictví (egyptský hmw-r') popisují čarodějnici jako cizinku z Asie nebo Núbie. ${ }^{40}$ Tahle vazba je velmi charakteristická pro Egypt, z jehož pohledu každý cizinec je apriori nepřítelem, a je spojován, bud' s bohem Sutechem, jako patronem cizinců a cizích zemí, a nebo s tradičním egyptským archetypem nepřítele - podsvětním hadem Apopem, který symbolizuje neřád a chaos a je každodenně poražen slunečním bohem Re. Apop je neprítelem a protikladem světového řádu Maat - a stejně tak, nepř́telem Maat je každý nepřítel Egypta.

Prameny, ze kterých čerpáme, jsou pro Egypt a Mezopotámii dost rozmanité. Nejstarším dokladem použití magických figurek v Egyptě je povídka z papyru Westcar, vyprávějící příběh egyptského hodnostáře, který pro pomstu nevěrné manželce vyrobil voskovou figurku krokodýla, kterou následně oživil pomocí magie. ${ }^{41}$ Dalším jedinečným pramenem je tzv. "harémové spiknutí" z doby 19.dynastie, během kterého byl zavražděn panovník Ramesse III. Ze soudních dokumentů víme,

\footnotetext{
39 Abusch - Schwemer 2011, 2-6.

40 Borghouts 1978, 42.

41 Pinch 2006, 96-97.
} 

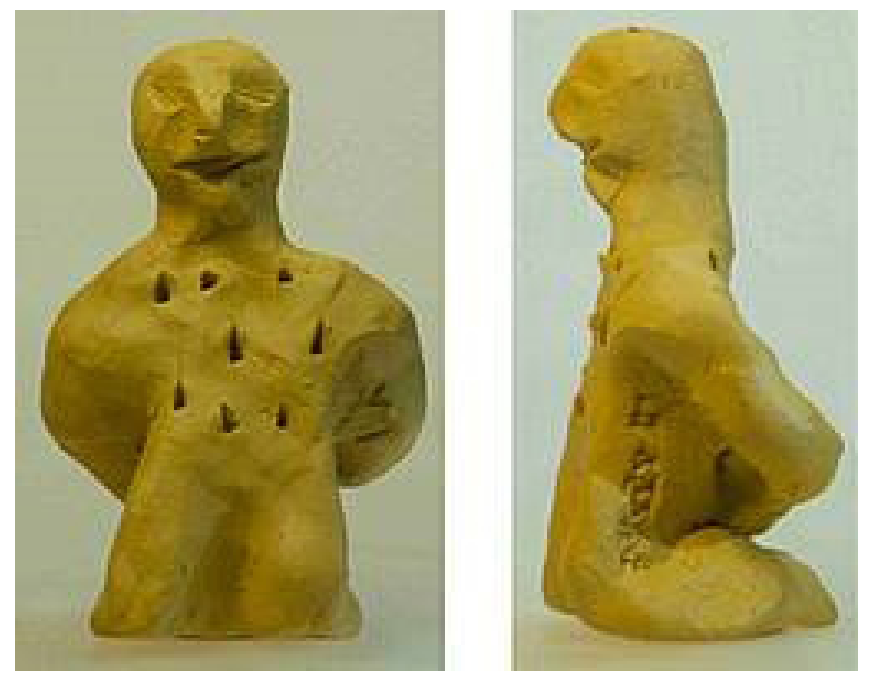

\section{Obrázek 4}

že pachatelé byli obviněni mimo jiné také $v$ tom, že se zmocnili knih o magii v palácové knihovně a provozovali černou magii s použitím figurek, zobrazujících krále, kterého tímto způsobem plánovali usmrtit.t. ${ }^{42}$ Nejznámějším príkladem egyptské destruktivní magie ale je soubor tzv. „proklínacích textư” (anglicky „Execration texts”) z núbijské pevnosti Mirgissa a Memfidské nekropole. V Mirgisse bylo nalezeno cca 350 magických figurek, popsaných hieratickým písmem. To jsou klasické figurky vládců Núbie, Libye a Palestiny v podobě válečných zajatců (obrázek 5). Velmi zajímavá je také skutečnost, že vedle cizincủ se našlo i několik figurek egyptských zločinců a zrádců, což je pro Egypt zcela výjimečné. Tyto figurky byly proklínány a pak zničeny či pohřbívány během rituálů. ${ }^{43} Z$ Pozdní a Řecko-Římské doby máme několik povídek, které se odvolávají na příběh z papyru Westcar a opakují tradiční motivy. Nejzajímavější v tomto ohledu je povídka o núbijském čaroději, který se odvážil provozovat černou magii proti faraonovi

${ }_{42}$ Redford 2002, 30-150.

${ }^{43}$ Pinch 2006, 93; Kriech Ritner 2008, 136-170. https://oi.uchicago.edu/sites/ oi.uchicago.edu/files/uploads/shared/docs/saoc54_4th.pdf (31. 5. 2015). 


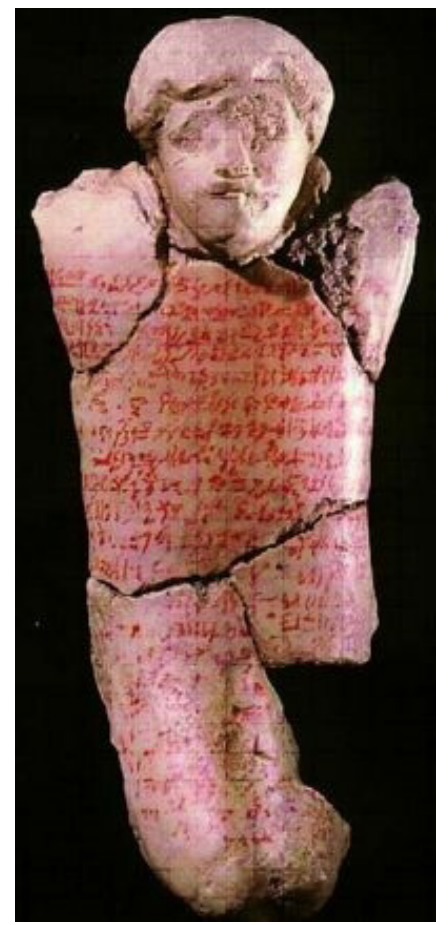

Obrázek 5

Siamunovi a pak byl faraonem (samozřejmě pomocí „bílé magie“) pomstěn. ${ }^{44}$ Tato povídka nejen obsahuje již známé motivy, jako pomsta či motiv „vrácení kletby” tomu, kdo ji posílá, ale také svědčí o značném rozšîrení praktik destruktivní magie v Pozdní a Řecko-Ǩímské době.

Hlavním mezopotamským zdrojem je korpus akkadských zařikání a rituálů proti čarodějüm (tzv. „anti-witchcraft rituals”) s názvem „Maqlu” („Burning”), který v nedávné době zpracovali badatelé Tzvi Abusch a Daniel Schwemer. ${ }^{45}$ Celý korpus čitá cca 100 zaříkání, a jeho standardní verze obsahuje 8 tabulek. Přestože tento soubor byl rozšřren

\footnotetext{
44 Pinch 2006, 95-96.

45 Abusch - Schwemer 2011; Corpus of Mesopotamian Anti-Witchcraft Rituals online: http://www.cmawro.altorientalistik.uni-wuerzburg.de/startseite/ (31. 5. 2015).
} 
na území celé Mezopotámie, největší počet tabulek pochází z Ninivské knihovny a několika soukromých knihoven mezopotamských knězů a lékařủ āšipu. Centrální motivy Maqlu jsou velmi podobné jak egyptskému motivu „vrácení kletby," tak i motivu symbolického „obrácení osudu” („reversal of fate." ${ }^{46}$ ) Samotný rituál Maqlu pravděpodobně vznikl ve vesnickém prostředí a na začátku měl za cíl pouze obranu proti zlu a „černé magii“ místních čarodějnic. Postupně se ale rozšîril a rozrostl do 100 zaříkání, což později vyvrcholilo jeho začleněním do asyrského královského rituálu Bitt rimki. ${ }^{47}$

Magický rituál s použitím figurek se jak v Egyptě, tak v Mezopotámii skládal ze dvou stejně důležitých částí: magických slov na jedné straně, a mechanického činu s figurkou na straně druhé. Cílem rituálu byla bud’ ochrana a prevence zla, a nebo „odvrácení“ zla, které se již uskutečnilo, pomocí rekonstrukce celého incidentu a jeho symbolického „odčinění" či „napravení" - a tím pádem "obrácení osudu." ${ }^{48} \mathrm{~V}$ rituálech s použitím magických figurek manipulace s figurkou musely odpovídat proneseným slovům, která zpravidla děj popisovala nebo se na něj odvolávala. Je velmi pozoruhodné, že v egyptských textech instrukce ohledně figurek bud' úplně chybí, a nebo jsou doplněny na konci jednou větou, např́klad: „Slova musí být pronesena nad voskovou figurkou ženy." ${ }^{49}$ Mezopotamský rituál Maqlu naopak detailně popisuje manipulace s figurkami a je skutečným manuálem pro kněze. Například: „Jestliže magie byla použita proti někomu... uděláš figurky čaroděje a čarodějnice, dvě z hlíny, dvě z těsta, dvě z loje, dvě z živice, dvě z vosku, dvě z cedrového dřeva a dvě z tamaryšku. Vezmeš je a řekneš tohle zaříkání třikrát." ${ }^{50}$

Magický děj rituálu vždy zahrnuje trojici účastníků: obět či pacienta, postiženého nemocí nebo čarodějnictvím; nepřítele (čarodějnici,

\footnotetext{
${ }^{46}$ Corpus of Mesopotamian Anti-Witchcraft Rituals online: http://www.cmawro. altorientalistik.uni-wuerzburg.de/magic_witchcraft/anti_witchcraft_rituals/ (31. 5. 2015). 47 Abusch 2002, 113-162.

48 Corpus of Mesopotamian Anti-Witchcraft Rituals online: http://www.cmawro. altorientalistik.uni-wuerzburg.de/magic_witchcraft/anti_witchcraft_rituals/ (31. 5. 2015).

49 Borghouts 1978, 20-40.

50 Abusch-Schwemer 2011, 301.
} 
démona, etc); a kněze (egyptsky Hk'u, swnw nebo s'u; akkadsky āšipu), který musí černou magii zničit a obět zachránit. Zásadní rozdíly mezi egyptským a mezopotamským textem Ize demonstrovat na několika krátkých příkladech. Egyptské zaříkání je zpravidla mnohem kratší a mǔže, ale nemusí obsahovat na konci instrukce ohledně toho nad kým nebo čím text musí být pronesen. Text samotný se vždy odvolává na archetypickou situaci z egyptské mytologie, kde nejčastějšími účastníky jsou bůh Re; Re a Apop nebo Isis a její syn Horus - a tímto způsobem ztotožňuje pacienta s jedním z bohů: „[The crew] stood still, (saying): Re is suffering from his belly! (.......) If he spends a time suffering from it, will then the god live on underneath?" "Let an appeal be made to the opening of the West Region through the soil. As soon as he has placed his hand on <his> belly, his suffering will begin to be healed!" Words to be said over a woman's statue of clay. " ${ }^{11}$ Nebo zaříkání proti čarodějnici: "Break out, Asiatic woman there, who has come from the hill country, Nubian woman, who has come from the desert plateau! Are you a slave woman? Then come as <his> vomit. Are you a noble woman?Then come as his piss. Come as the slime of his nose, come as the sweat of his limbs! My arms are over this child - the arms of Isis are over him, as she put her arms over her son Horus. "52

Mezopotamský text tradičně začíná protazi „jestliže“, za které následuje apodoze „a pak." Jako př́klad cituji fragmenty z korpusu akkadských zaříkání proti čarodějům, konkrétně standardní rituál před Šamašem ${ }^{53 .}$ "[lf] a man's head keeps on hurting him, he constantly has vertigo, his [bod]y keeps causing him pain (.....), then his enemy has encircled that man with witchcraft..." Dále text podrobně popisuje kolik a jakých figurek musí být vyrobeno a jaké manipulace je třeba s nimi provést, a přitom paralelně uvádí text zaříkání, které musí být pronesen. Velmi zajímavá je nejen anonymita čarodějů, ale také to, že jsou na rozdíl od Egypta v páru: „Shamash, these [figurine]s that

\footnotetext{
51 Borghouts 1978, 51-53.

52 Borghouts 1978, 42.

${ }^{53}$ Corpus of Mesopotamian Anti-Witchcraft Rituals online: http://oracc.museum. upenn.edu/cmawro/corpus (31. 5. 2015).
} 
I am holding up in the presence of your great divinity - Shamash, you know (them), I do not know (them): (these are) the figurines of the male and female who are furious with me, the figurines of my warlock and witch who have performed evil against me, who have buried carved images of me in a grave, .... (who) have sent me (witchcraft) by means of any evil... "Po popisu činu čaroděje a čarodějnici následuje důležitý motiv „vrácení kletby“: „Shamash, [at] your supreme command, which cannot be changed, I burn them before you, I turn their schemes back upon them."

Jestliže cílem těchto zaríkání je „odvráceni“ zla a „vrácení“ ho zpátky, cílem proklínacích textu je úplné zničení nepř́tele. Zatímco v Mezopotámii se texty proklínací povahy vztahují jenom na démony a zlé duchy mrtvých, v Egyptě, jak již víme, hlavně na cizí státy a jejich vládce. Archetypickou situací v tomto prípadě je vítězství Re nad Apopem, rádu Maat nad chaosem, které se stává jakýmsi precedentem (anglicky „divine case precedent”) pro fungování proklínacích rituálů. Původně tato epizoda představovala pouze hlavu z Knihy Mrtvých, ale v Pozdní době bylo sestavené celé dílo s názvem „Kniha Svržení Apopa” (anglicky "The Book of Overthrowing Apop”), která se stala precedentem pro další rituály na všech úrovních, od chrámových po soukromé ${ }^{54} \vee$ Řecko-Římské době se tento archetyp široce používal v soukromé destruktivní magii, jejiž cílem bylo někomu uškodit. Obět byla ztotožňována s Apopem, a velmi často pod textem rituálu následuje instrukce pronášet toto zaříkání nad voskovou figurkou Apopa. ${ }^{55}$ Množství dochovaných textů poukazuje na skutečnost, že se to stalo mezi Egyptany běžnou praxí. Čteme, napríklad, že „toto zaříkání mưže být použito proti všem nepř́telům, mužưm a ženám, jichž se tvoje srdce obává." Jiné zaříkání uvádí: „Jestliže toto zaříkání bude proneseno proti jakémukoliv nepř́teli N, stane se mu něco zlého během 7 dní. ${ }^{" 56}$ Tak se jednoduchý model: obět - čaroděj - kněz rozšiřuje do sakrální, kosmické úrovně, kde kněz představuje boha Re, nepř́tel - Apopa,

\footnotetext{
54 Pinch 2006, 86-88.

55 Jacq 1985, 95-99.

56 Kriech Ritner 2008, 13, 190.
} 
a pacient či obět' - Egypt, a vlastně i celý uspořádaný svět, který musí být zachráněn. Krátce si to můžeme shrnout do následující tabulky, kde přehledně uvidíme, že rozdíly mezi Egyptem a Mezopotámií nejsou tak dramatické, jak by se mohlo zdát. Na úrovni sakrální božský řád vždy bojuje s chaosem, zatímco na úrovni profánní se sociální raád potýká s neřádem. I přestože v mezopotamských proti-čarodějnických rituálech není explicitně vyjádřeno, kdo představuje řád a kdo chaos, najít podobné archetypy v mezopotamské mytologii není těžké:

\begin{tabular}{|c|c|c|c|}
\hline \multicolumn{2}{|c|}{ Na úrovni ... } & EGYPT & MEZOPOTÁMIE \\
\hline $\begin{array}{l}\text { sakrální } \\
\text { (kosmos) }\end{array}$ & $\begin{array}{c}\text { Božský řád } \\
\text { X } \\
\text { chaos }\end{array}$ & $\begin{array}{l}\text { MAAT X chaos } \\
\text { Re X Apop }\end{array}$ & $\begin{array}{l}\text { ME (parșu) X chaos } \\
\text { Marduk X Tiamat } \\
\text { Bůh bouře X had }\end{array}$ \\
\hline $\begin{array}{l}\text { profánní } \\
\text { (člověk) }\end{array}$ & $\begin{array}{c}\text { sociální řád } \\
\text { X } \\
\text { neřád }\end{array}$ & $\begin{array}{l}\text { Egypt X jeho nepřátelé } \\
\text { Člověk X nemoc (= síly } \\
\text { chaosu) }\end{array}$ & $\begin{array}{l}\text { āšipu X čarodějnice } \\
\text { Člověk X nemoc (= síly } \\
\text { chaosu / čarodějnictví) }\end{array}$ \\
\hline
\end{tabular}

Hodně zajímavé je sledovat vývoj tohoto typu rituálu, protože v těchto dvou kulturách probíhal v opačném směru: v Egyptě - od sakrálního k profánnímu, od Knihy Mrtvých k soukromým rituálům; zatímco v Mezopotámii naopak, od profánního k sakrálnímu, od vesnických rituálů proti čarodějnicím až ke standardní verzi Maqlu, začleněné do královského asyrského rituálu Bīt rimki, kde čarodějnice už představuje kosmické zlo a síly chaosu. ${ }^{57}$

Na závěr se ale musíme vrátit k magickým figurkám a říct několik slov o způsobech jejich zničení během rituálů. Tento proces, jak v Egyptě, tak v Mezopotámii, se tradičně dělil na dvě etapy: za prvé, poní̌ení, a za druhé, zničení samotné. Způsobů ponížení existovalo velké množství - zdá se, že záleželo jen na fantazii kněžstva. Nejčastějšími však byly: bodnutí a propíchnutí figurek, plivání, šlapání58; v Mezopotámii také umývání rukou či celého těla nad figurkami čarodějů (doloženo z rituálu Bīt rimki) a polévání figurek rybím tukem nebo dalšími nepř́ijemnými

\footnotetext{
${ }^{57}$ Abusch 2002, 113-162.

${ }^{58}$ Kriech Ritner 2008, 73-171; Jacq 1985, 98-102.
} 
substancemi. ${ }^{59}$ Následující etapa zničení se v Egyptě a Mezopotámii liší. V Egyptě figurky nepřátel mohly být přibity ke zdi pevnosti, podobně jako váleční zajatci (což se žrejmě stávalo v núbijské Mirgisse) ${ }^{60}$, ale úplně nejčastěji byly upalovány a poté pohřbívány - z egyptského pohledu to bylo nezbytné pro zničení těla a duše. V Mezopotámii figurka čarodějnice mohla být bud' upálena, což znamenalo definitivní smrt, a nebo pohřbena, což znamenalo možnost vstoupit do podsvětí, a skutečně bylo jakýmsi „vyhnáním do podsvětí." Upálení se při tom jasně vztahuje na slunečního boha Šamaše, a vyhnání do podsvětí na boha Nergala. Podle badatelů je „vyhnání“ rozhodně pozdější inovací, a není úplně jasné, proč čarodějnici byla tahle možnost vủbec daná: možná zkrátka proto, aby mohla pořád zůstat součástí organizovaného kosmu. ${ }^{61}$

Na začátku článku jsme se pokusili rozdělit magii na „bílou” (tzv. ochrannou) a „černou“ (tzv. destruktivní), ale postupně jsme si uvědomili, že striktní hranice v egyptské a mezopotamské magii neexistují. Úplně stejné metody a magické techniky jsou používány k dosažení různých, často i naprosto opačných cílů. Nezáleží však jen na cílu samotném, ale hlavně na úhlu pohledu. Magická figurka je v tomto ohledu pouhým prostředkem k dosažení cíle: sama o sobě neznamená nic. Jsou to text zaříkání a správně provedený rituál, co ji mohou přeměnit v mocnou zbraň, která se ocitne na straně bílé či černé magie.

\footnotetext{
59 Abusch - Schwemer 2011, 23.

60 Pinch 2006, 93-94.

61 Abusch 2002, 219-247.
} 


\section{Literatura}

Abusch, Tzvi 2002: Mesopotamian witchcraft. Toward a history and understanding of Babylonian Witchcraft beliefs and literature [Ancient Magic and Divination V], Leiden - Boston - Köln: Brill - Styx. Abusch, Tzvi - Schwemer, Daniel 2011: Corpus of Mesopotamian AntiWitchcraft Rituals, Leiden: Brill.

Online: http://www.cmawro.altorientalistik.uni-wuerzburg.de/startseite/ (31. 5. 2015)

Borghouts, J.F. 1978: Ancient Egyptian Magical Texts, Leiden: Brill.

Farber, Walter 2000: „Witchcraft, Magic, and Divination in Ancient Mesopotamia", in: Jack M. Sasson (ed.), Civilizations of the Ancient Near East, vol. III\&IV, Peabody: Hendrickson Publishers.

Jacq, Christian 1985: Egyptian Magic, Wiltshire: Aris \& Phillips - Chicago, IL: Bolchazy-Carducci.

Kriech Ritner, Robert 2008: "The Mechanics of Ancient Egyptian Magical Practice", in: Thomas A. Holland (ed.), Studies in Ancient Oriental Civilization No.54, Chicago - Illinois.

Online: https://oi.uchicago.edu/sites/oi.uchicago.edu/files/uploads/ shared/docs/saoc54_4th.pdf (31. 5. 2015)

Pinch, Geraldine 2006: Magic in Ancient Egypt, Austin: University of Texas Press.

Redford, Susan 2002: The harem conspiracy: the murder of Ramesses III, Northern Illinois University Press. 


\section{Jana Jiroušková}

\section{"Jen mrtvá ryba pluje po proudu“ Zvî́recí tématika $v$ africké tradici}

„Mưj život je jednotvárný. Honím slepice a lidé honí mne. Všechny slepice jsou si navzájem podobné a také lidi jsou si podobní. Trochu se proto nudím. Ale když si mě ochočišs, bude mưj život jakoby prozářen sluncem. Poznám zvuk kroků, který bude jiný než všechny ostatní. Ostatní kroky mě zahánějí pod zem. Ale tvưj krok mě jako hudba vyláká z doupěte... Bude opravdu nádherné, až si mě ochočǐš. "

Antoine de Saint-Exupéry

Být ochočený stejně jako liška z Malého prince Antoine de Saint Exupéry znamená z hlediska zvir̃ete uzavřít výhodné partnerství s člověkem. Některá zvir̃ata se k člověku přidala v průběhu tisíciletí jen kvưli tomu, že blízkost lidských obydlí poskytovala snadnou obživu. Jiná si člověk vybral sám, nebot' mu přinášela nějaký druh prospěchu (maso, mléko, vlnu nebo ovládala činnosti, ve kterých člověk neměl přiliš velké šance). Život v subsaharské Africe je dodnes závislý na mnoha zvir̃atech a to jak domácích tak divokých. Zvir̃ata jsou nejen nezbytná z hlediska potravin, ale jsou součástí mytologie a lidových vyprávění. Zvir̃ata podle mnoha legend naučila člověka pěstovat různé rostliny, rovněž mu pomáhají při komunikaci s duchy předků, některá jsou symbolem moci a společenského postavení. Hlavní roli v ústní lidové slovesnosti však nehrají zvir̃ata velkých rozměrů a síly (jako např. slon či žirafa), ale stvoření docela maličká jako např. pavouk nebo zajíc. Těmto v celku nepatrným stvořením je díky vyprávěním přisuzována řada důležitých vlastností jako např. chytrost a mazanost. 


\section{Antilopa}

Antilopa je oblíbeným zvî̃etem v západní Africe, zejména u zemědělských společností. Podle řady legend ze západní Afriky polobůh v podobě antilopy naučil prapředky dnešních Afričanů zemědělské techniky. K nejznámějším patří př́běh od malijských Bambarů, kteří používají při svých rituálních slavnostech několik typů antilopích masek (seguni, čivara).

Původ masky seguni vysvětluje jeden z bambarských mýtů následujícím způsobem. Za dávných časů žil na zemi Čivara, polobůh a poločlověk, který naučil lidi obdělávat půdu. Lidé však byli nevděční, jakmile sklidili první větší úrodu, prestali poloboha uctívat. Čivara se velmi rozhněval a vykopal si hrob vlastní hlavou, která se podle bambarských představ podobala ostři motyky, a sám se v něm pohřbil. Na pamět Čivary lidé pak začali zhotovovat masky a slavit tancem každoroční svátek setí. ${ }^{22}$ Tato legenda svědčí 0 tom, že dnešní Bambarové vidí v maskách seguni stylizované vyobrazení motyky, kdežto jejich název a forma jasně dokazují, že základem je druh místní antilopy. Ztráta pưvodního obsahu vedla k tomu, že maska predstavující antilopu čivara se změnila v stylizovanou masku seguni, zbavenou určitého smyslu.

$\checkmark$ mýtu o prvních zemědělcích má maska roli prostředníka mezi Bohem a člověkem. Je nástrojem udobření. Člověk vytvárí masku jako poděkování za úrodu a přislib budoucí úrody. Nemůže však vytvořit masku podle vlastních představ. Protože maska podle jeho představ by v sobě neskrývala čitelné sdělovací znaky pro Boha, který má zaručit dobrou úrodu a tím i dobrou prosperitu celé společnosti i v následujících letech.

\section{Pavouk}

K dalším velmi oblíbeným zvir̃atům patří v západní Africe pavouk. Některé druhy pavoukủ zijící v této oblasti obývají zemní nory. Lidé proto veří, že pavouci se mohou setkávat a hovořit s duchy zemřelých

62 Rupert 2005, 18-22. 
předků. Jejich pověst však není bez chyby. Např. u Akanů v Ghaně věří, že pavouk má sice zvláštní moc, ale není príliš čestný a když je to nutné dokáže okrást i vlastní rodinu. Podle jedné legendy měl pavouk Ananse početnou rodinu. Rodina obdelávala velké pole jamů. Jeden rok byla úroda nízká. Ananse měl jamy ve velké oblibě a bál se, že mu je jeho rodina sní. Rozhodl se, že své nejbližší príbuzné předběhne. Každou noc se vydával na pole a snědl tolik jamů, kolik jen mohl. Jeho žena se pak ráno divila, kam mizí každou noc úroda. Rozhodla se tuto situaci vyřešit s místním čarodějem. Podle jeho rady vyrobila velkou dřevěnou sochu, potřela ji lepem a v noci ji umístila na pole. Nic o tom neřekla Anansemu. Ananse stejně jako každou noc vyrazil na pole a jedl jamy. Najednou si všiml, že na okraji jeho pole někdo stojí, bě̌̌el tam a vetřelci nadával. Dokonce do něj začal bušit a kopal a tak se prilepil na lep. Ráno ho objevila jeho žena. Velmi se za svého muže styděla a raději se s celou rodinou přestěhovala pod zem, aby se nemusela setkávat s ostatními zvir̃aty. ${ }^{63}$

V jiné legendě pavouk dokonce prokazuje i známky určité naivity až hlouposti. Kdysi se pavouk Ananse rozhodl stát se nejmoudřejším zvî̃etem na světě. Obstaral si velký hliněný hrnec s poklicí, ve kterém chtěl shromáždit všechnu moudrost světa. Chodil od jednoho zvir̃ete ke druhému a žádal je, aby řekli něco opravdu moudrého. Když zvir̃ata něco moudrého řekla, naklonil jim před ústa hrnec a pak jej rychle zav̌̌el, aby moudro neuteklo. Chodil mnoho dnů po celém světě, až již nebylo na zemi zvir̃e, které by mu nic ně̌eklo. Ananse byl unavený a chtěl se chvilku vyspat. Měl však strach, že mu někdo hrnec s moudrostí ukradne a tak se rozhodl jej vytáhnout do koruny vysokého stromu. Ovázal hrnec provazem, který přehodil přes větev a tahal hrnec pomalu nahoru. Hrnec byl těžký a lano staré. Najednou se lano přetrhlo, hrnec spadl na zem, rozlétl se na tisíce kousků a Ananse zjistit, že v něm není vůbec nic. A tak byl Ananse stejně hloupý jako na začátku, když začínal s chytáním moudrosti. ${ }^{64}$

63 Roberts 1994, 91-95.

64 Roberts 1994, 33-35. 


\section{Chameleon}

Chameleon díky své schopnosti měnit barvu a prizzůsobit se tak prostředí, ve kterém se vyskytuje, neunikl pozornosti domorodého obyvatelstva. V západní Africe je spojován se smrtí a netěší se velké oblibě. Na některých místech v Kamerunu po něm dokonce lidé hází kameny, aby jej odehnali, nebot je poslem smrti. Podle jedné kamerunské legendy žili lidé v minulosti velmi štastně, neznali nemoci a neumírali. Tento způsob života se jim velmi líbil, obávali se však, že to tak nebude věčně. Ptali se nejmoudřejších lidí i zvî̃at, ale nikdo nedokázal odpovědět a tak nakonec vyslali dva posly k Bohu, aby jim zjistili, jak bude jejich život probíhat dál. Jeden z poslů byl pes, pokud by se vrátil jako první, přinesl by zprávu o tom, že lidé nepoznají nemoci ani stáŕí a budou nesmrtelní. Druhým poslem byl chameleon. Pokud by se chameleon vrátil od Boha první, lidé poznají rủzné nemoci a stárí a budou smrtelní. Pes je mnohem rychlejší než chameleon a tak se lidé těšili na príznivou odpověd" od Boha. Oba poslové dorazili k Bohu a ten je s potvrzením jejich zpráv poslal zpět k lidem. Pes běžel rychle a na začátku nebylo pochyb, že doběhne jako první. Cestou však uviděl velkou hromadu kostí a masa. Neodolal a všechno snědl. Spořádat tak ohromné množství jídla ho zcela unavilo a usnul. Spal dlouho a tvrdě. Chameleon ho mezitím dohonil a do vesnice se dostavil jako první. Když se pes probudil, lidé již znali zprávu od chameleona. Od těch dob není chameleon ve vesnicích vítaný a je zaháněn házením kamenů. ${ }^{65}$

\section{Želva}

Želva je považována za jedno z nejmoudřejších zvir̃at. Není moudrá díky studiu, ale vysokému věku, kterého se může dožít. Často je žádána o radu v situacích, které se staly v minulosti a byly úspěšně vyřešeny. Ve východoafrické mytologii se želva často nazývá jménem Mzee. Je to svahilský výraz pro starý. $V$ jižní Africe věří, že praželva jménem Fudukazi dala barvy všem zvir̃atům. V nigerijských vyprávěních je želva mazaným šejdî̃em. ${ }^{66}$

\footnotetext{
65 Blauer 1999, 112-114.

66 Blauer 1999, 99.
} 


\section{Hyena}

Hyena je často charakterizována jako zvî̃e vychytralé až Istivé, ale ve většině príběhů se její snahy míjí účinkem a sama odchází z boje jako poražená. Zdrojem špatné pověsti a tedy i malé oblíbenosti hyeny u domorodých společností je její záliba pojídat mršiny. Ne vždy má tak špatnou pověst. Např. u etnika Tabwa ve východní Africe je hyena zvíře, které přineslo na zemi slunce. V Tanzanii je však pověst hyen stejně ošklivá jako v západní Africe, čarodějnice zde podle lidových vyprávění používají hyeny místo koní jako dopravní prostředky. Dokonce zde věří, že když se narodí dítě v noci, kdy je slyšet chechtot hyen, je velmi pravděpodobné, že z novorozence vyroste zloděj. Vztah k hyenám je velmi variabilní. Rovněž ve východní Africe existuje pověra, že když má dítě u sebe kousek hyeního trusu, bude brzy chodit a tak se vyrábějí amulety s hyením trusem pro děti. U etnika Mansoa se věři, že se může člověk proměnit $v$ hyenu. Do lidské podoby se nemůže vrátit, pokud $v$ hyení podobě zabil zvir̃e nebo člověka.

\section{Závěr}

V tradiční africké mytologii se vyskytuje řada zvir̃ecích hrdinů. Ve větší oblibě jsou zvî̃ata slabá či malá (jako je např. pavouk, zajíc, chameleon). Role jednotlivých zvir̃at se regionálně liší. Např. velice populární zajíc, který je v západní Africe symbolem mazanosti, se v oblasti řeky Kongo vůbec ve vyprávěních nevyskytuje a jeho roli zručného a mazaného hrdiny přejímají různé druhy menších antilop. V jižní Africe u Khoisanů je zajíc naopak považován ze zcela hloupého. Roli chytráka zde hraje většinou fretka.

Velká zvir̃ata jako je slon nebo lev jsou pouze symbolem hrubé síly. 


\section{Literatura}

Bacquart, Jean-Baptiste 1998: The Tribal Arts of Africa, London.

Bargma, Ivan 2008: Afrika. Der schwarze Kontinent, Berlin.

Blauer, Ettagale 1999: African Elegance, New York.

Hahner-Herzog, Iris - Kecskesi, Maria - Vajda, Lazlo 2010: African Masks: From the Barbier-Mueller Collection, London.

Fall, N’Goné - Pivin, Jean Loup 2002: An Anthropology of African Art, New York.

Kollos, Hans-Joachim 1988: Africa. Art and Culture, New York.

Meyer, Laure 2001: Black Africa, Paris.

Poynor, Robin 1995: African Art at the Museum, Gainsville.

Roberts, Allen 1994: Animals in African Art, München.

Rupert, Jean 2005: The African Mask, Lincoln.

Trojanová, Alena 1976: Umenie čiernej Afriky, Bratislava.

Willet, Frank 1993: African Art, New York. 


\section{Jiří Matela}

\section{Prostorová konceptualizace UČI - SOTO a její projevy $v$ japonském jazyce}

\section{1 Úvod ${ }^{67}$}

Prostorová konceptualizace a její projevy v systému jazyka jsou předmětem řady studií, především v rámci tzv. kognitivní lingvistiky (např. Sinha a Jensen de López, 2000; Talmy, 2007). Mnohé z nich se zabývají konceptuálními schématy, jež bývají vyjadřovány pomocí předložek jako in, on, before a další v angličtině či „ „v“, „za”, , „před”, „do” a další v češtině. Tradiční modulární pojetí jazyka a mysli disponuje omezenými explanačním potenciálem, pokud jde o prostorovou konceptualizaci, nebot' nepředpokládá př́mé vztahy mezi kognicí v mimojazykovém kontextu a jazykovým systémem. Do značné míry to platí i pro oblast japonských studií. Přestože prací, které usouvztažňují jevy jazykové s jevy kulturně-sociálními a buduji „celostní obraz japonského vnímání světa přibývá, rozvoj moderních vědních přístupů, jež se oproštují od ideologicky zatíženého diskursu nihondžinron („teorií japonskosti“), je stále v počátcích.

Tento příspěvek si klade za cíl přibližit prostorovou konceptualizaci v dichotomii „vnitřního" a „vnějšího" tak, jak se projevuje v systému moderního japonského jazyka. K dichotomii vnitřního a vnějšího se v japonském kontextu nejčastěji odkazuje skrze pojmy UČl a SOTO. Přestože struktura těchto pojmů má výrazný kulturně motivovaný

${ }_{67}$ Pro přepis japonských výrazů je v celém textu použita česká transkripce, japonská jména jsou řazena dle českého úzu. Všechny překlady i př́ílady mé vlastní. 
charakter, je nutno zde poukázat i na jiné než kulturní zdroje. K tomu se nabízi aparát moderních kognitivních věd, jenž propojuje fyziologickou, neurobiologickou a psychologickou rovinu lidské existence se sociokulturními faktory a umožňuje tak uchopit jak obecné (univerzální) rysy člověka jako biologického druhu, tak i bohatou kulturní různorodost jednotlivých lidských společenství. Japonský jazyk se potom jeví jako ideální prostředek nahližení specifik japonské kulturní konceptualizace v porovnání s kulturami a jazykovými systémy odlišnými.

V následující části představím UČı a SOTO jako koncepty, jež se objevují ve studiích nejazykových, a doplním je o nástin lexikálních obsahů výrazů uči a soto v japonštině. Následně nastíním východiska pro prístup k jazykové konceptualizaci z perspektivy kognitivní lingvistiky. Stěžejní částí textu pak bude predstavení vybraných jevů v japonském jazyce, jež se nabízejí pro analýzu skrze výše zmíněnou dichotomii. Konkrétní manifestace konceptů UČl a SOTO ve struktuře japonštiny jsou voleny tak, aby ilustrovaly aplikaci prostorové konceptualizace v různých rovinách jazykového systému. Současně je mojí snahou zasadit prostorovou konceptualizaci do kontextu gramatické osoby, což má v důsledku přispět k zefektivnění výuky japonštiny jako cizího jazyka.

\section{Pojmy UČl a SOTO v kontextu japonské kultury}

S pojmy UČl a SOTO se nejčastěji setkáváme při popisu japonských sociálních vztahů a chování ve společenských institucích, kde jsou tyto pojmy většinou dávány do souvislostí s dalšími sociokulturními koncepty, jako např. HONNE, TATEMAE, URA, OMOTE atd. ${ }^{68}$ Zmíněnými institucemi rozumíme rodinu, školu, firmu či jiné pracovní prostředí, zájmové skupiny apod. Sugimoto 2002 se k pojmům uči a soto vyjadřuje následovně:

„(...) V odkazování na príslušnost jedince k určité skupině se tato dichotomie užívá pro odlišení členů a ne-členů dané skupiny. Zaměstnanci firem při rozhovorech s lidmi z vnějšku často o své firmě hovoří jako o uči a načrtávají tak hranici mezi "my” a „oni“. Člověk

${ }^{68}$ Viz např. Hendry, 1995. 
nemůže otevřeně rozebírat citlivé záležitosti v soto, ale může př́imočaře narušit důvěrnost $v$ situacích uči. V kontextu mezilidské interakce představují aspekty soto vnější povrchové projevy, zatímco prvky uči odkazují k nejniternější podstatě a skutečné povaze daného člověka." ${ }^{69}$

Takto popsaná konceptualizace sociálního prostoru přirozeně není něčím výlučně japonským. S mnoha různými př́iklady vnímání konceptuální hranice mezi „interním” a „externím” (případně „soukromým” a „veřejným”) se Ize setkat ve většině běžně známých kultur. Konkrétní konfigurace může být kulturně specifická, samotná dichotomie však vykazuje znaky kulturní univerzálie. Pro japonské prostředí je potom příznačné především užívání označení uči, soto. To má přímou souvislost s lexikálními jednotkami, tj. s výrazy uči a soto a jejich lexikálním obsahem.

Lexikální vyšetřování výrazů uči a soto skrze běžné japonské slovníky naznačuje, že oba výrazy sice tvoří dichotomii (tj. Ize je vnímat jako součásti téhož konceptuálního rámce), avšak současně vykazují jistou asymetrii. Níže předkládám nástin lexikálních významů výrazů uči a soto dle běžných slovníků japonského jazyka:

vnitřek; uvniť̌ (určitého prostoru, např. pokoje, budovy)
něčípocity [myšlenky]; něčí opravdové cítění; zevně nevyjádřené nitro
my; naše [moje] společnost [firma]
v (určitém množství); část (určité třídy věcí); během (časově daného
rozmezí)
dům; něčí dưm; můj [náš] dům; domov; domácnost; rodina; [něčí]
rodina; něčímanžel [manželka]
vně, mimo
vnější (prostor, např. vnější prostor budovy)
jiné místo; někde jinde; směr či místo vzdálené centru
externí (např. vyjádření emocí)

$\overline{69}$ Sugimoto 2002, 28-29 
Z výčtu je patrné, že výraz uči disponuje bohatším lexikálním obsahem než výraz soto. Jeho extenze $k$ významům <dům> je také doprovázena extenzí grafickou - v tomto významu mưže být uči zapsán pomocí čínského znaku 家, oproti primárnímu zápisu 内..$^{70} \mathrm{U}$ pojmu soto, jenž je standardně zapisován znakem 外, kromě zápisu pomocí fonematických abeced podobná grafická extenze nefiguruje. Sémantický záběr výrazu uči je prímo vázán na sociokulturní zkušenost. Zkušenost s koncepty, jež se týkají „interního prostoru“, je přirozeně konkrétnější a bohatší, než zkušenost s prostorem vnějším. I proto má výraz uči ve srovnání s výrazem soto širší a bohatší obsahový plán.

Sociokulturní zkušenost sice lze pokládat za zdroj sémantického obsahu výrazů uči a soto, nevysvětluje však motivace pro vznik konceptuálních kategorií (v dané dichotomii) na bazální abstraktní rovině. Sociologická či kulturně antropologická literatura tedy popisuje japonské sociální a kulturní instituce v pojmech UČl a SOTO, nepředkládá však východiska pro primární existenci těchto pojmů v konceptuálním systému Japonců. $\checkmark$ tomto ohledu je třeba se obrátit k jiným teoreticko-metodologickým zdrojům. Jako velmi funkční se zde nabízí přístupy moderní kognitivní lingvistiky, coby součásti širšího spektra tzv. kognitivních věd.

\section{Jazyk jako odraz konceptualizace}

Kognitivní prístupy ke zkoumání jazyka představují jednu ze součástí širokého spektra moderních kognitivních věd, jejichž společným cílem je zkoumání fungování, podstaty a důsledků mechanismů lidského myšlení, vnímání a chápání světa v jeho celistvosti. K člověku přistupuje jako k objektu biologickému, fyziologickému, ale současně také sociálnímu a kulturnímu. Kognitivní vědy pak kromě lingvistiky přirozeně sdružují genetiku, biologii, neurovědy, psychologii, kybernetiku, filozofii, sociologii, antropologii a další disciplíny, jež se pokoušejí uchopit lidskou kognici skrze vzájemně kompatibilní teoreticko-metodologická východiska. ${ }^{71}$ Takto pojímaná kognitivní lingvistika se řadí k jazykovědným

70 Ve významu <vnitřek> se také vyskytuje grafický zápis znakem 中.

71 Z rozsáhlého spektra literatury na téma moderních kognitivních věd a jejich celostního rámcování odkazuji např. k Lakoff a Johnson, 1999 či Feldman, 2006. 
přistupům „funkcionalistickým”, v kontrastu k prístupům „formalistickým" (mezi které bývají řazeny např. generativisticky orientované prístupy), a toto začlenění s sebou přináší nemalé důsledky.

Zde je tedy namístě představit některá základní východiska kognitivní lingvistiky, které z tohoto prístupu činí vhodný aparát pro uchopení prostorové konceptualizace v japonském jazyce.

Jednou ze základních charakteristik kognitivní lingvistiky je její „anti-modulární" postoj k lidskému jazyku a mysli. Mysl není nahlížena jako komplex samostatných kognitivních modulů, nýbrž jako jev "gestaltový". Jazyk, jako neoddělitelná součást lidského kognitivního systému, pak rovněž není pojímán jako samostatný modul (v chomskyánském či pinkerovském smyslu), zdůrazňuje se jeho propojení do širšího celku mentálních, kognitivních a biologických funkcí člověka. Funkcionalistický postoj se pak projevuje v předpokladu, že podoba jazykového systému je dána funkcemi, jež tento systém plní. Je to právě "anti-modularismus", co umožňuje (a současně je předpokladem) zařazení kognitivní lingvistiky do komplexu kognitivních věd. Současně jí to také umožňuje interdisciplinárně využívat poznatků různých disciplín, jež tento komplex spoluutváŕí.

Jazykový systém jako součást širšího systému kognitivního předpokládá sdílení principů a mechanismů S "nejazykovými” kognitivními funkcemi (jako je např. kategorizace, pozornost, pamět apod.). Kognice jako taková má přitom „vtělesněnou“ podstatu, tj. je postavena na fyziologických strukturách lidského těla. Konceptualizace, jako jeden z kognitivních mechanismů, má pak nevyhnutelně zkušenostní základ. I prostorová konceptualizace je tedy výsledkem interakce lidské tělesnosti s prostředím, v němž se člověk nachází. Univerzální rozměr lidské konceptualizace je dán univerzálností biologických predispozic člověka jako živočišného druhu, stejně jako univerzáliemi environmentálními.

Specifické rozměry konceptualizace jsou pak způsobeny specifiky prostředí, mj. společensko-kulturních, v nichž je člověk vystaven širokému spektru zkušeností. Skutečnost, že jazykový systém sdílí charakteristiky širšího konceptuálního systému člověka, nabízí príistup 
i k takovým prvkům lidské kognice, jež by jinak byly jen obtižně uchopitelné. Kognitivní lingvistika tedy ve své snaze odhalit a vysvětlit obecné mechanismy a jevy lidské kognice vychází z předpokladu, že právě jazykový systém jako objekt zkoumání může sloužit jako odraz (a do jisté míry reprezentace) kognitivního systému.

\subsection{Konceptuální dichotomie VNITŘNÍ - VNĚJŠí a Teorie představových schémat}

Tak jako je kognitivně orientovaná jazykověda součástí širokého spektra kognitivních věd, je sama kognitivní lingvistika především souhrnem různorodé plejády teorií, jež sdružují základní teoreticko-metodologická východiska nastíněná výše. Mezi tyto teorie Ize zařadit Teorii konceptuální metafory (Conceptual Metaphor Theory), Teorii mentálních prostorů (Mental Spaces Theory) a pojmové integrace (blending), různé varianty konstrukční gramatiky (construction grammar) a řadu dalších. K nástinu motivací pro vznik konceptuální dichotomie VNITŘNÍ - VNĚJŠí se pak nabízí aparát tzv. Teorie představových schémat (Image Schema Theory).

Představová schémata jsou charakterizována jako konceptuální reprezentace, jež vznikají abstrakcí opakujících se vzorců naší každodenní konkrétní zkušenosti s prostředím, v němž se nacházíme. Utvářejí se primárně ze smyslové a percepční zkušenosti. (Evans, 2007) Př́ikladem takového představového schématu může být schéma vertikálnosti (UP-DOWN image schema), jež je motivováno naší existencí ve fyzikálním prostředí zatíženém gravitací.

Představové schéma OBSAHOVÁNÍ má strukturu tvơ̌enou třemi základními prvky: VNĚ, UVNITŘ a PŘEDĚL. Jeho vznik bývá motivován různorodou zkušeností v nejranějších stádích života jedince. Základem může být pobyt v ohraničeném prostoru, interakce s predměty, jež fungují jako nádoby, ale také zkušenost s vlastním fyzickým tělem, jež má samo o sobě charakteristiky "nádoby".

Právě představové schéma OBSAHOVÁNí Ize označit za hlavní zdroj konceptuální dichotomie UČl - SOTO. Detailní struktura pojmů UČl a SOTO v konceptuálním systému Japonců je potom príirozeně 
specifikována sociokulturními faktory japonského společenského prostředí, japonská sociokulturní specifika tedy motivují specifické charakteristiky daných pojmů. Jinak řečeno, přestože univerzálnost předpokladů pro vznik představového schématu OBSAHOVÁNÍ zaručuje obecnou existenci vnímání opozice vnějšku a vnitřku u všech lidí bez ohledu na kulturu, konkrétní konfigurace pojmů VNĚ a UVNITŘ v rámci konceptuálního systému každého jednotlivce bývá výrazně ovlivněna kulturními specifiky prostředí, v němž se dotyčný pohybuje. Sdílení kulturních normativů v rámci společenství pak umožňuje existenci prototypové konceptualizace v pojmech UČl a SOTO u členů japonské společnosti. Př́padné odchylky od daného kulturního prototypu Ize prissuzovat experienciální individuálnosti konkrétního člověka.

\section{Projevy dichotomie UČI - SOTO v japonském jazyce}

Jako samožejmé se jeví, že koncepty UČl a SOTO jsou základem lexikálního obsahu výrazů uči a soto, jak byly tyto představeny v části 2. Cílem tohoto příspěvku je však představit projevy této konceptuální dichotomie na různých rovinách systému japonského jazyka. Z perspektivy kognitivní lingvistiky, jak byla nastíněna v části 3, není překvapivé, že na tyto projevy lze vůbec narazit. Konceptualizace sociálního prostoru, jak ji popisuje sociologická či antropologická literatura, a struktura jazykového systému je vázána na jeden a tentýž provázaný a ucelený kognitivní systém. Presto je tato souvztažnost v odborné literatuře často přehlǐzena a charakteristika struktury japonského jazyka v pojmech UČl a SOTO bývá spiše výjimkou (např. Makino 1996). Nástin popisu japonštiny pomocí dichotomie UČla SOTO v následujícím výkladu bude průběžně konfrontován s pojetím kategorie "gramatické" osoby.

\subsection{Slovesa dávání a dostávání}

Japonština bývá klasifikována jako jazyk, jenž nevykazuje morfologickou shodu podmětu s prísudkem, tak jak ji známe z řady evropských jazyků. Kategorie osoby sémantického konatele se tedy v japonštině neváže na koncovku predikativu. Nabízi se však otázka, zda nemůže mít projevy jiné, především lexikální. To se týká především skupiny sloves 
dávání a dostávání (jap. džudžu dóši), tj. sloves ageru, sašiageru, jaru, kureru, kudasaru, morau a itadaku. Obsah těchto sloves je založen na schématu rámce přesunu objektu s přínakem benefice mezi předávajícím a recipientem. Slovesa morau a itadaku profilují jako podmět recipienta, tj. mají význam <dostat, získat, obdržet>, slovesa ageru, sašiageru, jaru, kureru a kudasaru profilují jako podmět predávajícího, tj. mají význam <dát, věnovat, udělit>. Slovesa utvárejí dichotomie \{morau - itadaku\}, \{ageru - sašiageru\}, \{kureru - kudasaru\}, v nichž druhý člen je príznakový z hlediska zdvořilosti (viz 4.2). Rozdíl v propozičním obsahu mezi slovesem morau a dvojicí ageru, kureru je rozdílem profilace recipient vs. predávající v roli podmětu. ${ }^{72}$ Je však nutno popsat rozdíl v propozičním obsahu mezi slovesy ageru a kureru.

(1) Purezento o ageta.

"Dal jsem ti/mu/jí/vám/jim dárek."

(2) Marie-san ni purezento o ageta ne.

"Dal jsi Marii dárek, že?"

(3) Jan-san wa Marie-san ni purezento o ageta. „Jan dal dárek Marii."

(4) Jan-san wa (wataši ni) purezento o kureta. "Jan mi/nám dal dárek."

(5) Jan-san wa čiči ni purezento o kureta. „Jan dal dárek mému otci."

Príklady (1) - (3) ilustruji, že sloveso ageru Ize použít v konstrukcích s podmětem v 1., 2. i 3. osobě. Tríprvkové pojetí kategorie osoby v konfiguraci dle účasti na komunikační situaci však nedokáže objasnit motivaci užití ageru vs. kureru. (3) i (4) vyjadřují shodně 3. osobu konatele (podmětu), (3) a (5) mají kromě 3. osoby konatele shodnou i 3. osobu recipienta.

Jako funkční se zde jeví nahradit hledisko 1., 2. a 3. osoby hlediskem UČl-SOTO. Slovesa ageru a kureru pak Ize charakterizovat

${ }_{72}$ Sloveso jaru zde ponechávám stranou, nebot má stejný propoziční obsah jako ageru. 
následovně: je-li recipient předávaného objektu konceptualizován jako prvek UČl, je slovesem dávání kureru; je-li recipient předávaného objektu konceptualizován jako prvek SOTO, je slovesem dávání ageru. Jak referent 1. osoby v príkladu (4) -<já>, tak i referent 3. osoby v príkladu (5) - <můj otec> jsou shodně konceptualizovány jako „osoba $U C{ }^{\prime \prime}$, a proto je slovesem dávání kureru. Referent 3. osoby v príkladu (3) - <Marie> je konceptualizován jako nenáležící do UČl (tedy spadá do SOTO), a proto je užito sloveso ageru. V případě, že by mluvčí konceptualizoval Marii jako součást svého UČl, užil by slovesa kureru.

Přesun beneficí obdařeného objektu se odehrává vždy mezi konceptuálním prostorem UČl a SOTO. Z toho důvodu nemůže být konatelem slovesa kureru referent „osoby UČl”:

(6) * Wataši wa Marie-san ni purezento o kureta.

(int. Já jsem dal dárek Marii.)

Konceptualizace sama o sobě však není fixní. Konceptuální určení hranice mezi UČla SOTO je tedy dynamickým procesem, který většinou probíhá online, tj. v okamžiku promluvy.

(7) Čiči wa purezento o kureta.

"Otec mi dal dárek."

Zatímco v príkladu (5) je referent výrazu čiči, <můj otec>, konceptualizován jako "osoba UČl” (tj. UČl = \{já, můj otec $\},$ SOTO = $\{$ Jan\}), v prílkladu (7) je stejný referent téhož výrazu konceptualizován jako „osoba SOTO" (tj. UČl = \{já\}, SOTO = \{můj otec $\}$ ). Tyto př́klady mj. dokládají, že užívání sloves dávání je v japonštině také vyjádřením tzv. konstruálu (construal), subjektivní konstruování objektivně nespecifikované situace volbou výrazového prostředku z několika možností. V případech jako (8) je volba slovesa podmíněna tím, kterého z rodičů vnímá mluvčí v okamžiku promluvy jako „bližšího“ prototypovému centru svého UČl (Makino 1996, 74):

(8) Čiči wa haha ni purezento o ageta/kureta. „Tatínek dal mamince dárek." 
Konfigurace sloves dávání a dostávání v rámci dichotomie UČl- SOTO $v$ japonštině platí i v situacích, kdy jsou tato slovesa užita ve funkci sloves pomocných, tj. je-li benefičním objektem určitá akce:

(9) Jan-san wa tecudatte kureta. "Jan mi/nám (*mu/*ji/*jim) pomohl."

(10) Jan-san wa tecudatte ageta. „Jan mu/íj/ijm (*mně/*nám) pomohl."

\subsection{Systém „zdvoriilostních“ výrazů}

Jak již bylo nastíněno v předchozí části, některá slovesa v japonštině tvoři paradigmata o jednom propozičním obsahu a různých výrazových (lexikálních či morfologických) obsazeních s príznaky interpersonální zdvoriilosti. Užití těchto príznakových tvarů (jap. keigo) je podmíněno sociopragmatickými faktory. Pro popis jejich systémové strukturace však opět Ize funkčně využít dichotomie „osob” UČla SOTO. Pro ilustraci volím niže príklady s paradigmatem slovesa iu, <ríci>: móšiageru (příznak [skromnost]), oššaru (přínnak [uctivost]). Komunikační situací je interakce firemní asistentky s externím návštěvníkem a s vlastním nadřízeným, tedy modelová situace, která vyžaduje keigo. ${ }^{73}$

(11) asistentka $\rightarrow$ host: Okjaku-sama ga oššatta kedo... „Jak jste řekl...." (dosl. 'Jak ctěný host ráčil říci...')

(12) asistentka $\rightarrow$ vedoucí: Bučó ga oššsatta kedo... „Jak jste (mi/nám) řekl, (pane vedoucí,)..."

(13) asistentka $\rightarrow$ vedoucí: Watakuši ga móšiageta kedo... „Jak jsem (Vám) řekla, (pane vedoucí,)..."

(14) asistentka $\rightarrow$ host: Bučó no Tanaka ga móśiageta kedo... „Jak (Vám) pan vedoucí Tanaka řekl..."

Užití skromného vs. uctivého výrazu není v moderní japonštině vázáno na objektivizované vlastnosti referentu, jenž je konatelem akce, nýbrž je předmětem dynamického konstruálu, skrze nějž mluvčí

73 Šipky naznačují směřování vípovědi na adresáta. 
konceptualizuje konatele interpersonální interakce bud' v doméně UČl (pro skromný výraz), nebo v doméně SOTO (pro uctivý výraz).

$\checkmark$ príkladech (11) a (12) je konatel (host a vedoucí) asistentkou konceptualizován jako součást relativního SOTO. V př́kladu (13) konceptualizuje asistentka sebe jako UČl a vedoucího jako vǔči sobě SOTO. V interakci s hostem ve (14) však hranici mezi oběma doménami konstruuje mezi vlastní firmou (UČl) a externím návštěvníkem (SOTO). Vedoucí je v takovém prípadě konceptualizován jako součást UČl a tedy jako referent konatele akce vyjádřené slovesem s príznakem skromnosti.

I v prípadě těchto tzv. „Zdvoriilostních“ výrazů platí, že pro volbu výrazového prostředku není určující 1., 2. či 3. osoba z hlediska účasti na komunikační situaci, nýbrž konceptualizace skrze dichotomii UČl-SOTO.

\subsection{Systém demonstrativ}

Systém demonstrativních výrazů (jap. šidži taikel) v japonštině představuje skupinu paradigmat na základě gramaticko-lexikální tř́dy a deiktického obsahu. Z hlediska gramaticko-lexikální třídy sem spadají výrazy jako koko <tady>, kore <toto> (substantivum), kono <tento> (atributivum), aj. Z hlediska deiktického obsahu tvoří výrazy v základu tři paradigmata se specifickým iniciálním morfémem: ko- (např. kore, kono...), so- (např. sore, sono...), a- (napr.. are, ano...). Tato trojí distribuce bývá někdy klasifikována pomocí tríčlenné kategorie: PROXIMÁLNÍ (ko-), MEDIÁLNÍ (so-), DISTÁLNí (a-), z hlediska relativní vzdálenosti referentu od mluvčího. I tato skupina výrazů však primárně představuje objekt subjektivního konstruálu mluvčího, jenž na rưzné úrovni abstrakce a v různých textových funkcích nabývá konfigurací, jež jsou pro objektivistické ukotvení problematické.

Analýzu strukturace japonských demonstrativ skrze dichotomii UČl - SOTO Ize provést následujícím způsobem. V prvním kroku vzniká opozice $U C \check{l} l=\{k o k o, k o r e, k o n o \ldots\}$ vs. SOTO $=\{$ soko, asoko, sore, are, sono, ano...\}. V druhém kroku je pak odděleno paradigma sood paradigmatu a-. K tomu dochází díky kognitivní projekci empatie 
S adresátem. ${ }^{74}$ Trojice paradigmat má pak ve výsledku následující strukturaci:

$$
\begin{aligned}
& \text { ko- = UČl mluvčího } \\
& \text { so- = UČl adresáta (SOTO mluvčího) } \\
& \text { a- = SOTO mluvčího i adresáta }
\end{aligned}
$$

\subsection{Další př́klady}

Pro analýzu struktury japonského jazyka z perspektivy abstraktní prostorové konceptualizace skrze UČl a SOTO se nabízí řada dalších příkladů. Na rovině lexikální Ize tímto způsobem klasifikovat např. některá substantiva, jež disponují shodným propozičním referentem, ale odlišným prostorovým konstruálem. Výrazy s obsahem <otec>, $<$ matka>, <manželka>, aj. získávají odlišnou formu pro konstruál UČl (otec = čiči, matka = haha, manželka = cuma, atd.) a pro konstruál SOTO (otec = otósan, matka = okásan, manželka = okusan, atd.). Podobně Ize nahližet na systematizaci užívání zdvořilostních osobnostních sufixů u vlastních jmen, např. Taró (UČl) vs. Taró-san (SOTO). Některá substantiva se pak v tomto ohledu překrývají se strukturací "zdvořilostních" výrazů, např. <firma> = heiša (UČl) vs. onša (SOTO). ${ }^{75}$

UČl a SOTO ovládá také užívání některých sloves. Volba slovesa s propozičním obsahem <vrátit se> je podmíněna konceptualizací cíle návratu:

(15) Gogo kaerimasu.

„Odpoledne se vrátím (domů)."

(16) Gogo modorimasu.

"Odpoledne se vrátím (*domů)."

${ }^{74}$ Dá se předpokládat, že kognitivní projekce empatie se fyzicky realizuje mj. s účastí tzv. zrcadlových neuronů (mirror neurons). Řešení skrze kognitivní projekci se dále nabízí pro případy tázacích vět s některými slovesy, jež jsou analyzována níže. K tématu empatie z perspektivy funkční syntaxe viz např. práce, jejichž autorem je v USA působící japonský lingvista Susumu Kuno.

75 Motivovanost tohoto „překrývání“ je přirozená a zřejmá, s ohledem na nemodulární a „gestaltový" charakter kognitivního systému a jazykového systému v něm. 
Sloveso kaeru předpokládá konceptualizaci cíle pohybu jako UČl. Sloveso modoru predpokládá konceptualizaci cíle pohybu jako SOTO. Podobně užínání plnovýznamových sloves iku <jít, jet> a kuru <prijijít, príijet> není vázáno na gramatickou osobu konatele, nýbrž na konceptualizaci směru pohybu: pohyb směrem (s cílem v) UČl = kuru, pohyb směrem (s cílem v) SOTO = iku.

Užití některých výrazů, např. sloves smyslového vnímání či deziderativů v př́isudkové funkci předpokládá konceptualizaci vnímajícího či toužícíno subjektu jako součást UČlm mluvčího.

(17) Fudžisan ga mieru.

"Vidím(e) horu Fudži." (*Vidí/*Vidíte horu Fudži.)

(18) Oto ga kikoeru.

"Slyším(e) (nějaké) zvuky." ( ${ }^{*}$ Slyši/*Slyšíte zvuky.)

(19) Kore ga kaitai.

"Chci/chceme si koupit toto."

(20) Are ga hošii!

„To chci!!" (*To chtějj!!**o chceš!/*To (on/ona) chce!)

Výše představený výčet je ilustrativní a v žádném prípadě není vyčerpávající. Některé další příklady projekce dichotomie UČl - SOTO např. v inventáři gramatických partikulí, formálních substantiv, gramatické kategorie času či mimetického lexika japonštiny předkládá Makino 1996.

\section{Shrnutí}

Príklady strukturace jazykového systému moderní japonštiny pomocí konceptuální dichotomie UČl - SOTO, které jsem představil v předchozí kapitole, ilustrují účelnost tohoto typu analýzy. Klasická tr̂́složková kategorie gramatické osoby, jak ji známe z evropských jazyků, kde 1. osoba primárně odkazuje k mluvčímu, 2. osoba k adresátovi a 3. k entitě mimo komunikační situaci, nenachází v popisu japonského jazyka zásadní opodstatnění. I presto se o její aplikaci na popis japonštiny někteří autoři pokoušejí (např. Nitta 1997 na rovině 
zkoumání modality). Využití perspektivy prostorové konceptualizace a prípadné zavedení kategorie oSOBA s prvky UČl a SOTO však s sebou přináší několik výhod. Jednak nabízí ucelený aparát, který je ukotven v obecných kognitivních dispozicích (jeho motivovanost Ize vysvětlit např. pomocí Teorie představových schémat, jak jsem nastínil v části 3.1), a tudíz má potenciál být intuitivně uchopitelný mluvčími různých jazyků, současně pak nabízí deskriptivní aparát, jímž lze popsat široké spektrům jevů např́č rovinami jazykového systému (lexikum, fonologie, syntax, pragmatika, ortografie aj.).

První zmíněná výhoda mưže najít uplatnění např. ve výuce japonštiny jako cizího jazyka, kde se v posledních letech začíná rozvíjet aplikace metod a výsledků výzkumů kognitivně orientované lingvistiky. Druhá výhoda je spiše teoreticko-lingvistická. Má však potenciál uchopit jevy, na nichž formalistické př́stupy selhávají. Při důslednější aplikaci zde mj. existuje určitý potenciál uznat pro japonštinu shodu podmětu s prísudkem, byṫ ne shodu morfologickou. Na prípady se slovesy dávání (viz 4.1) Ize nahlízet jako na konstrukce, v nichž musí být vztah [konatel] - [recipient] v "Iexikální" shodě se slovesem skrze kategorii OSOBA. Konfiguraci *[konatel UČl] - [recipient] - kureru/kudasaru by pak bylo možno nahlízet jako príklad porušení této shody.

Za hlavní výhodu prostorové konceptualizace UČl - SOTO v aplikaci na popis struktury japonského jazyka však Ize zajisté označit její sémiotický dosah. Díky odmítnutí modularity jazyka a mysli, a potažmo též odmítnutí modularity jazyka a kultury, se otevírá cesta k celostní analýze japonského kulturního bohatství v pojmech společných pro jazyk, společnost, náboženství, umění a další kulturní instituce. Taková analýza pak může posloužit jako model pro kulturně specifické a současně celostní poznávání dalších jazyků a s nimi spojených společenství. 


\section{Literatura}

Evans, Vyvyan 2007: A Glossary of Cognitive Linguistics [Edinburgh University Press, 239], Edinburgh.

Feldman, Jerome A. 2008: From Molecule to Metaphor. A Neural Theory of Language [The MIT Press, 384], Cambridge.

Hendry, Joy 1995: Understanding Japanese Society [Routledge, 240], New York.

Kitahara, Jasuo (ed.) 2003: Meikjó kokugo džiten. Keitaiban [Taišúkan šoten, 1813], Tókjó.

Lakoff, George - Johnson, Mark 1999: Philosophy in the Flesh: the Embodied Mind \& its Challenge to Western Thought [Basic Books, 640], New York.

Macumura, Akira (ed.) 2006: Daidžirin. Dai 3 han [Sanseidó, 2976], Tókjó.

Makino, Seiiči 1996: Uči to soto no gengo bunkagaku [ALC, 193], Tókjó.

Nitta, Jošio 1997: Nihongo bunpó kenkjú džosecu - Nihongo no kidžucu bunpó o mezašite [Kurošio šuppan, 282], Tókjó.

Sinha, Chris - Jensen de López, Kristine 2000: „Language, Culture and the Embodiment of Spatial Cognition", in: Cognitive Linguistics 11: $17-41$.

Sugimoto, Yoshio 2002: An Introduction to Japanese Society [Cambridge University Press, 316], Cambridge.

Šinmura, Izuru (ed.) 2011: Kódžien. Dai 6 han [Iwanami šoten, 3049], Tókjó.

Talmy, Leonard 2000: Toward a cognitive semantics. Volume l: Concept structuring systems [The MIT Press, 573], Cambridge.

Watanabe, Toširó - Skrzypczak, Edmund R. - Snowden, Paul (eds.) 2003: Šin waei daidžiten. Dai 5 han [Kenkjúša, 2827], Tókjó. 


\section{Mlada Mikulicová}

\section{Kniha hodin v Adamově závěti: Staroegyptský motiv v arabském středověkém textu}

\section{1 Úvod}

Pseudoepigraf z okruhu pozdně starověké a raně středověké mimobiblické literatury zvaný Adamova závět obsahuje pozoruhodné schéma periodicky opakované denní a noční dvanáctihodinové liturgie stvoření. Takové schéma není v židovsko-křestanském prostředí typické. Tradiční euchologium ukládalo večerní a ranní chvály a podle římských zvyklostí posléze i denní intervaly tercie, sexty a nony o deváté, dvanácté a třetí hodině. Tento model kopíruje křestanská praxe od rané doby. ${ }^{76}$ Spíše než denní fáze jsou doloženy týdenní periody - modlitby na každý den od pondělí do sobotní vigilie. ${ }^{77}$

Srovnání s egyptským procesem hodin v textech nekropolí se snadno nabízí. Možnost přenosu není zcela vyloučená - i jinde v židokřestanské náboženské kultuře jsou patrné egyptské vlivy, například na formulaci teologie Pentateuchu nebo na strukturu a kult jeruzalémského chrámu skrze sinajský model. V alexandrijské diaspoře vznikly helénistické verze biblické literatury (Septuaginta, Filón, Órigenés), nilské údolí vydalo podivuhodná apokryfní vyprávění, v Etiopii kolovaly specificky obohacené parabiblické spisy jako Jeskyně pokladů, Kniha Henochových tajemství, Lefâfa Ședek, a také právě Adamova závět. Křest’anské kanonické officium krystalizovalo díky mnišské mobilitě ve východním Středomoří s epicentrem ve Skétis.

76 Klement, Stromata VII 40.3. Černušková 2012, 172.

77 Divrê ha-m'ôrôt. 40 504. Segert 2007, 856-862. 
Všimněme si bliže obou textů, abychom je mohli porovnat z hlediska struktury a obsahu a rozlišit jejich ideové zacílení. Nejprve popišeme oba zdrojové texty, pak je srovnáme za účelem závěru.

\section{Horarium v Adamově závěti}

Adamova závět existuje samostatně v syrské a gruzínské verzi, zatímco etiopský a arabský text je součástí kompozitního souboru Jeskyně pokladů, kde tvoři spojnici mezi príběhem Adamovým a testamentárním cyklem genealogie předpotopních patriarchů. Syrský text ${ }^{78}$ je patrně predlohou ostatních, ač není zcela identický. Je stručnější, uvádí jiné pořadí horaria, postrádá magicko-rituální prvky a rajské reminiscence, je více biblicky orientovaný ve smyslu židovské interpretace. Arabské znění, ${ }^{79}$ vsazené do křestanské Jeskyně pokladů, zdůrazňuje teologii viny a spásy, př́značnou pro celek této parabiblické historie, která je postavena na prefigurativním paralelismu Adama a Krista - vykupitele lidského rodu. Ale i sama Adamova závět je sbírka, složená ze tř́ textů - horaria dne a noci, poutní legendy o Adamově a Kristově hrobě a liturgického improperia z velikonoční liturgie. Pochází patrně z helénistické doby, ${ }^{80}$ podobně jako například řecké znění Starého zákona, kniha Daniel, Makabejská kronika, nebo kumránské liturgické texty.

Spis je formulován jako Adamův odkaz jeho dědicovi, třetímu synu Šétovi, který jej podle výpovědi textu zapsal a předával dalšímu potomstvu. Proto má alternativní název Kniha Šétova. Sdělení horaria je vloženo do rámce testamentu, určeného $\mathrm{k}$ dalšímu předávání. Zasazením do Adamova príiběhu je dán univerzální záměr - předat návod ke komunitní liturgii.

78 Diatīqā de aban Adam, Kmoskó 1907, col. 1319-1360. V paralelních sloupcích je uveden syrský text a latinský překlad dvou recenzí, kratší a delší; horarium je obsaženo $v$ delší textu.

79 Arabský rukopis ze sinajského kláštera sv. Kateřiny. Gibson 1901, 1-56. Pařížský arabský rukopis Troupeau 1988. Etiopská verze vznikla z arabské předlohy. Edice Grébaut 1911, anglický překlad Budge 1927.

80 3. - 2. století. Stephen E. Robinson upozorňuje, že oddíly Závěti pocházejí z různých dob, s koncovou redakcí na konci třetího století AD. Robinson 1982, 990. 
Horarium sestává z tř́ částí: mudroslovného úvodu, ${ }^{81}$ popisu hodin noci a popisu hodin dne. Text popisu bohoslužby jednotlivých kategorií stvoření je stručný: jmenuje hodinu, aktéry liturgie a způsob jejího konání. V několika případech je doplněn aktualizační vsuvkou pro kněze blǐze neobjasněného rituálu, zjevně pocházejícího z jiného textu. V této úvaze se budeme věnovat pouze první části odkazu - liturgii stvoření podle horaria dne a noci.

Název pro liturgii je „konání hodin noci a dne“. Konání je v jednotlivých řádech tvorstva nazváno pozitivními termíny, nejčastěji jako služba ('ibāda), nebo zpřesněním jako bohoslužba (tašmisa), chvála (tasbiha), modlitba (șalāt), vzývání (du'ā’), oslava (tamğīd), treishagion (taqaddus), prosby (țalaba), prímluvy (taḍarru'), jásot (faraḥ), nebo i negativně: klid (hudū'). Někdy je vyjádřeno místo zvukem aktem: vystupování (irtifā'), vcházení (duchūl), vycházení (churūğ), klíčení.

Počet hodin je stanoven podle duodecimálního systému. První a poslední hodina jsou liminální okamžiky soumraku a rozbřesku. ${ }^{82}$ Liturgii většiny hodin dne konají andělské kategorie. Z hmotných jsou jmenovány hvězdy, ptáci, živočichové a lidé.

Denní liturgie začíná v první hodině chvalozpěvem (tasbiha) k Bohu. Ačkoli sinajský arabský text liturgy nejmenuje, podle jedné ze syrských verzí volají své prosby nebeštané, podle jiné syrské a podle etiopské naopak Adamovi potomci. V druhé hodině přednášejí modlitby andělé, ve třetí následuje chvalozpěv ptactva. Čtvrtá a pátá dopolední hodina je čas „konání služby“ nejprve duchovních bytostí (rūḥānijūn), pak ostatních živých tvorů (ḥajawānāt). V šesté hodině horaria, to je

81 Mudroslovný úvod začíná oslovením „poslyš synu“, známým z biblických mudrosloví: „Poslyšte synové naučení otce” (šim’û vānîm mûsar 'āb, Př 4,1; podobně Př 5,7; Ž 34,12; 66,16). I následující idiomatika je typická pro žánr naučení otce synovi: „Věz, co je třeba... Stvořitel mne poučil... dal mi pochopit". Jmenuje kategorie stvoření - zvirata a ptáky, počet hodin noci a dne, andělské rády, jejich schopnosti a úkoly.

82 Sinajský arabský text označuje hodiny číselným názvem: první, druhá, až dvanáctá, zatímco Mss Paris arabe 68 je uvádí ve formě atributivních výrazů, víceméně synonymních, jako Rozkoš, Radost, Ozdoba, Požehnání, Pokoj, Krása, Světlo, Život, Dobrodiní, Slovo, Víra, Pravda, Posila, Probuzení, Pevnost, Láska, Naděje, Milosrdenství, Vzkř̌šení, Klid, Dobro všeho stvoření. 
poledne, pronášejí prosby a prímluvy cherubové (karūbūn). Syrské znění Adamovy závěti jmenuje predmět andělských prímluv - lidi, kteří se dopouštějí nepravostí. V sedmé hodině se koná vcházení k Bohu a odcházení od něho s modlitbami „všeho živého". Podle etiopské verze jsou posly modliteb andělé. Osmá a devátá hodina jsou opět charakterizovány výrazem „služba“, v osmé je liturgie vodních a světelných bytostí (mā'āwijūn, nūrānijūn), v deváté slouží andělé, „kteří stojí před Bohem a trůnem jeho slávy". Desátá hodina je čas exorcismu skrze vodu, nad níz vzešel (țala'a) Duch svatý, takže se její démoni dávají na útěk. Na tomto místě je do stručného popisu hodiny, aktéra a úkonu vsunuta rubrika pro kněze pro zahánění zlého ducha pomazáním směsí oleje a vody. V jedenácté hodině zaznívá jásavý chvalozpěv spravedlivých a ve dvanácté pak prosebné volání všech lidí.

Noční liturgie má elementální charakter. Zahrnuje chtonní bytosti a neživou prírodu - démony, vodní a ohnivé tvory, meteorologické a vegetační jevy. Aktivní je i andělský svět a v závěru, před východem slunce i celý stvorený vesmír, kulminující v liturgii lidí.

První hodina noci náleží službě démonů, proto, jak praví rubrika textu, v této době nikomu nemohou škodit. Druhá hodina patři „velrybám a velkým vodním tvorům", třetí službě hlubinného ohně. Hlubina je nazvána biblickým pojmem Tahóm. Její enigmatičnost podtrhuje ještě nejasnější rubrika o mlčení: „V této hodině at nikdo nemluví”. Hodina mlčení je vrcholem apofatické fáze. Ve čtvrté hodině nastupují serafové s provoláváním Boží svatosti. Etiopské znění tento akt objasňuje na základě zmínky z lzajášovy vize $(6,3)$ o chvalozpěvu serafů: „provolávají Svatý, svatý, svatý". V arabském textu následuje Adamova vsuvka o visio beatifica: „Slyšel jsem je v této hodině, když jsem ještě pobýval v ráji, než jsem porušil přikázání. Když jsem pak porušil př́kaz, už jsem tyto hlasy neslyšel, ani jsem neslyšel jejich vîiivý pohyb. Už jsem nespatřil nic z těch svatých věcí, které jsem vídal v době před hříchem." Odkaz na slyšení andělských hlasů před hř́chem a ztrátu blaženého stavu je zásadní pro kontext celého spisu Jeskyně pokladů, jehož námětem jsou dějiny spásy. 
Poté následuje meteorologická sekce úkonů bouře. V páté hodině je to služba deště - „vody nad nebem", v šesté chvění a třesení mraků, které je v syrském znění nazváno „půlnoční děs". V sedmé hodině - první po půlnoci - se síly země zklidňují a rozbouřené vlny jsou zkolébány. Živly umlkají a usínají. Arabský text je opět doplněn stejnou exorcistní vsuvkou o pomazání, tentokrát toho, kdo trpí úzkostí a nespavostí. Druhá vsuvka zmiňuje Adamovu vzpomínku na ráj: „Kdysi jsem slýchal $v$ této hodině anděly vod, které jsou na výšině, jejich hlasy a hlučení, jako hluk lodí a obrovských koles." Formulace připomíná Ezechielovu vizi nebeského vozu $(1,4-9)$. Syrská verze v této hodině uvádí právě vidění nebeských zástupů. Osmá hodina zkratkovitě charakterizuje kličení zárodků ve skrytosti: ze zavlažené země vzchází tráva. Podle etiopské verze raší rostliny a stromy. $V$ deváté hodině andělé vstupují s modlitbami před Boha. Je to paralelní úkon jako v liturgii dne. Desátá hodina je čas otevření nebeských bran pro modlitby věřících. Arabský i etiopský text toto místo doplňují lidovou anekdotou o kokrhání kohoutů. ${ }^{83}$ Poslední dvě hodiny noci bohoslužba stvoření vrcholí jásotem a aktem pocty, podobně jako v denní liturgii. „V jedenácté hodině zaznívá radostný jásot po celé zemi ve chvíli, kdy slunce vstupuje do Božího ráje. Jeho paprsky vzcházejí na okrsku země a jeho svit ozařuje celé stvoření." V následující, dvanácté hodině lidé konají zápalnou obět vonného jasmínu. Na všech nebeských mocnostech nastává klid. Tímto aktem se noční horarium vrací na počátek nového dne a začíná jeho denní forma.

Horarium představuje den jako ustavičnou bohoslužbu jednotlivých kategorií stvoření. Andělské bytosti jsou aktéry třetiny z nich. Zpívají chválu, vyznání Boží svatosti, vznášejí přímluvy, předkládají lidské prosby, obklopují Boží trůn. Čas bohoslužby němých tvorů - ptáků a zvířat - je v dopoledních hodinách, úkony neživé prírody v noci. Zvláštní místo v horariu má desátá hodina dne, v níž Boží Duch posvěcuje vodu - očistný Boží akt zahánějící síly destrukce.

${ }^{83}$ V koptské a etiopské křesṫanské liturgii je uchována noční modlitba „při kokrhání kohouta". Martimort 1965, 833-834. 


\section{Horaria staroegyptských nekropolí}

Duodecimální kultovní rozvržení se nachází v egyptských horariích pohřebních textů. Časové rozpětí dokladů sahá od poloviny třetího tisíciletí a kulminuje v období Nové říše, kdy byl pưvodní systém osmnácti dekanových period rozvržen do dvanácti nočních period, duplikovaných za dne. ${ }^{84}$ Toto rozvržení času na noční obloze je zaznamenáno v královských hrobkách jako Kniha o obloze (Nut), Kniha o podsvětí (Amduat), Kniha noci a Kniha dne. Zmíněné texty však ukazují na složitější koncepci časového průběhu jako mytologicky nahlǐženého pohybu slunce $v$ prostoru. Největší zájem je v literatuře nekropolí věnován času neviditelného slunce, putujícího „skrytým prostorem" západu (cimn.t). Podsvětní periody zvané "hodiny” (wnw.t) zakládají život v jeho viditelném průběhu. ${ }^{85} \mathrm{~S}$ touto základní koncepcí se podoba skrytého dění formuluje analogicky k viditelnému jako ustavičný cyklus zjevného a skrytého umírání a oživování. Podsvětí je koncipováno jako obrácený odraz viditelného světa. ${ }^{86}$ Prostor zakládá sluneční proměny, tedy čas. ${ }^{87}$ Proto jsou jednotlivé periody sluneční trasy nazvány místním pojmoslovím: komnaty $\left({ }^{c} . t\right)$, jeskyně či útroby $(H n w)$, domy (pr), síně (wśH.t). Texty o podsvětí jsou dramaticky vizuální s útř̌ky popisu, vyprávění, nebo dialogu.

\section{Noční drama slunce}

Kniha mrtvých ${ }^{88} \mathrm{z}$ pohřebních komor králů a dvořanů ve fragmentárních výrocích identifikuje osud zemřelého $\mathrm{v}$ paralele $\mathrm{k}$ podsvětní cestě slunečního Rea analogickou krajinou vod, hor a pouště. Prochází sedmero branami, nazývá jmény jejich stráčce (formule 144-147). V hloubi podsvětní ríše se koná Usirův soud (formule 125), po kterém se zemřelý smí stát součástí Reova doprovodu a s ním vzejít nad světem lidí (formule 181-189).

\footnotetext{
84 Assmann 1995, 35ff.

85 Westendorf 1983, 71.

86 Brunner 1954, 141-145; Derchain 1975-76, 153-161; Assmann 2001, 242; Hornung v nepublikovaném článku, který cituje Hegenbarth-Reichardt 2006, 22.

87 Westendorf 1983, 71.

88 Budge 1898; Faulkner 1972; Hornung 1999.
} 
Ustálenou verzí těchto starých záznamů je Kniha o podsvětí (Amduat) z královských hrobek Nové říše ${ }^{89}$ Seriál pojednává o dvanácti hodinách noci, v nichž sluneční Re proplouvá jednotlivými branami podsvětí. Horarium noci má dvanáct oddílů, jejichž nadpis informuje o fázi cesty, její délce, charakterizuje místo, uvádí jméno hodiny a jméno jejího průvodce. Pásmo je strukturováno ve třech rovinách: prostřední vypráví hlavní děj se sluneční bárkou a její posádkou, po obou březích stojí postavy, které čekají na Reův zásah. K postavám se váže text uvádějící jejich jména, př́padně citace jejich slov - chvalozpěvu, pozdravů, Reových ustanovení a výroků. Vlastní textová část sestává z popisných a narativních útržků vyprávění s diskurzivními vsuvkami, zatímco obrázky předvádějí kontinuální sled událostí.

V první hodině noci Re se svým doprovodem vplouvá západní branou horizontu do podsvětí, oslovuje obyvatele prvního kraje jako jejich tvưrce, žádá vstup a doprovod, potvrzuje jejich právo: „Setrvávejte na svých místech“. Bytosti („bohové“) rozmanitých podob, lidských, zvîrecích i kompozitních se klanějí a zpívají chvalozpěv díků za světlo a řád v kraji sil temnoty: „Tvé slovo je spravedlnost (maat) vưči tvým protivníkům, odplata odsouzeným". Když Re opouští jejich kraj, naříkají. Vzorec oživení, povolání, jásotu za příchodu a nářku při Reově odchodu se opakuje ve všech hodinách. V druhé hodině bárku doprovázejí čty̌ri další, nesoucí znamení skrytého slunce: měsíc v úplňku, skaraba, Usirovu hlavu, rostliny budoucí vegetace. Kompozitní bytosti služebníků drží zbraně, žezla a rostlinné symboly a zpívají hymnus na Reovy proměny: „Setkáváš se s Usirem, spočíváš v kraji západu, vzcházíš jako Chepre na východě".

Ve třetí hodině Re projiždí Usirovým krajem v doprovodu Usira jako sokolího vládce a jako mumie. Zástup na břehu nese rozmanitá znamení smrti a života, boje a sjednocení vlády: pahorek, sluneční oko, nože, žezla a koruny. Je tu znamení šakala - strážce hrobky a sokola - pána paláce, stojí tu plačky a muži v hlubokém úklonu. Ve čtvrté hodině se Re ubírá vzhưru na pahorek v hadí bárce, tažené po písku.

89 18. - 21. dynastie. Verzi z hrobky Ramsese VI. popsal Piankoff 1954 a nověji Hornung 1963. Knihu o Amduatu přeložil Budge 1905. 
Jeho posádka ochránců nese znamení života: hák, anch, sluneční oko. Bytosti na břehu mají podobu hadích strážcủ s hlavami, nohama a kř́dly. V páté hodině bárku táhne dvakrát sedm bytostí se svými vưdci. Re je oslovuje, oni zdraví: „Vítej v pokoji, zaarící Re, v Sokarově kraji." Vstupuje na pahorek hrobu, na němž uprostřed kompozitních strážců skarab předjímá zrození slunce.

V šesté hodině dosahuje hlubiny podsvětí - sarkofágu. Tvoří jej ochranný had s pěti hlavami a spočívá v něm tělo, držící na hlavě skaraba. Re potvrzuje vládu devatera božstev a králů i oběti a obřady kněží a vybízí je, aby zničili jeho neprítele chtonického hada Apopa. Zástup $v$ dolní řadě oživá Reovým výrokem a znovu prijijímá úkol provázet duše zemřelých a zajištovat je obživou a vodou. Neviditelný had nese čtyři hlavy Horových synů, jimž je potvrzen úkol požírat Reovy neprátele. Další devatero zpola viditelných hadů je k tomuto úkolu oživeno a vyzbrojeno ohněm a meči.

Od sedmé hodiny Re stojí v bárce pod prístř̌eškem hadího těla. V Usirově síni koná obřady a mocnými výroky přemáhá Apopa. Neprátelé leží spoutáni, začíná fáze obnovy řádu. Trůnící vládce Hor je pověren ř́dit dráhy dvanácti hvězd a délku hodin podsvětí. Na Usirově hrobě už vyrůstá hlava oživeného. V osmé hodině Re zástup vleče jeho bárku pouští, jiný stíná hlavy Reových odpưrců. Bytosti sedící v jeskyních odpovídají Reovi nezřetelným voláním, podobným „bzukotu včel, nářku, vytí, kvílení a vzdáleného mručení". V deváté hodině dvanáct veslařu převáží Rea krajem, on jim v sokolí, býčí a beraní podobě zajištujuje chléb a pivo. Bytosti získávají oděv a stávají se Reovými průvodci. Kobry chrlí oheň, aby ozárily Reovu cestu. Devatero bohů drži hůl a anch života. V desáté hodině doprovází Reovu bárku znamení jeho denní podoby sokola a slunečního kotouče. Skarab už zvedá horizont. Dvojí osmero drži anch a žezlo. Potopené bytosti mají vystoupit z vody, ženy osvětlují cestu hadími lampami.

Jedenáctá hodina předjímá Reovo vyjití: rozzařuje se ranní hvězda, nosiči hada denních hodin se vydávají do síně východního obzoru. Bủh se sluncem na hlavě se chápe kř́idel chodícího hada, dvanáct hvězd je připraveno, duše Reových protivníků jsou potrestány. Ve dvanácté 
hodině služebnictvo vleče Reovu bárku k otvoru horizontu. Ženské postavy tvoři vánek, denní posádka nastupuje do bárky. Had ozařuje obzor ohněm, zástup pozvedá ruce $\mathrm{k}$ chvalozpěvu na toho, který právě zaujímá místo na denní obloze a vydává se ke své svatyni. Sluneční skarab dosahuje k otvoru horizontu, ústa podsvětí se za ním uzav̌̌ou.

Sluneční drama je vymezeno čtyřmi základními akty: vstupem Rea do podsvětí v první hodině, v šesté hodině obrazem životanosného spojení Rea s mrtvým tělem Usira, v sedmé hodině přemožením Apopa - kontroverzní síly chaosu, ve dvanácté hodině zrozením slunce na obzoru. Čtyři z hodin - první, šestá, sedmá a dvanáctá - jsou klícové.

\section{Horarium dne a noci}

Kromě seriálu o podsvětí je v některých hrobkách Nové riršs $e^{90}$ zlomkovitě zobrazena jiná verze o pouti slunce podsvětím, nazývaná Kniha noci. Nachází se na stropě hrobek a je postavena na obrazu nebeské klenby Nut jako ženy, která polyká slunce, a ono putuje jejím tělem k rannímu zrození. V poamarnském období je v královských hrobkách, ${ }^{91}$ na rakvích a pohřebních papyrech doložen její druhý díl zvaný Kniha dne, na němž sluneční cesta Nutiným tělem má protiklad v analogické, viditelné, denní cestě vně, podél jejího těla. ${ }^{92}$ Jako v knize o podsvětí je noční i denní perioda sluneční pouti rozčleněna na oddíly v trojité linii, s prostředním dějstvím sluneční bárky, kterou vleče zástup vedený panovníkem. Jednotlivé motivy pouti jsou podobné jako v Amduat, avšak méně souvislé. Některé hodiny chybí, kontury se slévají. Dění je chudší, spíše stereotypní. Text akcentuje úlohu panovníka Ramsese VI. a politické symboly královské ideologie sjednocené Dvoji říše..$^{93}$

\footnotetext{
90 Sethi I. v Osiriu, Merenptah, Ramses IV., Ramses VI.

91 Ramses VI., Tanis, Userkaf II., Šošenq III.

92 Popis Piankoff 1954, 389-408.

93 Hlavním hrdinou je vládce Usir, jeho protivníkem zvĩ̃ecí Sutech, v pozadí figurují dvě enneady božstev, jsou zobrazovány dvě hlavní svatyně Bútó a Hierakonpolis, bárku vlečou cizinci. V některých hrobkách bývají bez kontextu vyobrazeny právě jen hodiny, oslavující panovníka: druhá v Dér al-Bahrí, Medínit Habu, Taharqově kiosku v Karnaku, v ramessovských hrobkách Tanidy, a také osmá a devátá. Cf. Hornung 1999, 124-125.
} 
Na stropních malbách v hrobce Ramsese VI. seriál začíná vyobrazením skaraba vylétajícího na kř́llech řádu Maat. Dvojice ženských božstev Eset a Nebthet zdraví nově zrozené slunce v podobě malého sokola uprostřed slunečního disku a jeho sestup do sluneční bárky vítá posádka sedmi. Re se objevuje v zemi obyvatel horizontu, oživuje lidi, dobytek, plazy a všechno, co stvoriil. Jeho vzejití chválí král Ramses a všichni ve čtyřech stranách země: duše obou nilských břehů, božstva nekropolí (šakali) i obyvatelé „lazuritové země”.

Krajinu charakterizují hory, rostliny, obilí. V druhé hodině se za jásotu obyvatel země rozptyluje temnota, zástupy na obou březích zdraví bárku a chrání ji. Nebeská i chtonní božstva jsou zobrazena lidskými, zvir̃ecími, či kompozitními postavami. Blǐ̃e je charakterizována šestá hodina, v níz Re vyzývá svou družinu k zničení Apopa. V sedmé hodině, zvané Radostná, prochází „sláva“ slunečního boha písečným břehem, král obstál v úkladech. Také v osmé hodině bohové jásají nad zdoláním Apopa a vítězstvím krále. V deváté hodině je nebe v plném jasu a na zemi klid. Služebníci vlečou bárku k slunečnímu městu. Jeho zdi jsou z mědi, ženci sklízejí bohatou úrodu, bohové v pavilonech se radují. Re poklidně vjiždí do desáté hodiny, kdy se nebe rozhořivá, vesla se zrychlují, bárka se blǐź k západu. Jedenáctá hodina má jméno Krásná. Služebníci připevňují lano k západnímu horizontu, čtveřice šakalů doprovází sluneční disk k ústům oblohy. Ve dvanácté hodině Re klesá na západě (umírá), provázen zástupem kober a hvězd severu.

Struktura Knihy noci je stejná - cesta bárky se odvijí v prostřední řadě, v horní stojí božský zástup, $v$ dolní se odehrává oživování služebníků a hubení neprátel. Poté, co byl spolknut oblohou, vstupuje Re první branou podsvětí do druhé hodiny. Zástup vedený králem vleče bárku, bohové nahoře ho vítají, zatímco dole na vodní hladině plovou „Unavení" a „Neoblečení” čekají na svůj oděv. Re je oživuje: „Zvedněte nohy, změřte břehy". V třetí až sedmé hodině se odehrává hubení protivníků, které vede Usirův vrah Sutech, zatímco vykonavatelem pomsty je sokol Hor: „Provinili jste se proti mému otci Usirovi, avšak já, slepý, porážím jeho neprátele". Bránu osmé hodiny střeží klikatá kobra, sokol a lev. Trůnící Usir promlouvá k zajatcưm a obyvatelům země: „Unavení 
a utonulí, ponoření v Nilu, dostáváte úděl, vaše obětiny z lovu jsou zákonné, vezměte si své obilí, slunce je před vašima očima, vítr ve vašem nosu." Lid prohlašuje: "Jsme z naší země, z našeho nomu, nespáchali jsme zlo.” „K zemi! Ticho!” „On je náš král! Milujeme tohoto boha víc než všechny bohy." ${ }^{44}$ Devátá hodina je pokračováním královského výroku, který nyní pronáší k zástupům mluvčí. Desátá a jedenáctá hodina nemají bližší popis, kromě poklidných řad služebníků. Ve dvanácté hodině se koná obět' k poctě odcházejícího Rea. Služebníci pozvedají paže, před otevřenou skříňkou, v níž sedí skarab - malý Hor, kněz zapaluje vonné látky. Re vstává na horizontu, vstupuje do ranní bárky v hodině, která „vyzvedá Reovu zář a oživuje lidi, zvir̃ata, plazy a všechno, co stvořil."

Diptych Knihy dne a Knihy noci představuje celou čtyřiadvacetihodinovou periodu. $V$ úplném pohledu na cykly viditelného a neviditelného dění nese zásadní poselství egyptských nekropolí o životě, smrti a obnoveném životě. Zatímco sluneční božstvo, a tedy i pozemský panovník s ním spojený, prochází ustavičným denním a nočním procesem umírání a zrození, ostatní duše jsou fázovitě a funkčně oživované ke službě na cestě tohoto pravidelného cyklu.

\section{Závěr}

U právě předvedených textů obou literárních horarií je pozoruhodná interakce slučitelnosti a neslučitelnosti formálních a ideových prvků.

Obě horaria předvádějí kontinuální obřad trvale opakovaných cyklů dvanácti hodin dne a dvanácti hodin noci. Žánrově se jedná o rituální texty. V Adamově závěti jsou výhradně rubriky, zatímco knihy hrobek obsahující kromě rubrik také diskurzy v podobě vybídek a aklamativních odpovědí. Vizuální reprezentace je v egyptských textech klíčová: dění je předváděno spíše než popisováno. Adamovské horarium je součástí závěti, zatímco egyptské horarium dne a noci strukturuje kosmologicko-soteriologický mýtus o cestě slunce. První je postaveno na duální paralele úkonů v andělské a pozemské sféře, druhé předvádí trojdílný

94 Piankoff 1954, 424. 
seriál, v němž je centrální sluneční děj doprovázen horním pásmem symboliky božských řad a dolní linií usirovského či královského mýtu.

Obsah je v obou textech velmi rozdílný. Staroegyptský zachycuje mystérium slunce jako proces jeho transformací a současně jeho oživující funkci. Narativní motivy jsou plavba, setkávání, boj s protivníky, soud, obřadní předkládání předmětů (obětování). Rituální text je výrazně dějový. V horariu Adamovy závěti je zásadním tématem oslava Stvořitele, popsaná jako návazná liturgie jednotlivých kategorií stvoření, popis působí staticky. Linie výpovědi je biblická, s obsahovými i slovními paralelami v žalmech nebo zejména v pozdní Písni tří mládenců (Dan 3,57-90). Vypovídá o opakované kosmické bohoslužbě chval, v níz se stř́dají andělé, prírodní živly a lidé. Propojení andělské a lidské liturgie je v židovsko-ǩrestanské starověké tradici pevně zakotveno, jak dosvědčují kumránské texty (Písně sobotní oběti 40 400-407), Etiopský Henoch (Kniha podobenství 39, 1-7), pozdně helénistická Píseň tř́ mládenců (Dan 3,57-90), nebo její obdoba v Perek Šírá. Na rozdíl od těchto textů však z Adamovy závěti nevyplývá, jakými projevy se Boží chvála koná. Z liturgické tradice jsou známé především soubory žalmů a tematických hymnů (Kristova tajemství vtělení, smrti a vzkřřšení, treishagion jako trinitární chvála, breviarium - officium osmi). Tato zajímavá porovnání ale nejsou námětem této úvahy.

Odlišný je v obou sledovaných textech pojem božského. Egyptské texty podsvětí vypovídají o nehmotných skutečnostech hmotnými prostředky, vykreslují paralelu mezi tímto a oním světem. $V$ obou se projevuje božské, vyjádřeno nečekanými kompozicemi lidských, zvir̃ecích a předmětových prvkủ a proměnlivostí těchto kompozic. Pohyblivé strípky hmotných obrazů dávají nahlédnout pojmy duše, trvalosti, pokračování života. Božství není člověku přesažné, je zakódováno v něm samém, třebaže uniká. Sluneční aspekt božství, Re, je kvalifikován jako „stvoriitel”, ačkoli jeho funkce je spíše oživovací. I on sám umírá a transformuje se v nového sebe. Jeho proměny se dějí v součinnosti s jinými, spíše magicky než mysticky. Adamova závět vypovídá o Bohu jako soběstačném, nikdy neviděném Stvořiteli, o němž dosvědčuje jeho tvorstvo. Jeho surchovanost je důvodem liturgie. Chvála stvoření je 
dána řádem, stejně jako jejich kategorie. Sestoupení Božího ducha nad vodu k jejímu očištění v desáté hodině dne je príměrem stvořitelského aktu, stanovení řádu. Exorcismus Ize uplatnit až po primárním Božím aktu, aplikovat posvěcené. Člověk není partnerem, ale př́ijemcem.

Smysl obou textů je také rozchodný, třebaže oba usiluji o uchopení pojmu věčného života. Knihy noci a dne utvrzují o věčném životě člověka (panovníka) v paralelní podsvětní řrši. Vstupování individuální duše do jejího podsvětního těla je nutné periodicky obnovovat skrz sluneční cestu umírání a oživování. Dění i výrazy jsou symbolické, svědčí o jiném než aktuálně vypovídaném - tak vyjadřuji pojem duše a věčnosti. Terminologie královského mýtu dává pochopit, že věčný život je možný ve spojení s panovníkem, který se stává bohem. Adamova závět chce ujistit o funkci modlitby a o spojení liturga s andělským světem v Boží chvále. Toto pravidelné liturgické spojení jednak vyjadřuje jednotu vesmíru vưči Bohu, jednak ukazuje na věčný život v biblickém kontextu prvotního visio beatifica. Terminologie Adamova dědictví dává pochopit, že Adam-člověk má svou vlastní hodnotu a funkci, která spočívá v tom „být s Bohem”. Kontext Adamovy závěti ukazuje, že Adamovo prvotní communicatio s anděly v Boží blízkosti sice selhalo při svodu „být Bohem", ale závěrečná vize prozrazuje příchod „nového Adama“, $\checkmark$ němž se stane skutečností právě toto communio.

Typizující prvek dvakrát dvanáctihodinového schématu z egyptských textů nekropolí se v křestanské Adamově závěti uplatňuje ve shodě s teologií přesažného majestátu jediného Boha, jehož neviditelná prítomnost je obklopena a dosvědčována všemi kategoriemi stvoření. Časová perioda liturgie podtrhuje ustavičnost, tedy věčnost, a tedy smysl bytí stvořeného světa. Je to nebiblický prvek, možná prejatý právě ze zmíněného starověkého zdroje, avšak stává se modelem a schématem helénistického režimu, patrného napríklad v Písni tří mládenců nebo v kumránských liturgiích, a zcela zjevně pak v mnišské tradici denního a nočního officia, redukován na úlohu lidské komunity. 


\section{Literatura}

Assmann, Jan 1995: Stein und Zeit: Mensch und Gesellschaft im alten Ägypten, München.

Assmann, Jan 2001: Tod und Jenseits im alten Ägypten, München.

Brunner, Hellmut 1954: „Die Grenzen von Zeit und Raum bei den Ägyptern" in: Archiv für Orientforschung 17, 141-145.

Budge, Ernest Alfred Wallis 1898: The Book of the Dead, London.

Budge, Ernest Alfred Wallis 1905: The Book of Am-Tuat, London.

Budge, Ernest Alfred Wallis 1927: The Book of the Cave of Treasures, London.

Derchain, Philippe 1975-76: „Perpetuum mobile” in: Orientalia Lovaniensia Periodica 6-7, 153-161.

Faulkner, Raymond 1972: The Ancient Egyptian Book of the Dead, London.

Gibson, Margaret Dunlop 1901: Apocrypha Arabica. [Studia Sinaitica 8], London, 1-56 (Kitāb al-mağāll).

Grébaut, Sylvain 1911: „Oalementos" in: Revue de I'Orient Chrétien 16, 167-175.

Hegenbarth-Reichardt, Ina 2006: Der Raum der Zeit: eine Untersuchung zu den altägyptischen Vorstellungen und Konzeptionen von Zeit und Raum anhand des Unterweltsbuches Amduat, Wiesbaden.

Hornung, Erik 1963: Das Amduat, Wiesbaden.

Hornung, Erik 1999: The Ancient Egyptian Books of the Afterlife, Ithaca. Černušková, Veronika - Plátová, Jana (ed., překl.) 2012: Klement Alexandrijský, Stromata VII, Praha.

Kmoskó, Mihály 1907: Testamentum patris nostri Adam [Patrologia Syriaca 2], Paris, col. 1319-1360.

Salmon, Pierre 1965: "La liturgie des heures" in: Martimort, Aimé-Georges (ed.): L'Église en prière. Introduction à la liturgie, Paris - Tournai - Rome - New York, 809-902. 
Piankoff, Alexandre 1954: The Tomb of Ramesses VI [Bollingen Series 40/2], New York, 389-408 (Kniha dne), 409-428 (Kniha noci).

Robinson, Stephen Edward 1982: „The Testament of Adam” in: James Charlesworth (ed.), The Old Testament Pseudepigrapha. Chico CA, 990.

Segert, Stanislav - Dušek, Jan a kol. 2007: Rukopisy od Mrtvého moře, Praha.

Troupeau, Gérard 1988: Une version arabe du Testament d’Adam. MSS Paris arabe 68, Genève.

Westendorf, Wolfhart 1983: „Die Geburt der Zeit aus dem Raum“ in: Göttinger Miszellen 63, 71-76. 


\section{David Rafael Moulis}

\section{Judské náboženství 8. století př. Kr. ve světle archeologie}

Tento příspěvek se zabývá judskými lokalitami, na kterých je možné doložit provozování kultu v průběhu 8. století př. Kr. Nejvýznamnější centrem byl bez pochyby Jeruzalém, kde stál Šalomounưv chrám, o němž nemá archeologie žádné zprávy. Dưvodem jsou pozdější rozsáhlé stavební aktivity na Chrámové hoře a v okolí. Jen na dvou místech (Tel Arad a Tel Moca) byly objeveny zbytky oficiálních svatyní. Další města Judského království (Beer Šeba, Lakíš) svatyně neskrývaly, přesto je pravděpodobné, že se v nich nacházely. Kromě svatyní v královských městech, existovala i další kultická místa jako jsou kultické rohy, soukromé kultické místnosti, a tzv. svatyně u bran. Žádné ze dvou zkoumaných míst nevykazuje naprosto totožnou podobu kultu, liší se architektura i vybavení. Také v otázce centralizace kultu na konci 8. století př. Kr. je prokazatelné to, že kultovní místa nebyl zrušena/zničena stejným způsobem.

\section{Architektura oficiálních judských svatyní}

Na území Judska byly dodnes objeveny dvě svatyně z doby železné. Až do 2012, kdy byl ohlášen nález chrámu na lokalitě Tel Moca (na okraji Jeruzaléma), byla známa jen svatyně v Tel Aradu. Aradská svatyně prochází už po desetiletí renovacemi, protože se některé části po odkrytí zřítily. Výsledkem je velmi názorný př́klad svatyně z královské pevnosti. Oproti tomu je svatyně v Tel Moce odkryta jen částečně, a ačkoliv je jedna ze stran poničena erozí, již je možné zrekonstruovat půdorys, ze 
kterého je patrné, že se velmi podobá starozákonnímu popisu Šalomounova chrámu a lze jej datovat do období Prvního chrámu. ${ }^{95}$ Již ve 3. tis. př. Kr. se objevuje tzv. anatolský megaron (někdy označován jako severosyrský typ) se sloupovou otevřenou halou, vestibulem a hlavní místností. Tyto chrámy (včetně Šalomounova chrámu) měly tři hlavní části předsiñ, chrámovou lod' a velesvatyni. Známé jsou především z míst Tel Tayinat (10. či 9. století př. Kr.) v dnešním Turecku a z Ejn Dará (13.-10. století př. Kr.) v Sýrii. ${ }^{96}$

Severosyrská svatyně se třemi hlavními prostory byla zbudována také v judské Tel Moce. ${ }^{97}$ I tady je nutné hledat původ architektury daleko za hranicemi Judského království. $V$ Tel Aradu je vše poněkud jinak. Tamější svatyně se skládá z nádvoří, chrámové lodi a výklenku (velesvatyně). Tento výklenek není samostatnou místností, je to malá nika v zadní stěně chrámové lodi. Zásadní architektonický rozdíl mezi chrámy v Jeruzalémě (i Tel Moce) a Tel Aradem je takový, že megaron měl chrámovou lod' orientovanou na délku a v Aradu to bylo na šî́ku (vchod byl v její delší straně). Tento typ domu zde stavěli Kanaánci již v mladší době bronzové a jeho hliněný model byl objeven v kanaánském spodním městě pod judským pahorkem. Do domu i do chrámové lodi se vstupovalo delši stěnou. Před svatyní bylo zdmi ohraničené nádvoří s postranními komorami, čímž bylo docíleno půdorysu, který je znám jako typický izraelský dům o čtyřech místnostech. ${ }^{98}$ Aradský chrámový okrsek je prototypem architektury, ve které splynula lokální aradská a typická judská (izraelská) architektura.

0 existenci dalších oficiálních svatyní se vedou dlouholeté diskuze. Mezi diskutovaná města patř́ Beer Šeba a Lakišs. Lakišs byl po Jeruzalémě druhé vojensky nejvýznamněǰš judské město, které jako hlavní centrum Judska v oblasti Šefely podléhalo prímé královské kontrole. Proto i zdejší kultické místo muselo být v souladu s oficiálním

\footnotetext{
95 E-mailová korespondence se S. Kisilevitzovou.

96 Bible History Daily, Searching for the Temple of King Solomon, (online).

97 E-mailová korespondence se S. Kisilevitzovou.

${ }^{98}$ Více k typologii a podrobnostem 0 „izraelském domu“ viz Faust - Bunimovitz 2003, 22-31.
} 
Hospodinovým kultem. ${ }^{99}$ Indicií, že zde takové místo existovalo, je Lakíšský reliéf, na kterém jsou znázorněni asyrští vojáci, kteří vynášejí kadidelnice.

Obdobná situace nastala v Beer Šebě, kde žádná svatyně z doby železné nebyla odkryta, přesto je podle Z. Herzoga možné identifikovat místo, kde stávala. Teoreticky zde mohla stát svatyně již v dobách krále Davida, za jehož vlády bylo vybudováno opevněné město. Konec svatyně je spojován s vládou krále Chizkijáše, jenž nechal postavit město vrstvy II. Jedna z nových budov této vrstvy byla pojmenována podle svého umístění jako „zahloubená budova“, která kopírovala místo judské svatyně z předchozí vrstvy III. Budova byla zapuštěna do hloubky 4 metrů a při její stavbě byla poničena všechna předchozí strata. Tím došlo k rozebrání svatyně i velkého obětního oltáře. Orientace zahloubené budovy byla východ-západ a navíc byla situována v centru města. U budovy se nachází velké omítnuté nádvoří z vrstvy III, které vybízí k predstavě, že na něm stával zmíněný oltár. Pozdější hasmonejská svatyně využila pưvodní polohy potenciální judské svatyně, respektovala orientaci východ-západ. Zejména se zachovalo původní posvátné místo, které se nezapomíná a jeho charakter se zachovává po generace..$^{100}$

\section{Neoficiální kultovní místa}

V Lakiši byla odkryta kultická místnost s číslem 49, která se nacházela v sousedství pozdější helénské svatyně. Malá jednoduchá místnost s lavicemi na obětiny byla pưvodně datována do 10 . století pr. Kr. Identifikace místa byla vzhledem k nálezu malého "rohatého" kadidlového oltáře, hliněného stojanu, úlitbových misek a jiných nádob velmi snadná. ${ }^{101}$ Celkový počet kompletních kultických nádob dosáhl čísla 46. Důležitým faktem je to, že zde nebyly objeveny žádné sošky či cokoliv, co by reprezentovalo uctívané božstvo. Podle Y. Aharoniho leželo na podlaze in situ pod sutinami a popelem ze zř́ceného stropu.

\footnotetext{
99 Na'a man 1999, 405.

100 Herzog 1981, 120-122.

101 Dever 1990, 138.
} 
Do místnosti se vešel omezený počet věríích - dvě až tři osoby. V blízkosti byla nalezena kultická stéla, která mohla být společně s místností součástí většího posvátného areálu. ${ }^{102}$ Kritici, jako je D. Ussishkin a I. Finkelstein, se domnívají, že jde o stavební navážku z kdysi zničené judské svatyně a proto je představa o kultické místnosti mylná. Předměty z 9 . či 8 . století pr. Kr. byly uloženy do jámy, která byla zastavěna během budování velkého nádvoří na konci 8. století př. Kr. ${ }^{103}$

V Beer Šebě archeologové objevili rozmanitý soubor artefaktů s egyptským vlivem. 0 původu předmětů Ize jen spekulovat, protože není jasné, zda patřily cizím obchodníkům z Egypta, nebo zda byly majetkem judského obyvatelstva. Nedaleko vstupní brány byl objeven dobře zachovaný kadidlový oltář a ještě více nálezů vydaly trosky jednoho z izraelských domů z doby železné. Mezi korálky, amulety, pštrosím vejcem, glazovanou miskou, keramickou sošku ptáka, hlavou z barevného skla, spodní částí miniaturní sfingy, kostěnou hubicí ke kadidlovému oltáři, patřily i bronzové predměty (ucho od nádoby se zvir̃ecí hlavou, býček, dvojitá egyptská koruna, a egyptská bohyně). Válečkové pečetítko v asyrském či babylónském stylu bylo vyrobeno ve zdejším regionu a nese motiv božstva, pred nímž stojí prosící člověk. Podle klínopisného textu se jedná o dar, který věnoval některý z králů Transjordánska nebo Sýrie. ${ }^{104} \mathrm{~V}$ jámě, která byla vykopána v ulici před izraelským domem, byla nalezena kolekce dalších drobných artefaktů. Opět se jednalo o korálky a amulety, malého sokola (boha Hora), zdobenou úlitbovou misku a z nedaleké místnosti pocházela malá bronzová sfinga. V obytných domech byly odkryty keramické zoomorfní nádoby a zvî̃ecí figuríny, které byly spojeny s náboženskými rituály. ${ }^{105}$ Artefakty z Beer Šeby jsou do počtu i do stylu ojedinělým nálezem. V kanaánském období by takový nález nebyl nikterak výjimečným, nebot tuto oblast Egypt ovládal, ale i v pozdějším období probíhaly obchodní či kulturní kontakty Beer Šeby s Egyptem.

\footnotetext{
102 Zevit 2003, 214-218.

103 Finkelstein - Silberman 2006, 272-273.

104 Aharoni 1972, 119-125.

105 Aharoni 1972, 126.
} 
Poblǐz Beer Šeby leži lokalita Tel Chalíf, na níž byla objevena kultická místnost, jež byla součástí izraelského domu. Nejdřive se jednalo o běžný domácí prostor, který byl až později proměněn v kultickou místnost s lavicemi po obvodu. ${ }^{106}$ Místnost zde v biblickém Rimónu byla vybudována a užívána ženami od 9 . století př. Kr. až do roku 701 př. Kr., kdy bylo město zničeno a vypáleno Sinacheribem. ${ }^{107}$ Ke kultickým artefaktưm, které byly vykopány, patři terakotová hlava Ašery, keramický podstavec od kadidlového oltáře, dva vápencové bloky (stély) a kámen sloužící jako symbolický obětní stůl. Toto kultovní místo sloužilo jako privátní svatyně majitele domu. ${ }^{108}$ Jak je možné, že místo existovalo až do roku 701 př. Kr. a přečkalo Chizkijášovy reformy? Odpověd’ můžeme nalézt v soukromém charakteru kultické místnosti, v níz se nemusely konat zápalné oběti. Obětiny se předkládaly na obětní stůl a završením rituálu bylo pálení kadidla. Na takové prostory se Chizkijášova kultická reforma nevztahovala, protože byla zaměřena na královské oficiální svatyne. ${ }^{109}$

\section{Obětní a kadidlové oltáře}

Velké obětní oltáře, které stávaly na nádvořích před chrámy, byly jejich nezbytnou součástí k pálení obětin. Aradský obětní oltár byl postaven podle starozákonních pokynů (Ex 20,24-26) z neopracovaných polních kamenů spojených hlínou. Jeho výška po odkrytí byla 1,5 metru nad podlahou. Tento rozměr ovšem zahrnuje dvě stavební fáze a oltář vždy měřil přibližně tři čtvrtě metru (ve druhé stavební fázi byla zvýšen okolní terén a proto byl dostavěn i oltář). Nebyly u něho nalezeny známé rohy, o kterých se piše v Bibli (Ex 27,1-2) a které známe z oltářu z Beer Šeby, Megida, Gatu a Ekronu. Protože byl oltář zakryt zeminou $\checkmark$ podobě, v jaké přestal být používán, byla nalezena i svrchní deska z křemene a sádrové kanálky na odvedení krve. Na desce jsou patrné stopy po používání kovového roštu, na který se umistovalo maso. Je

\footnotetext{
106 Borowski 1995, 151.

107 Borowski Tell Halif, May 2010 (online).

108 Borowski 1995, 151-152.

109 Borowski 1995, 152 a Lowery 1991, 158.
} 


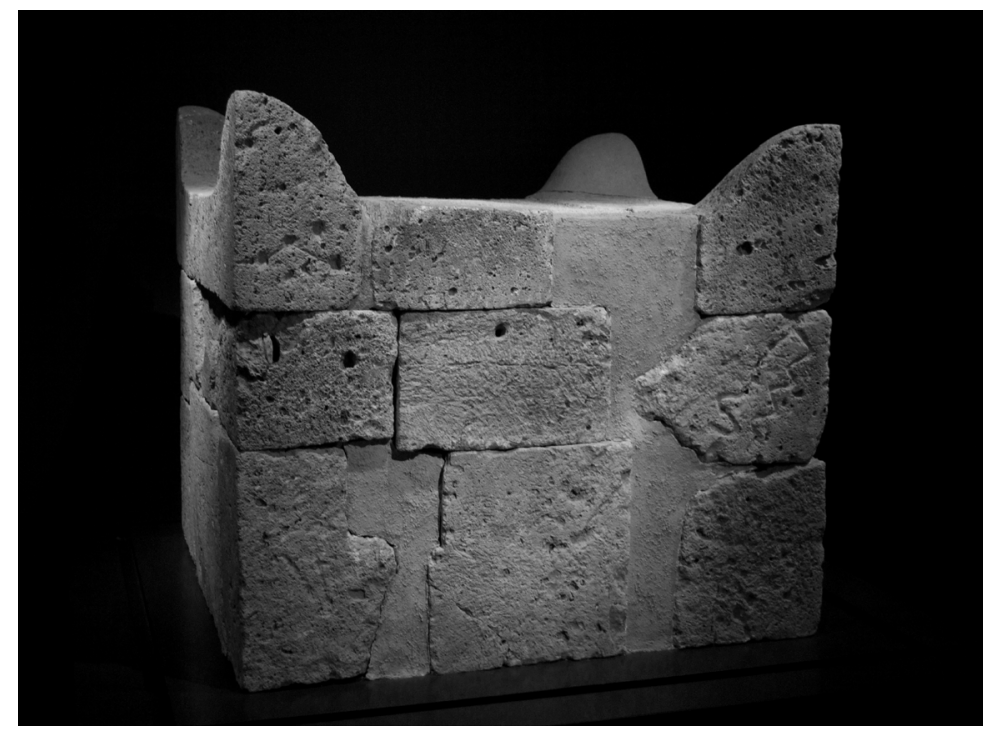

Obrázek 1. Rohatý oltáŕ z Beer Šeby (rekonstrukce z původních kamenů, Izraelské muzeum, Jeruzalém), foto: autor.

proto možné, že až tento rošt, mohl mít ony rohy. Jejich praktický účel už dnes není znám, ale sloužily ke znehybnění neposlušného obětovaného zvir̃ete, nebo na nich stál kovový rošt. ${ }^{110}$ Ten byl nutným komponentem pro pálení obětí a odkazuje na něho i Méšova stéla, nalezená v Moábu. ${ }^{111}$

Na nádvoří svatyně v Tel Moce byl odkryt oltáŕ o príbližné výšce 1,4 metru a ani on nemá rohy. Byl zhotoven ze tř́ vrstev neopracovaných polních kamenů jako oltár v Tel Aradu. Severovýchodně od něho se nacházela odpadní jáma, která byla vyplněna rozbitými kultickými předměty, keramikou, popelem a celou řadou kostí mladých kulticky čistých zvir̃at.

Učebnicový př́klad rohatého oltáře pochází z Beer Šeby z vrstvy III (obrázek č. 1). Později byl rozebrán a některé z kamenů byly použity

110 Fowler 1984, 183.

111 Coogan - Exum - Stager 1994, 338. 
při výstavbě veřejných stájí a skladiště za vlády Chizkijáše. ${ }^{112}$ Některé kameny s rohy byly zabudovány do základů stavby, u jednoho z nich musel být roh odstraněn, což je důkazem toho, že obyvatelé Beer Šeby tyto stavební prvky již více nepovažovali za posvátné. Další kameny původem z obětního oltáře byly skryty v rampě nedaleko městské brány. Objevené kameny tvoří zhruba jen polovinu původního oltáre. Konec vrstvy II je spojen se Sinacheribovým tažením v roce 701 pr. Kr. ${ }^{113} \mathrm{Na}$ jednom z dochovaných kamenů oltáre je vyrytá klikatá čára, která je spojována se starověkým symbolem plodnosti - hadem, který byl podle Knih královských ${ }^{114}$ uctíván i v Jeruzalémě a znám jako Nechuštán. ${ }^{115}$

Kromě velkých obětních oltářu se využívaly i menší kadidlové oltáře. Dva takové byly nalezeny na schodech před aradskou velesvatyní, v místech, kde byly pưvodně užívány. Na jejich horní ploše je prohlubeň, v níz byly zachovány zbytky spáleného organického materiálu. Dodnes nebyla provedena analýza a badatelé se přou, zda jde o zbytky živočišného tuku, nebo kadidla. ${ }^{116} Z$ toho, co víme 0 těchto oltárích, je více než pravděpodobné, že sloužily k pálení kadidla a jejich jediným účelem bylo vytvořit vonný oblak pro kněze, který vykonával obřady v chrámové lodi. Kadidlo před Hospodinem zapaloval kněz každé ráno a večer, aby pro Hospodina navodil př́jemnou atmosféru. ${ }^{17} \mathrm{~V}$ Judsku, Izraeli a v asyrském Ninive se nalezlo více než čtyríicet pět vápencových kadidlových oltáŕu a přes třicet z nich mělo rohy. ${ }^{118}$ Kadidlo bylo páleno rovněž v keramických miskách na dutém podstavci. Tyto kadidelnice bývají zdobeny okvětními lístky lotosu. Ne vždy Ize jednoznačně ríci, zda skutečně takovýto predmět sloužil jako kultický. ${ }^{119}$ Kadidelnice byly někdy nalézány v asyrských trůnních sálech z 8. století př. Kr., kde sloužily jako topení a proto M. D. Fowler navrhuje v některých prípadech

\footnotetext{
112 Halpern 2009, 355.

113 Herzog 2010, 176-177.

$1142 \mathrm{Kr} 18,4$.

115 Aharoni 1974, 4-5.

116 Aharoni 1967, 247 a Dever 2012, 259.

117 Cushman 1999, 115.

118 Gittlen 2002, 109.

119 Grutz 2005, 5-6.
} 
aplikovat tuto teorii i na nálezy v dnešním Izraeli. ${ }^{120}$ Jedna kadidelnice byla objevena u svatyně v Aradu a totožný okvětními lístky dekorovaný model se našel i v Tel Moce. ${ }^{121}$ Další dvě jsou vyobrazeny na již zmíněném lakíšském reliéfu v královském paláci v Ninive. ${ }^{122}$

\section{Kultické stély}

Jelikož je oficiální judský kult považován za anikonický, jediným prípustným objektem, který připomínal Hospodinovo jméno, mohla být kultická stéla. V Judsku a Izraeli je se stélami potiž v tom, že neobsahují žádné texty, ani antropomorfní či zoomorfní výjevy, a proto jsou zdejší stély němé. 0 jejich skutečném účelu může napovědět jen kontext nálezu. Ze starověkého Předního východu je známo, že stéla mohla sloužit jako hraniční kámen, zákoník, smlouva, či místo, kde se projevilo božstvo. Kromě jedné stély z Lakíše, pocházejí dvě z Tel Aradu. Opracovaná a zaoblená 90 centimetrů vysoká maceva se zbytky červené barvy byla položena na boku v centrální části aradské velesvatyně. Tam stávala přinejmenším ve vrstvě IX a pravděpodobně i ve vrstvě X. Její poloha a opracování jsou důkazem toho, že jde o kultickou stélu, k niž se symbolicky ubíral zájem veřících. 0 původu kamene toho nelze přiliš zjistit a C. F. Graesser nabízí možnost, že mohlo jít o starou stélu, vztyčenou jako památník Hospodinovi za to, že pomohl k vítězství zdejší vojenské posádky. ${ }^{123}$ Druhá aradská stéla je zahalena tajemstvím, nebot' byla odkryta zazděná pod omítkou $v$ zadní stěně velesvatyně a věrící o ní neměli ponětí. Bud’ byla starou stélou, která už nebyla použivána, ale vzhledem k posvátnému charakteru ji bylo nutné uložit $\checkmark$ nejsvětěǰším prostoru, nebo sloužila paralelně s první stélou.

B. Halpern nejprve spojuje dvě stély a dva kadidlové oltáre s ženským (Ašerou) a mužským (Baalem) božským aspektem. Každá stéla měla svůj kadidlový oltár. Podle Halperna byla Hospodinovi určena větší stéla ve velesvatyni a velký obětní oltár na nádvoří. Menší stéla

\footnotetext{
120 Fowler 1984, 184.

121 Kisilevitz 2013, 38-40.

122 Herzog 2002, 58.

123 Graesser 1972, 52.
} 
reprezentovala Baala a Ašeru zastupoval (nedochovaný) dřevěný kůl. Ašeře a Baalovi patřily dva vápencové kadidlové oltáře, schované pod zeminou na schodech do velesvatyně. ${ }^{124}$ Tato teorie nemá př́liš zastánců a její autor se ž̌ejmě nechal inspirovat písemnými materiály z 8. století př. Kr., o kterých bude řeč dále.

\section{Zoomorfní a antropomorfní artefakty - lidová víra}

Pestrá škála předmětů, kterým bude nyní věnován prostor, se dá rozdělit do dvou základních skupin. Na převládající antropomorfní sošky (jezdce na koni, Ašery, neboli judské sloupcovité figuríny) a antropomorfní artefakty. $V$ lidové vî̃e $v$ Judsku stále pretrvávaly staré kanaánské a lidové tradice, které lidé mohli volně provozovat v domácnostech, nebo v soukromích (rodinných) kultovních místech.

Např́klad na nádvoří chrámu v Tel Moce byla na ploše o rozloze 1x1,5 metru poházená rozbitá keramika, včetně čtyř figurín (dvě antropomorfní a dvě zoomorfní), které mají typické vypouklé oči, dlouhé brady, velké nosy a vlasy, které prípomínají dredy. Obě hlavy mají stylizované vousy. Ploché kulaté pokrývky hlavy jsou typické zejména pro egejskou oblast, ale byly nalezeny i v Chirbet Qeyiafě, Bét Šeánu a na dalších místech Judska i lzraele. Na zoomorfní sošce lze jen tě̌̌ko rozpoznat, o jaké zvir̃e se jedná. Materiál všech čty̌r figurín je zdejší, i když původ (inspiraci) předmětů je nutno hledat v okolí Egejského moře. Tyto sošky se v Judsku i lzraeli začaly hojně objevovat až v době železné llb (převážně v soukromých budovách a v hrobech) a na Tel Moce předměty překvapivě pocházejí již z doby železné lla. Ze stejného období pochází i podstavec ke keramické misce s tlapami a ocasy dvou Ivů anatolského typu. ${ }^{125}$ Všechny kultické předměty (figuríny i rituální nádoby) byly záměrně rozbity a posypány popelem. Posléze byly v 8 . století př. Kr. i s oltářem zavezeny hlínou. Kisilevitzová príipouští, že by tato událost mohla být spojena s Chizkijášovou reformou. ${ }^{126}$

\footnotetext{
124 Halpern 2009, 88.

125 Kisilevitz 2013, 41-43.

126 Kisilevitz 2013, 44.
} 


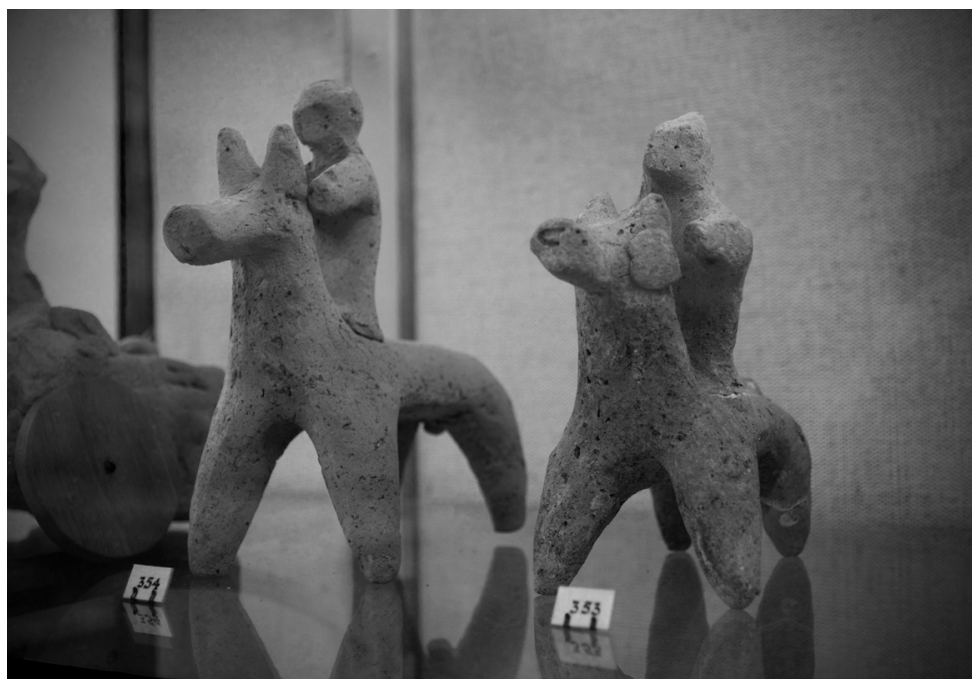

Obrázek 2. Jezdec na koni (bez bližších údajů, Rockefellerovo muzeum, Jeruzalém), foto: autor.

V Judsku je nacházen antropomorfní artefakt, jehož interpretace je velmi nejistá, přesto bývá spojován s kultem a dokonce je dáván do přímé souvislosti s Hospodinem - válečníkem. ${ }^{127}$ Jde 0 tzv. jezdce na koni (obrázek č. 2). Poslední takové nálezy pocházejí z okolí chrámu v Tel Moce. Zdali je tato interpretace správná, je jen těžko ověřitelné. Z kontextu nálezu se zdá, že by předmět mohl být skutečně používán při rituálech v rámci lidových praktik. Také v Aradu byl v malé komoře na chrámovém nádvoří nalezen zlomek této sošky. U mnoha jiných jezdců není známo místo objevu. Z Města Davidova v Jeruzalémě pochází soška koně, ale bez jezdce a i tento typ pohanské sošky bývá asociován s Hospodinem.

K soškám žen je obecně nutno zmínit, že mohou mít několik funkcí. Pokud byly nalezeny v hrobech, šlo o prostý dar mrtvému. Často jsou nalézány rozbité a ve většině prípadů je objevena pouze hlava. Pokud má být soška kultickým předmětem, byla k rituálům zapotřebí

127 Uehlinger 1997, 152. 
celá a lidé se jí symbolicky dotýkali, což dokládají ohlazené plochy na hlavě či ve spodní části těla. Tyto Ašery (též judské sloupcovité figuríny) vydala kultická místa, jeskyně a místa u vody. V prípadě, že byly sošky užívány k magickým rituálům, bývaly záměrně poškozeny či spáleny. Poslední funkcí Ašer bylo jejich využívání během rituálu zasvěcení, kdy byla soška nesena za spodní část (sloupec). Sošky jsou často nalézány mimo jakýkoliv kontext, na svazích pod lokalitami či v místech, kde se promíchalo několik vrstev, a proto je těžké hovořit o jejich přesné dataci či původní funkci. Nacházené osamocené hlavy vyvolávají dojem, že mohlo docházet k jejich sekundárnímu užívání, které mělo jiný účel. ${ }^{128}$

Z typologického hlediska Ize podle většiny sošek z Města Davidova v Jeruzalémě konstatovat, že jsou až na drobné výjimky charakteristické pro Judsko. ${ }^{129}$ Těla sošek byla modelována ručně, zatímco hlavy byly často vytlačovány do forem, které se rovněž zachovaly (obrázek č. 3). Jen v Jeruzalémě bylo dodnes nalezeno více jak 2000 Ašer, ale ne všechny jsou kompletní. V Aradu byly nalezeny fragmenty z 23 sošek (13 hlav a 10 těl), v Beer Šebě 43 a v Lakíši 29 Ašer. Aradské sošky měly původně velikost od 25 do $90 \mathrm{~cm}$ a na třech z nich jsou stopy po červené barvě. ${ }^{130}$ Ašery se obecně objevovaly od 10 . století př. Kr. až do perského období, ale největší množství nálezů pochází z 8. století př. Kr. Kult Ašery je opět projevem starých lidových praktik, které byly pro obyvatele neoddělitelnou součástí života, zejména v oblasti plodnosti. ${ }^{131}$

$\checkmark$ roce 1990 byla na trhu se starověkými předměty $v$ Jeruzalémě zakoupena terakotová soška z místa Tel Bét Mirsím (nachází se mezi Hebronem a Beer Šebou). Soška je judského původu a pochází z konce 8. nebo počátku 7. století př. Kr. Dvě postavy, muž a žena sedí na trůnu a opěradla jsou tvořena sfingami. Vousatý muž je větší, sedí v popředí ve středu trůnu a svoji šîrkou zabírá většinu prostoru. Žena stojí v pozadí za mužem. Sfingy mají v tomto výjevu stejný význam jako cherubíni

\footnotetext{
128 Kletter 1996, 82.

129 Gilbert-Peretz 1996, 29-37.

130 Kletter 1996, 95 a147.

131 E-mailová korespondence s R. Kletterem.
} 


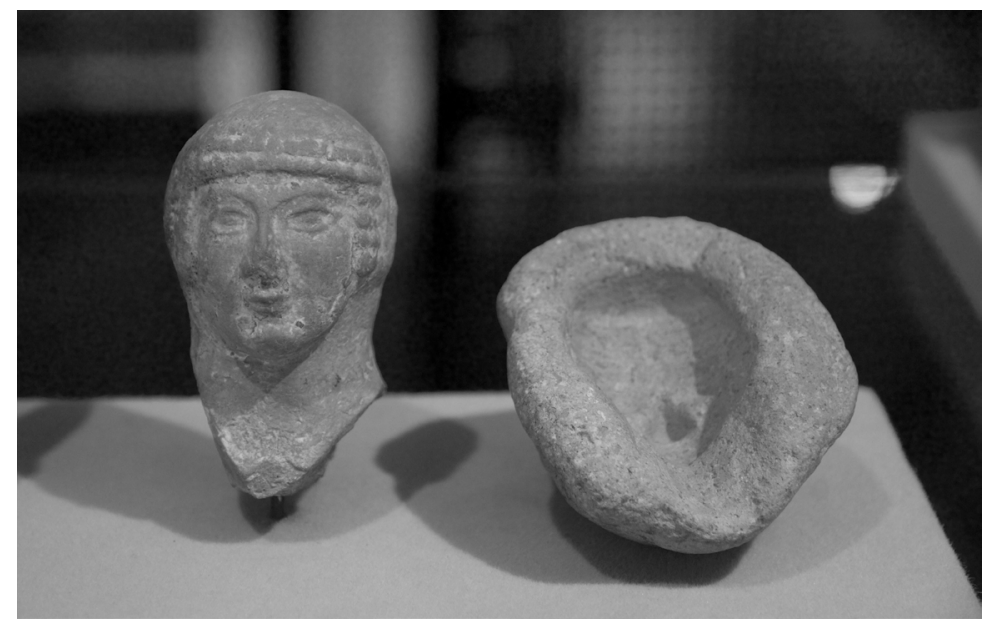

Obrázek 3. Hlava bohyně plodnosti - Ašery a forma na jejich výrobu (Judsko, 8. století př. Kr., Muzeum země Izraelské, Tel Aviv), foto: autor.

a tak Uehlinger nabízí možnost, že jde o vyobrazení Hospodina a jeho družky Ašery. Bližší kontext nálezu není archeologům znám, a proto je třeba tento výklad považovat za jeden z možných. ${ }^{132}$

\section{Epigrafické nálezy zmiňující Hospodina}

Cenné epigrafické nálezy pomáhají pochopit otázku božského páru. Pro oblast Předního východu byl takový pár naprosto běžnou součástí kultického života a ne jinak tomu bylo podle dochovaných textů v Judsku. Toto pojetí je výsledkem lokálního náboženského mikrosystému. Nedaleko Lakiše v místě Chirbet el-0om byl do hrobky ve skále vytesán text, který paleografické průzkumy datovaly do 2. poloviny 8. století př. Kr. (obrázek č. 4). Pozoruhodné na něm je, že i na tomto relativně krátkém textu je zmíněn Hospodin (Jhvh a jeho Ašera):133

132 Uehlinger 1997, 150-152.

133 Zevit 1984, 39-40. 


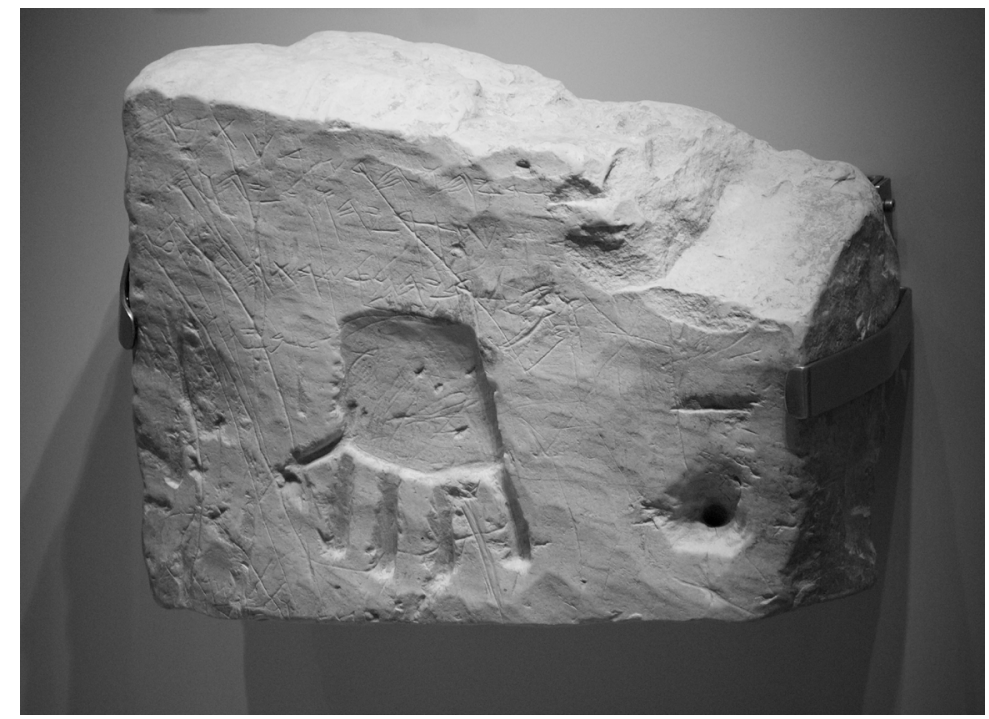

Obrázek 4. Sejmutý nápis z Chirbet el-Oom (lzraelské muzeum, Jeruzalém), foto: autor.

"1 Urí-Jáhú, velitel, toto napsal:

2 Požehnán budiž Urí-Jáhú prí Jhvh

3 a od jeho neprătel, prí jeho (=Jhvh) ašeře, jej zachrañ... "'34

Jiná lokalita Kuntillet Adžrud s jedinou sídelní vrstvou z 8. století př. Kr. se nachází na obchodní stezce, která vedla z Gazy do Élatu a byla spravována Judskem. Archeologický výzkum odkryl vedle brány budovu o dvou místnostech s omítnutými lavicemi a nápisy na stěnách, mezi nimiž se objevila jména Hospodina a Baal, která doplňovala požehnání. Tato struktura byla interpretována jako malá svatyně. ${ }^{135}$ Došlo zde k nálezu dvou keramických zásobnic (označovány A a B), na kterých jsou nápisy a kresby postav. Kresby mohou znázorňovat Hospodina a Ašeru, o nichž píše dochovaný text. Uehlinger si povšiml, že text je napsán přes postavu, jako by nebyla důležitá a proto od pưvodní teorie, že je

134 Antalík - Čech - Dušek - Mynářová 2014, 212.

135 Dever 1990, 140. 
zde vyobrazen Hospodin, upustil. Přesto nepopírá, že samotný nápis jednoznačně hovoří 0 božském páru. ${ }^{136}$

Petrografický rozbor materiálu prokázal, že je jeho původ v okolí Jeruzaléma. Na nádobě A jsou ztvárněni dva korunovaní muži (napůl člověk a napưl lev), polooděná žena hrající na lyru, tele, sající mléko matky, dva kozorožci okusující keř, lev, další tři zvir̃ata a text označovaný jako požehnání. Na nádobě $B$, je pět postav, které uctívají božstvo, kráva, kozorožec, lev a lučištník. ${ }^{137}$ Podle $W$. Devera hrající žena z nádoby $B$ sedí na trůnu, který je stylizovaným Ivím trůnem spojovaným s Ašerou, a proto zdejší kult označuje za polopohanský, kde byl kromě vedle Hospodina a Ašery uctíván ještě Baal. ${ }^{138}$

Na textu ze zásobnice A je zmíněn Hospodin s apelativem samařský a jeho Ašera:

„...2 při Jhvh samařském a při jeho ašeře."

Na zásobnici B se dozvídáme o Hospodinu témanském (doslova Hospodin jihu):

"1 ] pro Jhvh témanského a jeho ašeru...."140

Transreligiózní fenomén nebyl ničím neobvyklým. Docházelo v něm k uctívání stejného Hospodina pod různými apelativy. ${ }^{141}$ Jiný takový příklad byl objeven v judském místě zvaném Chirbet Bét Lej, kde je psáno o Hospodinu, Bohu Jeruzaléma:142

„JHVH je Bưh celého světa

Patři mu judská země, Bohu Jeruzaléma"143

136 Uehlinger 1997, 136-146.

137 Edelman 2010, 96-97.

138 Dever 1990, 144-148.

139 Antalík - Čech - Dušek - Mynářová 2014, 183.

140 Antalík - Čech - Dušek - Mynářová 2014, 184.

141 Antalík 1996, 134.

142 Niehr 2010, 31.

${ }^{143}$ Vlastní překlad autora z angličtiny. In: Becking - Dijkstra - Korpel - Vriezen 2001, 37. 


\section{Závěrem}

Centralizace judského kultu je spojena s pádem severního Izraelského království. Následovalo zničení svatyní severního království a posléze i těch judských. Nenásilné částečné demontování svatyní v Tel Aradu a Tel Moce je datováno přibližně do roku 715 př. Kr., kdy vládl Chizkijášs. Svatyně nenesou náznaky vypálení ani násilné destrukce, které by způsobila likvidace míst tak, jak je popisuje Starý zákon. Neexistují ani známky po Sinacharibově invazi, což je dokladem toho, že už v této době byly svatyně mimo provoz. ${ }^{144}$ Herzogův revizní průzkum zjistil, že aradská svatyně byla použivána pouze ve dvou sídelních vrstvách XI a X, což znamená, že se tomu tak dělo jen v malé části 8 . století př. Kr. Chrám se nepoužival pưvodně předpokládaných 350 let (od 10. století př. Kr.), nýbrž méně než 50 let. ${ }^{45}$

V Judsku jsou známa čtyri kultická místa, která byla na konci 8. století př. Kr. proměněna vlivem reformy (Tel Arad, Beer Šeba, Lakišs a Tel Moca). Kultické změny se týkaly jen oficiálních královských svatyní a zdá se, že nebylo přesně definováno, zda mají být úplně zničeny, nebo jen vyřazeny z provozu. V Beer Šebě byl oltáŕ rozebrán, ale v nedalekém Tel Aradu a v Tel Moce byly oltáře zavezeny zeminou a zakonzervovány. Samotným svatyním byly sniženy zdi a rovněž byly zasypány. Chizkijáš neměl striktní pravidla pro svoji reformu, stejně jako kdysi nebyla pevná pravidla pro to, jakou podobu má mít kult a jak mají vypadat např́iklad oltáře a i v královských městech, kde byly oficiální svatyně, není nouze o nejrůzněǰ̌i pohanské předměty, které lidé běžně používali k náboženským rituálům a nemohli se jich pod vlivem kultu Hospodina tak jednoduše vzdát. ${ }^{146}$

\footnotetext{
144 Herzog 2002, 67.

145 Herzog 2002, 49-51.

146 Herzog 2010, 169-199 a Herzog 2002, 178.
} 


\section{Literatura}

\section{Monografie}

Antalík, Dalibor - Čech, Pavel - Dušek, Jan - Mynářová, Jana 2014:

Na stezkách domu Baalova: Náboženské texty literární a kultické. Praha.

Becking, Bob - Dijkstra, Meindert - Korpel, Mario, C., A. - Vriezen, Karel, J., H. 2001: Only One God? Monotheism in Ancient Israel and the Veneration of the Goddess Asherah. London - New York.

Bible. Písmo svaté Starého a Nového zákona. Podle ekumenického vydání z r. 1985. Praha.

Coogan, Michael, D. - Exum, Cheryl, J. - Stager, Lawrence, E. 1994: Scripture and Other Artifacts: Essays on the Bible and Archaeology in Honor of Philip J. Jing. Louisville - Kentucky.

Dever, William, G. 1990: Recent Archaeological Discoveries and Biblical Research. Seattle - London.

Dever, William, G. 2012: The Lives of Ordinary People in Ancient Israel: Where Archaeology and the Bible Intersect. Cambridge.

Halpern, Baruch 2009: From Gods to God: The Dynamics of Iron Age Cosmologies. Tübingen.

Kletter, Raz 1996: The Judean Pillar-Figurines and the Archaeology of Asherah. Oxford.

Lowery, Richard, H. 1991: The Reforming Kings, Cults and Society in First Temple Judah. Sheffield.

Zevit, Ziony 2003: The Religions of Ancient Israel: A Synthesis of Parallactic Approaches. Místo neznámo.

\section{Kapitola v monografii}

Edelman, Diana 2010: Cultic Sites and Complexes Beyond the Jerusalem Temple, in: Stavrakopoulou, Francesca - Barton, John (eds.), Religious diversity in Ancient Israel and Judah. London, str. 82-104. 
Gilbert-Peretz, Diana 1996: Ceramic Figurines, in: Ariel, Donald, T. - Groot, Alon de, QEDEM: City of David Excavations: Final Report IV: 1978-1985: Directed by Yigal Shiloh. Jerusalem, 29-41.

Herzog, Ze'ev 1981: Israelite Sanctuaries at Arad and Beer-Sheba in: Biran, Avraham, Temples and High Places in Biblical Times: Proceedings of the Colloquium. Jerusalem, 120-122.

Herzog, Ze'ev 2010: Perspectives on Southern Israel's Cult Centralization: Arad and Beer-sheba, in: Kratz, R. G. - Spieckermann, H. (eds.).. One God, One Cult, One Nation : Archaeological and Biblical Perspectives. Berlin - New York, 169-199.

Niehr, Herbert 2010: 'Israelite'Religion and 'Canaanite'Religion, in: Stavrakopoulou, Francesca, Barton, John (eds.), Religious diversity in Ancient Israel and Judah. London, 23-37.

Uehlinger, Christoph 1997: Anthropomorphic Cult Statuary in Iron Age Palestine and the Search for Yahweh's Cult Images. In: Toorn, Karel van der, The Image and the Book Iconic Cults, Aniconism, and the Rise of Book Religion in Israel and the Ancient Near East. Leuven.

\section{Článek v časopise}

Aharoni, Yohanan 1967: Excavations at Tel Arad: Preliminary Report on the Second Season, 1963, in: The Israel Exploration Journal 17, 233-249.

Aharoni, Yohanan 1972: Excavations at Tel Beer-sheba, in: The Biblical Archaeoligist XXXV, 111-127.

Aharoni, Yohanan, The Horned Altar of Beer-sheba, in: The Biblical Archaeoligist 37, 2-6.

Antalík, Dalibor, 1996: Jahve a jeho paredros v náboženství předexilního Izraele, in: Religio 4, 127-138.

Borowski, Oded 1995: Hezekiah's Reforms and the Revolt Against Assyria, in: The Biblical Archaeoligist 58, 148-155.

Faust, Avraham - Bunimovitz, Shlomo 2003: The Four Room House: Embodying Iron Age Israelite Society, in: Near Eastern Archaeology 66, 22-31. 
Finkelstein, Israel - Silberman, Neil Asher 2006: Temple and Dynasty: Hezekiah, the Remaking of Judah and the Rise of the Pan-Israelite Ideology, in: The Jounal for the Study of the Old Testament30, 259-285.

Fowler, Mervyn, D. 1984: „BA“ Guide to Artifacts: Excavated Incense Burners, in: The Biblical Archaeoligist 47, 183-186.

Gittlen, Barry (ed.), M. 2002: Sacred Time, Sacred Place: Archaeology and the Religion of Israel. USA.

Graesser, Carl, F. 1972: Standing Stones in Ancient Palestine, in: The Biblical Archaeoligist 35, 33-63.

Herzog, Ze'ev 2002: The Fortress Mound at Tel Arad an Interim Report, in: Tel Aviv 29, 3-109.

Grutz, Robert 2005: Chalices in Ancient Israel: Late Bronze Age and Iron Age. místo neuvedeno.

Kisilevitz, Shua 2013: Kultické nálezy z doby železné z archeologického výzkumu v Moce (hebrejsky), in: New Studies in the Archaeology of Jerusalem and Its Region (hebrejsky) 7, 38-46.

Na'aman, Nadav 1999: No Anthropomorphic Graven Images: Notes on the Assumed Anthropomorphic Cult Statues in the Temples of YHWH in the Pre-Exilic Period, in: Ugarit-Forschungen 31, 391-415.

Zevit, Ziony 1984: The Khirbet el-Qôm Inscription Mentioning a Goddess, in: The Bulletin of the American Schools of Oriental Research 255, 39-47.

\section{Kvalifikační práce}

Cushman, Beverly, White 1999: Text and Architecture: The Deuteronomistic Theology of Space of the "Solomonic Temple". Disertační práce, Graduate School of Vanderbilt University, Nashville.

\section{Internetové články}

Bible History Daily, Searching for the Temple of King Solomon. [online]. Citováno dne 19. 1. 2014. URL: http://www.biblicalarchaeology.org/ daily/biblical-sites-places/temple-at-jerusalem/searching-for-thetemple-of-king-solomon/ 
Borowski, Oded, 2010: Tell Halif, [online]. The Bible and Interpretation, Citováno dne 3. 7. 2014. URL: http://www.bibleinterp.com/articles/ halif357921.shtml

\section{E-mailová korespondence}

E-mailová korespondence s Shuou Kisilevitz, M.A. (Izraelský úrad pro starožitnosti), 27. 10. 2013.

E-mailová korespondence s dr. Razem Kletterem (Univerzita Helsinki), 28. 2. 2014. 


\section{Marie Peterková Hlouchová}

\section{Rostliny zbožštěné ve slunečním kultu egyptské Staré říše}

Staroegyptské náboženství prostupovalo všemi oblastmi života obyvatel nilského údolí a bylo dosti ovlivněno prostředím, ve kterém tito lidé žili. Egyptané samožrejmě vnímali ostrý předěl mezi úrodným údolím a neúrodnou pouští, byli si vědomi důležitosti Nilu a jejich pozornosti neušla ani tělesa, které viděli každou noc a každý den na obloze. Tyto přírodní děje pak reflektovali v náboženské rovině, což je patrné např́klad na zobrazeních bohyně nebeské klenby Nuty, jejíz tělo se klene nad postavou boha země Geba, a mezi nimi spočivá jejich otec Šu, bůh spojovaný se světlem a horkým vzduchem. Po těle bohyně Nuty se ve svých dvou bárkách, denní a noční, plaví sluneční bůh Re (obr. 1). Jedná se tedy o kosmografické zobrazení, o převedení reálného světa do náboženského pojetí. Kromě toho do náboženských představ pronikli také různí zástupci fauny a flóry, kteří byli spojováni s mnohými aspekty egyptských božstev. V podstatě již od nejstarších dob je doloženo uctívání posvátných zvir̃at, která byla chápána jako ba nějakého boha, tedy jako jeho pozemské vtělení nebo manifestace.

Např. kočka byla spojována jednak s bohyní Bastetou, a jednak díky tomu, že útočí na hady, s hlavním slunečním bohem Reem, který musel noc co noc bojovat s hadem Apopem, ztělesněním všeho ne-řádu zvaného isfet. Úcta k posvátným zvir̃atům byla velmi oblíbená zejména v prvním tisíciletí pr. n. I.

Kromě zvir̃at se lze v egyptském náboženství setkat také s různými posvátnými rostlinami nebo stromy. Zástupci flóry však oproti posvátným 


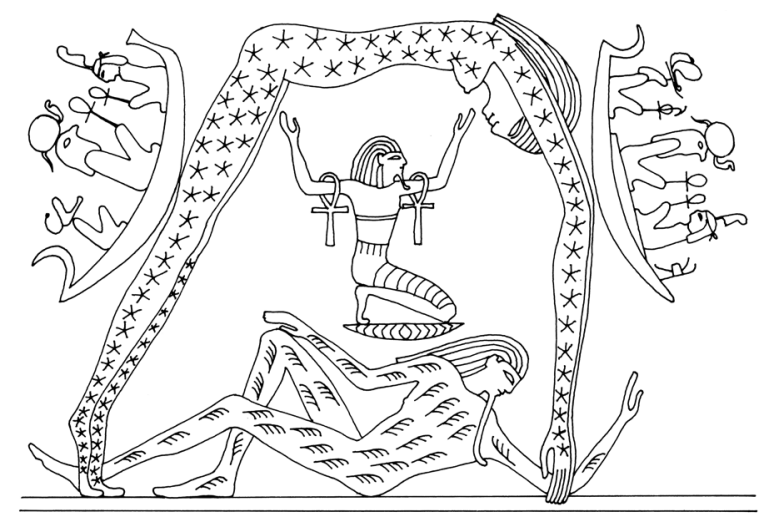

\section{Obrázek 1}

zvir̃atům měli poněkud jinou funkci. Spíše než projevem božstev se stávaly jejich atributy. ${ }^{147}$ Jen velmi malý počet rostlin byl v Egyptě zbožštěn prímo. V první řadě se jednalo o lotos a dále o jednu rostlinu, jejíż identifikace je dosti obtížná, a proto se o ní mluví jako o rostlině wng (obr. 2). Obě zmíněné rostliny se jako zbožštěné objevily již ve Staré řiši (cca 2700-2180 př. n. I.) a shodou okolností byly spojeny se slunečním kultem.

Príspěvek se tedy bude věnovat náboženskému významu lotosu a rostliny wng a časově se omezí na období Staré říše. Je však také nutné zahrnout i některé prameny z Raně dynastické doby (cca 3150-2700 př. n. I.). Přestože lotos hrál významnou roli v náboženských představách v podstatě po celou dobu existence staroegyptské civilizace, u rostliny wng tomu tak není. Ta je doložena pouze ze dvou uvedených období. Srovnání symbolických rolí obou těchto rostlin může přinést vysvětlení toho, proč zrovna dvě uvedené rostliny Egyptané zbožštili, na základě čeho byly spojovány se slunečním kultem nebo z jakého důvodu se s rostlinou wng setkáme pouze v nejstarších obdobích. Metodologicky se vychází zejména z Textů pyramid, nejstaršího souboru staroegyptských náboženských textů. ${ }^{148}$

147 Zibelius 1977, 659-660.

148 Pro překlady Textů pyramid viz např. Faulkner 1969; Allen 2005 nebo Carrier 2009. 


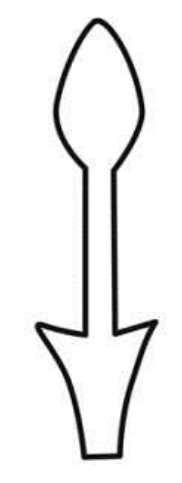

\section{Obrázek 2}

Tyto texty se poprvé objevují až v pyramidě panovníka Venise na konci 5. dynastie (vládnul přibližně ve 24. století př. n. I.), následně je používají panovníci a některé královny další 6 . dynastie (cca 24.-22. století př. n. I.). Texty pyramid jsou rozděleny na jednotlivá ř́kání, kterých je dnes okolo 800 a jež se dále dělí na paragrafy. ${ }^{149}$ Výzkum prezentovaný v tomto článku se pak zaměřuje na studium jak primárních, tak i sekundárních zdrojů a snaží se vyhledat a analyzovat doklady pro jednotlivé rostliny (viz ní̌e). Pramenná báze je však dosti nevyrovnaná, lotos se objevuje mnohem častěji.

\section{Lotos}

Ve starověkém Egyptě se vyskytovaly tři druhy lotosu, resp. správněji by se mělo hovořit o leknínech. ${ }^{150} \mathrm{~V}$ egyptologickém bádání je však zažité používání pojmu lotos a tento konsensus bude v príspěvku dodržen, avšak s vědomím, že nejde o zcela přesné označení. Z náboženského hlediska byl nejdůležitější modrý lotos, lat. Nymphaea caerulea, se zašpičatěnými okvětní lístky, s listy na okrajích hladkými a s nasládlou vůní. $V$ menší mî̃e se lze setkat i s lotosem bílým, lat. Nymphea

\footnotetext{
149 Viz Allen 2013. Odkazuje-li se tedy na nějaké říkání Textů pyramid, používá se anglická zkratka PT s číslem příslušného říkání a někdy, pokud je to nezbytné, přidává se i číslo paragrafu. Zmíněný úzus je dodržován i v tomto příspěvku.

150 Pommerening - Marinova - Handrickx 2010, 14.
} 
lotus, jehož okvětní lístky jsou oproti modrému lotosu zakulacené a listy vroubkované. Ani jejich vůně není stejná: bílý lotos voní ostře a silně. Po vpádu perských vojsk do Egypta v roce 525 př. n. I. se ke konci 6. století př. n. I. dostává do Egypta ještě jeden druh lotosu: Iotos ořechonosný, zvaný červený nebo indický, v latině Nelumbo nucifera, ale ten $\mathrm{s}$ ohledem na chronologické vymezení bude $v$ tomto príspěvku ponechán stranou. ${ }^{151}$ Staři Egyptané si žejmě byli rozdílů mezi jednotlivými druhy lotosu vědomi, což žejejmě bylo reflektováno i v jejich jazyce. Modrý lotos nazývali sšn, prípadně š̌šn, a bílý $n h b t .{ }^{152}$ Kromě toho, že lotosy byly okrasnými rostlinami, našly i praktické využití v každodenním životě: používaly se pro výrobu vonných mastí, také v lékařství a v neposlední řadě některé jeho části mohly sloužit jako potrava.

Ve staroegyptském slunečním kultu hrál významnou roli lotos modrý. Jeho květ se s východem slunce otvírá, sleduje pout tohoto tělesa po obloze, a když slunce zapadá za obzor, opět se uzavírá. Nutno podotknout, že bílý lotos reaguje na slunce obráceně: otvírá se se západem slunce a s ranním rozbřeskem se zavírá. Chování modrého lotosu je také hlavním důvodem, proč jej staří Egyptané spojili se slunečním kultem. Navíc střed jeho květu je zbarven dožluta, což mohlo Egyptanům připomínat žluté slunce na modrém nebi. Modrý lotos byl spojován s motivy znovuzrození slunce a zesnulých, dále s ranním svítáním, a díky tomu i s regenerací a novým životem. Podle jedné staroegyptské kosmogonie hrál roli i při stvoření světa, kdy z vod nehybného pra-oceánu vystoupal pra-lotos a na něm se poprvé mělo objevit slunce. Lotos se objevuje v souvislosti s množstvím bohů, např. s božstvy slunečního cyklu: Cheprim, Reem a s Atumem. S lotosem se lze setkat také u dalších bohů, např. u Iheje, boha hudby, u různých forem sokolího boha Hora nebo také u Hapiho, spojovaného s nilskými záplavami, a u memfidského Ptaha, patrona řemesIníků. Vyskytuje se také v souvislosti s některými bohyněmi: u mateřské Esety, patronky Dolního Egypta Vadžety, prípadně u kraví bohyně Hathory, která byla spojována s nebesy, láskou nebo

151 K lotosu ve starověkém Egyptě podrobněji viz Weidner 1985.

152 Podle Pommerening - Marinova - Handrickx 2010, 28. Hannig však uvádí š̌n jako výraz pro oba druhy lotosu a nhbt pro lotosové žezlo. Viz Hannig 2006, 831 a 446. 


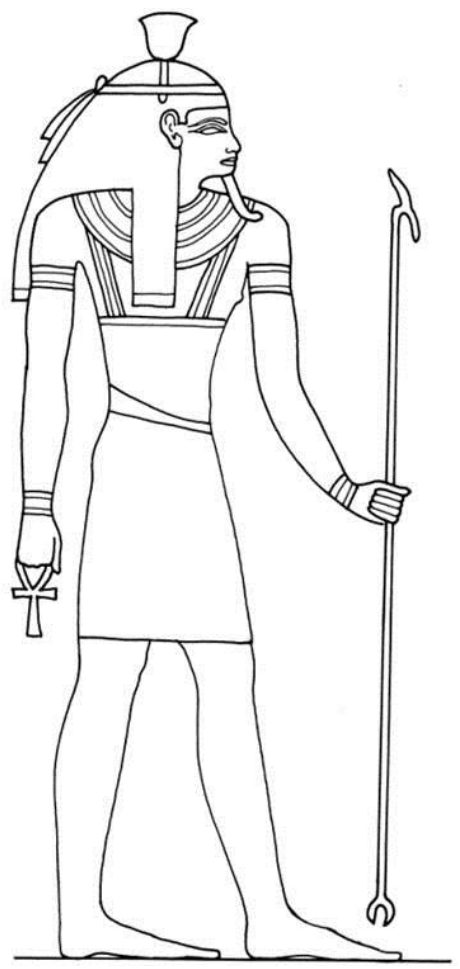

Obrázek 3

hudbou. Bohem modrého lotosu byl však Nefertem (obr. 3), mladistvé božstvo rodícího se slunce, který byl i válečnickým bohem a ochráncem zesnulých. V pozdější době byl dáván do souvislosti s parfémy, vonnými mastmi a oleji, což má jistě souvislost s př́ijemnou vưní modrého lotosu. ${ }^{153}$

Ještě je nutné podotknout, že ačkoli je lotos doložen ikonograficky a textově, doposud se nepodařilo identifikovat žádné makrozbytky této rostliny datované do Staré říše. ${ }^{154}$

153 K Nefertemovi viz např. Morenz - Schubert 1954; Munro 1968 nebo Leitz 2002, 221. K výskytu Nefertema ve Staré říši viz také Hlouchová 2013.

154 Pommerening - Marinova - Handrickx 2010, 17. 


\section{Lotos v Textech pyramid}

Zmínky o lotosu v Textech pyramid nejsou nikterak časté. Jedná se zhruba 0 třináct př́padů, i když ne v každém říkání je zřejmé, že jde o lotos, a ne vždy se vyskytuje ve spojitosti se slunečním kultem. Je také nutné rozlišovat, o jaký druh lotosu se jedná. Bílý lotos hlavně jako lotosové žezlo $(n h b t)$ je zmiňován v souvislosti s tím, že panovník přejímá vládu nad žijícími. ${ }^{155}$ Taková ríkání se vyskytují v podstatě ve všech pyramidách obsahujících texty. Jeden text se však ostatním zcela vymyká. Jedná se o rríkání PT 249, jež se nachází pouze v jediné pyramidě, u panovníka Venise. Umístěno bylo na západní stěnu předsíně. ${ }^{156}$ Kromě dalšího se v něm uvádí, že zesnulý panovník je Nefertemem, lotosovým květem u nosu Rea, když vychází z nebo na horizontu. Bůh Nefertem je zde tedy prímo spojen s květem lotosu, v tomto prípadě s největší pravděpodobností modrého, nebot' je zde použit výraz sššn. ${ }^{157}$ Protože jak božstvo, tak i květina měly spojitost se znovuzrozením, jedná se patrně o metaforické zachycení toho, že sluneční bůh Re vdechuje nový život. Je zde tedy patrná i souvislost se slunečním kultem.

\section{Lotos v soukromých hrobkách}

V některých soukromých staroříšských hrobkách se nacházejí vyobrazení zesnuých, kteří před nosem drží květ lotosu, jako např. v hrobce Meresanch III., vnučky panovníka Chufua, v Gíze nebo v hrobce vezíra Mereruky v severní Sakkáře. V jiných případech jej mohou pouze držet v ruce, ne před obličejem, což se vyskytuje např. v Chufuchafově hrobce v Gíze. ${ }^{158} 0$ významu těchto scén vzniklo několik teorií. Podle jedné z nich mají majitelé hrobek lotosový květ u nosu proto, že lotos má obsahovat alkaloidy navozující prríjemné pocity. ${ }^{159} \mathrm{~V}$ této souvislosti bylo provedeno několik analýz. Na základě výzkumu Davida J. Counsella se

\footnotetext{
155 Např. říkání PT 62, PT 213, PT 224, PT 225, PT, 665A, PT 674.

156 Piankoff 1968, 28.

157 Allen 2013 II: PT 249.

158 Výskytu těchto scén a jejich typovému roztřídění se věnovala Gabi Pieke. Viz Pieke 2006.

159 Harer 1985; Whitehouse 2009, 45.
} 


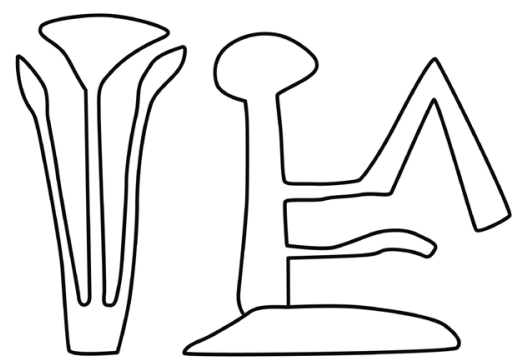

Obrázek 4

ale ukázalo, že lotos takové psychotropní látky neosahuje, ${ }^{160}$ a tudíž je nutné hledat význam těchto scén spíše v symbolickém kontextu. Mohlo by se jednat o ikonograficky zachycenou představu, která byla zmíněna dřive: podobně jako bůh Re $v$ Textech pyramid by mohli i hodnostáři vdechovat nový život. Pro srovnání je nutné ještě uvést, že scény jsou mnohem starší než textové zachycení této představy. Vyskytují se už v hrobkách ze 4. dynastie (cca 28.-26. století př. n. I.). Mohla by se případně nabízet ještě další teorie. V Nové říši (cca 1543-1080 př. n. I.) byl totiž lotos používán pro zápis slovního spojení $m 33^{\circledR}-h r w$ (obr. 4). ${ }^{161}$ Toto epiteton bývá překládáno jako „ospravedlněný”, což - zjednodušeně řečeno - označovalo zesnulého, který prošel nástrahami podsvětí a který se ospravedlnil ze svých skutků při posledním soudu v Síni dvou Maat. ${ }^{162}$. Přestože se toto epiteton objevuje až na začátku Střední říše (cca 1994-1797 př. n. I.), Ize spekulovat, jestli již zmíněné staroříšské scény nemohou odkazovat k podobné představě. Tento výzkum je ale teprve na svém počátku.

\section{Kosmetické nádobky ve tvaru lotosového květu}

Ještě pro doplnění dostupných pramenů pro lotos uved'me, že na některých pohřebištích z Raně dynastické doby byly v hrobech objeveny malé kamenné kosmetické nádobky ve tvaru lotosového květu. ${ }^{163}$ Zdá

\footnotetext{
160 Counsell 2008, 204-209.

161 Geßler-Löhr 1990.

162 K pojmu $m$ 3`-hrw viz např. Anthes 1954 nebo Beinlich 1980.

163 Petrie - Brunton - Murray 1923, 22.
} 
se nesporné, že lotos byl už tehdy spojován se znovuzrozením zesnulých. Avšak jestli již v té době byl lotos zbožštěn jako bůh Nefertem, se nedá určit. Z tehdejších písemných pramenů o něm neexistuje žádná zmínka.

\section{Rostlina wng}

Druhou posvátnou rostlinou slunečního kultu je tzv. rostlina wng, která představuje jednu z nejzáhadnějších rostlin starého Egypta. Je doložena pouze v textech, tzn. jenom jako značka hieroglyfického písma (viz obr. 2). Do posvátné sféry se dostala také díky tomu, že byla spojena s božstvem, které mělo stejné jméno jako rostlina (obr. 5). Jak rostlina, tak i bůh jsou docela neznámí a ani badatelé jim nevěnovali př́lišnou pozornost. ${ }^{164}$

\section{Wng ve 2. dynastii}

S rostlinou wng se lze poprvé setkat ve 2. dynastii (cca 2930-2700 př. n. I.). Některé kamenné nádoby z té doby nalezené v podzemních prostorách nejstarší Stupňovité pyramidy nesou nápis nswt-bjtj nbty Wng. ${ }^{165}$ Královské jméno Veneg je zapsáno pouze jednou značkou, a to rostlinou, jejíž fonetická hodnota byla určena až na základě Textů pyramid. Nswt-bjtj a nbty jsou dva tituly objevující se v královských titulaturách. Nswt-bjtj se překládá jako „král Horního a Dolního Egypta“, přičemž doslovný překlad by měl znít: „Ten, jenž patří ostřici a včele". Titul nbty znamená „Obě paní” a jsou tím míněny dvě ochranné bohyně: Vadžet pro Dolní Egypt a Nechbet pro Horní Egypt. Oba tituly odkazují na panovníkovu vládu nad oběma sjednocenými zeměmi. Samozřejmě mají ještě hlubší a propracovanější symboliku, ale ta ted' bude ponechána stranou. ${ }^{166}$

164 K předchozímu bádání a problematice psaní jména boha Venega viz Peterková Hlouchová v tisku.

165 Lacau - Lauer 1936, 6, 12, 16, 17; 1961, 53; 1965, 26; Kaplony 1973, Taf. 7/27; Kahl 1994, 354-355.

166 Podrobněji viz např. Beckerath 1984, 13-21. 


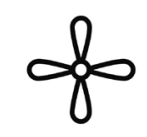

\section{MuM}

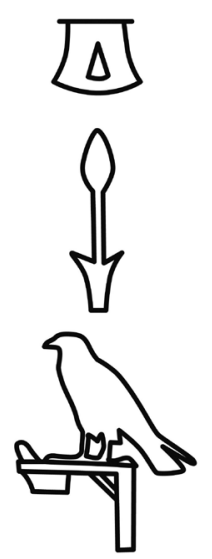

\section{Obrázek 5}

Lze tedy předpokládat, že nápis nswt-bjtj nbty Wng zmiňuje jednoho z králů 2. dynastie. Není jisté, jestli se jednalo o samostatného panovníka, ${ }^{167}$ nebo jestli šlo pouze o další jméno nějakého jiného krále 2. dynastie. Německý egyptolog Jochem Kahl se domnívá, že Veneg bylo další jméno panovníka Raneba, který tím, že přijal do svých královských jmen označení dvou egyptských božstev spojovaných se sluncem, jenom podtrhl svoji podporu slunečnímu kultu. ${ }^{168}$ Tato teorie je jistě na první pohled velmi přitažlivá, na druhou stranu ale lze proti ní spoustu věcí namítnout. Kahl totiž nevysvětlil, proč si Raneb vybral jméno božstva, které sice mělo sluneční aspekt, ale ve slunečním kultu jako takovém nebylo nijak významné. Neřešil ani tu otázku, jak je možné, že panovník, ačkoli byl považován za pozemské vtělení sokolího boha Hora, mohl mít zcela stejné jméno jako nějaké božstvo.

167 Viz např. Grdseloff 1944, 291; Beckerath 1984, 48, 173.

168 Kahl 2007, 14. 
Nabízi se možnost, že v Raně dynastické době nemusela být ještě rostlina wng zbožštěna a že tedy královské jméno neodkazuje k božstvu, ale pouze $\mathrm{k}$ rostlině nebo nějaké představě, která s ní byla spojována. Zajímavé také je srovnání jména Veneg s ostatními nbty jmény, resp. spiše epitety, ${ }^{169}$ panovníků té samé dynastie: Htp-nbty, Nj-ntr-nbty, Shm-jb-nbty Prj-m-m3 tr, Nbty-pr-jb=sn, HCj-shmwy-nbty, $H t p-n t r w y-j m=f$. Ani $v$ jednom prípadě se neodkazuje na žádné božstvo a vždy je nějakým způsobem podobné Horovu jménu daného panovníka. Navíc se nikdy nejedná o jednoslovné výpovědi, ale vždy o nějaká slovní spojení nebo dokonce věty. Královské jméno Veneg je $v$ tomto ohledu velmi výjimečné.

\section{Wng v Textech pyramid}

$\checkmark$ průběhu dalších príbližně pěti staletí se rostlina wng v pramenech neobjevuje. Znovu se vyskytla až na začátku 6. dynastie v náboženských textech, konkrétně ve dvou nebo možná snad ve třech řikáních Textů pyramid, kde vystupuje pouze ve jméně boha. Rostlina není nikdy zmíněna samostatně. První z nich, PT 363, § 607, je doloženo $\checkmark$ Textech pyramid panovníků Tetiho, Pepiho I., Merenrea a Pepiho II., a také u královny Anchnespepi II. V nejstarším souboru Textů pyramid, u Venise, však ani jedno ríkání zmiňující Venega není.

Zato však do Venisova souboru Textů pyramid, jak již bylo zmíněno, bylo zahrnuto ríkání zmiňující Nefertema (viz vy̌še). V prvním říkání rostlina wng vystupuje jako stejnojmenné božstvo, které je zde označováno za Reova následovníka. Re má Venega prevést na druhou stranu (myslí se nebes). Je však zarážející, že hieroglyf pro rostlinu wng se $\checkmark$ tomto říkání vyskytuje pouze $v$ Tetiho pyramidě. U Pepiho I. byla použita značka, jež se používala obecně jako determinativ nějaké rostliny. Jestli v ostatních pyramidách bylo Venegovo jméno psáno pomocí jeho rostliny, bohužel není známo, protože ríkání PT 363 je v těchto prípadech dochováno velice fragmentárně.

Dalši ríkání uvádějící rostlinu wng bylo použito ve čtyřech pyramidách: u Pepiho I., Merenrea, Pepiho II. a u královny Neit. Hovoří se

169 Degreef, osobní sdělení. 
v něm o tom, že zesnulý panovník se ztotožňuje s Venegem, čímž jsou oba označeni za syna Reova. 0 Venegovi se tvrdí, že podpírá nebesa, vede zemi a soudí bohy. V prvních třech prípadech je jméno boha psáno pomocí rostliny wng, ale v posledním prípadě byla použita zcela jiná značka $\mathrm{ks}^{170}{ }^{170}$ Jedná se o kostěnou špičku harpuny. Nejde tedy vůbec o rostlinu. Otázkou zůstává, proč byla tato značka použita. Texty v Neitině pyramidě jsou vytesány dosti ledabylým způsobem, proto by se dalo předpokládat, že řemeslník/ci, který/kteří tesal/i texty v pyramidě si značku spletl/i a udělali chybu. Tato problematika však vyžaduje podrobnější zkoumání.

Posledním ř́káním, kde je pravděpodobně uveden bůh a jeho rostlina, je PT 667B, použité ve stejných pyramidách jako předchozí text. Podle amerického egyptologa Jamese P. Allena jsou zde zmíněni čtyři Venegové podpírající nebesa ve čtyřech světových stranách. ${ }^{171} \mathrm{Na}$ interpretaci této značky se však neshodují všichni badatelé. Ačkoli jsou evidentní nepatrné rozdíly, značky velmi připomínají rostlinu wng, a proto by se dalo souhlasit s Allenovou interpretací.

\section{Identifikace rostliny}

Identifikace toho, o kterou rostlinu se jedná, je velmi obtižná, i když by jistě pomohla odkrýt minimálně Venegovu souvislost se slunečním kultem. $Z$ botanického hlediska se na první pohled může jednat téměř o cokoli: není ani jasné, zda jde o celou rostlinu nebo pouze o její část, jestli značka zachycuje poupě nebo rostlinu již ve stadiu dospělosti. Pro určení rostliny wng mohou trochu napovědět zmínky v Textech pyramid. Podle toho, co bylo zmíněno výše, by se mohlo jednat o rostlinu, která nějakým velmi významným způsobem reaguje na slunce, podobně jako modrý lotos. A na základě toho, že čtyři takové rostliny měly podpírat nebesa, by se dalo usuzovat na nějaký relativně vysoký a silný druh. Přestože se zcela stejná značka později již neobjevuje, některé mladší ikonografické prameny by též mohly být nápomocny při identifikaci rostliny wng. Dalo by se uvažovat o tom, že se může jednat

\footnotetext{
170 Collombert, v př́pravě.

171 Allen 2005, 394.
} 
o poupě nějaké rostliny, např. lotosu nebo papyru. Pokud by skutečně šlo o poupě, znamenalo by to, že bůh Veneg byl mladistvým božstvem, podobně jako Nefertem. Je nutné vzít v potaz také tu možnost, že značka zobrazuje dospělou rostlinu s protáhlým květenstvím.

$V$ tom případě by se dalo uvažovat napríklad o rostlině rodu Kniphofia, která je v současnosti poměrně oblíbenou zahradní rostlinou, a to zejména díky jejím barvám. Existuje několik druhů této rostliny a ty se vyskytuji ve žluté, zelené, oranžové nebo červené barvě, což by jistě mohlo implikovat slunce. Rostliny rodu Kniphofia dorůstají výšky 60-150 cm.

V současnosti některé její druhy rostou divoce na území dnešního Súdánu a Etiopie. ${ }^{172}$ Dalo by se tedy spekulovat o tom, že nějaká podobná rostlina se mohla ve starověku vyskytovat i v nilském údolí a se změnami klimatu odsud vymizela. Nicméně ale žádná rostlina tohoto druhu ze starého Egypta doložena není. Zajímavé však je, že se jí lidově ř́ká Kleopatřina jehla.

Na základě podobného květenství by v úvahu mohl přicházet i čirok dvoubarevný, lat. Sorghum bicolor, který se dnes pěstuje jako obilovina v mnoha oblastech po celém světě. Symbolický význam čiroku je doložen pro merojskou Núbii, ${ }^{173}$ avšak pro starý Egypt se zatím nepodařil prokázat. Na egyptském území byl čirok objeven v Nabtě a v oáze Farafra. Makrozbytky byly datovány do období cca 8000 BP a ukázalo se, že se jedná o divoký čirok, Sorghum arundinaceum, ${ }^{174}$ který se však spiše podobá travině. Takže se zdá, že s největší pravděpodobností nelze rostlinu wng ztotožnit s čirokem.

Přesnému určení rostliny wng mohou napomoci hieroglyfické značky zaznamenané na třech artefaktech, které jsou v současnosti vystaveny ve sbírkách Egyptského muzea v Káhiře. Na nedokončené části nepravých dveří hodnostáře Centiho, ${ }^{175}$ na boční straně sarkofágu

172 http://www.ville-ge.ch/musinfo/bd/cjb/africa/details.php?langue=an\&id=191836 (26. 5. 2015).

173 Fuller 2014, 170-172.

174 Lucarini 2006, 463.

175 Journal d'entrée 72135. Manuelian 2002. 
Anchnespepi III. a na jedné plaketce z doby vlády Pepiho II. je rozpoznatelná značka pro papyrus ( $w 3 \underline{d}$ ) s listy ve spodní části, podobně jako u rostliny wng. 0 identifikaci této rostliny nemǔže být pochyb, protože $\checkmark$ posledních dvou prípadech byla použita pro zápis jména bohyně Vadžet. Na základě toho se jeví jako nejpravděpodobnější, že rostlina wng je vlastně papyrovým poupětem.

\section{Závěr}

Jak bylo možné vidět, ve Staré řšši byly se slunečním kultem spojeny dvě hlavní rostliny, které byly zároveň zbožštěny. První z nich, lotos modrý, je poměrně dobře známá květina a její význam se udržuje po celou dobu existence staroegyptské civilizace. Spojení lotosu se znovuzrozením je reflektováno jak v královských, tak i nekrálovských pramenech. $\mathrm{V}$ panovnickém prostředí je ještě zdůrazněna i spojitost s vládou.

Oproti tomu druhá rostlina, wng, se v pramenech objevuje pouze v prvních dvou velkých obdobích sjednoceného státu a jenom v pramenech královské provenience. Ve většině prípadů se vyskytuje personifikována v podobě stejnojmenného boha. Zdá se, že rostlina wng žejmě zobrazuje poupě papyru. Stále ale není jasné, proč se v pozdějších obdobích nevyskytuje ani rostlina, ani božstvo. Zůstává otázkou, jestli to Ize přikládat na vrub fragmentárnosti dochovaných pramenů, změnám v náboženských představách a v jazyce, prípadně jiným faktorům, které stále zůstávají skryty. Bohužel však za současného stavu pramenů nelze najít uspokojivé odpovědi. 


\section{Literatura}

Allen, James P. 2005: The Ancient Egyptian Pyramid Texts, Atlanta.

2013: A New Concordance of the Pyramid Texts, vol. I-VI, Brown University.

Anthes, Rudolf 1954: „The Original Meaning of $m 3^{\mathrm{C}}$ hrw ${ }^{\prime}$, Journal of Near Eastern Studies 13, 21-51.

Beckerath, Jurgen von 1984: Handbuch der ägyptischen Königsnamen, Berlin.

Beinlich, Horst 1980: „Maca-cheru“, in: Wolfgang Helck - Wolfhart Estendorf (eds.), Lexikon der Ägyptologie 3, Wiesbaden, 1107-1110.

Carrier, Claude: 2009 Textes des pyramides de I'Égypte ancienne I-VI, Paris.

Counsell, David J. 2008: "Intoxicants in ancient Egypt? Opium, nymphaea, coca and tobacco", in Rosalie David (ed.), Egyptian Mummies and Modern Science, New York, 195-215.

Faulkner, Raymond 0.: 1969 The Ancient Egyptian Pyramid Texts, Oxford.

Fuller, Dorian 0. 2014: „Agricultural Innovation and State Collapse in Meroitic Nubia. The Impact on the Savannah Package", in: Chris J. Stevens - Sam Nixon - Mary Anne Murry - Dorian 0 Fuller (ed.), Archaeology of African Plant Use, Walnut Creek, California, 165-177.

Geßler-Löhr, Beatrix 1990: „Zur Schreibung von m3-hrrw mit der Blume", Göttinger Miszellen 116, 25-43.

Grdseloff, Bernard 1944: „Notes d'épigraphie archaïque. 4. Le roi Wenig de la Ile dynastie", Annales de Service des antiquités de l'Égypte 44, 288-292.

Hannig, Rainer 2006: Großes Handwörterbuch: Ägyptisch-Deutsch (2800-950 v. Chr.): Die Sprache der Pharaonen, Mainz.

Harer, W. Benson 1985: „Pharmacological and biological properties of the Egyptian lotus", Journal of the American Research Center in Egypt 22, 49-54. 
Hlouchová, Marie 2013: "Méně významná starořišská božstva se slunečními aspekty: Veneg a Nefertem", Pražské egyptologické studie XI, 44-50.

Kahl, Jochem 1994: Das System der ägyptischen Hieroglyphenschrift in der 0.-3. Dynastie, Wiesbaden.

2007 "Ra is my Lord». Searching for the Rise of the Sun God at the Dawn of Egyptian History, [Menes 1], Wiesbaden.

Kaplony, Peter: 1973: Beschriftete Kleinfunde in der Sammlung Georges Michailidis. Ergebnisse einer Bestandsaufnahme im Sommer 1968, Istanbul.

Lacau, Pierre Lucien - Lauer, Jean-Philippe 1936: La pyramide à degrés. Tome 1. Texte, Le Caire.

1961: La pyramide à degrés. Tome 4. Inscription gravées sur les vases. Fasc. II, Le Caire.

1965: La pyramide à degrés. Tome 5. Inscription à l'encre sur les vases, Le Caire.

Leitz, Christian 2002: Lexikon der ägyptischen Götter und Götterbezeichnungen, Bd. IV, [Orientalia Lovaniensia analecta 113], Leuven.

Lucarini, Giulio 2006: "The use and exploitation of sorghum and wild plants in the Hidden Valley village (Farafra Oasis Egypt)", in: Karla Kroeper - Marek Chodnicki -Michał Kobusiewicz (ed.), Archaeology of Early Northeastern Africa. In Memory of Lech Krzyźaniak, Poznań, 463-478.

Manuelian, Peter Der 2002: „Unfinished Business: The Giza Tablet of Tjenti (JE 72135)", in: Mahmoud Eldamaty - Mai Trad (ed.), Egyptian museum collections around the world 2, Cairo, 777-790.

Morenz, Siegfried - Schubert, Johannes 1954: Der Gott auf der Blume. Eine ägyptische Kosmogonie und ihre weltweite Bildwirkung, Ascona.

Munro, Peter 1968: „Nefertem und das Lotos-Emblem”, Zeitschrift für Ägyptische Sprache und Altertumskunde 95, 34-40. 
Peterková Hlouchová, Marie v tisku: "The god Weneg and the wng-plant in the Old Kingdom", Proceedings of the Old Kingdom Art and Archaeology Conference, Warsaw.

Petrie, William M. F. - Brunton, Guy - Murray, Margaret A.: 1923 Lahun II, London.

Piankoff, Alexandre 1968: The Pyramid of Unas, [Bollingen Series 40.5], Princeton.

Pieke, Gabi 2006: „Der Grabherr und die Lotosblume. Zu lokalen und geschlechtsspezifischen Traditionen eines Motivkreises", in: Miroslav Bárta (ed.), The Old Kindom Art and Archaeology. Proceedings of the Conference held in Prague May 31 - June 4, 2004, Prague, 259-280.

Pommerening, Tanja - Marinova, Elena - Handrickx, Stan 2010: „The Early Dynastic origin of the water-lily motif", Chronique d'Égypte 85, 14-40.

Weidner, Stephan 1985: Lotos im alten Ägypten. Vorarbeiten zu einer Kulturgeschichte von Nymphaea lotus, Nymphaea coerulea und Nelumbo nucifera in der dynastischen Zeit, Pfaffenweiler.

Whitehouse, Helen 2009: Ancient Egypt and Nubia in the Ashmolean Museum, Oxford.

Zibelius, Karola 1977: „Götter, Pflanzen-“, in: Wolfgang Helck - Wolfhart Westendorf (eds.), Lexikon der Ägyptologie II, Wiesbaden, 659-660. 


\section{Michaela Śmiejová}

\section{Emonská proklínací destička: Defixiones jako fenomén}

Tzv. proklínací destičky jsou pro nás jako magická praktika zajímavé především ze dvou důvodů: Považujeme je jak za epigrafický, tak archeologický zdroj poznání. Druhým důvodem je, že nám více než kterákoli jiná praktika ukazují na myšlení lidí v antice. Tento druh proklínání přišel do římské říše z východu. Velmi oblíbená byla tato praktika v Řecku, kde tyto destičky nazýváme $\kappa \alpha \tau \alpha \delta \varepsilon \sigma \mu o \iota$. Do Itálie se ž̌ejmě dostala v průběhu druhého století před Kristem, jelikož neznáme starších nálezů. ${ }^{176}$ Latinským destičkám dnes říkáme defixiones. Na západ se ž̌ejmě poprvé dostávají s profesionály, ${ }^{177}$ následně se pak šrî́i mezi lidmi. Ač byl tento fenomén velice oblíbený, stále se jednalo o zakázané konání. Stejnou situaci vidíme i v Řecku, kde magie byla postavena mimo polis a byla považována za antisociální. ${ }^{178}$

Většina kleteb je psána na olověné destičce za použití stylu. Tyto destičky jsou poměrně malé, často bývají složené a propíchnuté železným hřebíkem, jedná se o jakýsi druh fixace. Př́kladem tohoto konání mưže být destička s označením DT 49, ${ }^{179}$ která byla objevena v Athénách. Kletby se obvykle skládají pouze ze seznamu jmen, občas za využití

\footnotetext{
176 Tato informace vychází z mých statistik podle Urbanová 2014.

177 Velmi zajímavým nálezem dokládajícím existenci profesionálů v tomto oboru je „poklad“ z Tell Sandahannah, kde bylo nalezeno veliké množství tzv. voodoo panenek, které stejně jako destičky jsou vytvářeny z olova a jsou svázány (ruce, nohy). Více informací v Gager 1999, fig. 23.

178 Petropoulos 2008, 4.

179 Audolent 1904.
} 
magických proklínacích formulí. ${ }^{180}$

Tento způsob proklínání obvykle dělíme podle situace, ve které byl použit. Řecké proklínací destičky byly užívány především na záležitosti okolo lásky, soupeření ve sportu nebo práci, nebo u soudních procesů. ${ }^{181}$ Právě poslední zmiňovaný způsob patří k nejrozšîrenějším v Itálii. Destička z Emony sem patří taktéž.

Obvykle bývají uloženy ve vodě, hrobu nebo svatyni. Známe velké depozity kleteb ze studní na athénské Agoře, především z období rímského. ${ }^{182}$ Velmi časté je i užití čerstvého hrobu, např. v PGM je zaklínadlo, které doporučuje uložit destičku proti vozatajovi do hrobu někoho, kdo zemřel předčasně. ${ }^{183}$ Mrtvé tělo mohlo být bráno také jako jakýsi svědek kletby. ${ }^{184}$ Pokud se jedná o svatyně, ty byly oblíbené především v provinciích, př́kladem může být Aquae Sulis nebo Uley v Británii, či Mogontiacum v Germánii Superior.

Zaznamenala jsem 72 proklínacích destiček z Itálie, pokud nepočítáme právě tu emonskou, která obvykle bývá zařazována do Pannonie Superior. ${ }^{185}$ Z toho 19 je datováno do prvního nebo druhého století našeho letopočtu.

\section{Colonia Iulia Emona}

Nyní bych ráda uvedla pár slov k historii Emony, tedy dnešní Lublaně. V letošním roce Emona slaví dvoutisící výročí. Ale podle mýtů je mnohem starší. K této oblasti se vztahuje výprava Argonautů, kdy zde žil drak, kterého láson porazil. Tento drak se stal symbolem Lublaně.

Na území dnešní Lublaně se rozkládaly dva vojenské tábory doby římské. Na začátku prvního století našeho letopočtu zde byla ustavena Colonia Iulia Emona. Podle nápisu, který zde byl nalezen, máme

\footnotetext{
180 Příkladem takovýchto destiček může být DTA 1 nebo SGD 48 nalezené v Athénách, či DFX 5.1.6/1 z Rossdorfu (Germania Superior).

181 Více v Gager 1999.

182 Jordan 1985, 198-252.

183 PGM IV. 2145-2240, v překladu H. Martina, Jr. (v GMP).

184 Eidinow 2007, 150.

185 Kropp 2008; Urbanová 2014.
} 
nejzazší datum mezi druhou polovinou roku 14 a začátkem roku 15 našeho letopočtu. Za Augusta a Tiberia byla vystavěna velká veřejná budova, mohlo se snad jednat o městské zdi a věže. Obyvatelé původně přišli ze severní Itálie. Známe jména 30 rodin, které zde sídlily, z tohoto čísla 13 bylo právě ze severní Itálie.

Emona za římské říše fungovala od 1. do 5. století. Plán města byl pravidelný s cloacou. Kolem města vedly hradby s věžemi a dvěma př́kopy, z nichž jeden byl naplněný vodou. Velmi důležitou spojnicí byla řeka Ljubljanica, spojená s božstvy Laburem a Aequornou. ${ }^{186}$

\section{Proklínací destička z Emony}

Kletba z Emony byla objevena roku 1911 pod vstupem do domu, ${ }^{187}$ který je označován jako Dům Oraee, který nese číslo VI. ${ }^{188}$ Jméno dal tomuto domu oltář (obr. 1), ${ }^{189}$ který se zde našel a který je datován do druhého století našeho letopočtu. Nese tento nápis:

ORAE(A)E/ EX IMP(ERIO)/ M(ATRI?) D(EORUM?) M(AGNAE?)/ L(IBENTIS) A(NIMO) P(OSUIT) ${ }^{190}$ nebo ORAE(A)E/ EX IMP(ERIO)/M(ATRIS?) D(EUM?) M(AGNAE?)/ L(UCIUS) A(---) P(---). ${ }^{191}$

Stále se diskutuje o tom, co přesně má Oraea znamenat. Podle Cuntze se jedná o jméno otroka, respektive otrokyně, která darovala tento oltár. ${ }^{192}$ To však žrejmě nebude pravdou, jelikož se toto jméno nachází na začátku nápisu, chybí tedy jiné celé jméno dárce. ${ }^{193}$ Druhým názorem je, že se jedná o zkomolené přízvisko Mater Magna:194 Oreia. To pochází z frýžského označení pro „Matku hor', řecky Meter oreia. Pokud je druhý názor správný, mǔže to naznačovat, že tabulka byla

\footnotetext{
186 Županek 2010.

187 Cuntz 1913, 204.

188 Schmid 1913, 104-114.

189 Dnes se nachází v Museum of Ljubljana pod inv. č. 83.

190 Selem 1980, 198; Cuntz 1913, 204; AlJug I, 73-74.

191 Šašel Kos 2010, 248; RINMS 21 = AIJ 162.

192 Cuntz 1913, 204.

193 Selem 1980, 198.

194 Šašel Kos 2008, 690.
} 


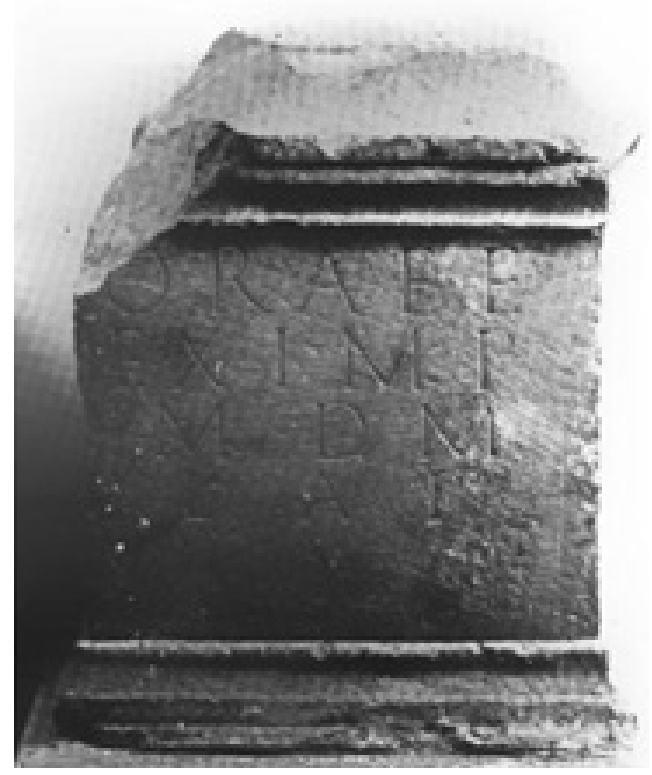

\section{Obrázek 1}

zamýšlena pro Mater Magna Oreia. To může být velmi zajímavé, jelikož jedinou další lokalitou zasvěcenou Mater Magna, kde byly objeveny proklínací destičky, je chrám Isidy a Mater Magna v Mogontiacu. Zde bylo objeveno na 34 destiček. Chrám byl vystavěn za vlády Vespasiána, jak nám dokládá monumentální nápis s dedikací. ${ }^{195}$ Bohyně byla v Římě velmi dobře známá již z konce třetího století před naším letopočtem. ${ }^{196}$

Za běžných okolností by kletba byla objevena ve vodě nebo pod oltářem, jak je tomu v Mogontiacu. To, že byla objevena v domě, je tedy velice nezvyklé, především jelikož si podle dispozice a půdorysu můžeme být jisti, že se nejedná o chrám. Z Itálie známe jen jeden jediný další případ uložení v domě, ovšem jedná se o Domus Liviae na Pallatinu. Tamní kletba je datována do první poloviny prvního století. ${ }^{197}$

\footnotetext{
195 Více v: Gordon 2013; Chalupa 2011.

196 Chalupa 2011, 238.

197 Urbanová 2014, 349.
} 


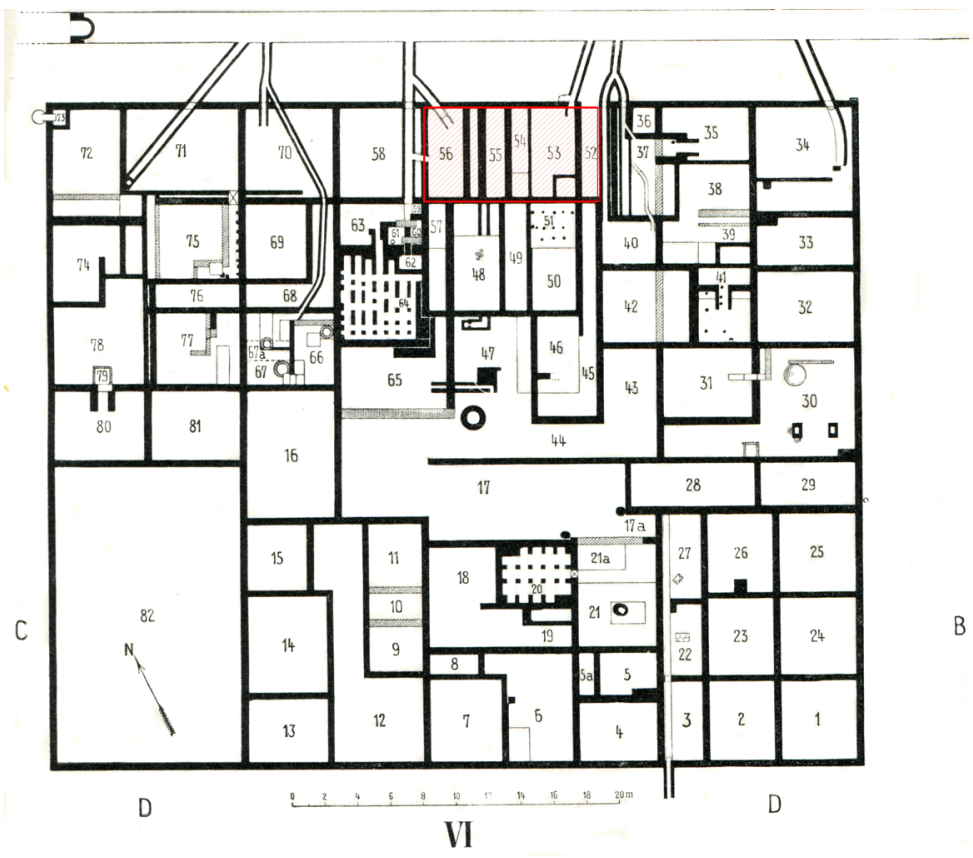

Obrázek 2

Konkrétní místo uložení je pod vchodem do místností 52-56 ${ }^{198}$, jak Ize vidět na plánku (obr. 2). Jednalo se rovněž o vstup ze severní strany do celého domu. ${ }^{199}$ Destička byla objevena v nejspodnější vrstvě, překrytá vrstvou uhlíků, pozůstatku po požáru. ${ }^{200} \mathrm{~V}$ místnostech 48, 52 a 56 vedl kanál pro odvod deštové vody. V místnosti 53 se nacházela jáma 0 rozměrech $1,4 \times 1,4 \mathrm{~m}$, na jejím dně se nacházely artefakty augustovského období. $V$ místnostech 55 a 56 byly objeveny mince z pozdějších období, konkrétně Constans, Konstantin II. a Valentinian I. Podle Schmida byly místnosti 52-56 zbudovány v augustovském období (obr. 3). Konec této fáze je určen požárem z roku 238. ${ }^{201}$

\footnotetext{
198 Cuntz 1913, 205.

199 Schmid 1913, 105.

200 Cuntz 1913, 205.

201 Schmid 1913, 114.
} 


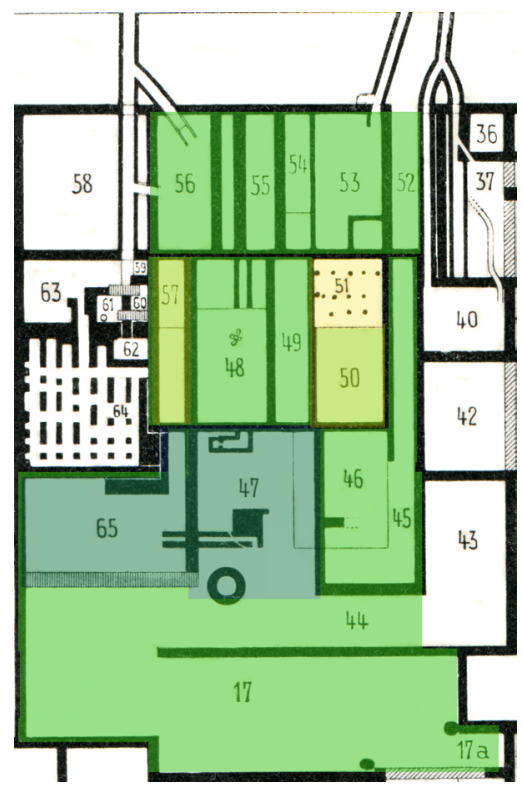

Obrázek 3

Rozměry destičky činí: 55 mm na výšku, 58 mm na šĩrku v horní části a $67 \mathrm{~mm}$ v dolní. Tloušt'ka kovu se pohybuje mezi 2,5 a $3 \mathrm{~mm}$. V levém dolním rohu byla destička poničena, jak lze vidět na obr. 4. Povrch přední strany byl podle Cuntze leštěn. Místy jsou vidět menší prohlubeniny vzniklé později, pravděpodobně požárem. ${ }^{202}$ Zadní strana nebyla leštěna. ${ }^{203}$

Text je ve formě kurzívy (obr. 5); podle Cuntze se jedná o pompejskou kurzívu, která datuje destičku do období raného císařství. ${ }^{204}$ Kurzíva byla užívána pro každodenní potřebu, vznikla z kapitálek a užívali ji především obchodníci, ale také jí bylo psáno v soukromé korespondenci, privátních dokumentech, ale také ji nalezneme na mnoha destičkách. Antická římská kurzíva byla užívána do třetího

\footnotetext{
202 Cuntz 1913, 205.

203 Z Cuntz, 1913. Bohužel fotografie zadní strany není uveřejněna.

204 Cuntz 1913, 206.
} 


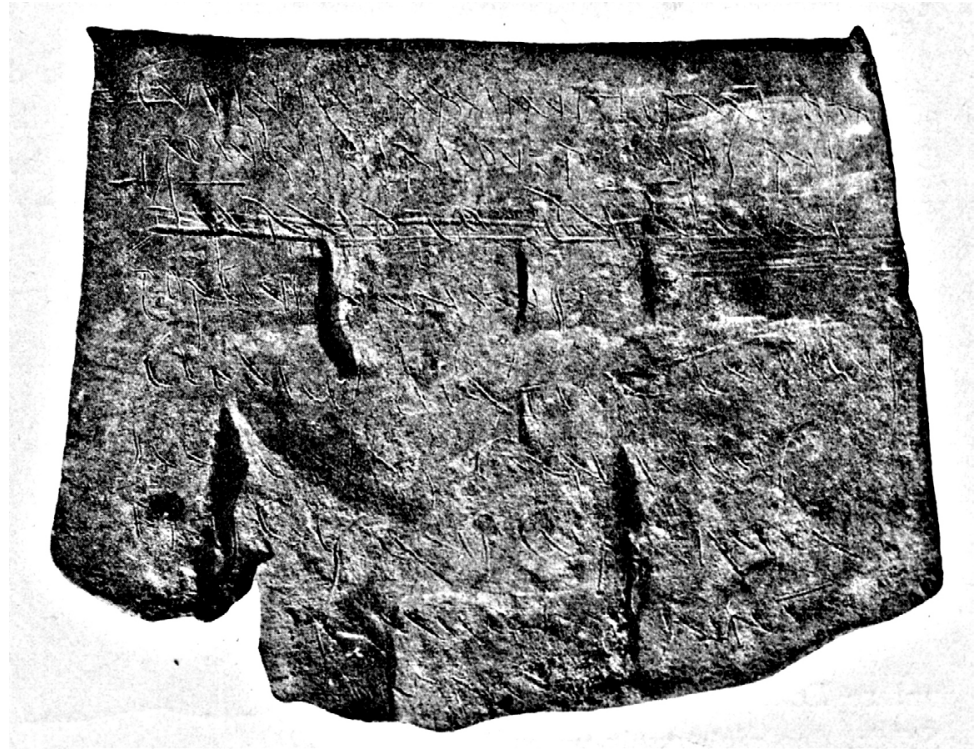

Obrázek 4

století, bývá jí přezdíváno pompejská podle mnoha nálezů z Pompejí a Herkulanea. ${ }^{205} \mathrm{Na}$ destičku bylo psáno pevným, ale pružným nástrojem. ${ }^{206}$ Obvykle byl užíván bronzový stylus k psaní kleteb do olova, ${ }^{207}$ jak to také navrhuje PGM, kdy je doporučováno, aby bylo vzato olovo z trubek s chladnou vodou a z toho pak vytvořena destička, na kterou se napíše bronzovým stylem... ${ }^{208}$ Proto si myslím, že tím nástrojem byl právě bronzový stylus.

Urbanová a Kropp datují destičku do druhé poloviny prvního století. ${ }^{209}$ Já bych raději volila první polovinu, kvưli kurzívě a především nálezům z místností, kde byla nalezena a faktu, že to bylo v nejnižší vrstvě. Proto myslím, že i defixio je augustovská.

\footnotetext{
205 Marcos 2014,13.

206 Cuntz 1913, 206.

207 Gager 1999, 4.

208 PGM VII 396-404, v překladu R. F. Hocka.

${ }^{209}$ Urbanová 2014, 363; Kropp 2008, 8.2/1.
} 


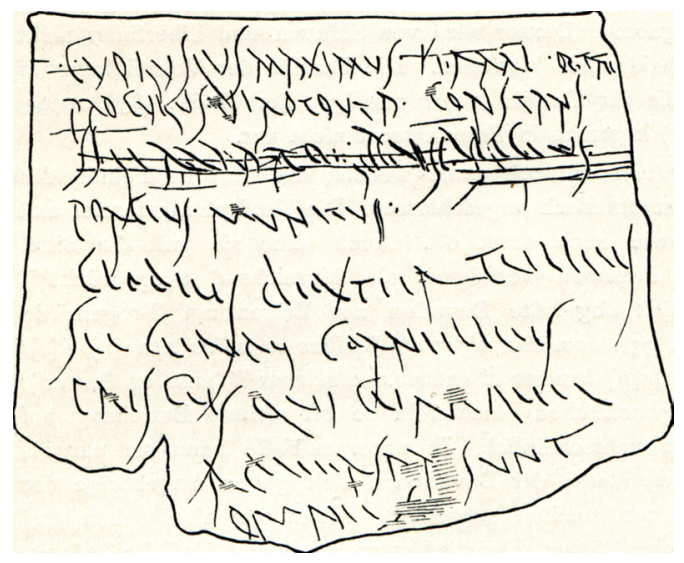

Obrázek 5

Nyní k textu samotnému.

Transkripce:210

C(aius) Volusius Maximus, Firmi Optati Proculus, Virotouta, Constans, servi atque publicius Porcius Munitus, Clodius Dexter, Tullius Secundus, Cornellius Priscus, quicumque adversary(ii) sunt omnes.

Překlad:

C(aius) Volusius Maximus, Firmi Optati Proculus, Virotouta, Constans, otroci a také publicius Porcius Munitus, Clodius Dexter, Tullius Secundus, Cornellius Priscus, a všichni (mí) nepřátelé. ${ }^{211}$

Tato kletba je označována za justiční. ${ }^{12}$ „Anglické termíny 'judicial prayers', později 'prayers for justice', byly uvedeny Henkem Versnelem (Leyden) před 30 lety," jak uvádí Gordon. ${ }^{213}$

Jedná se o seznam pravděpodobně osmi lidí - sedmi mužů a jedné ženy. Pouze jeden muž má kompletní nomenklaturu, pak jsou zmiňováni

\footnotetext{
210 Text převzat z Urbanová 2014, 363.

211 Oponenti, rivalové atd.

212 Kropp 2008; Urbanová 2014.

213 Gordon 2013, 266. Konkrétní rok vydání je 1986.
} 
tři otroci a čtyři propuštěnci. Jméno Volusius je zmiňováno Cuntzem na jiném nálezu z Emony, ${ }^{214}$ konkrétně CIL III 14354 $4^{17}$. Já nalezla ještě jednu stélu s kompletním jménem Volusiovým z Dalmácie, konkrétně z Vavarie: HD034393. ${ }^{215}$ Funerální stéla je datována do prvního století. Firmi optatije spojováno s otroky, prípadně propuštěnci. Obvykle nejsou tato označení tak blízko u sebe, ale existuji i výjimky, jako je ILJug0163, kdy mezi tato dvě slova je postaveno pouze et. Iméno Virotouta je keltského pưvodu. ${ }^{216}$ Jméno by mělo znamenat "muž ${ }^{217} z$ kmene". Není pochyb, že se jedná o jméno ženské. Potîz je se jménem Publicius, kde čtení není jisté. Podle Cuntze se jedná o jméno obecního otroka. ${ }^{218}$

První tři rádky jsou úmyslně podtržené na jejich začátcích a pod CO ve jméně CONSTANS. Jejich úmysl je ž̌ejmý, jelikož v místě dotyku s písmeny jsou pod nimi. Rovněž rozmezí mezi řádky je zhruba stejné. Zřejmě byly vyhotoveny kvüli malým rozměrưm tabulky, tak aby se vše vešlo. Později již nebyly zapotřebí, když si byl pisatel jistý, že se vejde. Mezi slovy jsou malé mezery. Vytvořila jsem typologii písmen za použití kresby Cuntze. ${ }^{219}$

0 je velice zajímavé, jelikož u tř́ typů je zkřriženo dole, u jednoho typu pak nahoře. Na rádcích 5 a 6 vidíme úplně rozdílný typ s otevřenou spodní částí. Pro $E$ jsou zde užity dvě rovnoběžné linie. Rozdíl mezi $A$ a $R$ je $v$ delš́ linii, která je u $A$ vtočena dovnitř. Když se podíváme na poslední typ $V / U$, uvidíme jistou podobnost $s E$, ale je více zatočeno, jako když je psáno ve spěchu. $V$ textu nalezneme nejméně dvě ligatury: $O$ a $P$ ve slově OPTATI a $U$ se $S$ v SECUNDUS. Č́m si nejsem př́liš jistá, je $B$, které není typické kurzivní, spiše se podobá $A$ nebo $R$, možná i ligatuře s T. Mǔžeme však vzít v úvahu i podobně vypadající $B$ z DTM 1 nebo DTM 29. ${ }^{220}$

\footnotetext{
${ }^{214}$ Cuntz 1913, 208; stejně tak AIJ 198. Fotografie je k vidění v Heidelbergské databázi pod označením F008657.

215 Epigraphische Datenbank Heidelberg.

216 Je uvedeno na nápise z Nemausis (Nîmes) z prvního století: CIL XII 3802.

217 Zde v ženském tvaru, tudíž „žena”.

218 Cuntz 1913, 207.

219 Cuntz 1913, 207.

220 Blänsdorf 2012.
} 


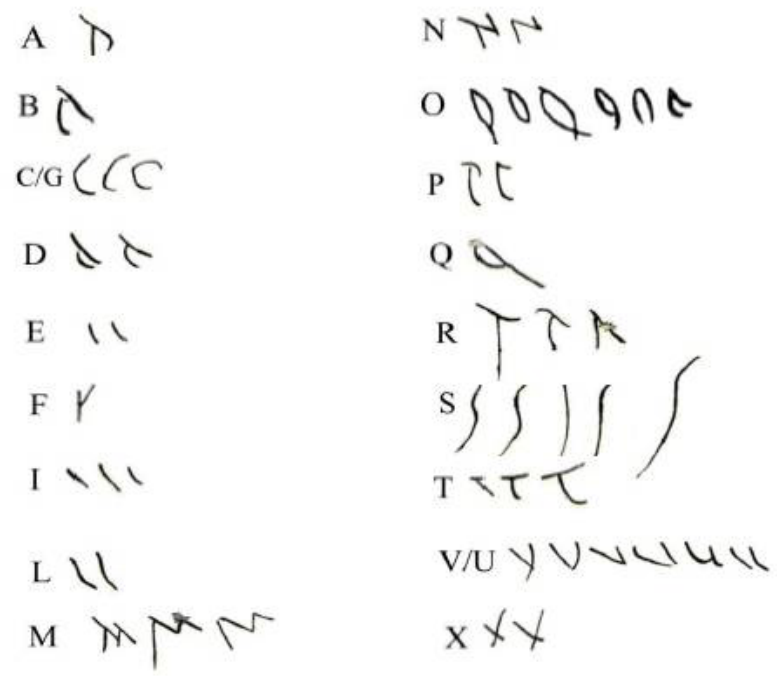

Obrázek 6. Typologie písmen

Velmi problematický je třetí řádek, zvláště pak jeho druhá polovina. Podle kresby, kterou publikoval Cuntz, a mé typologie, je zřejmé, že se zde nachází více písmen, než je ve slově PUBLIUS. Podle mého názoru je možné, že se nejedná o jedno slovo, ale o dvě. P je víceméně jisté, problém nastává u druhého znaku, který je na L prohnutý špatným směrem, doprava, což se u tohoto písmene nikde nevyskytuje. Další možnosti jsou E nebo I, ale ani jedno se nezdá vhodné, zvláště pro neobvyklou délku. Dalším znakem je I, následuje V/U a S. Proto považuji za pravděpodobné, že se zde setkáváme se slovem PIUS. Druhá část by znamenala jméno. Je více možností čtení. Cuntzovo $B^{221}$ může být $A, B$ nebo R. Také je zde možnost, že s následujícím znakem tvoří M. Konec slova je opět jasný: ICIUS. Podle mého názoru je velmi pravděpodobné jméno BRICIUS, latinizované keltské mužské jméno. ${ }^{222}$ To by znamenalo, že proklínaných není osm, ale devět. Čtení třetího řádku by tedy bylo: SERVI ATQUE PIUS BRICIUS.

221 Cuntz 1913, 207.

222 Např. biskup Bricius z Tours (ca 370-444) ; Delamarre 2004, 234. 


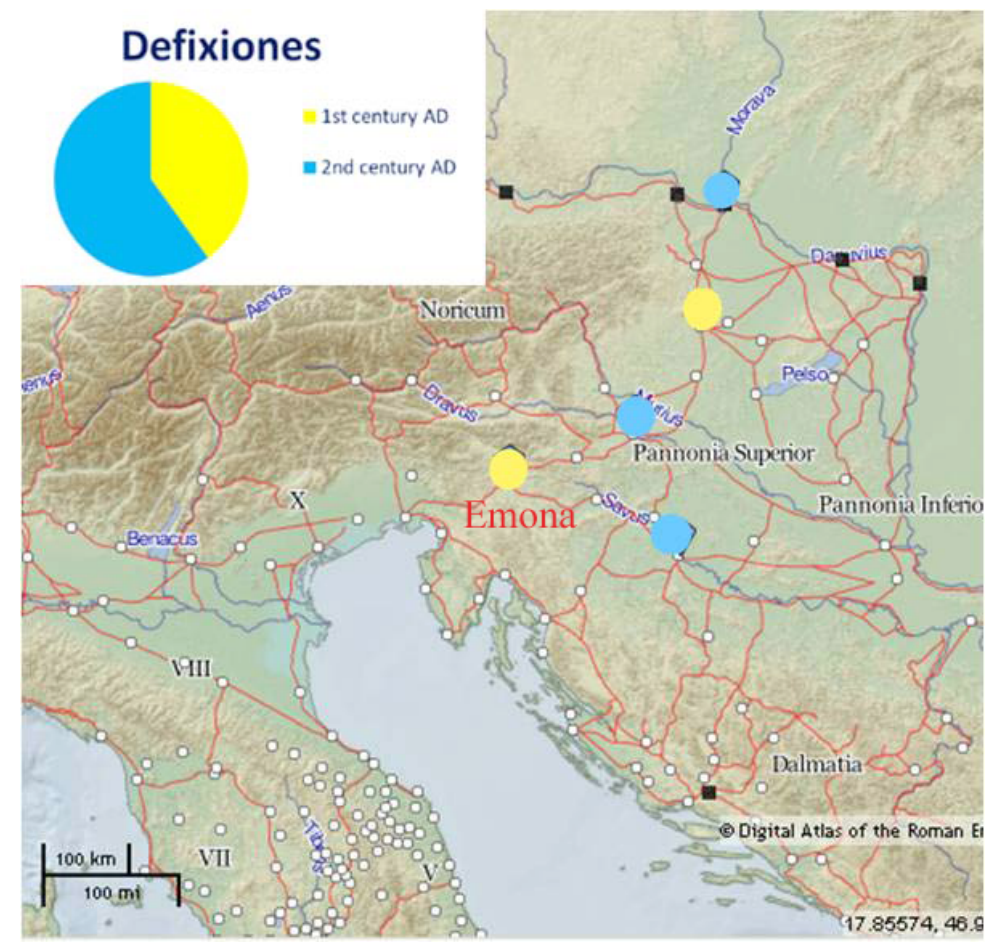

Mapa 1. Pannonie

\section{Príspěvek k diskuzi: kam patří Emona?}

Když jsem se poprvé dostala k této destičce, narazila jsem na malý problém. Ve většině epigrafických a lingvistických knih se uvádí destička z Emony mezi pannonskými. Ale při hledání na internetu jsem zjistila, že ostatními bývá Emona řazena do italského Regia X. Proto jsem se rozhodla udělat malou studii na toto téma s přihlédnutím k destičce.

Podle Šašel Kos Emona nikdy nepatřila do Pannonie administrativně, naopak byla roku 41 před naším letopočtem inkorporována do Itálie s Gálií Cisalpinou. ${ }^{223}$ Hlavním dokladem této teorie je hraniční kámen z Bevke, který byl objeven roku 2001 v korytě řeky Ljubljanice.

223 Šašel Kos 2012, 80. 


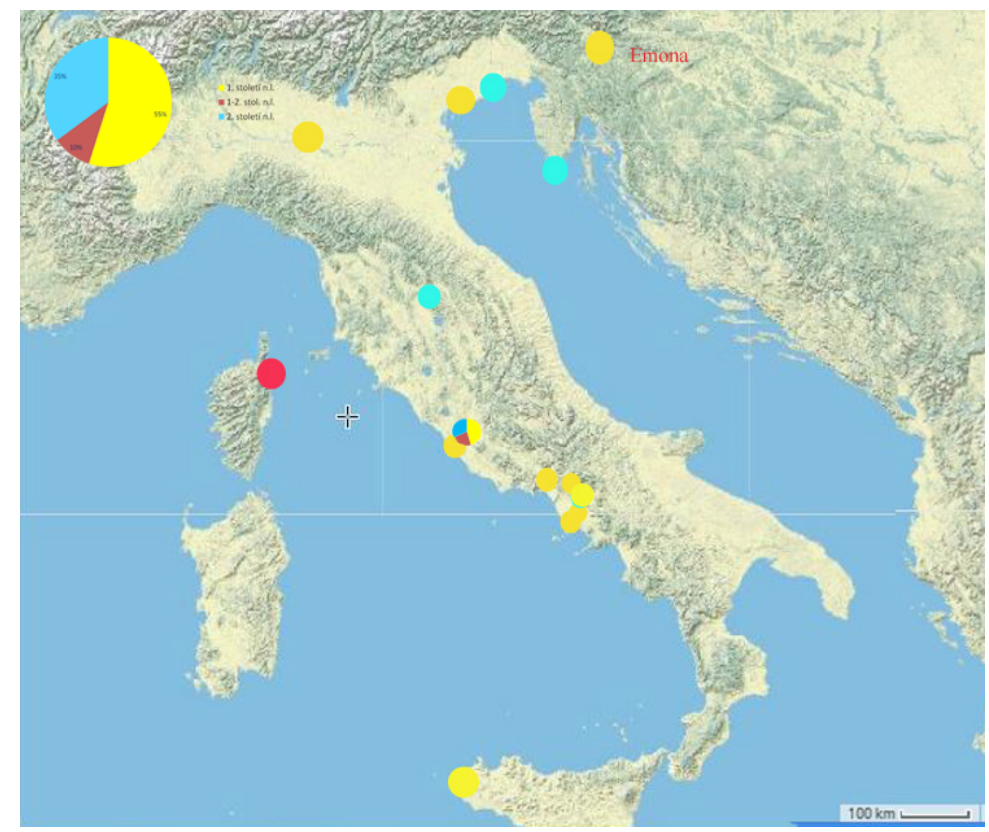

Mapa 2. Itálie

Nese tři nápisy, první je napsán z vrchu: FINIS. Na obou stranách jsou pak další dva nápisy: AQUILEIEN/SIUM a EMONEM/SIUM. Podle mého názoru se jedná o velmi důležitý argument, jelikož zde není uveden název jiné provincie, proto obě města patři do jedné administrativní jednotky. 224

Na druhou stranu pak máme dva velice významné historické zdroje: Claudia Ptolemaia a Plinia, oba zmiňuji Emonu dvakrát. Avšak z jejich popisu se zdá, že spišse je Emona do Pannonie prikikádána z hlediska geografického, než administrativního. ${ }^{225}$

Nyní bych ráda přednesla pár myšlenek zohledňující defixio. Za prvé, pokud by opravdu byla destička z Emony pannonská, jednalo by se 0 nejstarší využití této praktiky $v$ této provincii, v Itálii by byla již

224 Šašel Kos 2002, 374-378.

225 Šašel Kos 2012, 83. 
jedenáctou. Pro lepší představu se můžete podívat na statistiku a její zobrazení na mapě (Pannonie: mapa 1; Itálie: mapa 2). Uvedeny jsou pouze první dvě století.

Druhou destičkou z prvního století v Pannonii je ze Savarii, kultovního centra. Datována je do flávijského období. Je jisté, že byla inspirována Itálií a orientálními kulty, už jen faktem, že byla objevena v Iseu. ${ }^{226}$ Zbylé čtyři destičky pocházejí z druhého století.

\begin{tabular}{|c|c|c|}
\hline Datace (AD) & Pannonie & Itálie \\
\hline 1. století & 2 & 10 \\
\hline 1.-2. století & - & 2 \\
\hline 2. století & 4 & 7 \\
\hline
\end{tabular}

Za druhé, je velice zvláštní umístění destičky v domě. Teoreticky je možno spojit její prítomnost $s$ odvodovým kanálem v místnostech 52 a 56, ale ani to není zvykem, aby byl použit kanál u vstupu do domu. Další možností je spojení s majitelem domu, jak tomu zřejmě je u řecké IL 997 ze čtvrtého století před naším letopočtem, nalezené v rámci industriální zóny athénské Agory. Podle Younga bylo zamýšleno ubližiti kováři, který v tomto konkrétním domě pracoval. ${ }^{227}$ Na druhou stranu pak můžeme spojovat tento dům spíše s božstvem než majitelem, $v$ tomto prípadě se jedná o Mater Magna Oreia. Posledním faktem je, že destička je psána kurzívou. Všechny ostatní pannonské destičky jsou psány kapitálkami. V Itálii je $\vee$ prvních dvou stoletích kurzíva již běžně užívána, např. na proklínací destičce z Altina. ${ }^{228}$ Podle mého názoru je velmi důležité zohlednit tento fakt v pro-italské teorii. Kurzíva byla součástí tradiční rímské školní výuky. Pokud se jedná o provincie, zde potkávám kurzívu od druhé poloviny prvního, ale daleko spíše ve druhém století. ${ }^{229}$

226 Barta 2012,167.

227 Young 1951,223.

228 Destička z Altina je datována do prvního století.

${ }^{229}$ U destiček z Mogintiaca psaných kurzívou nemáme konkrétní dataci, proto jsou všechny zde nalezené destičky datovány obecně od založení chrámu. 


\section{Závěr}

Proklínací destička z Emony je velice zajímavým objektem zkoumání, je ovšem velice důležité uvažovat o takovýchto artefaktech nejen jako o epigrafických, ale i archeologických zdrojích poznání. Zdá se mi, že mnoho profesionálů na toto zapomíná a zaměřuji se výhradně jen na jednu část. Ale obvykle datujeme podle kontextu, jelikož je to spolehlivější než analýza písma. Bohužel Dủm VI, kde byla destička objevena, byl zkoumán před vice než sto lety, tudíz je jen velice obtižné mluvit o archeologickém kontextu. Na druhou stranu nám to dává prostor pro vlastní inovaci.

Ráda bych propojila tuto konkrétní destičku s kultem Mater Magna, jelikož její oltáŕ byl nalezen ve stejném domě, ačkoli je datován o století později. Kontinuita kultovního místa je přeci velmi dobře známý fakt

Raději bych potvrdila Cuntzovu dataci do raného císařství, než pozdější teorie o druhé polovině století. Fakt, že ležela v nespodnější vrstvě pokojů, jejichž stavba započala v augustovském období, a že spolu s ní v těchto místnostech byly nalezeny i další artefakty ze stejného období, je podle mého dobrým dokladem.

Velmi důležitá je i má nová typologie písmen (znaků) a zaměření se na třetí řádek, kdy jsem navrhla nové čtení. Jméno, které jsem navrhla je keltského původu, stejně jako jediné ženské jméno na seznamu.

V Itálii bylo doposud objeveno na 72 destiček a já doufám, že jsem dokázala, že tu emonskou je nutné počítat jako 73., podle datace, místa uložení a druhu užitého písma. 


\section{Literatura}

Audollent, Auguste 1904: Defixionum Tabellae, Paris.

Barta, Andrea 2012: „Milites Magistratusque: A New Curse Tablet from Savaria", in: Acta Classica Universitatis Scientiarum Debreceniensis 48, 167-173.

Blänsdorf, Jürgen 2012: Forschung zur Lotharpassage. I, Die Defixionum tabellae des Mainzer Isis- und Mater Magna-Heiligtums: Defixionum tabellae Mogontiacensis (DTM), Mainz.

Betz, Hans Dieter ed. 1986: The Greek Magical Papyri in Translation Including the Demotic Spell, Chicago - London.

Cuntz, Otto 1913: „Römische Inschriften aus Emona“, in: Jahrbuch für Altertumskunde 7, 193-217.

Delamarre, Xavier 2004: „Index de J. Whatmough, the Dialects of Ancient Gaul”, in: Veleia 21, 221-287.

Eidinow, Esther 2007: Oracles, Curses, and Risk Among the Ancient Greeks, Oxford.

Gager, John G. 1999: Curse Tablets and Binding Spells from the Ancient World, Oxford - New York.

Gordon, Richard L. 2013: „Gods, Guilt and Suffering: Psychological Aspects of Cursing in the North-Western Provinces of the Roman Empire", in: Acta Classica Universitatis Scientiarum Debreceniensis 49, 255-281.

Hoffiler, Victor - Savaria, Balduin 1938: Antike Inschriften aus Jugoslavien, Zagreb.

Chalupa, Aleš 2011: „Velká Matka a Attis na proklínacích tabulkách: Role orientálních božstev v antické magii a náboženství", in: Religio 19/2, 237-252.

Jordan, David R. 1985: „Defixiones from a well near the Southwest Corner of the Athenian Agora", in: Hesperia 54, 198-252.

Kropp, Amina 2008: Defixiones. Ein aktuelles Corpus lateinischer, Speyer. 
Marcos, Juan-José 2014: Paleographic fonts for Latin script, Plasencia.

Petropoulos, John C. 2008: „Magic in Ancient Greece“, in: Petropoulos, John C. (ed.), Greek Magic Ancient, Medieval and Modern, London - New York, 3-5.

Selem, Petar 1980: Les Religions Orientales dans la Pannonie Romaine: Partie en Yougoslavie [Education and Society in the Middle Ages and Renaissance Études préliminaires aux religions orientales dans I'Empire romain 85], Leiden.

Schmid, Walter 1913: „Emona“, in: Jahrbuch für Altertumskunde 7 , 61-188.

Šašel Kos, Marjeta 2002: „The Boundary Stone between Aquileia and Emona", in: Arheološki vestnik 53, 373-382.

Šašel Kos, Marjeta 2003: „Emona Was in Italy, not in Pannonia”, in: Šašel Kos, Marjeta - Scherrer, Peter (eds.), The Autonomous Towns of Noricum and Pannonia/ Die autonomen Städte in Noricum und Pannonien [Situla 41], Ljubljana, 11-19.

Šašel Kos, Marjeta 2008: „Divinities, priests and dedicators at Emona“, in: Caldelli, Maria Letizia, Gregori - Gian Luca - Orlandi, Silvia (eds.), Epigrafia 2006, Atti della XIVe Rencontre sur l'épigraphie in Onore di Silvio Panciera [Tituli 9], Rome, 687-710.

Šašel Kos, Marjeta 2010: „Adsalluta and Magna Mater - Is there a link?", in: Arenas-Esteban, J. A. (ed.), Celtic religion across space and time [IX Workshop F.E.R.C.A.N.], Castilla-La Mancha, 242-256.

Šašel Kos, Marjeta 2012: „Colonia lulia Emona - the Genesis of the Roman City", in: Arheološki vestnik 63, 79-104.

Tomlin, Roger S.0. 1988: Tabellae Sulis: Roman Inscribed Tablets of Tin and Lead from the Sacred Spring at Bath, Oxford.

Urbanová, Daniela 2014: Latinské proklínací tabulky na území Rímského imperia, Brno.

Young, Rodney S. 1951: „An Industrial District of Ancient Athens”, in: Hesperia 20, 135-288.

Županek, Bernarda 2010: Emona, Myth and Reality, Ljubljana. 


\section{Databáze}

Epigraphische Datenbank Heidelberg (EDH) [online database]. Heidelberger Akademie der Wissenschaften (HAW), 1986 - . Dostupné z: <http://edh-www.adw.uni-heidelberg.de/inschrift/suche> (25.02.2015)

\section{Seznam zkratek}

AlJ Hoffiller, V. - Savaria, B. 1938: Antike Inschriften aus Jugoslavien. Zagreb.

CIL Corpus inscriptionum latinarum.

dfx. Kropp, A. 2008: Defixiones. Ein aktuelles Corpus lateinischer. Speyer.

DT Audollent, A. 1904: Defixionum Tabellae. Paris.

DTM Blänsdorf, J. 2012: Forschung zur Lotharpassage. I, Die Defixionum tabellae des Mainzer Isis- und Mater MagnaHeiligtums: Defixionum tabellae Mogontiacensis (DTM). Mainz.

GMP Betz, H. D. 1986: The Greek Magical Papyri in Translation Including the Demotic Spell. Chicago - London.

IL Iron and Lead- Inventory number by the Athenian Agora Excavations (American School).

ILJug Šašel J. et Šašel I. 1963-1986: Inscriptiones Latinae quae in lugoslavia inter Annos ... et ... Repertae et Editae Sunt. Ljubljana.

PGM Papyri Graecae Magicae.

RINMS Šašel Kos, M. 1997: The Roman Inscriptiones in the National Museum of Slovenia. Ljubljana.

TS Tomlin, R.S.0. 1988: Tabellae Sulis: Roman inscribed tablets of tin and lead from the sacred spring at Bath. Oxford. 
2. KAPITOLA

POLITIKA A DĚJINY 


\section{Michal Habaj}

\section{Správní reformy Kambýsa II. v období 530-525 před n. I.}

\section{Úvod}

Kambýses II. dostal ve starověkých narativních pramenech prostor především díky své výpravě do Egypta v roce 525 před n. I. Na trůn však nastoupil už v roce 530 před n. I. Těchto necelých pět let, které uplynuly mezi jeho nástupem na trůn a výpravou do Egypta dodnes představují jistým způsobem záhadu. Z pramenů jasně nevyplývá, zda reformoval zděděný stát nebo jen navazoval na politiku svého otce. $V$ podstatě jedinou skutečností, kterou můžeme o Kambýsovi v tomto období ríci s jistotou, je, že se musel věnovat rozsáhlým vojenským př́pravám. Vycházíme z faktu, že velké perské vojenské výpravy vyžadovaly dlouhý čas. Víme, že Dáreiovým tažením do Řecka předcházely několikaleté přípravy: po neúspěchu prvního z tažení, vedeného Mardoniem v roce 492 před n. I., trvalo rok, než proběhla potřebná obnova lod'stva, vojska a diplomatická príprava nového tažení; po Marathónu trvaly perské přípravy tři roky a přesto se výprava neuskutečnila, protože vypuklo povstání v Egyptě. ${ }^{230}$ Xerxovi, synovi Dáreia, trvaly prípravy na tažení mimo perské území dokonce čtyři roky. ${ }^{231}$ Dodejme, že z perských

${ }^{230}$ Vycházíme z Hérodotovy zprávy (7.1), že Dáreios připravoval výpravu proti Řekům hned po neúspěchu při Marathónu. Ve zprávě však zaznívá Hérodotův řekocentrismus, v rámci kterého popisuje válku proti Řekům jako hlavní cíl perské politiky. Jsme velmi málo informovaní o ostatních částech říše, abychom mohli posoudit, nakolik toto Hérodotovo tvrzení o Dáreiově zájmu o Řecko odpovídá realitě.

231 Hdt. 7.20. 
vojenských výprav zaznamenaných v pramenech se z pohledu komplexnosti a rozsáhlosti jeví Kambýsova výprava jako jeden ze tří největších vojenských projektů v dějinách Staroperské říše vůbec. ${ }^{232}$ Lod'stvo a pěši vojsko v takovém rozsahu prameny dokumentují jen při Dáreiově výpravě proti Skythům v roce 513 před n. I. a Xerxově výpravě do Řecka $v$ roce 480 před n. I. Jestliže Kambýses spustil svoji výpravu už čty̌ri roky po nástupu na trưn, zdá se pravděpodobné, že se orientoval na egyptský projekt od počátku svého vládnutí. Pro nás z uvedených faktů vyplývá základní otázka. Pohltilo vedení vojenských příprav Kambýsa natolik, že ponechal organizaci zděděného státu úplně beze změn?

Na otázku se v našem přispěvku nesoustředíme komplexně, ale zaměříme se jen na Kambýsovy možné zásahy do správy řiše. Vzhledem na skromnou pramennou bázi budeme vycházet hlavně z indicií, které nám poskytují antičtí historici, Behistunský nápis a babylonské klínopisné materiály administrativního charakteru. Při práci představuje hlavní problém určení chronologie reforem perské správy, nebot Kambýses vládl mezi dvěma vưbec nejslavnějšími staroperskými králi, mezi Kýrem II. a Dáreiem I., a jeho možné reformy tak do velké míry splývají s činy těchto dvou mužů. Prameny nám poskytují indicie, které vypovídají o organizaci správy za Čišpiovců, tedy za vlády Kýra a Kambýsa, díky čemuž můžeme ještě do značné míry odlišit čišpiovskou organizaci od Dáreiovy reorganizace řiše, ale vymezit v rámci čišpiovské organizace Kambýsovy kroky od Kýrových, představuje jen těžko řešitelný problém. Vzhledem $\mathrm{k}$ těmto problematickým okruhům shrneme nejdřive v našem príspěvku indicie, které máme o čišpiovské organizaci řiše, a následně se budeme věnovat vymezení Kambýsových potenciálních reforem od základů správní organizace, které zavedl už jeho otec Kýros II.

\section{Kořeny satrapiální správy za Čišpiovců}

Ve svém slavném a mnohokrát citovaném traktátě o Dáreiových správních reformách Hérodotos uvedl, ${ }^{233}$ že Dáreios uspořádal správní obvody, určil jim místodržitele a daňové povinnosti. Do jednotlivých

232 Habaj 2014.

233 Hdt. 3.89. 
daňových obvodů zorganizoval více národů, které za vlády Kambýsa posílaly tribut samostatně. Hérodotos ještě doplnil, že Peršané nazývají tyto správní obvody satrapie. Kořeny satrapiálního zřízení však vznikly již v časech Dáreiových předchůdců a z pramenů jasně vyplývá, že Čišpiovci svou řiši neorganizovali jako volný spletenec vazalských krajin, ale kontrolovali ji prostřednictvím vytvářející se perské administrativy. Prvky satrapiálního žrízení za Čišpiovců shrneme do čtyř bodů.

(1) Čišpiovci ovládali některá podmaněná území prostřednictvím satrapů. V Behistunském nápise se sice neobjevuje ani jednou termín satrapie, ale dvakrát se v něm nachází termín satrapa, a to satrapa Baktrie a Arachosie. ${ }^{234}$ Kromě toho je v textu připomínaný i Dáreiův otec Hystapés, jako správce v Parthii. Není sice označený jako satrapa, což žejmě souvisí s faktem, že se jednalo o Dáreiova otce, ${ }^{235}$ ale charakter jeho činností odpovídá činnosti baktrijského a arachoského satrapy. Kromě satrapů z Behistunského nápisu známe ještě z babylonských dokumentů a Hérodových Dějin tři správce provincií: Góbrya, Oroita a Mitrobata. ${ }^{236}$

V krátkosti nyní načrtneme povinnosti a funkce prvních satrapů. V překladě toto označení znamená „ochránci království“ nebo „ochránci provincie". Právě od označení tohoto provinčního správce odvodili

234 Behistunský nápis=DB §38; §45.

235 Namísto tradičního označení, jakým jsou v textu uvedení Dadaršiš a Vivana „můj poddaný, satrapa krajiny $X Y^{\prime \prime}$ je celkem logicky v nápise uvedený jako „můj otec”. Hérodotos (3.70) ho označil jako hyparcha, ale ne Parthie, ale Pársy, což se v zásadě nevylučuje, nebot' oba prameny připomínají Hystaspa v jiném období.

${ }^{236}$ Góbryas/Gubaru vystupoval v babylonských tabulkách s titulem bēl pihāti (Kuhrt 1988, 125). Oroita Hérodotos označoval jako hyparcha a Mitrobata nazýval archontem (3.120) a též hyparchem (3.126). T. Petit sice Mitrobata jako satrapu zamítnul (1990, 41-42), nebot' archeologické výzkumy z jeho pohledu nepotvrdily, že by Daskyleion velikostí, lidnatostí či významem představovalo centrum satrapie (181), sám si však uvědomoval, že písemně satrapii v pátém století dosvědčil i Thúkýdidés (8.6; 8.9). Ktésias F9(8) ješte připomíná dva satrapy, a to Spitaka jako satrapu Derbiků a Megaberna jako satrapu Barkanů. V Ktésiově podání je Kýros postavil do funkce na smrtelné posteli. 0 jejich osudech se více nedozvídáme a relevantnost této informace je sporná, nebot' odpovídá vysloveně Ktésiově verzi o poslední Kýrově výpravě proti Derbikům. 
řečtí autoři označení „satrapie” pro provincii spravovanou satrapou. Ve staroperských pramenech se přitom termín „satrapie“ neobjevuje vưbec, setkáváme se v nich výhradně se satrapou, takže s termínem navázaným na osobu a ne na území. ${ }^{237}$ Satrapové z Behistunského nápisu spojují dva jmenovatele. Prvním je jejich etnický původ. Všechny tři text představuje jako Peršany spravující rozsáhlou provincii. Druhým společným jmenovatelem je jejich zodpovědnost za jimi spravované území. Zatímco do jiných vzbourených krajin Dáreios vyslal různé vojenské velitele, problémy v Baktrii, v Arachosii a v Parthii v textu Behistunského nápisu řeší místní satrapové. Z pramenů také vyplývá, že již čišpiovští satrapové disponovali značnou autonomií prezentovanou vlastním vojskem. Baktrijský, arachoský i parthský satrapa porazili podle svědectví zachovaného na Behistunském nápise povstalce se svými vojsky rekrutovanými ze spravovaných provincií. Širokou autonomii vidíme i ve spravování Oroita, správce lónie a Lýdie. Podle Hérodota přerostla po Kambýsově smrti jeho správa v západní Malé Asii dokonce do samovlády. ${ }^{238}$ Do práce satrapy vidíme poměrně detailně také díky babylonským chrámovým archivưm. Góbryás, babylonský satrapa, přerozděloval půdu, staral se o dodávky pracovních sil na státních projektech, o zásoby pro královský dvưr, působil jako soudce a dostával zprávy o mrtvých a uprchlých chrámových otrocích. ${ }^{239}$ I další satrapové žrejmě řešili podobné záležitosti.

(2) Čišpiovci spojili historické kraje do větších správních celků. Jedná se sice jen o hypotézu, ale počátky vývoje širší správní administrativy můžeme teoreticky vidět opět v Behistunském nápise ve třech případech. První př́iklad poskytuje povstání v Sagartii. ${ }^{240}$ Dáreios proti němu vyslal perské a médské vojsko pod velením Méda Tachmaspadu. Ten povstání potlačil a písaři Behistunského nápisu uzavřeli celou událost konstatováním, že se odehrála v Médii. Sagartie podle toho v nějakém smyslu zapadala do médské správy. Druhým př́kladem je př́pad Parthie a Hyrkánie. Obě dvě krajiny povstaly, ale v textu jsou

237 Pro vývoj pojmu satrapa/satrapie a jeho významu srv. Klinkott 2005, 28-30.

238 Hdt. 3.126.

239 Dandamaev 2006, 376-377.

240 DB $\S 33-34$. 
uvedeni jen Parthové, zatímco o Hyrkánech v něm není ani zmínka. ${ }^{241}$ Vysvětlením by mohlo být právě začlenění Hyrkánie do většího správního celku s centrem v Parthii. Trétí př́klad spojení rozličných celků se v textu objevuje při povstání v Margiáně. ${ }^{242}$ To potlačil baktrijský satrapa Dadaršiš, z čehož by mohlo vyplývat, že Margiána patřila do širšího celku spravovaného právě z Baktry. ${ }^{243}$ Začlenění Sagartie, Hyrkánie a Margiány do větších celků je zřetelné i z jejich absence v seznamech ovládaných krajin, vyhotovených Dáreiem a Xerxem. ${ }^{244}$

$241 \mathrm{DB} \S 35-36$.

242 DB §37-38. Tento argument vychází ze staroperské verze textu nápisu, kde úsek věnovaný událostem v Margiáně uzavírá konstatováním, že dané události se odehrály v Baktrii. V akkadské verzi se však uvádí, že události se odehrály v Margiáně a v Baktrii a v aramejské verzi jsou dokonce události lokalizované do Margiány. Označení krajin v textu nápisu tak nemusí prozrazovat správné rozdělení říše, ale může vycházet ze zažitých označení. Vogelsang by například přidělil z geografického pohledu Margiánu k Parthii a ne k Baktrii (1992, 127). V naší argumentaci dáváme přednost staroperské verzi, nebot' na rozdíl od jiných použitých jazyků mohl být její tvưrce citlivější v geografické terminologii, když nápis z perského pohledu nesl i politické poselství.

${ }^{243}$ Platí to však jen za podmínky, že Margiána nebyla součástí Baktrie už před začleněním do Staroperské říše. Margijští povstalci si zvolili v Behistunském nápise velitele a nevedl je král legitimizující se svým královským původem (DB §38), takže v Margiáně žrejmě chyběla monarchická tradice, ale na druhou stranu ani v Baktrii nemáme důkazy o rozvinutí státu před začleněním do Staroperské říše. Margiánu a Baktrii spojil podobný kulturní vývoj (Lyonnet 1986, 82, 86) a archeologické nálezy dokumentující urbanizační vývoj nejprve poukazují na to, že Baktrie podobně jako Margiána ještě jen stála před rozvinutím státního žrizení. (Dandamaev 1994, 43). Podobně i Diakonoff tvrdil $(1961,75)$, že organizované stání útvary se ve Střední Asii rozvinuly až po jejím připojení do Perské říše. Na rozdíl od toho Masson $(1959,135)$ na základě vývoje zavlažovacího systému a pevností předpokládal vznik státu v Margiáně už před začleněním do Staroperské řiše a v prípadě Baktrie dokonce hovořil o Baktrijské říši. Možný kulturní a hospodářský rozkvět Baktrie ještě před obdobím perské nadvlády naznačil i Vogelsang (1992, 273-4). Upozornil na to, že už v první polovině prvního tisíciletí se sídliště v Kyzyl-tepe rozkládalo na 30 hektarech a samotná Baktrie zabírala okolo 120 hektarů. Přítomnost rozsáhlých sídlišt', pevností a zavlažovacího systému bezpochyby jsou předpoklady vzniku existence státu, ale v Baktrii ho ještě definitivně nedokazují, srv. Briant 1984. Větší správní jednotku, žejmě s centrem v Baktře, naznačil i Ktésias F9(8); F13(12). Margiánu v daném kontextu však nepřipomíná. V naší argumentaci vycházíme z perské verze Behistunského nápisu a na jejím základě se Margiána zdá být součástí větší satrapie s centrem v Baktře.

244 DB §4; XPf (Xerxův královský nápis z Persepole). 
(3) Za Čišpiovců se objevili satrapiální úredníci. Královským správcům asistovali, alespoň v prípadě Oroita či Góbrya, královští písaři či královští pokladníci. ${ }^{245}$ Ustanovení královských písarư či pokladníků zřejmě probíhalo hlavně v oblastech, kde ještě neexistoval centrální způsob vlády, administrativní tradice a zavedená písařská kultura. Kýros či Kambýses mohli v krajinách s písarskou tradicí sáhnout po lokálních lidech, znalých místního prostředí. Príklad poskytují Kýrovy reformy v Lýdii, kde perský vládce určil za správce Sard Peršana Tabala, ale pokladnici svěril Lýdovi Paktyovi. ${ }^{246}$

(4) Vývoj státní písařské administrativy začal za Čišpiovců. Dáreios I. kontroloval řiši prostřednictvím písařské agendy, když písaři zaznamenávali pohyb osob, príijem, a nebo výdej dávek. Písařská administrativa však nefungovala ve všech krajinách. V Babylóně Peršané mohli navázat na chrámovou administrativu, ale napríklad v Párse byli nuceni rozvinout rozsáhlý státní aparát, jehož fungování a existenci odrážejí v období Dáreia persepolské fortifikační tabulky. Klínopisný dokument YOS 7,187 naznačuje, že tento státní písařský aparát vznikal už v časech Dáreiových predchůdců. Z dokumentu se dozvídáme, že do města Matnanu, které můžeme identifikovat jako město Matanna, ležící na severozápad od Persepole, ${ }^{247}$ povolal někdo z Kambýsových lidí 40 babylonských pracovníků navázaných na chrám Eanna v Uruku. Měli pracovat na polích či zahradách v jeho paláci. Po príchodu do Pársy jim byly zabezpečeny dávky a dá se předpokládat, že o nich zůstal záznam

\footnotetext{
${ }^{245}$ Královský písař je doložený na Oroitově dvoře u Hérodota (3.128) a královský pokladník v Babyloně např. ve Starém zákoně (Ezd. 1.8).

246 Hdt. 1.153. Paktyova úloha u Hérodota jako i v Plútarchově spise 0 Hérodotově zlomyslnosti 20 se dá vyložit dvojím způsobem. Podle jedné verze se sice mohl stát správcem pokladnice, ale podle druhé dostal za úlohu její transport do Babylónu. Srv. Briant 2002, 882. Přikláníme se k jeho úloze správce pokladnice, nebo pokud by bylo třeba poklad převézt, tak se zdá pravděpodobnější, že by danou úlohu Peršané svěrili Íránci, který by měl vojenské kompetence a znal by dưvěrněji zázemí vznikající říše jako Lýd. Paktyova úloha se tak jeví logičtější v lokálním kontextu a z Hérodotova textu též nevyznívá, že by se připravoval na odchod. V takovém smyslu chápal Paktyovu úlohu i Balcer 1995, 62.

247 Pro identifikaci a polohu města (či vesnice) srv. Henkelman - Kleber 2007, 166-167.
} 
podobný pozdějším persepolským archivním záznamům. ${ }^{248}$ Počátky státní administrativy, známé z persepolských fortifikačních tabulek, tak mohou sahat ke Kambýsovi, resp. k Čišpiovcům.

\section{Kýros nebo Kambýses?}

Na předcházejících řádcích jsme shrnuli fakta a indicie, které nám dávají jistou představu o vytváření satrapiální správy před obdobím vlády Dáreia I. Nyní nás čeká náročnější úloha zauvažovat nad tím, které z uvedených kroků můžeme prípočítat Kambýsovi. Postupovat budeme podle výše naznačených bodů.

(1) Satrapové se objevili už za Kýra, to je jedna z mála jistot, kterou při výzkumu satrapiální správy máme. Prostřednictvím záznamů babylonské chrámové administrativy jsme informováni, že Kýros ustanovil v roce 535 před n. I. za správce Babylónie a území za Eufratem, tedy nesmírně rozsáhlého území shodného príbližně s Novobabylonskou řřší, Góbrya, který vydržel ve své funkci celé období Kambýsovy vlády. ${ }^{249} \mathrm{Od}$ Hérodota zase víme, že i Oroites, který spravoval ze Sard Lýdii a lónii, byl do své pozice jmenován za Kýrovy vlády. ${ }^{250}$ Kdy se stal Mitrobatés správcem v Daskyleiu, jasné není. ${ }^{251}$ Podobně nevíme, kdy nastoupili do svých funkcí satrapové z Behistunského nápisu. Mohli nastoupit za Kambýsa, ale faktem zůstává, že Kambýses ve využivání satrapů ve správě ríše jen navázal na politiku svého otce.

(2) Při spojování historických regionů do větších správních celků je jistot v porovnání s předcházejícím bodem méně. Nemůžeme vyloučit, že některé historické krajiny mohly být součástí větších celků už před začleněním do perského soustátí, mohl je tam začlenit také Kýros, ale je možné, že některé z nich prevedl pod správu větších celků právě

248 Henkelman - Kleber 2007, 170. Tento předpoklad je pravděpodobný, nebot když vznikl administrativní dokument v Uruku, odkud byli pracovníci vysláni, musela o nich existovat i dokumentace při príjezdu, nebo z Uruku odešli na základě rozhodnutí z Pársy.

249 Kuhrt 1988, 128.

250 Hdt. 3.120-127.

251 Hdt. 3.120. 
Kambýses. Jedna Xenofóntova zpráva např́ilad naznačuje, že Hyrkánci nepatřili po dobu Kýrova života do žádného většího správního celku. ${ }^{252} \mathrm{Na}$ druhou stranu víme, že to byl právě Kýros a ne Kambýses, kdo strávil podstatnou část své vlády na východě říše, a celkem logicky tak vyznívá předpoklad, že při pacifikování Střední Asie a východních provincií spojil některé oblasti do větších správních celků, aby ulehčil jejich organizaci. Naznačovaly by to i zprávy z Xenofóntovy Cyropaedie a Ktésiovy Persiky, které popisují, jak Kýros na smrtelné posteli svěril pod správu mladšího syna Bardiji čtyři historické kraje, které v daném kontextu představují jednu velkou satrapii. ${ }^{253}$

(3) 0 úřednících satrapiální administrativy víme bezpečně už z Kýrových časů. Navíc z pramenů vyplývá, že Kýros posiloval kontrolu v jednotlivých regionech instalací vojenských posádek. Z období vlády zakladatele řiše víme napríklad o posádce ve Fókaii, ${ }^{254}$ či o pevnosti Kýrúpolis, založené na severovýchodních hranicích řiše ${ }^{255}$ Kambýses tyto posádky udržoval a je možné, že sám zř́dil další. Z textu Behistunského nápisu se dozvídáme o dvou posádkách v Arménii dislokovaných v pevnostech Tigra a Ujama, ${ }^{256}$ o pevnosti v Ekbataně ${ }^{257}$ či pevnosti Sikajauvatiš v Médii. ${ }^{258}$ Text nápisu pripomíná ještě dvě pevnosti v Arachosii. ${ }^{259}$ Navíc postupné rozšiǐování pevností a posádek dokumentuje jejich široké rozšřr̃ení na konci šestého století, přičemž tento trend pokračoval a desítky posádek jsou doložené i z dalších období. ${ }^{260}$ Podle Xenofónta se tyto posádky zodpovídaly prímo královi a nezávisely na postupně se tvoříím satrapiálním systému kontroly a výběru dávek. Výlohy posádky však musel snášet region, kde byla posádka umístěná, pokud se už jednalo o satrapii, tak za ně zodpovídal satrapa. Xenofón

\footnotetext{
252 Cyr. 4.2; Xenofóntovy zprávy jsou však nejednou v Cyropaedii anachronické.

253 Xen. Cyr. 8.7; Ctes. F8(8).

254 Hdt. 1.165.

255 Arr. 4.3.

256 DB $\S \S 27,28$.

257 DB $\S 32$.

258 DB $\S 13$.

259 DB $\S \S 45,47$.

260 Pro podrobný výpočet doložených perských posádek srv. Tuplin 1987, 235-241.
} 
ještě zprávu podtrhl tvrzením, že systém takto funguje i za jeho života, navíc tuto zprávu uvedl ve dvou svých dílech, takže se zdá být relevantní. ${ }^{261}$

V Cyropaedii ještě doplnil, že Kýros zríidil tyto posádky po celé řiši, což by mohlo znamenat, že Kambýses už pri jejich instalování nemusel být aktivní. Zřizování posádek též dává smysl po ovládnutí krajiny, resp. po potlačení místního povstání. Po dobu Kambýsovy vlády nemáme do jeho egyptského tažení žádné zprávy o povstání a říši, kterou zdědil, ovládl jeho otec, takže se zdá, že Kambýses jen udržoval zrízené posádky a až Dáreios začal s instalací nových. ${ }^{262}$

(4) Zř́zení státní písařské administrativy v regionech, bez administrativní tradice. $V$ tomto bodě vidíme největší prostor pro Kambýsovu aktivitu. Kambýses se po dobu svého regentství nad Babylónií v období 539/538 před n. I. důvěrně seznámil s chrámovou administrativou a zdá se pravděpodobné, že ji zavedl na svých majetcích v Párse, čímž položil základy pozdější státní písařské administrativy známé z Dáreiových časů. Opět se v tomto bodě vynořují i protiargumenty. Kambýsův otec Kýros totiž začal výstavbu Pasargad, které se zúčastnili pracovníci z celé ŕíše, a můžeme předpokládat, že se vedla nějaká forma záznamů o jejich počtech a dávkách, které jim byly vydány. Na druhou stranu jediný dokument, výše vzpomínaný YOS 7,187, který naznačuje existenci podobných záznamů, jaké známe z období panování Dáreia I. z Persepole, pochází právě z Kambýsova období a týká se prímo královského majetku v Párse.

\section{Stručný závěr}

Výše uvedené postřehy ukončíme konstatováním, že navzdory malé pramenné základně si jistý obrázek o Kambýsových úpravách správního aparátu udělat můžeme. Zjevně kontinuálně pokračoval ve správní

2610 posádkách, jejich rozšîrení za Kýra a nezávislosti na satrapiální moci srv. Cyropaedia (8.6); o nákladech na posádky srv. Oikonomikos (4.3). K analýze Xenofóntovy výpovědi a její historické relevantnosti srov. Tuplin 1987, 167-234.

262 Vícero pevností z období Dáreiovy vlády, nacházejících se v Párse, zůstalo zaznamenáno na persepolských tabulkách, např. PT 3; PF 1812, 1972, 1973, 1974, 1975 atd. 
politice svého otce bez radikálnějších zásahů. Král spravoval své země prostřednictvím osobně vybraných lidí. V některých oblastech, at' už strategických, nestálých nebo z jiného důvodu citlivých, Kambýses ustanovil své správce - satrapy, poprípadě využil těch, které už do funkce dosadil jeho otec. Podobně jako jeho otec některé menší celky slučoval (anebo jestliže tak učinil již Kýros, tak je zanechal sloučené jako např. lónii a Lýdii), nebo je podřizoval pod větší celky (např. Sagartii k Médii) a vytvářel tak, žrejmě kvůli zjednodušení kontroly nad výběrem tributu, administrativní celky, které se plně přetavily do Dáreiových správních a daňových reforem. Nejrozsáhlejší Kambýsovou reformou mohlo být postupné zavádění písařské administrativy i v regionech, kde neměla tradici. Faktem však zůstává, že je jen těžké si představit, že by Kýros, který sám začal s vytvářením satrapií, tuto oblast správy opomenul. Proto se zdá, že ve správě Kambýses jen navazoval na svého otce a satrapiální organizaci zanechal bez výraznějších změn, protože, jak jsme zmiňovali v úvodu, jeho většinovou pozornost si vyžádaly vojenské přípravy. Zároveň mǔžeme na základě našeho shrnutí indicií konstatovat, že sice při vyhodnocení indicií zůstává jen malý prostor na úvahy o Kambýsových správních reformách, definitivně se při našem stavu poznání vyloučit nedají. 


\section{Literatura}

Balcer, Martin 1995: The Persian conquest of the Greeks 545 - 450 BC, Konstanz.

Briant, Pierre 1984: L'Asie centrale et les royaumes proche-orientaux du premiere millénaire, Paris.

Briant, Pierre 2002: From Cyrus to Alexander, Winona Lake.

Dandamaev, Muhammad 1994: „Media and Achaemenid Iran”, in: János Harmatta (ed.), History of Civilisations of Central Asia, Paris, vol. II, 35-67.

Dandamaev, Muhammad 2006: "Neo-Babylonian and Achaemenid State Administration in

Mesopotamia", in: Oded Lipschits - Manfred Oeming, Judah and the Judeans in the Persian Period, Winona Lake, 373-399.

Dyakonov, Igor 1961: Ocherk istorii drevnego Irana, Moskva.

Habaj, Michal 2015: „Prípravy perzského taženia do Egypta v roku 525 pred n. I.", in: Vojenská história 19, 6-24.

Henkelman, Wouter - Kleber, Kristin 2007: „Babylonian workers in the Persian heartland: palace building at Matannan in the Reign of Cambyses", in: Christopher Tuplin (ed.), Political and Cultural Interaction with(in) the Achaemenid Empire. Swamsea, 163-177.

Klinkott, Hilmar 2005: Der Satrap. Ein achaimädischer Amtsträger und seine Handlungsspie/räume. Frankfurt am Mein.

Kuhrt, Amélie 1988: „Babylonia from Cyrus to Xerxes”, in: John Boardman (ed.), The Cambridge Ancient History, Cambridge, vol. IV, 112-139.

Lyonnet, Bertille 1986: „Les report entre I'Asie Centrale et l'Empire achéménide d'après les données de l'archéologie". In: Heleen Sancisi-Weerdenburg - Amélie Kuhrt (ed.), Centre and Periphery, [Achaemenid History IV], 77-92.

Masson, Vadim 1959: Drevnezemledel'cheskaya kultura Margianî, Moskva - Leningrad. 
Petit, Thierry 1990: Satrap et satrapies dans l'empire achéménide de Cyrus le Grand à Xerxès ler , Paris.

Tuplin, Christopher 1987: „Xenophon and the garissons of the Persian empire", in: Archäologische Mitteilungen aus Iran 20, 167-245.

Vogelsang, Willem 1992: The Rise and Organisation of Achaemenid Empire: The Eastern Iranian Evidence, Leiden. 


\section{Daniel Šichan}

\section{Význam Vesetu v mocenské ideologii egyptských panovníků na přelomu 17. a 18. dynastie 263}

\section{Úvod}

Staroegyptský Veset (egyptsky W3st, řecky Théby) je právem považován za archeologickou lokalitu prvořadého významu. Přitom počátky jeho existence byly na základě dostupných informací spíše skromné a srovnatelné s řadovými soudobými provinčními centry. Nejstarší prítomnost člověka v oblasti Vesetu je doložena od paleolitu, v historickém období Veset plně vstupuje do běhu dějin v Archaické době (asi 3000-2686 př. n. I.) a poté zejména v době Staré ríše (asi 2686-2125 př. n. I.), kdy na jeho území vznikají první sakrální a patrně i sekulární stavby, jsou vytvářeny místní božské kulty a trvalé osídlení. I když v době Staré říše Veset na svou dějinnou chvíli ještě pravděpodobně čekal, jeho lokální význam nelze v tomto období zcela podceňovat, jak dokládá př́tomnost personifikovaného božstva vesetského kraje na tzv. triádě panovníka 4. dynastie Menkaurea, nalezená v údolním chrámu jeho pyramidového komplexu v Gíze, která je mistrovským dílem svého druhu. ${ }^{264}$

${ }^{263}$ Tento výstup vznikl v rámci projektu „Zaniklé civilizace a kulturní vývoj současných národních společenství” podprojektu „Rétorika moci panovníků 18. dynastie v rámci jejich zahraniční politiky", řešeného na Filozofické fakultě Univerzity Karlovy v Praze z prostředků Specifického vysokoškolského výzkumu na rok 2015.

264 Vlčková 2007, 36-42. 


\section{Veset v průběhu dějin do počátku Nové rríše}

K prvnímu významnějšímu politicko-kulturnímu vystoupení Vesetu došlo během tzv. První přechodné doby (asi 2160-2055 př. n. I.), která je podle pramenů mimo jiné charakterizována oslabením centrální panovnické moci a nárůstem moci a vlivu lokálních elit, které mezi sebou vedly otevřeně tvrdé boje o získání moci a kontroly oblasti kolem jejich mocenských center. Jedním z těchto center, které se během této neklidné doby transformovalo $v$ dủležitý regionální a nakonec i unifikační bod celého Egypta, byl právě zmíněný Veset. ${ }^{265}$

Důvody k tomu, že se Veset ze spiše obyčejného provinčního sídliště povznesl na "hlavní město" na konci První přechodné doby a na počátku Střední ríše (asi 2055-1650 př. n. I.), tzn. ve druhé polovině 11. a na počátku 12. dynastie, mǔžeme spatřovat především v jeho zeměpisné poloze, jejiž přednosti byly nepochybně prověřeny jeho obyvateli poprvé (a jak uvidíme, ne naposledy) právě během válečných střetů během První přechodné doby. Dostatečné logistické zázemí Vesetu, bezpečná vzdálenost od neprítele a dobrá hájitelnost pravděpodobně patřily mezi ty faktory, na jejichž základě se lokální egyptská elita a z ní následně vzešlí dř̌itelé egyptského trůnu rozhodli zvolit Veset jako svou rezidenci. Bohužel doposud nebyl z této doby na území někdejšího Vesetu takový komplex objeven. Nejstarší stavbou tohoto typu na lokalitě je palác Amenhotepa III. (asi 1390-1352 př. n. I.) z 18. dynastie, odkrytý a zkoumaný v Malkatě na západním břehu Nilu. ${ }^{266}$

Změna Vesetu v sídlo lokálních a později celý Egypt ovládajících panovníků s sebou přinesla i důležité změny ve vývoji tohoto centra a jeho regionu. Z nejlépe dochovaných změn je nutné zmínit především založení panovnické nekropole na západním břehu Nilu a vytvoření (či zdůraznění) kultů některých místních božstev v místě dnešního chrámového komplexu v Karnaku, které získaly postupem času na celostátním významu. Přesto, že se panovníci 12. dynastie rozhodli vybudovat novou rezidenci kdesi poblǐ̌ dnešního Lištu na memfidské

\footnotetext{
265 Vlčková 2007, 42-46.

${ }^{266}$ Baines - Málek 1996, 84-85.
} 
nekropoli v severní části Egypta, kde se také nechávali pohřbívat, vznikla tak tradice, která jistě napomohla k následujícímu rozkvětu Vesetu a předurčila ho stát se strategickým bodem v budoucích neklidných časech.

Takové nadešly během tzv. Druhé přechodné doby (asi 1650-1550 př. n. I.), kdy byl Egypt nucen bránit se postupně vlivu obyvatel předovýchodního původu na severu v oblasti nilské delty a na jihu proti kermským Núbijcům, kteří patrně ovládali nilské údolí až po Elefantinu na 1. kataraktu. Egypt se tak na rozdíl od První přechodné doby, která byla zapř́činěna především vnitropolitickými, hospodářskými a ekologickými problémy, ocitl ve zcela bezprecedentní situaci, kterou způsobila kombinace vnitropolitických potí̌í s infiltrací početného množství cizích obyvatel do egyptské delty z oblasti Syropalestiny již v průběhu Střední ř řše. ${ }^{267}$

Převzetí moci na severu předovýchodním obyvatelstvem $v$ čele s jeho elitami (v pořečtělé formě zvaných jako „Hyksósové”), přesídlení egyptského dvora zpět na jih do Vesetu, omezení př́stupu vesetských panovníků k surovinovým zdrojům na severu a na jihu, zmenšení egyptského území a ohrožení suverénní moci egyptského panovníka a elit signifikantně ovlivnilo i vnitropolitický vývoj v Egyptě a v neposlední řadě i postavení samotného Vesetu.

\section{Veset jako pozadí mocenské ideologie na přelomu 17. a 18. dynastie}

Veset (a v logické návaznosti i jeho okolí) se pod vlivem výše zmíněných faktorů změnilo ve výjimečné místo s jedinečnou úlohou v dějinném procesu, jak bude ještě ukázáno. Pro tuto roli Vesetu během tzv. Druhé přechodné doby a na počátku Nové řriše Ize do značné míry použít terminologii z pera slavného českého historika Františka Kutnara a to konkrétně jeho definici „regionálního momentu dějin". Ačkoliv jde o termín novodobý, důležité je, že termín odráží výklad

267 Bourriauová 2003, 201-233; k politickému postavení Vesetu na přelomu Střední říše a Druhé přechodné doby viz Illin-Tomich 2014. 
dějin konkrétního regionu a jeho centra z politického, hospodářského a socio-kulturního hlediska a pokouší se zachytit, jakým způsobem region působil na dějinný vývoj zkoumaného centra a naopak jak do vývoje regionu zasahovalo toto konkrétní centrum. ${ }^{268} \mathrm{~V}$ tomto bodu autor zároveň shledává možnost analogie a potenciál v aplikaci novodobé historiografické metodologie na problematiku dějin regionu v rámci starověkého Egypta, zastoupeného zde právě zmíněným Vesetem.

Na rozdíl od Kutnarova př́kladu, pro jehož studium existuje spektrum pramenů nejrůznější povahy, kvality a kvantity, se $v$ př́padě staroegyptského Vesetu nelze pouštět do podobně detailní analýzy a to díky omezenému množství dochovaných informací. Základním problémem v tomto ohledu je očividná nevyváženost pramenného materiálu pro výše uvedené období Druhé přechodné doby. Mnohem více informací, písemných i nepísemných, máme k dispozici z Nové říše asi 1550-1069 př. n. I., během které také Veset dosáhl vůbec svého největšího rozkvětu. Navzdory chudšímu rozsahu dochovaného materiálu se však Druhá přechodná doba může pochlubit důležitými a svým způsobem z hlediska mocenské rétoriky také jedinečnými informacemi.

Jde 0 ojedinělou písemnou fixaci epitet vesetských panovníků 16. a 17. dynastie, které staví toto město do zcela jiného světla, než je tomu $v$ prípadě jiných soudobých center $v$ zemi na Nilu. $V$ této skupině nápisů, zaznamenaných na spíše fragmentárních památkách, dokládajících stavební aktivitu těchto panovníkủ jak v samotném Vesetu, tak i na okolních lokalitách, je velice často zmíněn právě Veset a to ve velice pozoruhodných souvislostech, které nejsou pro jiná mocenská centra z Egypta doložena téměř vůbec, nebo ve zcela odlišném kontextu. V této souvislosti stojí za zmínku, že se vesetští vládci mohli nechat inspirovat podobnou rétorikou silných lokálních vládců z předcházející První přechodné doby. ${ }^{269}$

Př́klad Vesetu je z pohledu zmíněného „regionálního momentu dějin" v souvislosti s vlastní mocenskou sebeprezentací vesetských

268 Kutnar 1997.

269 Franke 1990. 
panovníků Druhé přechodné doby v dějinách Egypta vskutku ojedinělý a to i přes prokázanou existenci mnohem starších kultovně-správních center. Rozdíl mezi nimi a Vesetem spočívá podle autora právě v jedinečném propojení panovnických přídomků s touto lokalitou, které bylo přirozenou výslednicí politického vývoje Egypta během Druhé přechodné doby. Doložená písemná propojení egyptských panovníků s konkrétními středisky ze starších dob svým charakterem nedosahují takové hloubky jako v př́padě vesetských panovníků Druhé přechodné doby. ${ }^{270}$ Tento vztah vyjadřuje jakési „vyznání loajality“ těchto panovníků vůči Vesetu, který se díky své geografické poloze a předchozí dějinné úloze stal skutečným opěrným bodem v neklidné epoše. Tímto získal Veset jako konkrétní geografický bod nový kvalitativní rozměr a regionální egyptští panovníci z něho vytvořili politicko-kultovní centrum jimi ovládaného území, čímž Veset získal i jakési nepsané právo na přiznání vưdčí role v pozdějším osvobozovacím boji a na uznání jeho vládců jako právoplatných legitimních nástupců mocensky významnějších panovníků z dob Staré a Střední říše. Na následujících řádcích jsou uvedeny zmíněné dochované přídomky, které vztah lokálních egyptských vládců k Vesetu dostatečně ilustrují.

Panovník Wadžchau Neferhotep III. (kolem 1630 př. n. I.?) je titulován jako "ten, který je milován Vesetem", jako „vưdce vítězného Vesetu“ a opakovaně zmiňuje Veset jako "mé město". ${ }^{271}$ Panovník Mentuhotep (datace nejistá) uvádí: "já jsem panovník ve Vesetu, toto je mé město"272 a panovník Džedneferre Dedumose II. (datace nejistá) má př́domek "milovaný Vesetem" ${ }^{273}$ Z doby vlád Neferhotepa III. a Mentuhotepa je doložen i termín „vítězný/mocný Veset". ${ }^{274}$ Co se týká samotné vladařské titulatury, tak je doloženo trůnní jméno jednoho z panovníků, které znělo "moc Reova, která zachraňuje Veset"275 (jméno Sechemrešedwaset; datace nejistá) a které explicitně

270 Helck 1975; Ryholt 1997; Redford 1997.

271 Ryholt 1997, 160.

272 Ryholt 1997, 160.

273 Ryholt 1997, 156-157.

274 Ryholt 1997, 306.

275 Ryholt 1997, 305. 
odráží problematické období, kterým toto město a celý region v té době procházely. Titul "vítězný vládce Vesetu" užíval také poslední panovník 17. dynastie Wadžcheperre Kamose ${ }^{276}$ (kolem 1555 př. n. I.) a jeho předchůdce Sekenenre Tao (před 1555 př. n. I.) je z pozdější doby doložen jako „vládce jižního města", tj. Vesetu. 277

Počátek Nové řiše a tedy 18. dynastie je spojen s postupným vytlačením (či s kapitulací a následným volným odchodem?) předovýchodního obyvatelstva a jeho elit ze severního Egypta do prostoru Syropalestiny a zajištěním jižní hranice v Núbii za pomoci válečných tažení prvních panovníků dynastie. Šlo v podstatě o završení úspěšné osvobozovací války na obou frontách, započaté na konci Druhé přechodné doby vesetskými panovníky. Jinými slovy lze také říci, že úspěšný nástup 18. dynastie na vojenském poli měl své kořeny $v$ úspěšné politice posledních panovníků 17. dynastie, pocházejících z vesetského regionu a že její príslušníci plynule navázali na již existující mocenskou sebeprezentaci a rétoriku, jejichž základy byly položeny vesetskými vládci 16. a 17. dynastie. Svoji roli zde sehrál jistě i fakt, že první vládci 18. dynastie, Ahmose I. (asi 1550-1525 př. n. I.) a Amenhotep I. (asi 1525-1504 př. n. I.) byli potomky vládnoucí vesetské dynastie zdatných a houževnatých panovníků konce 17. dynastie (především Sekenenre Taa a Kamose). ${ }^{278}$

Význam Vesetu a vesetského regionu se podle názoru autora mohl signifikantně podílet i na prokazatelném vývoji mocenské sebeprezentace panovníků 18. dynastie. Existující kultovní centrum v dnešním Karnaku, které bylo podle dokladů nejpozději od První přechodné doby zasvěceno bohu Amonovi (ačkoliv počátky jeho uctívání nejsou přesně známy a mohou sahat i hlouběji do minulosti) a také bohu Moncuovi, jehož lokální význam byl zpočátku dokonce větší než Amonův, muselo být panovníky na počátku 18. dynastie vnímáno jako jeden z hlavních důvodů úspěšného zachování samostaného egyptského území s nedotčeným panovnickým úřadem, na což mohli oni plynule navázat. Vedle

276 Helck 1975, 82.

277 Gardiner 1932, 85.

278 Ke genealogii viz Dodson - Hilton 2004, 124-128. 
jiných a neméně důležitých aspektů to byla právě božská přizeň vưči vesetským panovníkům, jejich rezidenci a regionu, která jim umožnila udržet se a posléze i vytlačit cizí vetřelce ze země. Vděčnost panovníků Nové říše vesetským božstvům v čele s bohem Amonem (nejen) za jeho prízeň potom nejvýmluvněji zastupují značná stavební činnost v chrámových komplexech v Karnaku a Luxoru, patřících k největším svého druhu na světě a s tím i úzce související bohatá donační politika těchto vládců.

I když je Amonova pozice na základě archeologických pramenů nezpochybnitelná, podle autorova názoru se zdá, že na vývoj mocenské sebeprezentace či rétoriky egyptských panovníků měla ve Vesetu a vesetském regionu na přelomu Druhé přechodné doby a Nové ríše nezanedbatelný vliv př́tomnost kultu již zmíněného boha Moncua. Uctívání tohoto boha a jeho pozemského vtělení v podobě býka, což je obzvláště důležité, je doloženo nejen $v$ samotném Vesetu, ale i v okolních centrech Armantu, Todu a Medamúdu. ${ }^{279}$ Autor tuto oblast pracovně nazývá jako tzv. „vesetský okruh“.

Býk jako posvátné zvî̃e boha Moncua (eg. $b 3$ 3h; řecky Búchis) je doložen již od doby Střední říše, jako Búchis potom až od Ptolamaiovské doby a ikonograficky až od druhé poloviny Nové ríšse. ${ }^{280} \mathrm{Je}$ velice pravděpodobné, že právě na přelomu Druhé přechodné doby a Nové ríše mohl bůh Moncu nabývat na významu díky své válečnické podstatě jako ten, který předává svoji sílu a schopnosti egyptským panovníkům, což bylo v této turbulentní době spíše nutností, a soudobí vesetští vládci, soudě podle dochovaných pramenů, byli vojensky vskutku velmi aktivní a zároveň úspěšní. ${ }^{281}$ Reálné úspěchy tehdejších vesetských panovníků v poli v kombinaci s nábožensko-ideologickým pozadím tedy velmi pravděpodobně vedly k propojení ideálu vítězného panovníka $v$ rovině racionální s nadpozemským obrazem v podobě silného a neprátele drtícího býka, jenž byl od nejstarších dob přímou personifikací

\footnotetext{
279 Wilkinson 2003, 204.

280 Wilkinson 2003, 172-173.

${ }^{281} \mathrm{~K}$ diskuzi 0 „vojenské“ podstatě vesetských panovníků během Druhé přechodné doby viz Morenz 2010.
} 
egyptského vládce. ${ }^{282}$ Vytvoření takového vzoru zcela určitě dodávalo vesetským vládcům značné psychologické a ideové podpory, násobené navíc oporou v řádu Maat a ospravedlňujícím tak konání vesetských vládců v rovině lidské i božské.

Výše zmíněná úloha býka jako pozemské personifikace egyptského panovníka a současně i živoucího obrazu boha Moncua a jeho probíhající kult ve Vesetu a jeho regionu mohli podle názoru autora rozhodujícím způsobem ovlivnit vytvoření nového prvku v tzv. Horově jménu na počátku 18. dynastie. Tzv. Horovo jméno bylo první z pěti jmen egyptské panovnické titulatury, která se vytvořila již během Staré řišse a která byla základním ukazatelem egyptského vladařského úřadu a zároveň i individuální jedinečnosti každého egyptského panovníka. Tato „novinka“ je poprvé doložena u třetího panovníka 18. dynastie Aacheperkare Thutmose I. (asi 1504-1492 př. n. I.), který si jako první vládce v dějinách Egypta zvolil za Horovo jméno označení $k 3$ nht , termín překládaný většinou jako "mocný býk” (k tomuto označení viz níže). ${ }^{283}$ Toto Horovo jméno je potom v pramenech doloženo až do vlády římského císaře Claudia (41-54 n. I.), ${ }^{284}$ což reflektuje jeho význam a podtrhuje určitou kontinuálnost, která je pro staroegyptskou společnost v mnoha ohledech charakteristická. Jedinou výjimku v rámci 18. dynastie tvoří panovnice Maatkare Hatšepsut (asi 1473-1458 př. n. I.), která si jako Horovo jméno zvolila označení „mocná (svými) ka” (eg. wsrt k3w) a to snad z důvodu jejího neztotožnění se se spíše mužsky vnímaným obrazem býka a to i přes to, že se paradoxně snažila do značné míry na svých portrétech potlačovat svoji ženskost.

Autor se při interpretaci označení $k 3$ nht přiklání k významu „vítězný býk" ${ }^{285}$ a to na základě následujících indicií. Původ tohoto jména je pod-

282 Jako př́klad par excellance zde můžeme zmínit slavnou tzv. Narmerovu paletu z doby kolem roku 3000 (Káhira JE 32169), zaznamenávající patrně moment sjednocení Egypta a téma býků útočících na nepřátele a opevnění.

283 Tento př́domek si podle dochovaných pramenů Thutmose I. zvolil pravděpodobně bud' na samotném počátku vlády, nebo nedlouho po svém nástupu; viz. např. Sethe $1906,82,87,88$.

284 Schneider 2002, 289.

285 K termínu viz např. Lorton 1974, 39. 
le autora nutné hledat zpětně v politické situaci Druhé přechodné doby a v epitetech vesetských vládců (viz výše). Jak bylo zmíněno, během tohoto období se z Vesetu stalo regionální mocensko-kultovní centrum, které sehrálo jedinečnou úlohu v celkovém dějinném vývoji Egypta. Spojení boha Moncua-býka s Vesetem, který představoval centrum úspěšné rezistence a znovudobytí egyptského území na přelomu Druhé přechodné doby a především na počátku Nové řišse, tak mohlo vykrystalizovat v silný ideologický nástroj, který akcentoval jak náboženské, tak i politické ovzduší tehdejší turbulentní doby a který se mohl později odrazit i v Horově jménu Thutmose I.

Důležitými a neopomenutelnými v této mozaice jsou navíc ještě dva střípky, které je třeba při celkové interpretaci zvážit a těmi jsou jednak osobní jméno posledního panovníka 17. dynastie Kamose (eg. $k 3$ ms; kolem 1555 př. n. I., viz výše) a také Horovo jméno druhého panovníka 18. dynastie Džeserkare Amenhotepa I. (asi 1525-1504 př. n. I.), tedy přímého předchůdce zmíněného Thutmose I. V případě panovníka Kamose je možné jeho jméno přeložit jako „zrozený býk” či snad také jako „býk (jej) zrodil”, přičemž slovo býk může být reminiscencí na výše uvedeného boha Moncua-býka, uctívaného také ve Vesetu. Horovo jméno Amenhotepa I. potom zní "býk, který poráží země” (eg. kз wef $t 3 w)$ a opětovně může souviset bud's bohem Moncuem-býkem, nebo v tomto prípadě může jít i o určitý legitimizační nástroj a přihlášení se k „válečnému programu“ panovníka Kamoseho, který představuje zásadní osobnost z hlediska úspěšného boje proti egyptským neprátelům na severu i na jihu. Současně Amenhotep I mohl tohoto ideového prvku záměrně využít v novém mocenském kontextu. ${ }^{286}$ Je velmi pravděpodobné, že ze všech zmíněných skutečností při volbě svého Horova jména vycházel i Thutmose I, kterého Ize bez váhání označit za skutečného zakladatele úspěšných a zcela přelomových egyptských zahraničních výbojů Nové řišse.

${ }^{286}$ Informace 0 zahraniční politice Amenhotepa I. jsou známy především z nápisů v soukromých hrobkách vojáků Ahmose, syna Abany a Ahmose Pennechbeta z el-Kábu, viz Sethe 1906, 6-7, 35. Amenhotepovi I. bývá také připisován fragmentární nápis z bloků brány v Karnaku, zmiňující přinášení tributu z oblasti Syropalestiny, viz Redford 1979. 
Své vojenské úspěchy dal Thutmose I. nejotevřeněji najevo jednak vztyčením stély na břehu Eufratu na severu (jako první egyptský vládce) ${ }^{287}$ a v Núbii (dnešním Súdánu) na jihu ${ }^{288}$ a také rozsáhlou přestavbou Amonova (i Moncuova) chrámového komplexu ve Vesetu, přesněji v dnešním Karnaku. ${ }^{289}$ Není také vyloučeno, že volba nového Horova jména mohla doprovázet vskutku nebývalou expanzionistickou politiku a měla tak manifestovat nové uspořádání mocenských poměrů Egypta vưči sousedním zemím a především postavení egyptského panovníka v jejich rámci. Na základě těchto postřehů se tedy autor přidržuje již používané interpretace označení $k 3$ nht jako „vítězného býka" a to v souladu se skutečně úspěšnou dobyvatelskou zahraniční politikou prvních vládců 18. dynastie.

\section{Závěr}

Předložený text se snaží načrtnout obecněji schéma možné cesty komplexního vývoje, který byl završen přeměnou Vesetu z provinčního sídla v unifikační centrum a hlavní město mocných panovníků 18. dynastie. Stávající doklady dávají tušit, že samotný Veset a jeho region se významně podílel na vytváření mocenské ideologie a identity lokálních egyptských vládců během neklidného období Druhé přechodné doby, které se do značné míry staly základními stavebními kameny pro následující nástup mocných panovníků 18. dynastie, jejichž pevné kořeny byly zapuštěny právě zde na jihu ve Vesetu.

Všechny dostupné prameny $\mathrm{k}$ tématu a jejich různorodé interpretace zde samozřejmě vyčerpány být nemohou, což ponechává jistý prostor pro následné doplnění dalších poznatků v budoucnosti. Text je postaven především na autorově vlastní interpretaci získaných dat, čímž však není řečeno, že jde o závěry definitivní, ale pouze odrážející současný stav poznání.

287 O př́tomnosti stély Thutmose I. u Eufratu se zmiňuje otevřeně později Thutmose III. (asi 1479-1425 př. n. I.), který dle svých nápisů řeku také překročil; viz Sethe 1906, 697. 288 Sethe 1906, 82-86.

${ }^{289} \mathrm{~K}$ obecnému přehledu stavebních aktivit Thutmose I. a ostatních panovníků 18. dynastie v Karnaku viz Baines - Málek 1996, 90-92. 


\section{Literatura}

Baines, John - Málek, Jaromír 1996: Svět starého Egypta, Praha.

Bourriauová, Janine 2003: „Druhá přechodná doba (asi 1650 - 1550 př. Kr.)”, in: Ian Shaw (ed.), Dějiny starověkého Egypta, Praha, 201-233.

Dodson, Aidan - Hilton, Dyan 2004: The Complete Royal Families of Ancient Egypt, London.

Franke, Detlef 1990: „Erste und Zweite Zwischenzeit - Ein Vergleich“, in: Zeitschrift für Ägyptische Sprache 117, 119-129.

Gardiner, Alan H. 1932: Late -Egyptian Stories[Bibliotheca Aegyptiaca, I], Bruxelles.

Helck, Wolfgang 1975: Historisch-biographische Texte der 2. Zwischenzeit und Neue Texte der 18. dynastie, Wiesbaden.

Illin-Tomich, Alexander 2014 „The Theban Kingdom of Dynasty 16: Its Rise, Administration and Politics", in: Journal of Egyptian History, Vol. 7, Issue 2, 143-193.

Kutnar, František 1997: Mezi Chlumy a Kamennou Hưrou: obraz dějin Mlázovic v Podkrkonoší a okolí, Mlázovice.

Lorton, David 1974: The Juridical Terminology of International Relations in Egyptian Texts through Dyn. XVIII, Baltimore and London.

Morenz, Ludwig D. 2010: „Soldatenkönige, Königsakklamation und eine neue Göttin. Zum Beginn des Zweiten Thebanischen Kleinstaates im 17. Jh. v.Chr", in: Journal of Egyptian History, Vol. 3, Issue 2, 293-320.

Redford, Donald B. 1979: „A Gate Inscription from Karnak and Egyptian Involvement in Western Asia during the Early 18th Dynasty", in: Journal of the American Oriental Society 99/2, 270-287.

Redford, Donald B. 1997: „Textual Sources for the Hyksos Period”, in: Oren, Eliezer D. (ed.), The Hyksos: New Historical and Archeological Perspectives, [University Museum Monograph, 96], Philadelphia, $1-44$. 
Ryholt, Kim S. B. 1997: The Political Situation in Egypt during the Second Intermediate Period, Copenhagen.

Sethe, Kurt 1906: Urkunden der 18. Dynastie [Historisch-Biographische Urkunden], Leipzig.

Schneider, Thomas 2002: Lexikon der Pharaonen, Düsseldorf und Zürich.

Vlčková, Petra 2007: „Thébská oblast před rokem 2000 př. n. I.” a "Thébská oblast v závěru 11. dynastie a ve Střední řǐši", in: Jana Mynářová - Pavel Onderka (eds.), Théby. Město bohů a faraonů / Thebes. City of Gods and Pharaohs, Praha, 36-61.

Wilkinson, Richard H. 2003: The Complete Gods and Goddesses of Ancient Egypt, Cairo. 


\section{Miroslava Šurinová}

\section{Nový pohl'ad na pokladnice v staroegyptských pevnostiach z Strednej ríše v Dolnej Núbii}

Staroegyptská Stredná ríša je známa hlavne ako zlatá doba staroegyptského písomníctva. Architektúra z doby Strednej ríše sa zdá byt menej monumentálna než pyramídy Starej ríše alebo chrámy z Novej ríše. Tento dojem je spôsobený zlým stavom zachovania stavieb z doby Strednej ríše, a tým že najpôsobivejšia skupina stavieb ${ }^{290} z$ tej doby sa nachádzala Dolnej Núbii.

Dolná Nubia je oblast medzi prvým a druhým kataraktom, dnes na území štátu Severný Sudán, ktorá bola úzko spätá s faraónskym Egyptom, aj ked' jeho priamou súčastou sa stala až v období Novej ríše. V Strednej ríši Dolná Nubia tvorila vojenské pásmo či nárazníkovú oblast medzi Egyptom a oblastou kultúry Kerma. Dolná Núbia bola pod egyptskou kontrolou avšak bola osídlená miestnym núbijskym obyvatel'stvom, tzv. skupina C, ktoré nebolo ovplyvnené egyptskou kultúrou. ${ }^{291}$

Prví panovníci Strednej rí̌ee, panovníci patriaci do 11. dynastie, sa vo svojej zahraničnej politike viac sústredili na oblast' Syrio-Palestíny. Do centra pozornosti sa Dolná Núbia dostáva za panovníkov 12. dynastie. ${ }^{292}$ Ťaženia do Núbie v 12. dynastii začali na konci vlády Amenemheta I. a pokračovali za vlády jeho nástupcu Senusreta I., ktorý začal s výstavbou pevností v Dolnej Núbii v rovinnej oblasti medzi prvým a druhým

\footnotetext{
290 Trigger 1976, 66-68.

291 Török 2009, 94.

292 Adams 1977, 176; Török 2009, 84; Willems 2010, 92.
} 
kataraktom. ${ }^{293}$ Tieto pevnosti mali viac-menej pravidelný pravouhlý tvar. Amenemhet II. pokračoval v tažobných expedíciách, k stavbe pevnosti však neprispel. ${ }^{294}$ Je možné, že k menším stavebným úpravám v pevnostiach došlo za vlády Senusret II. Najaktívnejší bol v Dolnej Núbii Senusret III. Do oblasti vyslal niekol'ko expedícií a nechal vybudovat' pevnosti v oblasti druhého kataraktu. ${ }^{295}$ Tieto pevností majú nepravidelný tvar, ktorý bol podmienený terénom. Senusret III. bol neskôr v oblasti uctievaný ako božstvo. ${ }^{296}$ Posledným panovníkom 12. dynastie, ktorý vyslal expedíciu do Núbie bol Amenemhet III. ${ }^{297}$ Za jeho vlády v pevnostiach prebiehali len menšie stavebne aktivity. ${ }^{298}$ Celkovo panovníci 12. dynastie postavili v Dolnej Núbii 13 pevností: Ikkur, Kubban, Aniba, Faras, Serra, Buhen, Mirgissa, Askut, Šalfak, Uronarti, Kumma, Semna a Semna juh. Ďalších pät postavili v oblasti prvého kataraktu a Horného Egypta, avšak tieto poznáme len z písomných prameňov. Najznámejším je zoznam pevností na papyre Berlín 10495. ${ }^{299} \mathrm{~V}$ dobe 13. dynastie nedochádza k novým expedíciám do Núbie ani k novým stavebným aktivitám v pevnostiach. K opusteniu pevností dochádza až na konci 13. dynastie. ${ }^{300}$ Väčšina pevností bola znovu okupovaná v Novej ríši a niektoré i neskôr.

Nubijské pevnosti boli objavené cestovatel'mi a bádatel'mi na konci 19. storočia. ${ }^{301}$ Za krátko nasledovali prvé archeologické výskumy. ${ }^{302}$ Výskumy pokračovali na začiatku 20. storočia, hlavne v 20-tych a 30-tych rokoch do vypuknutia Druhej svetovej vojny. ${ }^{303}$ Ďalším obdobím kedy boli pevnosti skúmané boli 60-te roky 20. storočia. Pevnosti boli

\footnotetext{
293 Trigger 1976, 64-65; Török 2009, 84.

294 Trigger 1976, 66-68.

295 Leprohon 1999, 52-54; Shaw 1991, 11; Török 2009, 85-86.

296 Trigger 1976, 66-68.

297 Leprohon 1999, 52-54.

298 Vogel 2004, 69-71.

299 Williams 1999, 694-698; Vogel 2004, 61; Adams 1977, 176.

300 Trigger 1976, 84.

301 Clarke 1916, 169; Monnier 2010,143-147, 154-155; Emery 1959,10.

302 Dunham - Janssen 1960; Monnier 2010, 143-147.

303 Emery 1981, 95; Clarke 1916, 162; Emery, 1959,10; Monnier 2010, 143-147, 154-155; Reisner 1960, 11-12.
} 


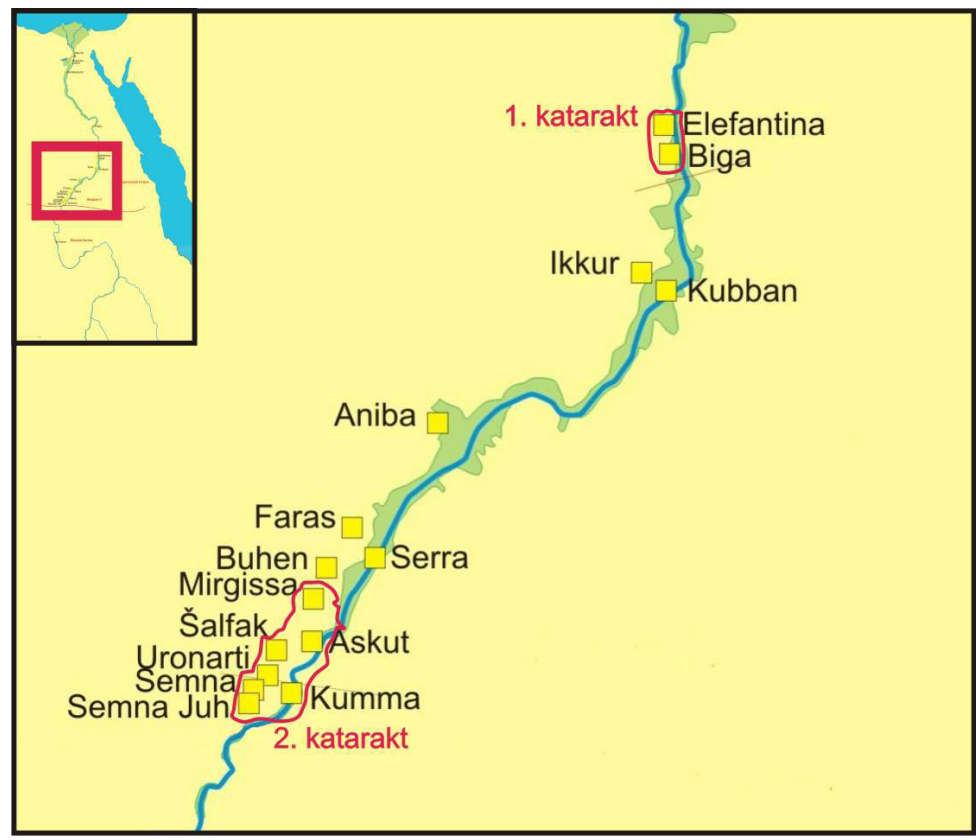

Obrázek 1. Mapa staroegyptských pevností v Dolnej Núbii, Stredná ríša.

skúmané v rámci záchrannej akcie UNESCO ${ }^{304}$ Následne pevnosti zmizli pod vodami Vel'kej Asuánskej priehrady. V roku 1996 Derek Welsby zistil, že dve pevnosti Uronarti a Šalfak sú stále zachované na hladinou Nílu, aj ked' sa dlho verilo, že boli zničené, čo vytvára nádej na získanie nových poznatkov z budúcich výskumov. ${ }^{305}$

Štúdium architektúry pevností sa v čase ich objavenia a výskumu sústredovalo na defenzívne prvky, hlavne na konštrukciu hradieb. Architektúre budov vo vnútri pevností nebola venovaná vel'ká pozornost'. Ak už boli skúmané tak v širšom kontexte daného typu budovy (B. Kemp - sýpky, C. Vogel - budovy velitel'stva). Je to spôsobené tým, že nie

304 Vercoutter - Elhai -Hesse - Karlin - Maley - Vila 1970, v; Vogel 2004, 223-247; Smith 1995, 25.

305 Welsby 2004, 103; C. Vogel 2010, 18. 
všetky pevnosti boli preskúmané dostatočne na to aby sa dali rozoznat všetky budovy, na prvý pohl'ad vel'kou diverzitou budov a zlým stavom zachovania pevností v rovinných oblastiach medzi prvým a druhým kataraktom. ${ }^{306}$ Zložitá je i identifikácia funkcie budov. Drobné nálezy a keramika nie sú spolahlivým indikátorom funkcie, kvôli neskoršej okupácii a pravidelnému čisteniu vnútornej plochy pevností starovekými Egyptanmi. ${ }^{307}$

Jedným z možných spôsobov skúmania architektúry budov v pevnostiach je ich porovnanie s inými vojenskými stavbami. Mnohí bádatelia pripúštali, že sa Nubijské pevnosti podobajú na iné fortifikácie. Emerymu a Patridgovy pripomínali stredoveké hrady v Európe. ${ }^{308}$ Najideálnejšie by bolo porovnat ich s inými staroegyptskými pevnostami. Kedže naše poznanie iných staroegyptských fortifikácii je pomerne skromné, je nutné obrátit sa na fortifikácie iných starovekých národov. $V$ tomto príspevku sa zameriam na porovnanie $s$ rímskou vojenskou architektúrou. Porovnávaniu staroegyptských pevností v Núbii a rímskych pevnosti sa venovali Manassa a Darnell, ktorí sa ale sústredili na funkciu a opevnenie pevností v závislosti na povahe nepriatel'skej hrozby. ${ }^{309}$ Vo fortifikáciách Strednej ríše videli paralelu neskorímských pevností s mohutnými defenzívnymi prvkami, kým neskoršie pevnosti z doby Novej ríše v Núbii pokladajú za paralel fortifikácii z Principátu. Dokonca používajú i pojem Núbijský limes. ${ }^{310}$ Architektúrou budov vo vnútri pevností zo Strednej ríše sa nezaoberali. Tá na rozdiel od ich teórie je viac podobná architektúre rímskych táborov z Principátu než neskorímských pevností.

Rímske fortifikácie sú najprebádanejšími fortifikáciami staroveku. Hoci by sa mohlo zdat, že Rímska armáda bola rozdielna od staroegyptskej, obe armády majú mnoho spoločného. Obe armády mali vysoko rozvinutý administratívny systém a podobnú organizáciu. Štruktúra

\footnotetext{
306 Lawrence 1965, 69.

307 Smith 1995, 54.

308 Emery 1960, 7; Partridge 2002, 130.

309 Darnell - Manassa 2007, 101-102.

310 Darnell - Manassa 2007, 99, 101-102.
} 
staroegyptskej armády je známa až zo záznamov z doby Novej ríše. Avšak predpokladá sa, že sa organizácia armády Strednej ríše, i ked'sa jednalo o nestálu armádu, sa výrazne neodlišovala od jej nástupcu. ${ }^{311}$ Staroegyptská armáda sa skladala z divízii. Jedna divízia mala 5000 mužov. Najmenšia taktická jednotka mala 50 mužov. ${ }^{312}$ Vel'kost' týchto jednotiek nápadne pripomína organizáciu rímskej armády. Typická rímska légia z doby Principátu mala 5300 mužov. Základná taktická jednotka, centuria, mala 80 mužov. ${ }^{313}$ Obe armády používali podobné zbrane: kópie, meče, luky a šípy. Ani jedna nepoznala pušný prach, ktorý je jedným z hlavných faktorov v zmene fortifikačnej architektúry v neskorších obdobiach. Rímske tábory boli stavané z dreva a zeminy s kamennými prvkami. Postupom času začal prevládat' kameň. Staroegyptské pevnosti v Núbii boli stavané z nepálených tehál spevňovaných drevenými trámami a trávou halfa. V oboch prípadoch sa jednalo o lokálne l'ahko dostupné materiály.

Prv než sa začneme zaoberat' tým čo je v oboch typoch fortifikácii podobné, musíme si uvedomit’ rozdiely medzi armádami a ich architektúrou a tak vylúčit budovy, ktoré boli špecifické len pre jednu skupinu. Egyptania nemali také vyspelé vodovodne zariadenia ako Rimania, preto nie je možné v staroegyptských pevnostiach očakávat́ budovy kúpel'ov alebo latrín. Ako toalety Egyptania pravdepodobne používali prenosné keramické nádoby. ${ }^{314} \mathrm{~V}$ egyptských pevnostiach sa nevyskytovali vojenské nemocnice, ale tie boli vzácnostou i v rímskom prostredí (valetudinaria). Budovy stajní, ktorých identifikácia i v rímskom prostredí zostáva predmetom debát, v pevnostiach zo Strednej ríše nenájdeme. K zavedeniu koní do egyptskej armády došlo totiž až v Novej ríši a k zavedeniu jazdy ešte ovel'a neskôr. Na druhu stranu tzv. pracovné tábory (hnnrt "labor prison“), ${ }^{115}$ ktoré sa objavujú

\footnotetext{
311 Počiatky stálej staroegyptskej armády sú často hladané práve v posádkach Nubijských pevností, čo spolu s obliubou Egypṫanov k zachovávaniu tradícii nasvedčuje tomu, že sa vel'kost' jednotiek nezmenila; Spalinger 2013, 421.

312 Partridge 2002, 88; Schulman 1999, 165-167.

313 Johnson 1983, 17.

314 Vogel 2010a, 49-50; Vogel 2004, 139-140.

315 Török 2009, 91.
} 
na staroegyptských pečatidlách v pevnostiach, nemajú v rímskom prostredí obdobu. Budovy skladísk sa v oboch prípadoch identifikujú tažko. V rímskom prostredí sa zdá, že sypký (horrea) plnili i úlohu skladísk. V Núbii skladiskami (wd $3 . w)$ boli pravdepodobne budovy s množstvom dlhých a úzkych miestnosti, ktoré sú známe z Uronarti a z Askutu, kde sa nachádzajú pred hradbami. ${ }^{316}$ Chrámy boli v pevnostiach v Núbii stavané až Novej rišis. ${ }^{317}$ Náboženská funkcia sa často prisudzuje tzv. "libation places". Tieto štruktúry sú tvorené štyri kanálikmi vedúcimi ku kruhovej nádrži. Je však pravdepodobnejšie, že slúžili pri metalurgii. ${ }^{318}$ V rímskom prostredí náboženskú funkciu mala kapla insígnií v budove velitel'stva, princiapiach.

Už na prvý pohlad je zrejme, že rozmiestnenie budov v rímskych táboroch a ani v pevnostiach $\vee$ Dolnej Núbii nebolo náhodné. Oba typy fortifikácii mali vnútornú plochu rozdelenú na bloky sústavou na seba kolmých a paralelných ciest. V rímskom tábore hlavné cesty spájali brány. V staroegyptskej pevnosti taktiež spájali brány, alebo v prípade nepravidelných pevností druhého kataraktu viedli stredom pevnosti. Medzi hradbami a budovami, viedla cesta, ktorá obklopovala celu vnútornú plochu fortifikácie. Rimania ju nazývali via sagularis, v egyptských táboroch je v literatúre často nazývaná poemerium alebo wall street. Pre Rimanov mala väčší význam. Slúžila k rýchlemu presunu vojska vo vnútri tábora. Egyptania ju občas zablokovali schodiskom vedúcim na vrchol hradieb, pristavením budovy hradbe alebo neskoršími stavebnými úpravami. Na presun egyptského vojska slúžil primárne ochodz na vrchole hradby. V celkovom usporiadaní budov vidíme dva opačné prístupy. Rímsky tábor bol plánovaný do stredu. Najdôležitejšie budovy boli umiestnene do centrálne časti, velitel'stvo priamo do stredu. Zostávajúce plochy boli vyplnené barakmi. Egyptania umiestňovali najdôležitejšie budovy k obvodného muru a zostávajúce plochy vnútri boli vyplnené barakmi a menej dôležitými budovami.

\footnotetext{
316 Vogel 2004, 140.

317 Vogel 2010b, 427.

318 Vogel 2004, 142-144; Dunham 1967, 120, 144-145; Wheeler 1961, 115; Dunham - Janssen 1960, 8.
} 


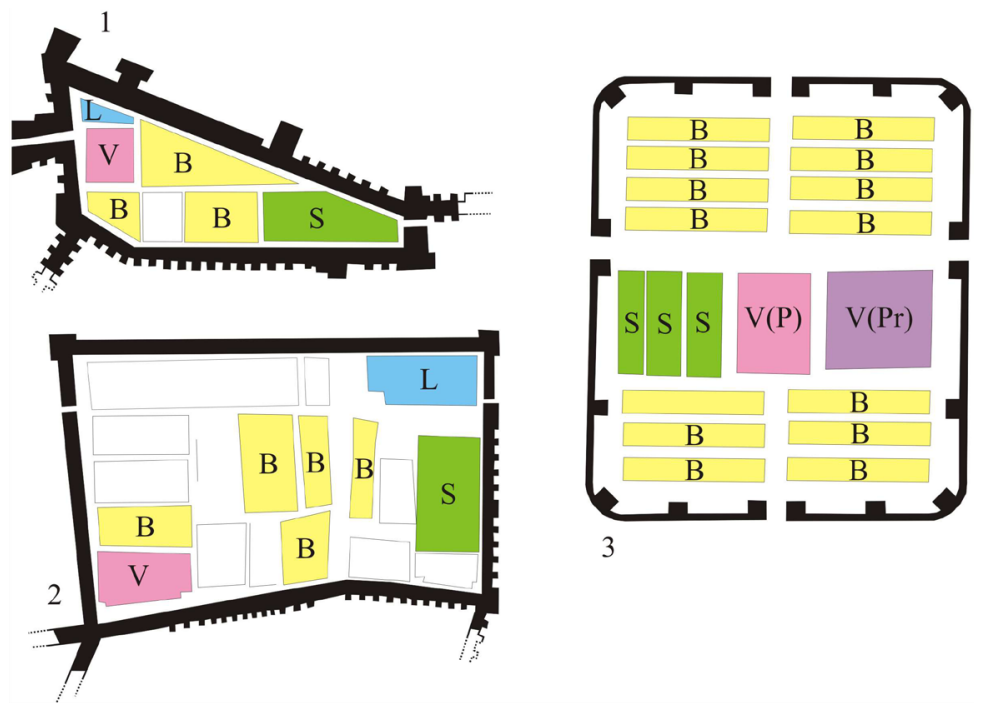

Obrázek 2. Porovnanie usporiadaní budov: 1 - Uronarti, 2 - Mirgissa, 3 - model typického rímskeho auxiliarného tábora, $V$ - velitel'stvo, $\mathrm{V}(\mathrm{P})$ - principia (rímske velitel'stvo), $\mathrm{V}(\mathrm{Pr})$ - praetorium (obydlie velitela), B - baraky, S - sýpka, L - sklad.

Hlavnou podmienkou umiestnenia velitel'stva $v$ staroegyptských pevnostiach v Núbii bol priamy prístup k hradbám. ${ }^{319}$ Preto bývali často umiestnené do rohu pevností. Jedná sa vždy o najväčšiu a najhonosnejšiu budovu v pevnosti. Táto budova slúžila ako hlavé administratívne centrum a obydlie velitel'a pevnosti. Všetky známe budovy velitel'stva mali aj poschodie, ktoré sa však ani v jednom nezachovalo. ${ }^{320}$ Architektonicky sa budova velitel'stva podobná luxusným domom zo Strednej ríše z Kahunu ${ }^{321}$ a Abydu ${ }^{322}$ Centrom budovy bola vel'ká miestnost' so stípmi, zvyčajne v centre stavby. Obklopovali ju dlhé chodby, schodiská a menšie miestnosti identickej vel'kosti a tvaru. Rímska budova velitel'stva,

\footnotetext{
${ }^{319}$ Vogel 2004, 128; Vogel, 2010a, 42.

320 Vogel 2004, 128; Vogel, 2010a, 42.

321 Kemp 2006, 213-215; Uphill 2001, 29-30.

322 Kemp 2006 223; Bard 2008, 189.
} 


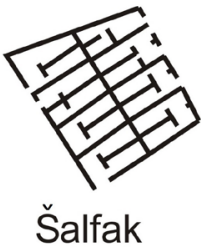

$\longmapsto 10 \mathrm{~m}$

\section{contubernium}
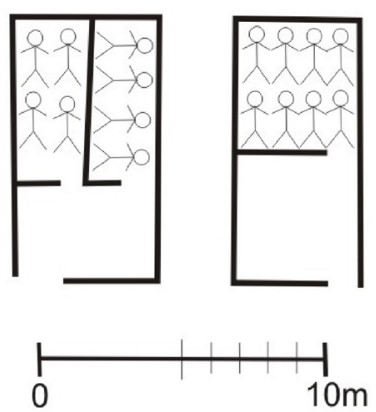

Obrázek 3. Porovnanie staroegyptských barakov a rímskych barakov (contubernii).

princiapia, bola administratívnym a náboženským centrom tábora. Jej architektonická forma, centrálny dvor s portikom, bola odvodená od fóra. ${ }^{323}$ Obydlie velitela, praetorium, bolo oddelené. Tato budova mala architektonickú formu rímskeho luxusného obytného domu. ${ }^{324} \mathrm{~K}$ oddeIeniu obydlia velitel'a a budovy velitel'stva došlo v dobe republiky, kedy bolo potrebne oddelit súkromnú a oficiálnu sféru. V egyptskom prostredí bola funkcia úzko spätá s osobou, ktorá ju vykonávala. K rozdeleniu budov teda nedošlo. Obe obydlia velitel'ov architektonicky vychádzali zo súdobej luxusnej architektúry.

Bežný vojaci oboch starovekých armád boli ubytovaný v omnoho skromnejších stavbách. Baraky, v rímskom prostredí nazývané contubernia, boli v oboch prípadoch dlhé budovy tvorené z totožných buniek. Rímske baraky mali viac menej určený počet buniek. Jeden barak bol určený pre jednu centuriu, teda pre 80 mužov plus velitela centurie centuriona. Na rozdiel od staroegyptských mali rímske baraky na konci väčšiu bunku, ktorá býva interpretovaná ako obydlie centuriona. Bežná bunka bola tvorená predsieňou a hlavnou miestnostou, pričom obe mohli mat rovnaké rozmery, i ked' bolo obvyklejšie, že predsieň bola menšia. Hlavná miestnost' slúžila na spánok a odpočinok. Predsieň

323 Johnson, 1983, 104-113; Bidwell 2007, 72-74.

324 Johnson, 1983, 132-134; Campbell 2009, 37-41; Bidwell 2007, 56-60. 
slúžila na skladovanie výstroja a prípravu jedla. Jedna bunka slúžila ako ubytovanie pre 8 vojakov. ${ }^{325}$ Celkový tvar barakov v pevnostiach v Núbii je menej pravidelný. Ich tvar bol často prispôsobovaný tvaru pevnosti. ${ }^{326}$ Počet buniek je taktiež rozdielny. Základná bunka sa skladala z troch miestností: dvoch identických izieb a priečne umiestnenej predsiene. Izby slúžili na spánok a predsieň pravdepodobne, na základe paralely z uniformných ubytovní pre robotníkov na lokalite Oasr el-Saga, na prípravu jedla. ${ }^{327}$ Počet mužov v jednej bunke môžeme len odhadovat'. Najlogickejším sa zdá byt' 8 mužov na bunku, a to na základe vel'kosti jednotlivých izieb. Izby nepresahujú rozmer 2 x $5 \mathrm{~m}$. Aby si vojaci neprekážali a aby boli schopní rýchlo miestnost' opustit' ideálnym počtom sa zdá byt' 4 muži, pokial' počítame minimálnu plochu na spanie pre jedného 1 x 1,7m. Počet by sa dal znásobit' použitím poschodových postelí, ako sa to často navrhuje pre rímske vojsko. Avšak nemáme žiaden dôkaz, že by Egyptania poschodové postele poznali. Pri počte 8 mužov na bunku, pre najmenšie pevnosti Šlafak a Askut, skoro totožnej vel'kosti, vychádza vel'kost' posádky medzi 48 a 60 mužmi, čo je blízko k 50 mužom v základnej taktickej jednotke. K tomu je potrebne pripočítat́ minimálne velitela jednotky a pisára, ktorý mohli mat' samostatné izby. Pokial' by tento počet naozaj platil, je to až zarážajúce, že 8 mužov na bunku je zhodné ako u Egyptanov tam u Rimanov.

Sýpky sú l'ahko rozpoznatel'né ako v rímskom prostredí tak i v Dolnej Núbii. U Rimanov to boli pravouhlé budovy s piliermi, ktoré podpierali podlahu, kvôli zníženiu vlhkosti, a piliermi pri vonkajšej stene na rozloženie tlaku. ${ }^{328} \mathrm{~V}$ Núbii sa jedná o vel'ké budovy s malými štvorcovými miestnostami a prípadnou väčšiu miestnostou pravdepodobne na administratívne účely. ${ }^{329}$ Jednotlivý bunky boli pravdepodobne plnene z vrchu. ${ }^{330}$ Sýpky v Núbii (šnw.t) sú podobné sýpkam Kahunu. ${ }^{331}$

\footnotetext{
325 Johnson, 1983, 166-168; Bidwell 2007, 60-62.

326 Dunham, 1967, 7-8, 10.

327 Smith 1995, 56; Vogel 2010a, 39.

328 Johnson 1983, 142-144; Campbell 2009, 41-42.

329 Vogel 2010b, 425.

330 Vogel 2010a, 42; Vogel 2004, 134.

331 Smith 1995, 44, 46; Kemp 1986, 121-122.
} 


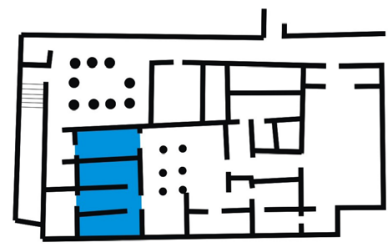

Mirgissa

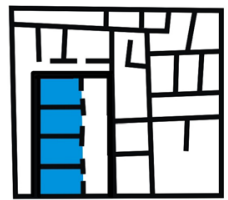

Kumma

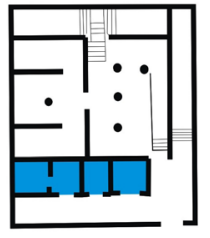

Askut

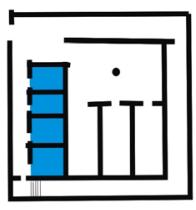

Uronarti

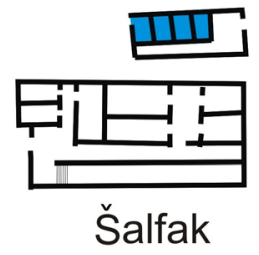

$10 \mathrm{~m}$

Obrázek 4. Navrhované umiestnenie pokladníc.

Skladovali sa v nich prevažne obilniny na výrobu chleba a piva, ale aj sušene ovocie. ${ }^{332}$ Spoločným znakom je posilňovanie stien na rozloženie tlaku v sýpke.

Otázka identifikácie pokladníc (pr-ha $)$ v pevnostiach zo Strednej ríše v Dolnej Núbii zostávala doposial' nevyriešeným problémom. Slovo pokladnica alebo titul pisár pokladnice, či strážca pokladnice sú známe z mnohých pečatí a otlačkov pečatí nájdených v pevnostiach. Isto sa pokladnice nachádzali v Uronarti, Askute, Semne juh a Mirgisse, kde sa okrem slova pokladnica na otlačku vyskytuje i meno pevnosti. Pečate so zmienkou o pokladniciach boli väčšinou nájdene po celej vnútornej ploche pevností. V Uronarti bola väčšia koncentrácia v bloku vedla sýpky. ${ }^{333}$ V Askute mala byṫ väčšina otlačkov v juhovýchodnej

332 Vogel 2004, 134, 136-137.

${ }_{333}$ Vogel, 2010a, 42. 
časti pevnosti, ${ }^{334}$ aj ked' podla publikovaných grafov rozmiestnenie vyzerá rovnomerne po celej ploche pevnosti. ${ }^{335}$ Pokial' sa bádatelia pokúšali o lokalizáciu pokladnice činili tak vždy len v rámci jednej lokality. Carola Vogel za pokladnicu v Uronarti určila blok s najvyššou koncentráciou otlačkov. ${ }^{336}$ Avšak ako v prípade iných budov ani u pokladníc sa nemôžeme spoliehat na drobné nálezy. Pri pokuse o interpretáciu nám v pevnostiach zostáva množstvo kandidátov. Tu sa k slovu dostáva rímska architektúra. $V$ rímskych táboroch bola pokladnica súčastou principii. Jednalo sa o jednu miestnost́ zvyčajne umiestnenú v blízkosti kaple isignií. Občas bola umiestnená pod schodisko alebo podlahu inej miestnosti a tvorila tak akúsi tajnú komoru. Pokladnice nebývali vel'ké. Uskladňovali sa v nich mince určené na plat vojakov a iné drahocenné predmety. Pokladnice v Núbii museli byt väčšie. Egyptania, ktorí nepoznali mince, v nich uskladňovali rozmernejšie predmety. V pokladniciach uschovávali drahocenné predmety nielen pre vlastne vojsko, ale aj predmety ktoré boli predmetom luxusného dial'kového obchodu s Núbiou. Preto je nutne hladat väčšie priestory. Rímska paralela naznačuje, že by sa pokladnice mohli nachádzat' vo velitel'stve. Najlepšou lokalitou kde začat je Askut. Tu sa vo vnútri pevnosti nachádzajú len tri budovy: sýpka, baraky a velitel'stvo. Taktiež je to jedna z lokalít, kde je najviac pečatí a otlačkov pečatí so slovom pokladnica. Budova velitel'stva v Askute patrí tiež medzi tie menej komplikované. Je tvorená troma chodbami, centrálnou miestnostou, menšou miestnostou s jedným stípom a dvoma prilahlými komorami a skupinou štyroch identických miestností usporiadaných v jednom rade. Každá zo štyroch miestností má jeden vstup, tri z prilahlej chodby. Práve táto skupina štyroch miestností má paralely aj v pevnostiach v Mirgisse, Kumme, Uronarti a Šalfaku.

V Uronarti a Mirgisse sa skupina štyroch miestností nachádza v budove velitel'stva. V Šalfaku je umiestnená v samostatnej budove vedla velitel'stva. A v Kumme sa nachádza vo vel'kej budove v južnom rohu

\footnotetext{
334 Smith 1995, 75.

335 Smith 1995, 72-73.

336 Vogel, 2010a, 42; Vogel 2004, 140.
} 
pevnosti, avšak v Kumme nie je jasná funkcia žiadnej z budov okrem sýpky, teoreticky by sa teda mohlo jednat' i o velitel'stvo. Zaujímavé je, že v Kumme je skupina štyroch miestností oddelená od okolia hrubším múrom než sú múry vnútorných budov. To naznačuje, že bolo potrebné tieto štyri miestnosti chránit́. V Kumme, Uronarti a Šalfaku má každá miestnost́ zo skupiny jeden vchod z chodby. Zároveň tvar týchto miestností a miestností v Askute je podobný. Jedná sa o krátke obdližniky, ktoré pripomínajú skôr štvorec. Skupina štyroch miestnosti v Mirgisse je trošku odlišná. Miestnosti sú viac podlhovasté a vstupy majú zdajú mat́ menej pravidelné usporiadanie a počet. Mirgissa však patrí k pevnostiam na pláňach medzi prvým a druhým kataraktom postavených za Senusreta I., pričom všetky ostatné spomínané lokality sú pevnosti druhého kataraktu postavené za Senusreta III. Je teda možné, že postupom času došlo k menšej zmene stavebného typu a väčšej štandardizácii. Kvôli tomu, že sa táto skupina štyroch identických miestností nachádza vo viacerých pevnostiach, ich umiestnení v alebo pri budove velitel'stva a posilnenej ochrane skupiny v Kumme sa domnievam, že práve táto skupina štyroch miestností slúžila ako pokladnica. Umiestnenie pokladnice pod priami dozor velitela pevností sa zdá byt' logické a má paralelu v rímskej vojenskej architektúre. Vel'kost' by taktiež zodpovedala. Miestnosti sú dohromady väčšie než rímske pokladnice, avšak sú omnoho menšie než sýpky v Núbii, kde sa uskladňovalo jedlo a iné nedrahocenné zásoby. Budúce výskumy na lokalitách Šalfak a Uronarti by túto teóriu mohli potvrdit' podrobnejším skúmaním danej skupiny štyroch miestností.

Z doby Strednej ríše možno pochádza ešte jedná fortifikácia, ktorú je nutné zmienit pri porovnávaní s rímskou vojenskou architektúrou: pevnost' vo Wadi al-Hudi. Oblast' Wadi al-Hudi bola skúmaná Murrayom v 1938-39, 337 Fachrym v 1944-1949338 a týmom Cambridgeskej univerzity v 1975. ${ }^{339}$ Avšak ani v jednom prípade nešlo 0 archeologické vykopávky. Jednalo sa len o zbežné zmapovanie lokality a jej predbežné datovanie

\footnotetext{
337 Fakhry, 1952, 1-4.

338 Fakhry, 1952, 1-4.

339 Shaw - Jameson 1993, 84.
} 


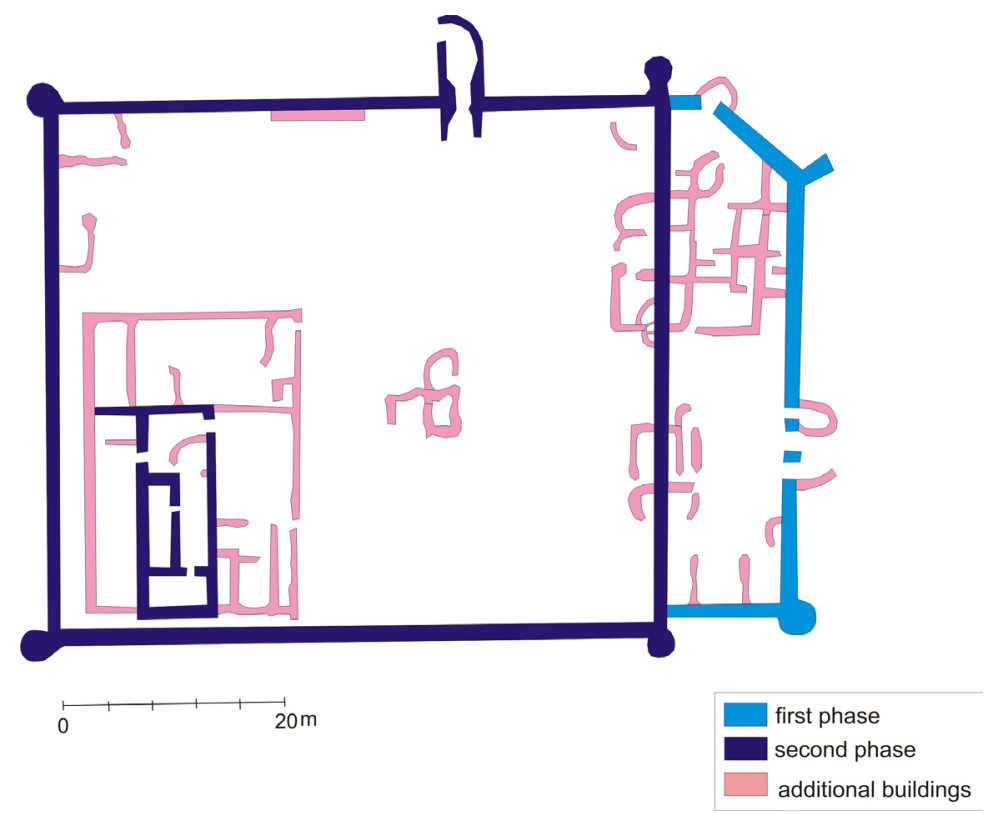

Obrázek 5. Pevnost' vo Wadi al-Hudi.

založené na povrchovej keramike. ${ }^{340}$ Lokalita bola osídlená v Strednej ríši a Rímskej dobe. V celej lokalite Wadi al-Hudi sa nachádza viacero stavieb. Niektoré stavby boli datované čisto do Strednej ríše, niektoré čisto do Rímskej doby, ale sú i také ktoré obsahovali keramiku z oboch období. Malá kamenná pevnost je na lokalite najväčšou stavbou. Pevnost' postavená $z$ kameňa $v$ dvoch fázach. ${ }^{341}$ Zvyčajne je datovaná do doby Strednej ríše. ${ }^{342}$ Avšak architektonicky nápadne pripomína rímske praesidia vo východnej púšti v Egypte. Bolo by teda lákavé datovat' stavbu do rímskej doby. ${ }^{343}$ Lenže prevažná väčšina keramiky z plochy pevností bola datovaná do Strednej ríše. Hlavným oporným argumentom pre staroegyptskú datáciu sú striel'ne pre lukostrelcov, ktoré sú

\footnotetext{
340 Shaw - Jameson 1993, 95-96.

341 Shaw - Jameson 1993, 88-89, 91; Vogel 2004, 204-205.

${ }^{342}$ Fakhry 1952, 7-12, 14-17; Shaw - Jameson 1993, 86; Vogel 2004, 204-205.

343 Morkot 2003, 249.
} 
zachované v južnom a západnom múre. Rímske praesidia vo Východnej púšti striel'ne nemali. Podl'a popisov by striel'ne z Wadi al-Hudi mali byt' podobné strielňam Núbijských pevností z doby Strednej ríše, i ked'nebolo publikované žiadne ich vyobrazenie. ${ }^{344}$ Vysvetlením architektonickej podobností by mohlo byt', že staroegyptská fortifikácia vo Wadi al-Hudi bola inšpiráciou pre rímske praesidia.

Skúmanie architektúry staroegyptských pevností v Dolnej Núbii je komplikovaná úloha, kvôli nemožnosti nových výskumov, priamej návštevy väčšiny lokalít a nerovnomerne publikovaných výskumov z minulého storočia. Avšak pri porovnaní s architektúrou iných fortifikácii, v tomto prípade s rímskymi, sa dá dospiet k nový záverom. Zdá sa, že staroveké armády si boli podobnejšie než by sa dalo čakat', čo sa odrazilo aj na architektúre. Architektúra budov vo vnútri pevností si je bud' vel'mi podobná, ako baraky, alebo vychádza z rovnakých princípov, ako sýpky a obydlia velitel'a pevnosti. Rímska vojenská architektúra mi pomohla i pri vytvorení teórie o polohe pokladníc v staroegyptských pevnostiach zo Strednej ríše v Dolnej Núbii. Na záver jeden drobný detail, ktorý dokazuje, že i ked’ vojaci staroegyptskej armády a rímskej armády boli časovo od seba vzdialený cez dve milénia, boli v podstate podobní. Vo veži pri bráne v pevnosti Mirgissa bola objavená do podlahy vrytá hracia plocha na staroegyptskú hru senet. ${ }^{345}$ Hracia plocha, síce na inú hru, bola objavená na podlahe rímskeho tábora v Abu Shaar u na pobreží Červeného mora. ${ }^{346}$ Tieto objavy poukazujú na to, že vojaci oboch armád sa na hliadkach nudili a chvíle si krátili hraním hier.

344 Shaw - Jameson 1993, 86, 88-89.

345 Vogel 2010a, 51.

346 Sidebotham - Hense - Nouwens 2008, 58. 


\section{Bibliografia}

Adams, William Yewdale 1977: Nubia: Corridor to Africa, London.

Bard, Kathryn A. 2008: An Introduction to the Archaeology of Ancient Egypt, Oxford.

Bidwell, Paul 2007: Roman Forts in Britain, Chalford.

Campbell, Duncan B. 2009: Roman Auxiliary Forts 27 BC-AD 378, Oxford.

Clarke, S. 1916: „Ancient Egyptian Frontier Fortresses“, in: Journal of Egyptian Archaeology 3, 155-179.

Darnell,JohnColeman-Manassa, Colleen2007: Tutankhamun'sArmies: Battle and Conquest During Ancient Egypt's Late Eighteenth Dynasty, Oxford.

Dunham, Dows 1967: Second Cataract Forts, Volume 2: Uronarti, Shalfak, Mirgissa. Excavated by George Andrew Reisner and Noel F. Wheeler , Boston.

Dunham, Dows - Janssen, J. M. A. 1960: Second Cataract Forts. Volume 1: Semna, Kumma, Boston.

Emery, Walter Bryan 1981: „Buhen, Kor, the Nubian Survey, Ibrim”, in: L. Habachi (ed.), Actes du lle Symposium International sur la Nubie (Février 1-3, 1971), Cairo, 95-108.

Emery, Walter Bryan 1960: „Preliminary Report on the Excavations of the Egypt Exploration Society at Buhen, 1958-9", in: Kush 8, 7-10.

Emery, Walter Bryan 1959: „Preliminary Report on the Excavations of the Egypt Exploration Society at Buhen, 1957-8", in: Kush 7, 7-14.

Fakhry, Ahmed 1952: The Inscriptions of the Amethyst Quarries at Wadi El-Hudi, Cairo.

Johnson, Anne 1983: Roman Forts, London.

Kemp, Barry J. 2006: Ancient Egypt: Anatomy of a Civilization, London - New York. 
Kemp, Barry J. 1986: „Large Middle Kingdom Granary Buildings (and the archaeology of administration)", in: Zeitschrift für ägyptische Sprache und Altertumskunde 113, 120-136.

Lawrence, A. W. 1965: „Ancient Egyptian Fortifications”, in: Journal of Egyptian Archaeology 51, 69-94.

Leprohon, Ronald J. 1999: „Middle Kingdom, owerview“, in: Kathryn A. Bard (ed.), Encyclopedia of the Archaeology of Ancient Egypt, London - New York, 50-56.

Monnier, Franck 2010 : Les forteresses égyptiennes: Du Prédynastique au Nouvel Empire, Brussels.

Morkot, Robert G. 2003: Historical Dictionary of Ancient Egyptian Warfare. Historical Dictionaries of War [Revolution, and Civil Unrest 26], Lanham - Oxford.

Partridge, Robert B. 2002: Fighting Pharaohs. Weapons and Warfare in Ancient Egypt, Manchester.

Reisner, George Andrew 1960: "The Egyptian Forts from Halfa to Semna, Edited by Dows Dunham", in: Kush 8, 11-24.

Schulman, Alan 1999: „Army“, in: Kathryn A. Bard (ed.), Encyclopedia of the Archaeology of Ancient Egypt, London - New York, 165-167.

Shaw, lan - Jameson, Robert 1993: „Amethyst Mining in the Eastern Desert: A Preliminary Survey at Wadi el-hudi", in: Journal of Egyptian Archaeology 79, 81-97.

Shaw, lan 1991: Egyptian Warfare and Weapons [Shire Egyptology 16], Princes Risborough.

Sidebotham, Steven E. - Hense, Martin - Nouwens, Hendrikje M. 2008: The Red Land: The Illustrated Archaeology of Egypt's Eastern Desert, Cairo.

Smith, Stuart Tyson 1995: Askut in Nubia. The Economics and Ideology of Egyptian Imperialism in the Second Millennium B.C., London - New York.

Spalinger, Anthony J. 2013: „The Organisation of the Pharaonic Army (Old to New Kingdom)", in: Juan Carlos Moreno García (ed.), Ancient Egyptian administrativ, Leiden, 393-478. 
Trigger, Bruce G. 1976: Nubia under the Pharaohs, London.

Török, László 2009: Between Two Worlds. The Frontier Region between Ancient Nubia and Egypt 3700 BC-500AD, Leiden - Boston.

Uphill, Eric Parrington 1988: Egyptian Towns and Cities, Princes Risborough.

Vercoutter, Jean-Elhai, H. - Hesse, A. - Karlin, C. - Maley, J. - Vila, A. 1970: Mirgissa I, Paris.

Vogel, Carola 2010b: „Master architects of Ancient Nubia: Spacesaving solutions in Middle Kingdom fortresses", in: W.Godlewski and A.Lajtar (eds.), PAM Supplemnt Series 2.2/2, Warsaw, 421-430.

Vogel, Carola 2010a: The Fortifications of Ancient Egypt 3000-1780 BC, Botley - Oxford.

Vogel, Carola 2004: Ägyptische Festungen und Garnisonen bis zum Ende des Mittleren Reiches, Hildesheim.

Welsby, Derek A. 2004: „Hidden Treasures of Lake Nubia“, in: Sudan \& Nubia 8, 103-104.

Williams, Bruce B. 1999: „Nubian Forts”, in: Kathryn A. Bard (ed.), Encyclopedia of the Archaeology of Ancient Egypt, London - New York, 694-700.

Willems, Harco 2010: „The First Intermediate Period and the Middle Kingdom", in: Alan B. Lloyd (ed.), A Companion to ancient Egypt 1, Chichester - Malden, 81-100.

Wheeler N. F. 1961: "Diary of the Excavation of Mirgissa Fort 14 November 1931 to 3 February 1932. By the Harvard University-Museum of Fine Arts Expedition Recorded by Noel F. Wheeler", in: Kush 9, 87-179. 
3. KAPITOLA

KONTAKTY ZÁPADU

A VÝCHODU 
Ivo Budil

\section{William Winwood Reade a formování britské afrikanistiky}

Podtitul mého příspěvku by mohl znít „setkání viktoriánského intelektuála a sociálního darwinisty s černou Afrikou a co z toho vzešlo". Zatímco raný novověk byl ve znamení „dobytí Ameriky" se všemi geopolitickými, ekonomickými, sociálními a ideologickými důsledky, pro počátek moderní doby je charakteristická směs rasové arogance, imperialismu, filantropie a vykořistování, které doprovázely kolonizaci subsaharské Afriky. Evropská zámořská expanze raného novověku se rozsáhlých oblastí subsaharské Afriky dotkla na rozdíl od jiných kontinentů jen nepatrně. Zatímco severní Afrika přiléhající ke Středozemnímu moři byla z větší části politicky ovládána Osmanskou řiší, na pobřeží východní Afriky podél Indického oceánu pronikali po staletí arabští kupci, kteří rozvíjeli rozsáhlý obchod s otroky a šririli islám mezi domorodé komunity. Evropané vybudovali od patnáctého století především v Guinejském zálivu řadu obchodních stanicí a ozbrojených základen umožňujících začlenit africké vnitrozemí do atlantického hospodářského prostoru, jehož součástí byl rovněž Nový svět. Vytěžení prírodního bohatství Ameriky by bylo bez extenzivního využití otrocké pracovní síly pocházející ze subsaharské Afriky obtižně představitelné. Na samotném jižním cípu afrického kontinentu na místě dnešního Kapského Města založila v roce 1652 nizozemská Sjednocená východoindická společnost stanici střežící strategicky důležitou námořní trasu do Indie.

Kromě politických struktur, které na sever a východ Afriky importovali muslimové, existovalo tradiční centrum státní moci v Habeši. Městská 
střediska těžící z dálkového obchodu a imitující islámské vzory se rozvíjela mezi Saharou a jižní pralesní zónu především podél středního a horního toku řeky Niger. Zbývající oblasti Afriky ovládali místní náčelníci, z nichž občas některému z nich umožnily příznivé podmínky, příhodná príležitost nebo osobní ambice vytvořit centralizovanější či geograficky rozsáhlejší politické útvary, jejichž životnost byla ale většinou omezená. Až do devatenáctého století představoval jedinou významnou vnější civilizační sílu na půdě Afriky islám, který ovlivňoval sever a východ kontinentu a postupně pronikal do jeho středu. Islamizace Afriky byla procesem relativně pomalým, ale vytrvalým. Obtǐnný a neprostupný terén, tropické podnebí a především smrtelné choroby Evropany od afrického vnitrozemí dlouho odrazovaly. Průmyslová revoluce, abolicionismus a rivalita mezi západními mocnostmi, která vyústila od sedmdesátých let devatenáctého století do nového asertivního zámořského imperialismu, v historicky krátké době radikálně změnila politickou mapu a historické osudy černé Afriky.

Od konce osmnáctého století stále více evropských cestovatelů pronikalo do neprozkoumaného afrického vnitrozemí. Imaginární geografie těžící z legend a dohadů byla nahrazována konkrétními kartografickými údaji. Mungo Park, skotský lékař a absolvent univerzity v Edinburghu, prozkoumal v letech 1795 až 1805 povodí řeky Niger. Jeho Cesty do nitra Afriky dosáhly značné popularity. Anglický kapitán James Hingston Tuckey zemřel v roce 1816 během plavby po řece Kongo.

Richard Francis Burton a John Hanning Speke dosáhli roku 1857 břehů jezera Tanganyika. V následujícím roce objevil Speke Viktoriino jezero a v letech 1860 až 1863 John Hanning Speke a James Augustus Grant prošli od Viktoriina jezera podél toku Nilu až ke Středozemnímu moři. Německý cestovatel Gustav Nachtigal zkoumal v letech 1869 až 1874 Saharu a súdánskou provincii Kordofán. ${ }^{347}$

Vzhledem k ekonomickému a mocenskému vzestupu Evropy v devatenáctém století nebylo reálné, že by si subsaharská Afrika uchovala relativní izolaci, do níž kontinent upadl poté, kdy Evropané a Američané

347 Pakenham 1991. 
ztratili zájem na další využívání otrocké pracovní síly. Vlivné obchodní a finanční kruhy by dřive či později začalo pritahovat africké př́rodní bohatství. Kolonizace černého kontinentu, která od poloviny osmdesátých let devatenáctého století přešla do proslulé „rvačky o Afriku” (scramble for Africa). Termín „scramble for Africa“ použil poprvé Parker Gillmore v zárí 1884 v listu Times.

Mužem, který se bezpochyby nejvíce zasloužil o „otev̌̌ení” Afriky Západu se všemi dramatickými geopolitickými důsledky, byl legendární skotský misionáŕ, lékař a cestovatel David Livingstone. Tento přesvědčený abolicionista věril, že trojice "křestanství, obchod a civilizace" (commerce, Christianity, civilization) přinesená do Afriky povede k odstranění odpudivého obchodu s otroky, který pokládal za největši zlo černého kontinentu. Jak známo, David Livingstone třicet let zkoumal africké vnitrozemí. V roce 1858 objevil jezero Nyasa. V polovině šedesátých let devatenáctého století ztratil spojení s vnějším světem a byl pokládán za mrtvého.

V listopadu 1871 jej „nalezl“ americký novináŕ pracující pro New York Herald Henry Morton Stanley. $V$ této době chinin léćící malárii a parník umožnující plavby po místních řekách odčarovaly zakleté nitro Afriky. Anglický cestovatel Vorney Lovett Cameron, první známý běloch, který v letech 1873 až 1875 přešel Afriku od pobřeží Indického oceánu k vinám Atlantiku, hovořil o nevýslovném bohatství, jež spatřil v povodí Konga. V záŕí 1876 uspořádal Leopold II. v Bruselu první zeměpisnou konferenci o Africe. V úvodním proslovu král prohlásil, že je třeba zahájit křížové tažení, které by rozširíilo pokrok a civilizaci do posledních temných koutů planety. Prítomný Ferdinand de Lesseps označil zvažovanou kolonizaci střední Afriky za "největší humanitární dílo našeho věku" ${ }^{348}$

V sedmdesátých a osmdesátých letech devatenáctého století zmíněná Livingstonova evangelizační mise řadu mladých Anglosasů již neuspokojovala. Toužili po dobrodružství a vykonání velkého díla, ale nikoliv s Biblí v ruce. Byli osloveni sociálním darwinismem, vírou, že základem existence je rivalita a boj o přežití, nikoliv náboženská

348 Pakenham 1991. 
sentimentalita. Vzorem jim byl Cecil Rhodes. Rudyard Kipling byl jejich básníkem. Lawrence z Arábie posledním exemplárem.

William Winwood Reade byl intelektuálem vzešlým z jejich řad. Narodil se 26. listopadu 1838 v Murrayfieldu pobliž Crieffu ve Skotsku v zámožné rodině. Mnozí jeho príbuzní pưsobili ve službách Východoindické společnosti. William Winwood Reade zahájil v březnu 1856 studium na Magdalen Hall v Oxfordu. Nedokončil jej. Toužil po literární dráze. Možná se chtěl vyrovnat svému strýci Charlesi Readovi (1814-1884), který se v této době proslavil jako dramatik. V roce 1859 napsal Winwood Reade povídku Charlotte a Myra. Následoval román z univerzitního prostředí Liberty Hall, Oxon (1860). Prošel zednářskou iniciací. Pravděpodobně tato zkušenost inspirovala Reada k románu Isidin závoj (The Veil of Isis) zasazeného do světa archaických druidů, údajných předchůdců zednár̆ŭ ${ }^{349}$ Kniha znamenala rozchod s anglikánskou církví. Žádné z dosavadních Readových děl nemělo úspěch.

$\checkmark$ roce 1859 vydal Charles Darwin studii 0 původu druhů. Jedním z nejdiskutovanějších a nejkontroverznějších Darwinových tvrzení bylo to, že se člověk vyvinul z opičího prédka. Právě tehdy vystavil francouzský cestovatel Paul DuChaillu v Londýně tři vycpané exempláre gorily, dosud neznámého druhu lidoopa, které príivezl z nitra Afriky. Rozpoutala se boư̌livá polemika ne nepodobná pozdějším sporům 0 "sněžného muže”. Paul DuChaillu měl smůlu, protože byl amatérem a (což bylo ještě horší) Francouzem. Byl obviňován z podvodu. Naštěstí nalezl i zastánce, především proslulého zoologa Roberta Owena. Romanticky naladěný William Winwood Reade pojal záměr vypravit se na černý kontinent a presvědčit se osobně o existenci "monstra". V prosinci 1862 vyrazil na lodi Armenian do "srdce temnoty". V Gabonu zjistil, že Paul DuChaillu zakoupil gorilí kǔže od domorodců na pobřeží. Se zvir̃aty se nikdy nesetkal. Winwood Reade pokračoval do Konga ve šlépějích Livingstonových. Navštívil Luandu, důležité středisko obchodu s otroky. Bylo mu čtyřiadvacet let, neuměl arabsky ani žádný africký jazyk a pouze lámaně se dorozuměl portugalsky. Jeho jedinou zbraní byla puška na lov kachen, kterou nikdy

${ }^{349}$ Reade 1910, vii. 
nenabil. Pochopitelně onemocněl zimnicí a následků choroby se již nezbavil.

Do Anglie se Winwood Reade vrátil koncem roku 1863. Své zážitky vylíčil v cestopise Divoká Afrika (Savage Africa). Byl přesvědčen, že existuje jediná cesta, jak integrovat Afriku do světových dějin, a to prostřednictvím islamizace. Portugalské kolonie upadají, britské osady v Evropě stagnují a pouze francouzské državy projevují jistou vitalitu. Pokud by Rusové dobyli Istanbul a posunuli tak těžiště islámského světa do Káhiry, velké reformní dílo egyptského vládce Muhammada Alího by mohlo obsáhnout subsaharskou Afriku a civilizačně ji povznést. Jestliže by Velká Británie uzavřela alianci s muslimy při kultivaci Afriky, kontinent by vzkvétal a civilizačně by se v blízké budoucnosti vyrovnal Eurasii.

Je příznačné, že Winwood Reade stále sdílel starou Buffonovu myšlenku z osmnáctého století, že střední, dosud neprobádaná Afrika, je tvořena rozsáhlou náhorní plošinou s mírným klimatem obývanou archaickou rasou žijící ve skutečném „zlatém věku” a př́buznou se starověkými Egyptany. Černoši podle Readova názoru nejsou samostatnou rasou, ale degradovanou sociální skupinou, obdobou deklasovaných tříd Evropy a Severní Ameriky, která žije pouze v pobřežních oblastech Afriky a kterou v důsledku otrokářství mylně považujeme za obyvatele celého kontinentu.

Zkušenosti z putování jej poučily o důležitosti lékařských znalostí. Trí roky studoval medicínu v St Mary's Hospital v Paddingtonu. Když na podzim 1866 vypukla epidemie cholery, Winwood Reade se přihlásil jako dobrovolník. Pod pseudonymem Francesco Abati vydal román See-Saw (1865), milostný příběh odehrávající se ve Florencii. Čtenáři si knihy nevšimli. Reade zklamaně poznamenal: „Zítra mi bude třicet let. Již více deset let piši a piši a ničeho jsem nedosáhl. Absolutně ničeho. Více než názorně jsem se přesvědčil, že mým údělem je prüměrnost". 350

350 Reade 1910, xii. 
Nezbývalo než odejet opět do Afriky. Tentokrát měl Winwood Reade v úmyslu zůstat na západoafrickém pobřeží a shromáždit zoologické a etnologické sbírky. 0 jeho služby projevil zájem Andrew Swanzy, představitel významné společnosti obchodující s Afrikou. Patronát nad další Readovou cestou, která započala na podzim 1868, převzala Královská geografická společnost. Winwood Reade pobýval zprvu ve Freetownu v Sieře Leone. Během expedice do vnitrozemí dorazil až do města Falaba, kde byl hostem místního panovníka. Chtěl proniknout k pramenům Nigeru. Náhle si však uvědomil, že je vlastně zajatcem. Navíc trpěl postupně úplavicí, neštovicemi a malárií. Naštěstí z Freetownu dorazil posel se vzkazem od guvernéra, aby byl Reade dopraven zpět. Domorodý král si neprál mít s Brity žádné potiže a žádosti vyhověl. Přesto po dvou týdnech strávených ve Freetownu se Winwood Reade vydal znovu pres Falabu k řece Niger. Ostatní Britové pokládali jeho počínání za pokus o sebevraždu, ale Reade se nenechal odradit. Nigeru opravdu dosáhl. "Ted' již nikdo nemůže ř́ci, že jsem pouhým spisovatelem, dokázal jsem, že jsem mužem činu i silné mysli, " poznamenal si ${ }^{351}$ Jediným problémem bylo to, že Winwood Reade zapomněl ve Freetownu sextant. Nemohl tedy Královské geografické společnosti doložit dosaženou polohu. Tím byl třetí z výše zmíněných Readových atributů poněkud zpochybněn. Stojí za zmínku, že William Winwood Reade navštívil rovněž Monrovii, hlavní město Liberie, založené v roce 1822 abolicionisty jako africké útočiště pro propuštěné otroky, a vyjádrill hlubokou skepsi k životaschopnosti zmíněného státu.

V Anglii Winwood Reade uveřejnil Africký deník (African Sketch Book, 1873). Dopisoval si rovněž s Charlesem Darwinem, který raadu Readových poznatkủ použil v Pưvodu člověka. Když vypukla válka s Ašanty, připojil se Winwood Reade v zárí 1873 jako korespondent listu Times a poradce k ozbrojené expedici vedené generálem Garnetem Wolseleyem. Domů se vrátil s podlomeným zdravím. Dopisy, které Reade zasílal do Timesů, vyšly knižně jako Příběh ašantské kampaně (The Story of the Ashanti Campaign). Napsal román Odpadlik (The Outcast, 1875) pojednávající o perzekuci, kterou v Anglii zakoušel jedinec,

351 Reade 1910, xx. 
jenž se vzdal náboženské víry. Winwood Reade zemřel ve Wimbledonu v pětatřiceti letech 24. dubna 1875 jako spisovatel, který nemohl být zapomenut, protože nikdy nebyl známým.

Přesto o jednom Readově díle Cecil Rhodes poznamenal, že z něj učinilo to, čím se stal. Obdivovali jej George Orwell, Herbert George Wells nebo Winston Churchill. Sir Harry Johnston prohlásil, že by po dosažení jednadvaceti let měl povinně dostat jeden výtisk na státní útraty každý mladík a dívka ve Velké Británii a Spojených státech amerických. ${ }^{352}$ 0 Winwoodu Readovi se pochvalně vyjádřil samotný Sherlock Holmes (pravděpodobně jediný literát, kterého velký detektiv, jenž romány nečetl, ocenil): „Pěkně o tom mluví Winwood Reade. Tvrdí, že jednotlivec sice je neřešitelná záhada, ale v množství se z něho stává matematická jistota. Člověk napřiklad nikdy nemǔže předvídat, co udělá jednotlivec, ale může přesně uhodnout, jak se zachová určité množství průměrných lidí. Jedinci se navzájem liší, ale procenta zưstávají konstantní" 353

Již začátkem šedesátých let devatenáctého století během pobytu v Africe začal Winwood Reade přemýšlet o univerzálních dějinách, ve kterých by na základě učení Charlese Darwina vyličil celý příběh člověka od primitivních počátků do zrodu moderní civilizace. Výsledkem byla kniha Mučednictví člověka (Martyrdom of Man) z roku 1872. Text je rozdělen do čtyř rozsáhlých kapitol: Válka, Náboženství, Svoboda a Intelekt. V části označené Válka Winwood Reade popisoval starověké říše až do arabské expanze, v Náboženství se zaměřil na judaismus, křestanství a islám, ve Svobodě se zabýval Germány, středověkou Evropou, Benátkami, portugalskými objevitelskými výpravami, otrokářstvím a abolicionismem a v Intelektu přiblížil zrod života na zemi, evoluci, vznik člověka a budoucnost lidského rodu.

Pokrok lidské rasy byl podle Reada dosažen snahou přežít a vyniknout. Každý zdravý národ je nastaven tak, aby v tomto směru dosáhl co největší výkonnosti. Evropské mocnosti, Velká Británie, Francie, Rusko a Německo, by měly zapomenout na vzájemnou rivalitu a společně realizovat civilizační povznesení světa. Osmanská říše, Čína,

\footnotetext{
352 Reade 1910, xlv.

${ }^{353}$ Doyle 2013, 225.
} 
Maroko, Habeš a Tibet budou jednou osídleny svobodnými, pracovitými a vzdělanými lidmi. To nebude možné bez evropské expanze, která ve skutečnosti představuje emancipaci místního obyvatelstva. Válka je proto klícovým nástrojem dosažení svobody a pokroku na Východě. ${ }^{354}$ Viktoriánský gentleman, který byl již trochu skeptický vưči náboženství, ctil ale tradice a vážil si vzdělání, byl upřímně přesvědčen, že Velká Británie má mimořádnou historickou úlohu, ale k jejímu naplnění je zapotřebí hodně disciplíny, kuráže, sebezapření a občas (je-li to nutné) násilí, nalezl v Mučednictví člověka vynikajícího průvodce dějinami. Bylo to kultivované dílo pro budovatele impéria. Pro dnešního čtenáře, odchovaného rétorikou ironického věku, je Mučednictví člověka těžko stravitelné. Zastaralost informací obsažených v knize nebyla vyvážena mimořádnými literárními kvalitami. Žánrově je dílo obtížň zařaditelné. Autor nebyl ani historik, ani etnograf (jakkoliv byla jeho erudice obdivuhodná). Nebyl ani velký spisovatel, i když musíme uvážit, že stěží dovršil třiceti let. Ve svých nejlepších pasážích připomíná Mučednictví člověka Canettiho Masu a moc, což není nízko nastavená latłka. ${ }^{355}$

354 Reade 1910, 504-505.

355 Budil 2015, 858-861. 


\section{Literatura}

Budil, Ivo 2013: Úsvit rasismu, Praha.

Budil, Ivo 2015: Triumf rasismu, Praha.

Doyle, Arthur Conan 2013, Podpis čtyř, Praha.

Pakenham, Thomas 1991: The Scramble for Africa, London.

Reade, William Winwood 1860: Liberty Hall, Oxon, London.

Reade, William Winwood 1861: The Veil of Isis or Mysteries of the Druids, London.

Reade, William Winwood 1864: Savage Africa, London.

Reade, William Winwood 1873: African Sketch Book, London.

Reade, William Winwood 1874: The Story of the Ashanti Campaign, London.

Reade, William Winwood 1875: The Outcast, London.

Reade, William Winwood 1910: The Martyrdom of Man, London. 


\section{Vladimír Liščák}

\section{První novověcí misionáři v č́íně (16. století)}

\section{Úvodem}

V důsledku námořní expanze Portugalska a Španělska ve druhé polovině 15. století došlo mezi oběma velmocemi ke sporům o nová území. Smlouvou z kastilského Tordesillas (španělsky Tratado de Tordesillas, portugalsky Tratado de Tordesilhas) ze 7. června 1494, podepsanou fakticky na popud Alexandra VI. z valencijského rodu Borjü (latinsky Alexander PP. VI, španělsky Alejandro VI, italsky Alessandro VI, vlastním jménem Roderic Llançol i de Borja, též Roderic de Borja, španělsky Rodrigo de Borja, italsky Rodrigo Borgia, 1431-1503, papež v Římě 1492-1503), byl svět nakonec rozdělen na španělskou (západní) a portugalskou (východní) oblast vlivu. ${ }^{356}$

Mezi Svatým stolcem a panovníky Španělska a Portugalska byla uzav̌̌ena řada smluv, jež na oba krále delegovaly církevní správu a misionářskou činnost na jejich územích. Španělské právo královského patronátu (španělsky patronato regio) bylo schváleno Juliem II. (latinsky Iulius PP. II, italsky Giulio II, vlastním jménem Giuliano della Rovere, 1443-1513, papež v Římě 1503-1513) roku 1508, jeho portugalskou obdobu (portugalsky padroado real) potvrdil jeho nástupce Lev X. (latinsky Leo PP. $X$, italsky Leone $X$, vlastním jménem Giovanni di Lorenzo de' Medici, 1475-1521, papež v Římě 1513-1521) roku 1514. ${ }^{357}$ Toto právo

356 Zwettler 1995.

357 Lach 1965, 230-245. 
zahrnovalo schvalování a zřizování katedrál, kostelů, klášterů apod. v rámci sfér královských patronátů.

Již od poloviny 16. století do Číny sice přicházeli zejména portugalští jesuité, avšak vzhledem k malému počtu obyvatel Portugalska ${ }^{358}$ musela portugalská vláda brzy využívat misionáře jiných národností. Př́slušníci jesuitského řádu z jiných zemí však byli nuceni vstoupit do portugalských služeb. Na Východ tak vyplouvali přes Portugalsko a museli mít portugalský pas. ${ }^{359}$ Portugalsko nicméně brzy nebylo schopno řešit nedostatek kněží v misiích, a to jak z vlastních sil, tak pomocí jesuitů z jiných zemí. Jednou z možností bylo začít vysílat do Číny kněží ze španělsky mluvících mendikantských řádů (dominikáni, františkáni a augustiniáni), tedy pod patronací španělského patronata, a to i proti vưli Portugalců. ${ }^{360}$

Systém španělského královského patronátu využívali zejména španělští františkáni, dominikáni a augustiniáni, působící v Novém světě a v některých zemích obsazených Španělskem, především na Filipínách a Tchaj-wanu. Tím však de facto porušovali smlouvu z Tordesillas.

Rozdělení světa mezi Španělsko a Portugalsko vysvětluje, proč až do konce 17. století existovaly dvě oficiální trasy z Evropy do Číny. Kratší trasa zahrnovala získání víza a lodního lístku mimo Lisabon, přímo na portugalské lodi, která plula kolem jižního mysu Afriky (pozdější mys Dobré naděje) a přistála v př́stavu Góa v Portugalské Indii.Cestovatel pak mohl pokračovat na portugalské lodi do Macaa. Delší trasa zahrnovala odjezd ze Sevilly na španělských lodích směrem na západ. Po přeplutí Atlantiku do Mexika (tehdy Místokrálovství Nové Španělsko, španělsky Virreinato de Nueva España, 1535-1810) bylo nutné přejít Střední Ameriku do Acapulca. Zde se cestovatelé nalodili opět na španělskou lod'a přes Tichý oceán pluli na španělské Filipíny. ${ }^{361}$ Další cesta

358 V polovině 16. století bylo Portugalsko se svými 1,3 milióny obyvatel jedním z nejřidčeji osídlených zemí v Evropě.- Standaert, ed. 2001, 309.

359 Standaert, ed. 2001, 296.

360 Před rokem 1600 španělští dominikáni a františkáni odcházeli přes Mexiko a snažili se doplout do jižní Číny preses Filipíny, a tak obejít portugalské Macao.

361 Tyto španělské lodě, křižující v 16. až počátku 19. století Tichý oceán jednou až dvakrát ročně mezi Manilou (Filipíny) a přístavy Nového Španělska (nyní Mexiko), byly 
z Filipín do Číny byla plná obtǐź, protože Portugalci mohli zatknout každého, kdo se v Macau vylodil bez portugalského víza. Proto se např. španělští františkáni Macau raději vyhýbali a vylodovali se ilegálně na pobřeží provincie Fu-tien v jihovýchodní Číně. ${ }^{362}$

\section{Počátky misionářské činnosti v Číně}

Padesát misionárư různých katolických řádů se v období let 1552 až 1583 pokoušelo proniknout hlouběji do Číny, většinou přes Kanton: dvacet pět jesuitů (z nich sedmnáct kněži), dvacet dva františkáni (jedenáct kněži), dva augustiniáni a jeden dominikán. ${ }^{363}$ Přestože Č́na patřila do oblasti portugalského padroada, pokoušeli se do Číny proniknout i španělští misionárii, kteří jako předmostí využívali tehdy španělské Filipíny. ${ }^{364}$ Nejznámější byly pokusy portugalského dominikána Gaspara da Cruz a navarrského augustiniána Martína de Rada. ${ }^{365}$

Gaspar da Cruz (někdy též španělsky Gaspar de la Cruz; čínským jménem Kche-lu-c'克魯茲Kèlǔzī, ${ }^{*}$ asi 1520, Évora, Portugalsko, † 5. února 1570, Setúbal, Portugalsko ${ }^{366}$ působil v Asii od roku 1548, kdy se spolu s deseti dalšími dominikány vylodil v Portugalské Indii. V letech 1554 až 1556 působil v Malakce a Kambodži. Na konci roku 1556 doplul na Lampacao (čínsky Lang-paj-cao浪白䆙Làngbáizào, Lang-paj-ao浪白澳Làngbái'ào, či Lang-paj-tiao浪白涳Làngbáijiào, kantonsky Long4 baak6gaau3), malý ostrov v deltě Perlové řeky západně od Macaa, který v polovině 16. století hrál významnou úlohu v čínsko-portugalském obchodu. ${ }^{367}$

známy pod obecnými jmény Galeón de Manila, Galeón de Manila-Acapulco, Galeón de Acapulco, či Nao de la China. - Viz např. Sánchez Sanz 2013; Martín-Ramos 2007. 362 Mungello 2009, 37-38.

363 Sebes 1988; Tellechea Idígoras 1993.

364 Křestanskou misi na Filipínách zahájili augustiniáni (1565), následovaní františkány (1577), jesuity (1581) a dominikány (1587). - Standaert, ed. 2001, 295.

365 Ostolaza 2006.

366 Jeden z prvních křestanských misionářủ v Číně a autor pravděpodobně prvního novověkého popisu Číny Tractado em que se cõtam muito por estẽso as cousas da China... - Viz Cruz 1569.

367 Lampacao dnes již neexistuje jako samostatný ostrov, nebot' sedimenty ze 
Během pobytu na Lampacau Cruz obdržel povolení odejít do Kantonu, kde poté asi měsíc kázal ${ }^{368}$ Krátké období významu Lampacaa skončilo kolem roku 1560, kdy se portugalský obchod přesunul na nově založenou základnu v Macau.

Roku 1557 se Cruz vrátil do Malakky a odtud v roce 1560 zamîril do Hormuzu na jihu Persie, kde poskytoval duchovní posilu vojákům portugalské pevnosti. Po třech letech se pravděpodobně vrátil do Indie. Zpět do Portugalska se navrátil roku 1565, v roce 1569 pomáhal obětem moru v Lisabonu. Sám se stal obětí moru začátkem února následujícíno roku po návratu do kláštera v Setúbalu.

Martín de Rada (též Herrada; čínským jménem Ma-ting te La-ta 馬丁.德·拉達Mădīng dé Lādá, též Te La-ta德拉達Dé Lādá, * 30. června 1533, Pamplona, Navarra, † červen 1578, na moři nedaleko Filipín) byl jedním z prvních augustiniánů, kteří evangelizovali Filipíny, a jedním z prvních misionářù, kteří navštívili mingskou Čínu. $\checkmark$ roce 1560 odešel jako dobrovolník do Nového Španělska (Mexiko). V Mexiku bylo de Radovi přiděleno studium jazyka otomi, ${ }^{369}$ kterým začal úspěšně mluvit již po pouhých pěti měsících. Začal dokonce psát instruktážní kázání a knihy v tomto jazyce.

Nadání a administrativních schopností de Rady si všimli nejen představitelé augustiniánů v Mexiku, ale i jeho nadřizení ve Španělsku. $\checkmark$ roce 1565 se zúčastnil expedice na Filipíny, v jejímž čele stál baskický augustiniánský provinciál Miguel López de Legazpi y Gurruchátegui (baskicky Migel Lopez Legazpikoa, též El Adelantado, El Viejo, * asi 1502, Zumarraga, Baskicko, † 20. srpna 1572, Manila, Filipíny). Tato expedice doplula na filipínský ostrov Cebu (cebuánsky Sugbo) 27. dubna 1565. Zde navarrští/baskičtí augustiniáni de Rada, Andrés de Urdaneta y Cerain (* 1498/1508, Ordicia/Ordizia, Baskicko, † 3. června 1568, Mexiko),

systému Perlové řeky způsobily, že se stal součástí většího ostrova. Jméno ostrova je známo v mnoha podobách: Lampacau, Lampacam, Lam Puk, Lanpacan, Lampachan, Lampchào, Lamapacào, Lamapzan, Lanpetan, Lampaço, Lampacao, Lampaçao, Lampacão, Lampação, Langpetsao.

368 Borao 2009, 2-3.

${ }^{369}$ Skupina př́buzných jazyků ve středním Mexiku (endonymum: Hñähñu, Nääho, Näãnho, Ñ'yühü, Hñotho, Hñähü, Hñätho, Yųhų, Yųhmų, Nuųhų, Ñotho, Ñañhu). 
Diego de Herrera († 1576, Filipíny), Pedro de Gamboa a Andrés de Aguirre (* 1527, Baskicko, † 1593, Mexiko) zahájili první novodobou křestanskou misi ve východní Asii.

De Rada se rychle naučil místní jazyk cebuánštinu (sinugboanon, sinebwano). Na Cebu zůstal až do roku 1572 a v dějinách získal prízvisko „apoštol ǩrestanské víry na Cebu“. V roce 1572 se stal augustiniánským regionálním superiorem ${ }^{370}$ na Filipínách. Ještě na Cebu začal studovat čínský jazyk, takže roku 1574 působil jako tlumočník skupině čínských obchodníků, kteří navštívili Manilu. Dne 26. června 1575 de Rada a mexický augustinián Jerónimo Marín (čínským jménem Ma Lin馬 林Mă Lín, † 1606, Mexiko) doprovázeli delegaci ứedníkủ do Číny. Do př́stavu Sia-men (廈門Xiàmén, historicky Amoy, jihofutiensky E-mn̂g) v provincii Fu-tien (španělsky provinçia de Hocquien) dospěli 5. července a navštívili řadu měst. ${ }^{311}$ Skupina se vrátila do Manily dne 28. řijna 1575. Po svém návratu de Rada sepsal podrobné postřehy o Číñanech a jejich způsobu života. ${ }^{372}$ Tento popis později velkou měrou pomohl k uskutečnění františkánské mise.

Mezitím byla dne 7. března 1575 oficiálně založena augustiniánská Provincie Nejsvětějšího Jména Ježǐš na Filipínách (španělsky Provincia del Santísimo Nombre de Jesús de Filipinas). Na její prípravě se po roce 1565 účastnil i de Rada. V roce 1578 byl vyslán guvernérem Manily na Borneo, kde měl urovnat spor v sultánově rodině. Expedice však nebyla úspěšná a de Rada na zpáteční cestě onemocněl a krátce před přistáním v Manile zemřel.

\section{Portugalští a španělští jesuité v Číně v 16. století}

Mezi prvními jesuity na území Č́ny byl Melchior Núnes Barreto (čínským jménem Pa Laj-tuo巴萊多Bā Láiduō, ${ }^{*}$ asi 1520, Porto, Portugalsko, † 10. srpna 1571, Góa, Portugalská Indie). Do jesuitského

\footnotetext{
370 Superior, představený, je označení řeholního představeného v řeholním institutu, ve společnosti apoštolského života, nebo i obecné označení představeného v katolické církvi.

371 Boxer - Pereira - Cruz - Rada 1953.

372 Relaçion Verdadera delascosas del Reyno de TAIBIN ... - Viz Rada 1575.
} 
řádu vstoupil v Coimbře v březnu 1543. V roce 1551 odešel do tehdy portugalské Indie, kde ho sv. František Xaverský (1506-1552) jmenoval rektorem koleje v Baçaimu (dnešní Vasai, severně od Bombaje). Po smrti Františka Xaverského se roku 1553 stal provinciálem Indie a roku 1554 odešel do Č́ńny.

Jako první evropský misionář navštívil jihočínský Kanton, a to dvakrát (v červenci a srpnu 1555), aby osvobodil jistého Portugalce Matea de Brito, který tam trávil šest let ve vězení; v obou prípadech musel Núnes po měsíci odejít. Potřetí přišel do Kantonu během postu před Velikonocemi roku 1556 a poté pokračoval do Japonska. V červnu 1556 se prípojil k portugalské misii v tehdejší japonské provincii Bungo (japonsky 豊後国 Bungo no kuni) na východě ostrova Kjúšú. Následujícího roku (1557) se vrátil do Indie, kde se stal rektorem jesuitské koleje v Kóčínu. ${ }^{373}$

Jedním z prvních jesuitských misionářů na Dálném východě a spolupracovníkem sv. Františka Xaverského, průkopníka této mise, byl Balthasar Gago (portugalsky Baltezar Gago, * asi 1515/1520, Lisabon, Portugalsko, † 1583, Góa, Portugalská Indie). Do jesuitského řádu vstoupil v roce 1546 v Lisabonu. 17. března téhož roku vyplul na lodi São Pedro na východ. Svou misionářskou kariéru začal v Góji a roku 1550 založil jesuitskou rezidenci v jihoindickém Kóčínu.

V roce 1552 doprovázel Františka Xaverského a některé další jesuity na východ, v Malakce se však rozdělili: František odešel do Číny a Balthasar směroval do Japonska, kam dorazil roku 1555. Působil v provincii Bungo a v Hiradu (平戸市 Hirado-shi) v prefektuře Nagasaki založil katolickou komunu, která čítala 500 členů. Mezi konvertity byli i príslušníci vysoké šlechty (japonsky daimjó大 名 daimyō; doslova "velké jméno").

Z Japonska odplul roku 1560 na ostrov Chaj-nan (čínsky Chaj-nan-tao 海南島 Hăinándăo) v Jihočínském moři, kde pobyl několik měsíců (listopad 1560 až květen 1561). Krátce pobyl také v Macau (do 1. ledna 1562), kde se jesuité snažili vybudovat základnu pro mise v Japonsku

${ }^{373}$ Borao 2009. 
a Číně. V té době bylo v Macau na 500 až 600 Portugalců. Z Macaa odešel přes Malakku do Góy, kde působil až do své smrti. ${ }^{374}$

K prvním španělským jesuitům a spolupracovníkům sv. Františka Xaverského ve východní Asii patřil Francisco Pérez (též Peres, Pirez apod.; čínským jménem Pchej Laj-s'培萊思Péi Láisī, * 1514, Villanueva de Barcarrota, Extremadura, Španělsko, † 22. února 1583, Negapatam/Nākappațtinam, Indie). Do jesuitského rádu vstoupil 25. ledna 1544 v Coimbře v Portugalsku. Dne 8. dubna 1546 vyplul na lodi Flor de la Mar a jeho první zastávkou byla - jak bylo v té době obvyklé - Góa v Portugalské Indii. Poté pokračoval do Malakky, kde roku 1548 založil jesuitskou rezidenci. V roce 1552 byl jmenován superiorem indické misie.

V dubnu 1562 odplul do Kantonu a 28. srpna (či července?) 375 následujícího roku (1563) vstoupil do Macaa (in Sinis) s poselstvem portugalského krále, vedeným Diogem (Diegem) Pereirou (1563-1565 capitão-mor de Macaul) ${ }^{376}$.

V Macau Pérez spolu s Andrém Pintem a Manuelem Teixeirou založil roku 1565 jesuitskou rezidenci (od roku 1594 Kolej svatého Pavla, portugalsky Colégio de São Paulo, též Kolej Matky Boží, portugalsky Colégio da Madre de Deus) a do prosince 1565 byl jejím prvním ředitelem. Dne 21. listopadu 1565 navštívil opět Kanton, aby předložil čínským hodnostárưm dvě memoranda psaná portugalsky a čínsky, v nichž vysvětloval, kdo je a žádal o povolení usadit se v Číně. Hodnostári jeho žádost odmítli s tím, že pro cizince platí absolutní zákaz trvale pobývat v Číně. V roce 1568 Pérez odešel zpět do Góy.

André Pinto (čínským jménem Pching Tchuo平托Píng Tuō, * asi 1538, Porto, Portugalsko, † 1588, Macao) vstoupil do jesuitského rádu v Góji v květnu 1557. Na východní misi odjel přes Malakku (1562) a 28. srpna (či července?) 1563 priplul do Macaa spolu s Franciskem Pérezem a Manuelem Teixeirou v poselstvu Dioga Pereiry. Na konci

\footnotetext{
374 Cieslik 1954; Dehergne 1940.

375 Jednotlivé prameny se v tomto datu neshodují.

${ }^{376}$ Capitães-mores (doslova: kapitáni-majoři) byli první zástupci Portugalska v Macau (v letech 1557-1623), ještě před zavedením funkce guvernéra Macaa.
} 
listopadu 1564 vykonal krátkou návštěvu Kantonu. V roce 1569 se vrátil do Góy a roku 1577 odešel na misi do Japonska, později ho opět nacházíme v Macau. V roce 1581 doprovázel italského jesuitu Michela Ruggieriho (1543-1607) během jeho krátké návštěvy Kantonu. Roku 1584 byl v Macau jmenován jesuitským prokurátorem pro mise v Indii a Japonsku.

Manuel Teixeira (též Emmanuel Texeira, Teixeyra, Tesceira, Texeyra; čínským jménem Tchaj Ma-nuo泰瑪諾 Tài Mănuò, * 1536, Miranda do Doiro, Portugalsko, † 19. března 1590, Góa, Portugalská Indie) opustil Portugalsko 10. března 1551 a v záŕí téhož roku připlul do Góy. Na počátku roku 1552 se zde setkal se sv. Františkem Xaverským, který se chystal na svou cestu na východ. Na východní misi odjel Teixeira přes Malakku (1562) a 28. srpna (či července?) 1563 připlul do Macaa spolu s Franciskem Pérezem a Andrém Pintem ve vyslanecké misi Dioga Pereiry. Na konci ledna 1564 odešel spolu s Balthasarem da Costa na ostrov Ilha do Pinhal, později známý jako Lantau (dnes čínsky Ta-jü-šan大嶼山 Dàyǔshān) ${ }^{377}$, nedaleko Macaa (dnes součást Hongkongu). Otec Teixeira se také dvakrát účastnil obchodní mise do Kantonu (18. listopadu až 1. prosince 1564 a 21. listopadu až začátek prosince 1565).

V roce 1565 spolu s Franciskem Pérezem založil v Macau jesuitskou rezidenci, později Kolej svatého Pavla při katedrále Matky Boží. Ve stejném roce byl Teixeira spoluzakladatelem jesuitské katedrály svatého Pavla (portugalsky Igreja de São Paulo, později přejmenované na katedrálu Matky Boží, Igreja da Madre de Deus). V roce 1835 katedrála vyhořela a dochovalo se pouze její prǔčelí, které patří k nejvýznamnějším památkám Macaa. ${ }^{378}$

377 Jeho evropské jméno je odvozeno od nejvyšší hory na ostrově, Lantau Peak (též Fung Wong Shan, čínsky Feng-chuang-šan鳳凰山 Fènghuáng Shān, doslova „Hora fénixü", též Lan-tchou-šan爛頭山 Làntóu Shān), 934 m n. m. Ta má dva vrcholky: Feng-šan 鳳山 Fèng Shān, Hora mužského fénixe, a Chuang-šan 凰山 Huáng Shān, Hora ženského fénixe.

${ }^{378}$ Ruínas de São Paulo (čínsky Ta-san-pa pchaj-fang大三巴牌坊Dàsānbā Páifāng) jsou součástí památek UNESCO v historickém centru Macaa od roku 2005. 
V roce 1568 se otec Teixeira vrátil do Góy. V letech 1569-1572 byl rektorem jesuitů v Kóčínu a 1573-1574 viceprovinciálem pro Indii. ${ }^{379}$

Prvním jesuitským biskupem v Číně, respektive v Macau, byl Melchior Miguel Carneiro Leitão (též Melchior Nunes Carneiro Leitão; čínským jménem Ťia Naj-lao賈耐勞 Jiă Nàiláo, též Ťia Naj-luo加奈 羅 Jiā Nàiluō, v Macau uváděný pod jmény Belchior Miguel Carneiro Leitão a Ťia Ni-lao賈尼勞 Jiă Níláo, * 1516, Coimbra, Portugalsko, † 19. srpna 1583, Macao). Do jesuitského řádu vstoupil 14. března 1543 v Coimbře a 25. dubna byl vysvěcen na kněze. V roce 1551 byl jmenován prvním rektorem jesuitské koleje v Évoře (portugalsky Colégio do Espírito Santo), pozdější slavné univerzity. 23. ledna 1555 byl jmenován titulárním biskupem ${ }^{380}$ v Níkaji (latinsky episcopus titularis Nicænus|381 ve funkci pomocného biskupa nově jmenovaného etiopského patriarchy. Protože však brzy nato odjel do Góy, nemohl být vysvěcen v Portugalsku (vysvěcen byl nakonec až 15. prosince 1560).

$\checkmark$ breve ${ }^{382}$ Ex Litteris carissimis z 2. února 1566 byl Piem V. (latinsky Pius PP. V, italsky Pio V, vlastním jménem Antonio [Michele] Ghislieri, 1504-1572, papež v Římě 1566-1572) jmenován apoštolským administrátorem ${ }^{383}$ pro portugalské misie $v$ Japonsku a Číně. Až do roku 1567 však pokračoval v misionářské činnosti na Malabárském pobřeží

379 Braga 1949; Wicki 1952.

380 Titulární biskup (latinsky episcopus titularis; čínsky ling-sien Ču-tiao領銜主 教lǐngxián zhǔjiào), „biskup v krajích nevěřících“ (latinsky episcopus in partibus infidelium), biskup, který nespravuje skutečnou diecézi, ale diecézi zpravidla již zaniklou.

${ }^{381}$ Níkaja (řecky Níkaı a latinsky Nicæa) je historické město v severozápadní Anatolii, na území dávné Bithýnie, v dnešním Turecku, které je známo především jako místo konání dvou ekumenických koncilů starověké křest’anské církve. Současné moderní město se jmenuje İznik.

${ }^{382}$ Breve (z latinského brevis, „krátký”) je krátký list, kterým papež předkládá stanovisko k určitému problému. Stejně jako papežská bula se obvykle označuje prvními slovy textu.

${ }_{383}$ Apoštolský administrátor (latinsky administrator apostolicus, čínsky cung-cuo šu-li宗座署理zōngzuò shǔlī) je prelát (může to být kněz nebo biskup) ustanovený papežem, aby jako ordinář vykonával správu nad apoštolskou administraturou, nad diecézí, která nemá biskupa, nebo (výjimečně) nad diecézí, jejíž biskup nemůže správu vykonávat. 
v Portugalské Indii. Tehdy byl pozván, aby prišel do Macaa, kde jesuité zř́dili misii.

Do Macaa připlul v červnu 1567, a stal se tak prvním vysvěceným biskupem v oblasti Číny a Japonska. V roce 1569 založil Nemocnici pro chudé (portugalsky Hospital dos Pobres; pozdější Nemocnice svatého Rafaela, Hospital de São Rafael) a Svatý dům milosrdenství (portugalsky Santa Casa da Misericórdia), první evropskou charitativní organizaci v Macau. ${ }^{384}$ Kromě toho založil nedaleko katedrály sv. Pavla i leprosárium pro péči o malomocné (čínsky ma-feng ping-jüan麻風病院

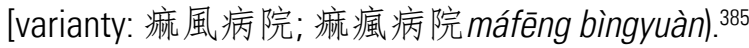

Jeho dílo bylo završeno, když papež Řehoř XIII. (latinsky Gregorius PP. XIII, italsky Gregorio XIII, vlastním jménem Ugo Buoncompagni, 1502-1585, papež v Římě 1572-1585) zrídil bulou Super Specula Militantis Ecclesiæ z 23. ledna 1576 Macaoskou diecézi. Prvním papežským kandidátem na biskupa Macaa nebyl však Carneiro, ale Diogo Nunes de Figueira (latinsky Didacus Nunnez Figueira). Ten nicméně jmenování odmítl a nikdy do Macaa nepřijel. Druhým kandidátem byl Leonardo Fernandes de Sá († 1597), sekulární kněz z Kristova řádu, ${ }^{386}$ který byl potvrzen biskupem Macaa 22. ledna 1578. Do Macaa však připlul až v roce 1581.

Do té doby Carneiro tedy sloužil jako administrátor nové diecéze (1576 až 1581). Přestože nebyl oficiálně jmenován biskupem Macaa, je považován za prvního biskupa v Číně a Japonsku. V roce 1577 byl Carneiro jmenován nominálním patriarchou Etiopie (latinsky Patriarcha AEthiopiensis, 1577-1581), ačkoli sám tam nemohl odcestovat. ${ }^{387}$

\footnotetext{
384 Teixeira 1970.

385 Standaert, ed. 2001, 793.
}

386 Kristův řád (plným názvem Řád rytîrů našeho Pána Ježíše Krista, portugalsky Ordem dos Cavaleiros de Nosso Senhor Jesus Cristol byl původem portugalský rytîrský rád založený v souvislosti se zánikem templářů králem Dinisem I. (portugalsky Dinis I de Portugal, 1261-1325, vládl 1279-1325) asi v roce 1317 či 1318 a potvrzený bulou Ad ea ex quibus Jana XXII. (latinsky loannes PP. XXII, francouzsky Jean XXII, vlastním jménem Jacques Duèze, Jacques Duèse nebo d'Euze, 1249-1334, papež v Avignonu 1316-1334) ze 14. března 1319. Kristův řád převzal portugalské majetky templářu a snad i část členů tohoto zrušeného řádu.

387 Teixeira 1976, 43-44. 
V srpnu 1568 prìiplul do Macaa Francisco Cabral (* 1528/1529, ostrov São Miguel, Azorské ostrovy, Portugalsko, nebo Guarda, Portugalsko, † 16. dubna 1609, Góa, Portugalská Indie). ${ }^{388}$ Do jesuitského rádu vstoupil v Góji v roce 1554 a působil tam až do roku 1568, kdy odešel na svou východní misi. Nejdřive působil dva roky v Macau (srpen 1568 až červen 1570). Dne 18. června 1570 odešel do Japonska, kde působil jako superior mise až do 8. řijna 1581. Když se Japonsko stalo jesuitskou viceprovincií, stal se jejím prvním viceprovinciálem (1582-1583?).

Poté odešel do Macaa, kde byl v letech 1583 až 1584 rektorem Macaoské koleje (portugalsky reitor do Colégio de Macau) a superiorem čínské mise (latinsky superior Missionis Sinicæ Societatis lesu). Roku 1584 založili jesuité první misii v pevninské Číně v Shiuhingu (též Sauguin, tj. Čao-čching肇慶 | 肇庆Zhàoqìng, provincie Kuang-tung) a Cabral byl jedním z prvních misionářu, kteří zde pưsobili (od 21. listopadu 1584). V prosinci 1586 Macao opustil a odešel znovu do Góy, kde v letech 1592 až 1597 působil jako provinciál Indie (či Indií, jak se tehdy používalo). ${ }^{389}$

Jedním z prvních španělských jesuitů v Číně byl Pedro Riera (též Rieira, Bonaventura, Boaventura, latinsky Petrus de Morales; čínským jménem Li Jie-la黎耶臘Lí Yélà, * asi 1526, Barcelona, Katalánsko, † 1573, v Indickém oceánu při návratu do Evropy). Do jesuitského řádu vstoupil 11. března 1548 v Římě. Dne 25. března 1565 odjel na lodi Esperança do Góy. V srpnu 1567 príjel do Macaa spolu s Juanem Baptistou de Ribera (též Ribeyra; čínským jménem Li Po-la黎伯臘Lí Bólà, ${ }^{*}$ 1525, Xerés (Jerez) de la Frontera, Andalusie, † 23. ř́jna 1594, Plasencia, Extremadura). Diego Laínez Gómez de León (1512-1565), generál jesuitského řádu (1558-1565), jim pred jejich odjezdem z Evropy výslovně doporučil, aby vyvinuli veškeré úsilí pro vstup na území

388 Podle některých pramenů se narodil roku 1528 na ostrově São Miguel (portugalsky I/ha de São Migue/) na Azorských ostrovech, podle jiných roku 1529 v diecézi Guarda (latinsky Diœcesis AEgitaniensis, portugalsky Diocese da Guarda) na severovýchodě Portugalska.

${ }^{389}$ Da Vita e morte do Padre F.C., ms de JA 49-VI-8 ff. 103-111. 
Číny. V říjnu 1568 vstoupili na předměstí Kantonu, kde nejprve žádali magistrátní úředníky o povolení ke vstupu do města, což jim bylo odmítnuto. Otec Ribera se proto rozhodl tam vstoupit tajně, bez vědomí a schválení svých nadřizených. Avšak jeho převozník ho místo toho privezl zpátky do Macaa.

\section{Počátky jesuitské misie a zrod akomodační metody}

Novověké mise na čínské pevnině začaly roku 1582, kdy italští jesuité Michele Ruggieri a Matteo Ricci (latinsky Matthæus Ricci, Mattheus Riccius Maceratensis; čínským jménem Li Mao-tou利瑪竇 Lì Mădòu, * 6. řijna 1552, Macerata, Papežský stát, † 11. května 1610, Peking, Čína), působící v rámci portugalského padroada, získali povolení zř́dit stálou misii v Čao-čchingu (Sauguin) v jižní Číně. Jesuité v době Mattea Ricciho byli první, kdo položili solidní základ pro misie v Čínské řǐši. Postupovali přes provincii Kuang-tung do středočínských provincií a měst, Nankingu, Šanghaje (čínsky Šang-chaj上海Shànghăi), a Chang-čou (杭州 Hángzhōu) a snažili se dojít do Pekingu. Svým breve Ex pastorali officio z 28. ledna $1585^{390}$ dal Řehoř XIII. jesuitům exkluzivní právo šririt evangelium v Japonsku a Číně pod patronátem Portugalské koruny. To jim umožnilo nezávisle rozvíjet svou vlastní misijní metodu.

Pro „jesuitskou misionářskou strategii“" v Číně byla od počátku určující akomodační metoda. Tato strategie byla koncipována Alessandrem Valignanem (též Valignani, latinsky Alexander Valignanus, Valignanius; čínským jménem Fan Li-an范禮安Fàn Lǐ̃ān, zdvořilostní jméno [字zi] Li-šan立山Lishān, * 15. února 1539, Chieti, Neapolské království, † 20. ledna 1606, Macao), někdejším novicmistrem Mattea Ricciho a v letech 1574 až 1606 jesuitským apoštolským vizitátorem (latinsky visitor apostolicus, čínsky cung-cuo š-čcha-jüan宗座視察員 zōngzuò shìcháyuán ${ }^{391}$ pro východní Asii. 392 Jeho strategie byla později kreativně začleněna do praxe Mattea Ricciho. Následující generace

\footnotetext{
390 Text viz Streit - Dindinger - Rommerskirchen - Kowalsky, IV, 1964, 1647.

391 Apoštolský vizitátor je v římskokatolické církvi papežský zástupce s přechodným posláním k provedení kanonické vizitace relativně krátkého trvání. 3920 Valignanovi viz podrobněji např. Collani 1997.
} 
proto až do 18. století spojovaly tuto strategii s Riccim a nazvali ji "Ricciho metoda".

Valignano, který byl ze své dřívější praxe zklamán omezenou mírou inkulturace japonské kultury ze strany jesuitů, trval v Číně především na znalosti čínského jazyka. Proto v roce 1579 povolal několik jesuitů do Macaa a naříil jim zaměřit pozornost výhradně na studium jazyka. 0 dva roky později vstoupil z jihu do Číny Michele Ruggieri a rok nato ho následoval Matteo Ricci. Inspirováni pravděpodobně japonskou situací, oblékali se první jesuité v Číně jako buddhističtí mniši. V roce 1595, po téměř patnácti letech zkušeností, změnili svou politiku a prìzpůsobili se životnímu stylu a etiketě konfuciánské elity literátủ a úředníků. 0 tuto změnu se zasloužil především Matteo Ricci.

Nová politika zůstala nezměněna po celé 17. století a pro většinu jesuitských misionár̊ se prístup Mattea Ricciho stal vzorem akomodační politiky. V roce 1597 ho Valignano jmenoval hlavním jesuitským misionářem pro území Číny. Ricciho způsob akomodace na čínské prostředí a náboženství spočíval - stejně jako u jeho druhủ a pokračovatelů (mezi nimiž bylo v dalších letech i osm př́slušníků české rádové provincie) - především v dokonalém zvládnutí čínštiny, ve znalostech historie čínského národa, jeho světských a duchovních tradic a v navazování dialogu s místními učenci-literáty. Již to byl svým způsobem výrazný ústupek křestanské naď̌azenosti a uznání čínské vzdělanosti.

Matteo Ricci i ostatní jesuitští misionáři - ke značné nelibosti příslušníkủ jiných řeholí působících tehdy v Číně - tvrdili, že přirozená a dávná čínská zbožnost, představy Čiňanů o Bohu atd. vlastně v ǩ̌estanství docházejí pouze svého dovršení, že křestanské učení, at zjevené, či posvěcené tradicí, vede k lepšímu chápání jejich vlastního duchovního dědictví. Všechny prirozené hodnoty čínské kultury měly být tudíz zachovány i v príjatém křestanství. Mezi těmito hodnotami měl své přirozené místo i dávný kult předků a úcta $\mathrm{k}$ filosofovi Konfuciovi. Tento jesuitský prístup kladně oceňovali také čínští císařové jak z dynastie Ming, tak z následující mandžuské dynastie Čching - a to jednak svými tolerančními edikty (napríklad z let 1657 a 1692), jednak celkově príznivým vztahem k cizímu učení a jeho hlasatelům. 
Ricci byl toho názoru, že vynikající etická a sociální doktrína konfuciánství by měla být doplněna o metafyzické myšlenky křestanství. Hájil návrat k původnímu konfuciánství, které považoval za filosofii založenou na přirozeném právu. Podle jeho názoru obsahuje ideu Boha. Nakonec príijal tolerantní postoj k určitým konfuciánským obřadủm, jako uctívání předků a úctu ke Konfuciovi, jež brzy byly označeny za „občanské obřady". Tato politika byla v kontrastu s tou, již prijjaly ostatní tehdejší řády, zejména františkáni a dominikáni. Tyto řády se ukázaly být méně akomodativními, méně orientovanými na vzdělance, méně se zabývajícími vědami a méně tolerantními vưči místním rituálním tradicím. ${ }^{393}$

Jedním z prvních jesuitských misionářũ v Číně byl Michele Ruggieri (též Rogerio, Pompilio Rugiero napolitano, Pompilio de Roggieri, původním jménem Pompilio Ruggieri, latinsky Michael Rogerius; čínskýmjménem Luo Ming-tien羅明堅LuóMíngjiān, zdvořilostníjméno [字 zi] $]^{394}$ Fu-čchu 復初Fùchū, * 1543, Spinazzola, Neapolské království, † 11. května 1607, Salerno, Neapolské království). 395 Pred tím, než vstoupil do jesuitského řádu (v Římě 28. řijna 1572), získal v Neapoli doktorát obojího práva (latinsky in utroque iure), tj. práva civilního a kanonického. Po dokončení obvyklé jesuitské duchovní a intelektuální formace, odjel do Lisabonu, výchozí brány všech misionářù, kteří odcházeli v rámci portugalského patronátu do východní Asie.

Zatímco čekal na lod’ do Góy, byl v březnu 1578 vysvěcen na kněze. Brzy po vysvěcení opustil břehy Evropy a vydal se spolu s dalšími dvanácti misionáŕi do Indie, kam připluli v záŕi 1578. Mezi nimi byli napríklad bl. Rodolfo Aquaviva (též Ridolfo, Rudolfo, * 2. řjijna 1550, Atri, Neapolské království, † 25. července 1583, Cuncolim/Kunikalī u Góy, Portugalská Indie) a Matteo Ricci.

Ruggieri začal okamžitě studovat jeden z jazyků používaných na Malabárském pobřeží a za šest měsíců dosáhl takové dokonalosti, že

\footnotetext{
393 Kolmaš 1999.

394 Zdvořilostní jméno [ $c^{\prime}$ 字zi] je jméno udělované v dospělosti vedle vlastního osobního jména. Tato praxe je tradicí ve východoasijských kulturách, tedy v Číně a Čínou ovlivněných zemích, jako je Japonsko, Korea a Vietnam.

395 O Ruggierim podrobněji viz Collani 1994.
} 
mohl provádět zpověd. ${ }^{396}$ Pravděpodobně toto jeho nadání pro jazyk ho předurčilo pro začátek čínské mise. S několika společníky Ruggieri odplul do Macaa na pobřeží Čínské říše. Přistál v tomto portugalském obchodním centru 20. července 1579 a inned se začal učit čínsky. S vědomím toho, že ho mnozí budou následovat, založil Školu svatého Martina (italsky la casa di San Martino, čínsky Šeng Ma-ting ting-jüan 聖瑪定經院 Shèng Mădìng jīngyuàn, nebo Šeng Ma-er-ting ting-jüan 聖瑪爾定經院Shèng Mă'ěrdìng jīngyuàn), první školu pro výuku čínštiny pro cizince. ${ }^{397}$

0 něco později, 7. srpna 1582, připlul do Macaa i Ricci. V jeho doprovodu byl misionář a malîr Giovanni Niccolò (též Nicolao, Nicolaus, Nicola, Cola, * Nole, Neapolské království, 1560, † 16. března 1626, Macao), který v Macau založil první evropskou malî́skou školu v Asii a o něco později (1603?) podobnou školu založil i během své mise v japonském Nagasaki. Podle jiných údajů odešel z Macaa do Japonska již v roce 1583 a malî̃skou akademii (italsky Seminario dei Pittori) v Nagasaki založil roku 1590.398

Ruggieriho i Ricciho úmyslem však po celou dobu bylo usadit se někde ve „skutečné“ Číně - nikoli pouze v Macau. Ruggieri proto několikrát navštívil Kanton a Čao-čching a navázal užitečné kontakty s místními úřady. Stal se tak jedním z prvních novověkých křestanských misionářů, kteří navštívili pevninskou Čínu. ${ }^{399}$ Po řadě neúspěšných pokusů získat povolení ke zřízení stálé mise v Číně bylo nakonec uděleno v prosinci 1582, a v roce 1583 se Ricci a Ruggieri konečně usadili v Čao-čchingu,

\footnotetext{
396 Malabárské pobřeží v jihozápadní Indii má dlouhou křestanskou tradici. Dosud zde žijí křestané, kteří odvozují svůj původ od prvních indických křestanů, údajně pokřtěných sv. Tomášem. Křestané sv. Tomáše je název pro různé denominace krestanské církve v Indii, zejména na Malabárském pobřeží, uctívající sv. Tomáše. Mezi prvními konvertity byli místní židovští osadníci i původní obyvatelé. - 0 malabárských ǩrestanech existuje bohatá literatura, viz např. Menachery 1973, Menachery 1987, Menachery 1998.

397 Piccinini 2011.

398 Často se reprodukuje jeho údajný portrét daimjóa Ody Nobunagy (織田信長， 1534-1582), který je však datovaný do let 1583-1590, tedy již po Odově smrti. 399 Srv. první návštěvu španělských misionářů v Čao-čchingu v roce 1579.
} 
a to na pozvání tehdejšího prefekta Wang Pchana (王泮Wáng Pàn, životní data neznáme), který slyšel o Ricciho schopnostech matematika a kartografa. Ricci zůstal v Čao-čchingu až do roku 1589, kdy ho nový místokrál z města vykázal.

Právě zde v roce 1584 Ricci sestavil první mapu světa v čínštině v evropském stylu a zahrnující i americký kontinent. Žádný původní výtisk mapy se však nedochoval, dochovalo se pouze šest verzí na rýžovém papíru. Mapa nesčetných zemí světa (čínsky Kchun-jü wan-kuo čchüan-tchu 坤輿萬國全圖 Kūnyú wànguó quántú, italsky Carta Geografica Completa di tutti i Regni del Mondo) byla vytištěna v Pekingu roku $1602 .{ }^{400}$

Během pobytu v Čao-čchingu vydal Ruggieri v roce 1584 v čínštině katechismus (čínsky Tchien-ču šeng-tiao š'-lu《天主聖教實錄》 Tiānzhǔ shèngjiào shílù), první čínskou křestanskou knihu napsanou Evropanem. ${ }^{401}$ V letech 1583 až 1588 vytvořil Ruggieri spolu s Riccim a čínským laikem Sebastiánem Fernándezem (latinsky Sebastianus Fernandez, čínským jménem Čung Pa-siang鐘巴相Zhōng Bāxiāng, též Čung Ming-žen鍾明仁Zhōng Míngrén, psáno též 鍾鳴仁、鍾銘仁， zdvořilostní jméno [字zi] Nien-tiang 念江 Niànjiāng, * 1562, Čína, † 1622, Chang-čou, Čína) portugalsko-čínský slovník (čínsky Pchu-Chan cch'-tien 《葡漢辭典》Pú-Hàn cídiăn), první slovník mezi čínštinou a evropským jazykem, pro nějž také navrhli systém přepisu čínských jmen do latinky. Bohužel se rukopis v jesuitském archivu v Římě ztratil a znovu byl objeven teprve v roce 1934, díky Pasqualu Mariovi d’Elia (čínským jménem Te Li-sien德禮賢 Dé Lǐxián, * 2. dubna 1890, Pietracatella, Itálie, † 18. května 1963, Říma, Itálie), jesuitskému misionáři v Číně, sinologovi a misiologovi. Tento slovník byl nakonec publikován až v roce $2001 .{ }^{402}$

V listopadu 1588 Ruggieri opustil Čínu a odjel do Říma, aby přiměl papeže odeslat poselstvo k čínskému císaři. Účelem bylo umožnit

\footnotetext{
400 D'Elia 1938; Urschel2010.

401 Ruggieri 1584. Faksimile tisku Borg.Cin 324 z Vatikánské knihovny viz <http:// archives.catholic.org.hk/Rare\%20Books/CTJ1/index.htm>. Nahlédnuto 7. 5. 2015. 402 Ruggieri - Ricci; Witek, ed. 2001.
} 
jesuitům dojít do Pekingu a dosáhnout priijetí císařem. Přimět papeže k navázání diplomatických styků s mingskou Čínou se mu však nepodařilo, nakonec se uchýlil do Salerna, kde překládal do latiny konfuciánské spisy, ${ }^{403}$ psal poesii v čínštině a vydával mapy Č́ńny.

Matteo Ricci po odchodu z Čao-čchingu v roce 1589 získal povolení usadit se v Šao-kuanu (韶關 Sháoguān, v Evropě známý jako Xaucheo, Shiuchow, Šao-čou 韶州 Sháozhōu) na severu provincie Kuang-tung. Ve městě zůstal několik let, a protože Šao-kuan ležel na významné severo-jižní trase, podařilo se mu navázat kontakty s projiždějícími hodnostáři, kteří mu umožnili přesunout se na sever, do Nan-čchangu (南昌Nánchāng) v provincii Ťiang-si (čínsky 江西省 Jiāngxī Shěng), Nankingu, a nakonec Pekingu, kam se natrvalo přestěhoval roku 1601.

V Pekingu se Ricci vedle vlastní misijní práce věnoval především rozsáhlé vědecké činnosti v oblasti matematiky, mechaniky, chemie, lékařství, astronomie, geografie a kartografie a v těchto oborech také hojně publikoval, většinou čínsky. Ricci byl vủbec prvním Evropanem, kterému se podařilo dostat se do Zakázaného města. V Pekingu Ricci zůstal až do své smrti roku 1610. Během tohoto pekingského období se mu podařilo přivést ke konverzi řadu tamějších obyvatel včetně některých vysoce postavených úředníkủ. Ricci měl pozoruhodný úspěch v evangelizačním díle pro velkou toleranci, již prokazoval kultu, jímž Číñané uctívali Nebe, Konfucia a předky.

Jednou z charakteristik raného období jesuitské přitomnosti v Číně byla nepř́má propagace za využití evropské vědy a technologie s cílem přilákat pozornost vzdělaných Číñanů a přesvědčit je o vysoké úrovni evropské civilizace. Jesuité nabízeli císaři a dvorským hodnostářùm evropské hodiny, představovali obrazy, které Číñany překvapovaly použitou perspektivou, přeložili matematické spisy Eukleida z Alexandrie ${ }^{404} \mathrm{~s}$ komentáŕi slavného německého jesuitského matematika

${ }^{403} \mathrm{~V}$ roce 1593 vydal preklad části Velkého učení (čínsky Ta-süe 大學Dàxué). - V: Antonii Possevini Societatis lesv Bibliotheca selecta qua agitur de ratione stvdiorum in historia, in disciplinis, in salute omnium procuranda. T. I. Romæ, Ex Typographia Apostolica Vaticana, M. D. XCIII. (1593), lib. IX: 583.

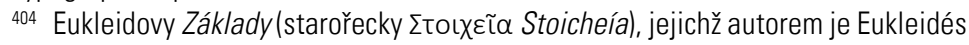


a astronoma Kryštofa Clavia (německy Christoph Clavius, též Christoph Klau, Christopher Klau, Christoph Clau, latinsky Christophorus Clavius, 1538-1612), ${ }^{405}$ pracovali v Astronomickém úřadu (čínsky čchin-tchien-tien欽天監 qīntiānjiān ${ }^{406} v$ Pekingu, psali knihy 0 kalendáři (gregoriánská reforma 1582), ${ }^{407}$ zemědělství, technice, tiskli mapy, které integrovaly výsledky nejnovějších objevů světa.

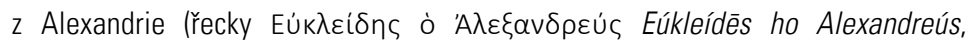
asi 325 př. n. I. - asi 260 př. n. I), byly až do druhé poloviny 19. století po bibli nejvíce rozšrireným dílem světového písemnictví. Jeho dílo nám podává přehled o matematických znalostech Řeků ke konci 4. století př. n. I. Základy jsou učebnicí matematiky, která se skládá z 13 knih. Dnes víme, že pocházejí od několika autorů a jsou založeny zčásti na starších zdrojích.

405 Clavius 1574, Clavius 1589, Clavius1603a.

406 Někdy se překládá jako Matematický úřad.

407 Clavius 1603b. 


\section{Prameny a literatura}

Borao, José Eugenio 2009: „Macao as the non-entry point to China:

The case of the Spanish Dominican missionaries (1587-1632)", in: International Conference on The Role and Status of Macao in the Propagation of Catholicism in the East, Macao, 3-5 November 2009, Centre of Sino-Western Cultural Studies, Istituto Politecnico de Macao. Dostupné z <http://homepage.ntu.edu.tw/ borao/2Profesores/ Maca0\%20Gate.pdfs. Nahlédnuto 7. 5. 2015.

Boxer, Charles Ralph - Pereira, Galeote - Cruz, Gaspar Da - Rada, Martín de 1953: South China in the sixteenth century: being the narratives of Galeote Pereira, Fr. Gaspar da Cruz, O.P. (and) Fr. Martín de Rada, O.E.S.A. (1550-1575), Issue 106 of Works issued by the Hakluyt Society, Printed for the Hakluyt Society (Includes English translations of two of de Rada's reports, with C.R. Boxer's comments). London: Printed for the Hakluyt Society.

Braga, J. M. (José Maria) 1949: The Western pioneers and their discovery of Macao. Macau: Imprensa Nacional.

Cieslik, Hubert 1954: „Baltasar Gago and Japanese Christian Terminology", Missionary Bulletin 8 (Tokyo), 82-90.

Clavius, Christophorus, S.I. 1574: Euclidis Elementorum libri XV, accessit XVI. de solidorum, regularium comparatione omnes perspicuis demonstrationibus accuratis que scholiis illustrati auctore Christophoro Clavio. Romæ: apud Vincentium Accoltum.

Clavius, Christophorus, S.I. 1589: Euclidis Elementorum Libri XV, Accessit XVI. de solidorum regularium cuiuslibet intra quodlibet comparatione, omnes perspicuis demonstrationibus accuratis que scholiis illustrati. Nunc iterumediti ac multarum rerum accessione locupletati. Auctore Christophoro Clavio Bambergensi e Soc. lesu. Romæ: Bartholomæum Grabium.

Clavius, Christophorus, S.I. 1603a: Euclidisposteriores libri IX. Accessit liber XVI. de Solidorum Regularium cuius libet intra quodlibet comparatione. Omnes perspicuis demonstrationibus accuratis que 
scholiis illustrati nunc quarto editi ac multarum rerum accessione post prima meditionem locupletati. Auctore Cph. Clavio Bambergensi e societate lesu. Romæ: apud Aloysium Zannettum, Permissu Superiorum. MDCIII [1603].

Clavius, Christophorus, S.I. 1603b: Romani calendarii a Gregorio XIII. P. M. restitvti explicatio S.D.N. Clementis VIII. P. M. Ivssv edita. Auctore Christophoro Clavio Bambergensi Societatis lesv. Accessit confutatioeorum, qui calendarium aliterinstaurandum esse contenderunt. Romæ, apud Aloysium Zannettum, Ex svperiorvm permissv. cvm privilegio, MDCIII [1603].

Collani, Claudia von 1994: „RUGGIERI, Michele SJ“, in: Traugott Bautz (Hrsg.). Biographisch-Bibliographisches Kirchenlexikon (BBKL). Band VIII, Herzberg, Verlag Traugott Bautz GmbH, 1994: sl. 979-981. Dostupné online za předplatné na: <http://www.bbkl.de/lexikon/ bbkl-artikel.php>. Nahlédnuto 7. 5. 2015; Collani, Claudia von (b.d.). „Biographie von Michele Ruggieri SJ, Chinamissionar". Dostupné online na: <http://stochastikon.no-ip.org:8080/encyclopedia/de/ ruggieriMichele.pdf>. Nahlédnuto 7. 5. 2015.

Collani, Claudia von 1997: „Valignano, Alessandro SJ“, in: Traugott Bautz (Hrsg.). Biographisch-Bibliographisches Kirchenlexikon (BBKL). Band XII, Herzberg, Verlag Traugott Bautz GmbH, 1997: sl. 1092-1096. Dostupné online za predplatné na: <http://www.bbkl.de/lexikon/bbkl-artikel. php>. Nahlédnuto 7. 5. 2015; Collani, Claudia von (b.d.). „Biographie von Alessandro Valignano SJ, Organisator der fernöstlichen Mission". Dostupné online na: <http://stochastikon.no-ip.org:8080/encyclopedia/ de/valignanoAlessandro.pdf>. Nahlédnuto 7. 5. 2015.

Cruz, Gaspar da 1569: Tractado em que se cõtam muito por estẽso as cousas da China, cõsuas particularidades, e assi do reyno dormuz, cõposto por el R. padre frey Gaspar da Cruz da ordẽ de sam Domingos. Dirigido ao muito poderoso Rey dom Sebastiam nosso señor. Impresso com licença. - Na konci je datace: Foy impresso estetratado da China, na muynobre e semprelealcidade de Euora em casa de Andre de Burgos. Acabouse aos 20 dias de Feuereiro de 1570. 
D'Elia, Pasquale M. 1938: I/ mappa mondo cinese del p. Matteo Ricci, S. I. (3. ed., Pechino, 1602) conservato presso la Biblioteca Vaticana. Città del Vaticano: Biblioteca apostolica Vaticana.

Dehergne, Joseph 1940: „Les origines du christianisme dansl' île de Hainan: (XVI'̈me - XVIIèmesiècles)", Monumenta Serica, Vol. 5, No. 1/2, (Pékin, 1940), 329-348.

Kolmaš, Josef 1999: „Akomodace, předchůdce aggiornamenta? Na př́ikladu katolických misií v Číně", Bulletin Jesuité, 8, č. 1, 26-28; č. 2, 26-27; č. 3, 27-28; č. 4, 28-29; č. 5, 25-27.

Lach, Donald F. 1965: Asia in the Making of Europe, vol. 1: The Century of Discovery. Book 1. Chicago and London: The University of Chicago Press.

Martín-Ramos, Clara 2007: „Las Huellas de la Nao de la China en México (La Herencia del Galeón de Manila)“. Dostupné online na: <http://www.scribd.com/doc/13984088/Las-Huellas-de-la-Nao-dela-China>. Nahlédnuto 7. 5. 2015.

Menachery, George, ed. 1973: The Saint Thomas Christian Encyclopedia of India. Trichur: B.N.K. Press.

Menachery, George et al. 1987: Kodungallur: City of Saint Thomas. Azhikode (nakladatel neznámý).

Menachery, George, ed. 1998: The Indian Church History Classics. Vol. I, The Nazranies. Ollur (India).

Mungello, David Emil 2009: The Great Encounter of China and the West, 1500-1800 (Critical Issues in World and International History). 3rd ed. Lanham - Boulder - New York - Toronto - Plymouth, UK: Rowman \& Littlefield Publishers, Inc.

Ostolaza, Ma Isabel 2006: „Fray Martín de Rada, evangelizador, cosmógrafo y embajador en China", Huarte de San Juan. Geografía e Historia $\mathrm{n}^{0}$ 13, 177-198.

Piccinini, Chiara2011: „Shengma'erding Jingyuan (St Martin House / la casa di San Martino) in Macao as the First School of Western Missionaries for Teaching Chinese / 澳門聖瑪爾定經院作 
為西方傳教士們的第一所漢語學校”，in: The Sixth Fu Jen University International Sinological Symposium: "Early European (1552-1814) Acquisition and Research on Chinese Languages" Symposium Papers 輔仁大學第六屆漢學國際研討會: 《西方 早期（1552-1814）漢語學習和研究論文集》. Ed. Zbigniew Wesołowski. New Taibei: Fu Jen Catholic University Printing House.

Rada, Martín de 1575: Relaçion Verdadera de las cosas del Reyno de TAIBIN por otro nombre china y del viaje que aelhizo el muy Reverendo padre fray martin de Rada provinçial que fuede la orden del glorioso Doctor de la yglesia San Agustin. quelovioyanduvo en la provinçia de Hocquien año de 1575 hecha por el mesmo. Bibliothèque Nationale de Paris, Fonds Espagnol, 325.9 (MF 13184), f. 15-30.

Ruggieri, Michele 羅明堅1584:天主聖教實錄|Compendium legis divinæ a P. Michael Ruggiero, S.J.廣東肇慶.

Ruggieri, Michele - Ricci, Matteo; Witek, John W., ed. 2001: Dicionário Português-Chinês, 葡漢辭典 (Pu-Han cidian), Portuguese-Chinese dictionary. Macau - San Francisco: Biblioteca Nacional Portugal, Instituto Português do Oriente, Ricci Institute for Chinese-Western Cultural History.

Sánchez Sanz, Arturo 2013: El Galeón de Manila. La aventura de los tesoros de Oriente. Zaragoza, HRM Ediciones.

Sebes, Joseph 1988: "The Precursors of Ricci”, in: Ronan, Charles. E. - Oh Bonnie C. (eds.): East Meets West. The Jesuits in China, 1582-1773. Chicago: Loyola University Press, 19-61.

Standaert, Nicolas, ed. 2001: Handbook of Christianity in China, vol. I: 635-1800. Leiden - Boston - Köln: Brill.

Streit, Robert - Dindinger, Johannes - Rommerskirchen, Johannes - Kowalsky, Nikolaus 1964: Bibliotheca missionum. Bd. 4. Asiatische Missionsliteratur 1245-1599. 2., unveränd. Aufl. Freiburg: Herder.

Teixeira, Manuel 1970: D. Melchior Carneiro. Fundador da Sta. Casa da Misericordia de Macau. Macau: Tipografía da Missão do Padreado. 
Teixeira, Manuel 1976: „Bispos, Missionários, Igrejas e Escolas: no IV Centenário da Diocese de Macau", (Macau e a sua Diocese, Vol. 12). Macau: Tipografia da Missão do Padroado.

Tellechea Idígoras, José Ignacio 1993: „Expedición franciscana a Cochinchina y China. La relación inédita de Fray Diego de San José (1583)", Archivo Ibero-Americano 53, 449-487.

Urschel, Donna 2010: „Rare 1602 World Map, the First Map in Chinese to Show the Americas, on Display at Library of Congress, Jan. 12 to April 10", Newsfrom the Library of Congress (Washington, D.C.: Library of Congress).

Wicki, José 1952: „As "anotações” do P. Manuel T. a sua "vida do B.P. Francisco Xavier" (1581)", Boletim do Instituto Vasco de Gama, n 69 , Número comemorativo do IV centenário da morte de S. Francisco Xavier, 39-63.

Zwettler, Otto 1995: „Tordesillaská smlouva z roku 1494", Historický obzor, 6, ̌̌. 1. 5-7. 


\section{Tomáš Matějec}

\section{Z minulosti poznávání Blízkého východu v českých zemích: Veleslavínův překlad Itineraria Sacrae Scripturae z roku 1592}

V roce 1592 vyšly z pražské tiskárny Daniela Adama z Veleslavína (1546-1599) tři překladové tituly věnované minulosti biblického světa, které potom po více než dvě století ovlivňovaly pohled českojazyčných čtenářủ na země Blízkého východu. Byly to jednak populární príručka biblického zeměpisu Itinerarium Sacrae Scripturae, to jest Putování svatých na všecku Svatou Biblí obojího Zákona, jejiž původní německé znění pořídil saský evangelický kazatel Heinrich Bünting (1545-1606) a kterou do češtiny přeložil Daniel Adam z Veleslavína sám, dále popis starověkého Jeruzaléma Vypsání města Jeruzaléma i předměstí jeho, přeložený rovněž Veleslavínem z latinské předlohy sepsané holandským katolickým teologem Christianem van Adrichem (1533-1585), a konečně souvislý výklad dějin starozákonního židovského národa Historia židovská na knihy čtyry rozdělená, přeložený z německé předIohy Veleslavínovým spolupracovníkem Václavem Plácelem z Elbinku (1556-1604). Z těchto tří prací v českém prostředí patrně nejvíce působila první, Itinerarium Sacrae Scripturae, - a právě ji chceme připomenout v tomto příspěvku.

Autor Itineraria Heinrich Bünting se narodil v roce 1545 v saském Hannoveru, vystudoval luterskou teologii ve Wittenbergu (magisterského gradu dosáhl roku 1569) a působil pak na několika místech jako evangelický pastor: po krátkých angažmá ve Wittenbergu a na zámku Alt Calenberg je od roku 1575 uváděn jako farář v Gronau a v roce 1591 byl jmenován superintendentem v Goslaru; pro svůj př́klon k nauce 
o ubikvitě byl roku 1599 propuštěn z duchovní služby a poslední léta života strávil jako soukromá osoba v rodném Hannoveru, kde také roku 1606 zemřel. Büntingovu literární činnost, co do počtu vydaných prací nepř́liš velikou, tvoří převážně spisy, které se svým námětem přimykají k Písmu svatému a které Ize pokládat za svého druhu pomůcky k jeho důkladnějšímu studiu. Nejstarší z nich je Itinerarium Sacrae Scripturae, poprvé tištěné roku 1581. Následujícího roku byl jako příloha k druhému vydání Itineraria publikován drobný spisek De monetis et mensuris Sacrae Scripturae, pojednávající o peněžních jednotkách a mírách zmiňovaných v biblických textech. Roku 1589 vydal Bünting v jednom svazku tři další práce: pokus o uspořádání evangelních zpráv o Ježíšově životě do souvislého celku pojmenovaný Harmonia evangelistarum, výklad o životě svatého Jana Křtitele Vita Sancti lohannis Baptistae a rozsáhlé, téměř pětisetstránkové vypsání Ježiššva dětství nazvané Paedia Domini nostri lesu Christi. Zčásti do biblistiky a zčásti do církevních dějin zasahuje další spis, který Bünting vydal v letech 1590-1591 - chronologický přehled světových dějin od stvoření do roku 1591 nazvaný Chronologia, hoc est omnium temporum et annorum series, ex sacris bibliis aliisque fide dignis scriptoribus ab initio mundi ad nostra usque tempora fideliter collecta. Odlišného, ryze dějepisného rázu je spis, který Bünting věnoval minulosti svého rodného kraje, Braunschweigische und Lüneburgische Chronica, tiskem vydaný v letech 1584-1585. S výjimkou Chronologie, která byla vydána latinsky, a latinských pasáží ve spisku De monetis jsou všechny Büntingovy práce psány v národním, vernakulárním jazyce, tj. německy.

Bezpochyby nejúspěšnější z Büntingových spisů bylo Itinerarium Sacrae Scripturae. První vydání vyšlo roku 1581 v Helmstedtu a během deseti let, jež od prvního vydání uplynuly, do roku 1590, vyšlo u různých německých tiskařů deset vydání dalších a ve Stockholmu byl tištěn překlad do švédštiny. Do roku 1600 vyšlo šest dalších německých vydání, překlady do češtiny, nizozemštiny a latiny a znovu byl vydán překlad švédský. V dalším desetiletí, do roku 1610, vyšla čtyři vydání německá, nově se objevil překlad dánský a znovu byly vydány překlad nizozemský a český. Do roku 1620 vyšla další dvě vydání německá, 
znovu byly vydány překlad nizozemský a dánský a nově vyšel překlad anglický. Po roce 1620 už další překlady nepřibývaly, ale i v následujících desetiletích sedmnáctého století se objevují opětovná vydání německá, nizozemská a anglická a ještě i v osmnáctém století, jímž dějiny vydávání Itineraria končí, vyšlo šest vydání německých (poslední roku 1757) a jedno anglické (roku 1705). Během téměř sto osmdesáti let, které uplynuly od prvního vydání v roce 1581 do posledního v roce 1757, tak vyšlo celkem třicet čty̌ri vydání německých, dvanáct nizozemských, sedm anglických a tři dánská a dvakrát byly vydány překlad český, švédský a latinský. ${ }^{408}$

Zájmu tehdejších čtenár̆u Itinerarium zřejmě vycházelo vstříc zejména tím, že vnášelo jistý pořádek do zeměpisných údajů uváděných v Písmu a přiměřeně a prístupným způsobem zpravovalo o místech, jejichž jména byla čtenářum z biblických nebo jiných duchovních textů známá nebo alespoň povědomá. 0 místech spojených s biblickými ději se tehdejší čtenáři vládnoucí vernakulárními jazyky namnoze dovídali také z rozmanitých cestopisư, nicméně Itinerarium nad ně patrně vynikalo přehledným, systematickým usporádáním látky a nad některé z nich snad i jistou uměřeností, pokud jde o dávkování informací poskytovaných čtenářum, ani neodrazujíc př́lišnou stručností a úsečností, ani neunavujíc préebytkem podrobností.

Hlavní část textu Itineraria je složena z nevelkých dílčích pojednání věnovaných vždy jedné biblické postavě, jakýchsi „personálních hesel“. Ta jsou seřazena v zásadě chronologicky, takže v prvním dílu se postupně probírají postavy Starého zákona a v druhém dílu postavy zákona Nového. Pozornost se přitom soustředuje především na významné postavy, jako jsou např. Abraham, Izák, Jákob, Josef Egyptský, Mojžišs, Samuel, David, Šalomoun, Eliáš, Izaiáš, Jeremiáš, Daniel, z novozákonních např. Ježíš Kristus, Panna Maria, sv. Jan Křtitel, sv. Petr, sv. Jan, sv. Pavel, nicméně zejména ve starozákonní části mají své vlastní „hesIo" i četné postavy spíše epizodní, např. soudce Jiftách (Sd 11,1-12,7) nebo Saulův vojevůdce Abner (1 Sam 26,5.7.14-15 aj.). Zařazeny jsou také postavy pojímané v biblickém textu více či méně negativně,

${ }^{408}$ Souhrnný přehled známých vydání podává Heijden 2001, 13. 
např. Gedeonův syn Abimelech (Sd 8,31-9,57) nebo babylonský král Nabuchodonosor. Některá hesla jsou věnována kolektivním postavám, např. andělům, kteří vyvedli Lota ze Sodomy (Gn 19, 1-23), nebo zvědům, kteří byli kmenem Dan vysláni do zaslíbené země (Sd 18,2-8). Svá hesla mají i postavy z deuterokanonických knih, např. Judit, Tobiáš nebo Juda Makabejský.

Typická struktura "hesla” je následující: V čele stojí nadpis, který uvádí jméno postavy, jíž je výklad věnován. Pak je uveden stručný výčet cest, které Písmo dané postavě připisuje, doplněný odhadem vzdáleností, jež postava na těchto cestách urazila, a jejich celkovým součtem. Následují výklady o místech, které postava na těchto cestách navštívila. Tyto výklady bývají podle potřeby různě rozsáhlé, od několika řádků po několik stránek. Nezř́́dka se neomezují na popis dané lokality v tom stavu, v jakém byla v době, kdy ji daná postava navštívila, ale připomínají také dřivější nebo pozdější významné mimobiblické události, které jsou s daným místem spojeny, poprípadě naznačuji proměny, jimiž místo prošlo v pobiblických dobách, nebo na základě cestopisů popisují jeho novodobý stav. Pravidelně se ve výkladech připomínají další biblické děje, které se $v$ dané lokalitě odehrály. $V$ některých heslech, zvláště pokud jsou věnovány významnějším starozákonním postavám, např. Jákobovi, Josefovi Egyptskému, Samsonovi nebo králi Davidovi, bývá navíc připojen závěrečný duchovně naučný oddíl věnovaný „alegorii", 409 totiž výkladu o tom, v jakém smyslu ta která starozákonní postava představuje prefiguraci, typus, předobraz Ježíše Krista.

Jako príklad Ize uvést "heslo" věnované patriarchovi Abrahámovi. Nadepsáno je „Cesty Abrahámovy". ${ }^{410}$ Nejprve je v něm podán výčet cest, které Abrahám podnikl: ze své vlasti, z Uru Chaldejského, vyšel podle 11. kapitoly knihy Genesis do Charanu v Mezopotámii a na této cestě urazil osmdesát čtyři německé míle; z Charanu pak šel na Boží

\footnotetext{
409 „.... die Allegoria oder Geistliche Bedeutung...” (Bünting 1587, 3.) Ve Veleslavínově českém překladu: „... dotkne se také Allegoriae, o duchovním výkladu některých věcí..." (Bünting 1592, 7.)

410 „Abrahams Reisen.” (Bünting 1587, 74.) Ve Veleslavínově překladu: „Cesty S. patriarchy Abraháma." (Bünting 1592, 99.)
} 
rozkaz do Šekemu a na této cestě urazil sto německých mil; ze Šekemu odešel na horu mezi Betelem a Hajem a tato cesta byla dlouhá sedm mil; z hory mezi Betelem a Hajem táhl na jih až do Egypta a na této cestě urazil šedesát mil atd. - takto se postupně vypočítávají všechny Abrahámovy cesty až do jeho poslední cesty do Hebronu, kde podle 23. a 25. kapitoly knihy Genesis trávil svá poslední léta a zemřel. K tomuto přehledu cest je připojen souhrnný údaj („Summa“), podle něhož byla celková délka všech Abrahamových cest 449 německých mil.

Následuje výklad o jednotlivých místech. Krátce se pojednává o Uru Chaldejském: jeho název se spojuje s hebrejským 'or, "světlo"; podle „učencư" ${ }^{411}$ prý v Uru Chaldejském pohané uctívali oheň (světlo); tato modloslužba byla prý také príčinou, proč Abraham z města odešel. Následuje výklad o Charanu. Připomíná se, že Charan v pozděǰších dobách náležel k parthské říši a že měl svưj význam pro rímské dějiny: $\checkmark$ bitvě, kterou u něho v roce 53 před Kristem svedli Parthové a Římané, padl „bohatý Ǩíman“ Crassus. ${ }^{412}$ Crassova smrt je popsána v duchu starověkého podání, doloženého u Diona Cassia - Parthové ho zajali a usmrtili tak, že mu do hrdla nalili roztavené zlato. ${ }^{413}$ Dále se príipomíná, že později patřil Charan Peršanům a v současné době že leží na území ovládaném Turky. Na základě cestopisných zpráv Bünting popisuje zeměpisnou polohu a nynější podobu města: jeho př́ijemný vzhled, značnou velikost, opevnění, zmiňuje také výrobu „krásných barevných koberců”, které se "někdy dovážejí i k nám", ${ }^{114}$ a velké skladiště zboží,

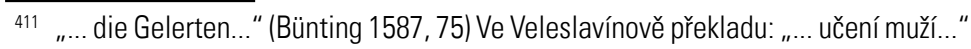
(Bünting 1592, 100)

412 „.... der reiche Römer...” (Bünting 1587, 75 a 76) Ve Veleslavínově překladu: „... onen bohatý Římanín...” (Bünting 1592, 101), resp. „... onen znamenitě bohatý Ř́manín" (tamt.)

413 „.... vnd die Parthen haben inm zerschmoltzen Goldt in den Hals gegossen / vnd gesagt / sauff nu Gold / da dir Geitzhals immer nach gedürstet hat / damit du dermal eins deinen geitzen Rachen voll kriegest." (Bünting 1587, 76) Ve Veleslavínově překladu: „A Parthové nalili mu do hrdla rozpuštěného horkého zlata, řkouce: Pí a žer zlato, kteréhožs ničemný lakomče žíznil, aby jím aspoň jednou své lakomé hrdlo naplnil." (Bünting 1592, 101)

${ }^{414}$ „Es gibt alda zimliche grosse hantierung / insonderheit mit schönen geferbten Teppichen / die daselbst gemacht / vnd bißweilen auch wol zu vns heraus gebracht 
které do města přivážejí karavany. Při té príležitosti Bünting čtenáři vysvětluje, co slovo karavana znamená: „Jsou pak karavany veliké houfy velbloudů, koní a zvir̃at, které nesou náklad a při nichž jsou lidé, kteří táhnou světem za obchodem." ${ }^{415}$ Zvláštní pozornost věnuje Bünting studně, která se prý pobliž Charanu ukazuje a u níz prý se Rebeka setkala s Abrahámovým služebníkem Eleazarem (Gn 24,15-28) a později také Ráchel s Jákobem (Gn 29,9-12). Následuje výklad o samařském městě Šekemu, přičemž je zvláště připomínána úloha, kterou Šekem hraje v jiných starozákonních textech: je tam situován príběh o znásilnění Jákobovy dcery Diny (Gn 34, 1-31), byly v něm pohřbeny kosti patriarchy Josefa (Joz 24,32), soudce Abimelech město zničil a jeho území nechal posypat solí (Sd 9,45), izraelský král Jeroboám je nechal znovu vystavět a bydlel v něm (1 Král 12,25), u Šekemu byla studna, u níz se Ježíš setkal se Samaritánkou (Jan 4,5-26).

Další výklady jsou věnovány egyptskému městu Tanis, hoře mezi Betelem a Hajem, na kterou Abrahám vystoupil, místu, které Bünting označuje jako Hain More (Gn 12,6), a zvláště městu Hebronu, dále městům Gerar a Beršeba a hoře Moria. V závěru je připojeno ponaučení 0 "duchovním významu" patriarchy Abraháma. ${ }^{416}$

Podobným způsobem jsou pak uspořádány i další výklady o starozákonních i novozákonních postavách. Uvedená struktura pritom bývá důsledněji zachovávána v „heslech“ rozsáhlejších, zatímco v heslech kratších bývá častěji více či méně zjednodušována.

werden.” (Bünting 1587, 75) Ve Veleslavínově překladu: „Dosti tam veliký handl, zvláště na pěkné barevné čalouny a koberce, kteřǐz se v tom městě dělaji / a někdy i k nám také do těchto zemí dostávají a přinášejí." (Bünting 1592, 101)

415 "Es sind aber Carouauen grosse hauffen Cameel Pferde vnd Thier / die Last tragen / dabey viel Leute sind / die irer Kauffenschaffe nach / durch die Lande ziehen." (Bünting 1587, 76) Ve Veleslavínově překladu: „Jsou pak karovaví (!) velicí houfové mezkưv a velbloudưv, kteřǐz těžké náklady nosí / při nichž také množství lidí jest, kteřǐz po svém kupectví skrze zemi a přes svět pracuji.." (Bünting 1592, 101)

416 "Geistliche bedeutung des heiligen Patriarchen Abraham." (Bünting 1587, 79) Ve Veleslavínově překladu: „Duchovní vyznamenání svatého patriarchy Abraháma.” (Bünting 1592, 106) 
K hlavnímu výkladu sestavenému z „personálních hesel“ jsou prípojena čtyři relativně samostatná pojednání: výklad o délkových mírách, ${ }^{417}$ obšírný popis starověkého i soudobého Jeruzaléma, ${ }^{418}$ výklad o rozdělení kananejské země mezi izraelské kmeny ${ }^{419}$ a již zmiňovaný spisek o penězích a mírách v biblických textech. ${ }^{420}$ Výkladüm prvního dílu Itineraria je dále předřazen seznam užitých pramenů, dedikace, předmluva evangelického teologa Martina Chemnitze, dvě latinské oslavné básně a autorova předmluva. Důležitou složkou Büntingova spisu byly mapy: z nich trvalou pozornost odborníků i širší veřejnosti pritahuje zejména trojice alegorických map - mapa světa v podobě jetelového trojlístku (který byl erbovním znamením Büntingova rodiště Hannoveru), mapa Evropy v podobě panny, resp. královny a mapa Asie v podobě okř́dleného koně. Zařazeny však byly také reálněji provedené mapy zachycujicí svět, Afriku a zemi kananejskou ve skutečných proporcích. Připojena byla dále mapa zobrazující cestu Izraelitů z Egypta do zaslíbené země, mapa znázorňující cesty apoštola Pavla, plán starověkého Jeruzaléma a vyobrazení ideální podoby jeruzalémského chrámu. ${ }^{421}$

V závislosti na širokém spektru lokalit, které bibličtí autoři ve svých textech zachycují, poskytovala Büntingova kniha raněnovověkému

417 „Eine kurze Unterrichtung / wie man die Geometrische abmessung recht verstehen sol.“ ( Bünting 1587, 31-35) Ve Veleslavínově překladu: „0 geometrickém vyměření země. Krátká zpráva a naučení / kterak se geometrickému vyměřování země dobře rozuměti má." (Bünting 1592, 36-41)

${ }^{418}$ „Beschreibung der Heiligen Stadt Jerusalem...” (Bünting 1587, 35-70) Ve Veleslavínově překladu: „Vypsání svatého a slavného města Jeruzaléma...” (Bünting 1592, 41-92)

419 "Vber das Buch Josua / ein sehr nütze vnnd Schöne Erklerung / von der Ausstheilung des Gelobten Landes Canaan / wie es vnter die zwelff Stemme Israel ist ausgetheilet worden." V magdeburském vydání z roku 1587 je zařazeno (se samostatným stránkováním) za první díl Itineraria. Ve Veleslavínově překladu: „Traktát o rozdělení země Kanaan / kterak ta mezi dvanáctero pokolení synův izraelských rozlosována a rozdělena byla." (Bünting 1592, 413-478)

${ }^{420}$ „De monetis et mensuris Sacrae Scripturae...” V magdeburském vydání z roku 1587 je zařazeno (se samostatným stránkováním) za druhý díl Itineraria. Ve Veleslavínově překladu: Bünting 1592, 479-530.

${ }^{421}$ Srov. Heijden 2001, 7-14. 
čtenáři poučení o nemalé části tehdy známého Orientu. Nejvíce a nejdůkladněji informovala ovšem o Svaté zemi, vedle ní však také o mnoha dalších místech a oblastech starověkého světa - Egypta (Memfis, Heliopolis, Tanis, Alexandrie), Sýrie (Seleukie, Antiochie, Palmyra, Damašek), Fénicie (Tyros, Sarepta), Mezopotámie (Ur, Babylon, Ninive, Súsy, Ekbatana) nebo Malé Asie (Smyrna, Efesos, Milétos, Bithynie, Galatie, Pontos, Frygie, Pamfylie, Kilikie) - a v omezené mir̃e dávala nahlédnout i do vzdálených končin Indie nebo Etiopie.

Veleslavínův překlad z roku 1592 českým čtenáůum zpřístupnil oba díly Itineraria, tj. jeho starozákonní i novozákonní část, včetně připojených pojednání, tedy včetně poučení o délkových mírách, obsáhlého popisu Jeruzaléma, výkladu o rozdělení kananejské země a spisku o penězích a mírách zmiňovaných v Bibli. Pro české vydání byly pořízeny kopie původních map, v nichž německé nadpisy a popisky byly nahrazeny českými, a podobně upravené kopie plánu starověkého Jeruzaléma a nákresu jeruzalémského chrámu, takže mapový a obrazový doprovod českého vydání věrně následuje vydání německé. Překladatel Daniel Adam z Veleslavína k českému vydání připojil dedikační předmluvu, adresovanou Karlovi Staršímu ze Žerotína a doporučující Büntingovu práci českým čtenářům. ${ }^{422}$

Pro českojazyčné prostředí měl Veleslavínův překlad Büntingova spisu zvláštní význam zejména proto, že v něm představoval ojedinělý pokus poskytnout ve vernakulárním jazyce alespoň část poznatků, jimiž v oblasti biblické geografie disponovala humanisticky vzdělaná západní Evropa. I v českém prostředí se sice v průběhu šestnáctého století objevovaly cestopisy psané národním jazykem a príbližující čtenářům některé části biblického světa (cestopisy Martina Kabátníka, Jana Hasištejnského z Lobkovic, Václava Prefáta z VIkanova), ale žádný soustavný spis podobný Büntingovu tehdy v českojazyčném prostředí nevznikl ani do něho před Veleslavínem nebyl uveden v překladu. Později na Veleslavínův pokus v některých směrech navázal původní česky psaný a k jisté encyklopedičnosti tínnoucí cestopis vydaný roku 1608 Kryštofem Harantem z Polžic a Bezdružic, ale ani ten Veleslavínovu

${ }^{422}$ Srov. Wildová Tosi 1999. 
práci nenahradil, jak snad mj. dosvědčuje okolnost, že o dva roky později, roku 1610, byl Veleslavínův překlad Büntingova Itineraria vydán Veleslavínovými dědici podruhé.

Dějiny recepce Veleslavínova překladu v českojazyčném prostředí nebyly dosud podrobněji zkoumány, takže představu o nich zatím můžeme mít jen velmi neúplnou. Zdá se však, že pro předbělohorskou šlechtickou a měštanskou kulturu bude $v$ nejednom ohledu charakteristická postava již zmíněného Kryštofa Haranta, který Büntingovu práci patrně poznal v některém jejím německém vydání a který se přitom v nějaké mîre seznámil i s jejím českým překladem, přinejmenším s předmluvou, kterou k ní Daniel Adam z Veleslavína připojil. ${ }^{423}$ Pro pobělohorskou dobu pak asi bude příznačné stanovisko Antonína Koniáše: tomu ovšem nemohlo uniknout, že v textu Ize najít formulace odporující učení katolické církve, avšak Veleslavínův překlad Büntingova spisu, jehož některých kvalit si patrně vážil, proto nezařadil mezi tituly určené k úplné likvidaci, nýbrž mezi knihy, které po provedení dílčích zásahů (začernění závadných míst, doplnění některých údajů) mohly být ponechány jako dovolená četba, a tak umožnil další širrení Veleslavínova překladu v českém prostředí. ${ }^{424}$ Že se pak skutečně i ve druhé polovině osmnáctého století mohl tento překlad uplatňovat jako živá součást českojazyčného písemnictví, a to i v katolickém prostředí, dokládá záznam milčického samouka Františka Jana Vaváka, který jej roku 1782 uvádí mezi knihami, které prošly jeho rukama a které četl. ${ }^{425} \mathrm{~V}$ lidovém prostředí se pak kniha zčásti udržela ještě i v devatenáctém století, jak mj. dokládají přípisky v jednom z dochovaných exemplárư. ${ }^{426}$

\footnotetext{
${ }^{423}$ Srov. Racek 1973, 38 a 179; Kopecký 1979, 92; Kopecký 1988, 208.

424 Koniáš 1749, 348-355.

425 Vavák 1908, 40.

426 Taich 1996, 179.
} 


\section{Literatura}

Bünting, Heinrich: Itinerarium Sacrae Scripturae, to jest Putování svatých na všecku Svatou Biblí obojího Zákona ... vydáno v jazyku německém, od M. Henricha Buntinga, faráře $v$ Grunově, a nyní v českém, od M. Daniele Adama z Veleslavína. Praha: Daniel Adam z Veleslavína, 1592.

Bünting, Heinrich: Itinerarium Sacrae Scripturae. Das ist / Ein Reisebuch, Uber die gantze heilige Schrifft... Magdeburg: Ambrosius Kirchner, 1587.

Heijden, Henk A. M. van der 2001: „Heinrich Büntings Itinerarium Sacrae Scripturae, 1581. Ein Kapitel der biblischen Geographie," in Cartographica Helvetica 23, 5-14.

Klinge, Hans 1955: „Bünting, Heinrich“, in: Neue Deutsche Biographie 2, 741 .

Koniáš, Antonín 1749: Clavis haeresim claudens et aperiens. Klič kacirské bludy k rozeznání otvírajicí, k vykořenění zamýkajíci..., Hradec Králové.

Kopecký, Milan 1979: Pokrokové tendence v české literature od konce husitství do Bílé Hory, Brno.

Kopecký, Milan 1988: Český humanismus, Praha.

Racek, Jan 1973: Kryštof Harant z Polžic a jeho doba. III. díl, část první. Dílo literární a hudební, Brno.

Taich, Vladimír 1996: „Putování po stránkách knihy o svaté zemi. (H. Bünting: Itinerarium Sacrae Scripturae v překladu D. A. z Veleslavína)", in: Východočeský sborník historický 5, 153-186.

Vavák, František Jan 1908: Paměti Františka J. Vaváka, souseda a rychtáre milčického z let 1770-1816. Kniha první (rok 1770-1783), část II. (1781-1783), Praha.

Wildová Tosi, Alena 1999: „Amor di patria e conoscenza del mondo nella prefazione di Daniel Adam z Veleslavína all'Itinerarium Sacrae Scripturae di H. Bünting", in: Sante Graciotti (ed.), Italia e Boemia nella cornice del Rinascimento europeo, Firenze, 289-304. 


\section{Kaukazská Albánia a jej obchodný význam pre Európu v období staroveku}

Už od staroveku prebiehali medzi Európou a Áziou čulé obchodné styky, ktoré sa realizovali prostredníctvom tranzitných obchodných ciest. Európski a ázijskí obchodníci využívali tieto cesty na prepravu tovarov. Dôležitú úlohu v tranzitnom obchode zohrávali križovatky obchodných ciest. V kontexte európsko-ázijského spojenia medzi takéto územia patrilo aj Zakaukazsko a v rámci neho oblast' Kaukazskej Albánie. ${ }^{427}$

Zakaukazsko bolo úzko spojené s významnými obchodnými cestami (ako napríklad známa Hodvábna cesta) už v období staroveku. Podla názoru azerbajdžanskej historičky S.B. Ašurbejli karavánové cesty tu existovali už v 2. tisícročí p.n.l. ${ }^{428}$ Cesty spájali oblasti Kaukazu s krajinami starovekého východu ako Egypt, Asýria, Perzia a iné. Východné Za-

427 Historická oblast', ktorá je v súčasnosti súčastou Azerbajdžanskej republiky. Hranice Kaukazskej Albánie sa v rámci jeho historického vývoja menili. Azerbajdžanský historik 19. storočia A.K. Bakichanov považoval územie Kaukazskej Albánie za neskoršie územie Širvánu a Dagestanu. Ako prvý exaktne zadefinoval jeho (ich) hranice takto: „Oblast' Širvánu je na východe ohraničená Kaspickým morom. Na juhozápade riekou Kura, ktorá ju oddeluje od oblasti Mugan. Na severozápade riekou Ganich (Alazani)... d'alej na severe Kaukazským chrbtom... až k toku rieky Darvaj, ktorá ústi do Kaspického mora." Hranice Dagestanu definoval takto: „Dagestan na východe hraničí s Kaspickým morom, na severe s riekou Terek, na západe s kabardinským a osetinským krajom, na juhozápade s Gruzínskom a na juhovýchode so Širvánom." Bakichanov 1991, 11-12, 13. Neskôr, hranice tohto územia podobne vymedzil aj ruský orientalista V.V. Bartol'd. Bartol'd 2003, 571.

428 Ašurbejli 1990, 13. 
kaukazsko je z antických diel známe pod názvom Albánia (alebo Kaukazská Albánia). ${ }^{429}$ Starovekí antickí autori vo svojich zápiskoch spomínajú, že cez túto oblast' prechádzali významné cesty vedúce na východ do Ázie. V kaukazskej oblasti sa križovali cesty zo severu na juh a z východu na západ. Dôležitú úlohu tu zohrávali priesmyky Porta Caspicae a Porta Caucasicae, ${ }^{430}$ cez ktoré prechádzali kupecké družiny. ${ }^{431}$ Tieto horské prechody spomínajú viacerí antickí autori aj v súvislosti s vojenskými pochodmi či presunmi kmeňov. ${ }^{432}$ Okrem týchto priesmykov významnú tranzitnú úlohu zohrávalo Kaspické more. Prvý grécky autor, ktorý zanechal správy o Kaspickom mori (Mare Caspium) bol Hekataios z Milétu. ${ }^{433} 0$ niečo neskôr sa o Kaspickom mori zmienil grécky historik Hérodotos. Ten o ňom napísal: „...Kaspické more je more samostatné a s iným morom nesúvisí. To more totiž, po ktorom sa plavia Gréci, spolu s morom za Heraklovými stípmi [Gibraltár], nazývaným Atlantický, ako aj Červené more, sú dohromady jedno more. Kaspické more je samostatné more a plavbou na veslici je dlhé pätnást' dní plavby a v najširšom mieste je široké osem dní plavby... Západnú stranu Kaspického mora

${ }^{429}$ Podla Strabóna Albánia je územie, ktorej na juhu hraničí s riekou Kura a tiahne sa od Kaspického mora po Kolchidu. Strabon 1964, 467. Podla názoru niektorých historikov - geografov, územie Albánie na severe a severozápade susedilo s Alaniou a krajinou Sarmatov, na západe s Ibériou (Gruzínskom) a Arménskom, na východe s Kaspickým morom a na juhu s riekou Kura a Araks, čo potvrdzujú aj pramene (Plínius Starší, Mojžiš Chorenaci, Mojžíš Kagankatvaci a i.). Neskôr Albánia bola známa pod arabsko-perzským názvom - Arran. Reza 2012, 32, 36.

430 Kaspická brána a Kaukazská brána boli všeobecné geograficko-historické pojmy, ktoré používali už starovekí autori na označenie kaukazských priesmykov. Tie spájali severné územia Kaukazu s južnými. Z toho vyplýva, že už v staroveku toto miesto zohrávalo dôležitú úlohu v rámci obchodného tranzitu medzi Európou a Áziou. Pozn. autora.

431 Jiroušek - Braun 1980, 7.

${ }^{432}$ Napríklad Flavius losephus, napísal, že prechod ovládal hyrkánsky král'a taktiež, že tento prechod nechal uzavriet' železnou bránou Alexandros (Alexander Vel'ký). Flavius losephus 1992, 224. Okrem neho Kaspickú bránu spomínajú aj d’alší antickí autori (Paulus Orosius, Themistios, Martianus Felix Capella). Pozri: Alijev 1986, 51, 53, 54.

${ }^{433}$ Grécky geograf a historik žijúci v 6.-5. storočí p.n.I. Okrem Kaspického mora (Mare Caspium) uviedol aj spomínanú Kaspickú bránu (Portas Caspias). Klausen (ed). 1831, 92-93. 
uzatvára Kaukaz..." ${ }^{334}$ Azerbajdžanský historik S. Velijev z Hérodotových slov usúdil, že už v 5. storočí p.n.I. bola na Kaspickom mori rozvinutá moreplavba a s tým spojený aj obchod. ${ }^{435}$ Okrem toho predpokladal, že na pobreží Kaspického mora museli existovat nejaké prístavy (napr. v ústi rieky Volga a Kura).436 Ďalší azerbajdžanský historik z 19. storočia A.K. Bakichanov poznamenal, že obyvatelia čiernomorských gréckych miest Tanais, Fanagoria či Hermonassa nadviazali obchodné kontakty s rôznymi národmi Kaukazu. ${ }^{437}$ Tieto staroveké mestá sa živo zapájali do tovarovej výmeny s Perzskou ríšou cez územie Kaukazu a Čierneho mora po starých karavánových cestách. ${ }^{438}$ Západné pobrežie Kaspického mora vrátane územia Albánie tak s vel'kou pravdepodobnostou mohlo byt zapojené do tohto obchodu. Ďalším antickým autorom, ktorý hovorí o existencii obchodnej cesty smerom zo Strednej Ázie cez Kaspické more, Albániu až k Čiernemu moru, bol grécky geograf Strabón. Ten v svojom diele poznamenal: "..cez Hyrkániu preteká rieka Ox [Amudarja] a Oks a vlieva sa do mora... a množstvo indických tovarov prepravujú cez ňu do Hyrkánskeho mora [Kaspické more], odtial' ich prepravujú do Albánie, cez rieku Kir [Kura] a potom ich privážajú do Euxeinos Pontos [Čierne more]." ${ }^{339} 0$ niečo neskôr rímsky historik Plínius Starší napísal: "..v čase boja Rímanov v Arménii upútala správa, že z Indie sa dopravili tovary k rieke Baktria, vlievajúcej sa do Oxu a po tejto rieke do Kaspického mora, d'alej po rieke Kyros [Kura] k miestu, z ktorého je pät' dní cesty k Pontu". ${ }^{400}$ Existenciu tejto cesty potvrdzujú aj slová d’alšieho rímskeho autora Gaia Julia Solina: „..za osem dní sa podarilo prejst' z Indie do Baktrie k rieke Daliera, ktorá sa vlieva do rieky Ox, potom ku Kaspickému moru a odtial'cez Kaspik preniknút' k rieke Kir, ktorá tečie po hranice Arménska a lbérie [Gruzínsko]. Od rieky Kir za viac než pät dní je

\footnotetext{
434 Hérodotos 2003, 94.

435 Velijev 1983, 23.

436 Velijev 1983, 23.

${ }^{437}$ A.K. Bakichanov taktiež poznamenal, že sa tu „zachovalo množstvo gréckych pamiatok." Bakichanov 1991, 32.

438 Rostovcev 2010, 30.

439 Strabon 1964, 482.

440 Plínius Starší 1974, 59.
} 
možné prejst' k rieke Fasis [Rioni]... Je dokázané na základe tejto cesty, že je možné z Indie do Pontu prejst' po vode." ${ }^{441}$ Zo slov spomínaných autorov je jasné, že už v období staroveku cez územie Albánie viedla obchodná cesta, ktorá spájala Európu a Áziu po trase: rieka Amudarja (Ox), Kaspické more, rieky Kura (Kir), Rioni (Fasis) a Čierne more.

Na prepravu tovarov sa $v$ tej dobe využívala aj cesta popri západnom pobreží Kaspického mora, ktorá spájala severné oblasti s juhom. Dôkazom sú slová Strabóna, ktorý zanechal opis tejto cesty (a jej vzdialenosti), vedúcej zo severu od Kaukazských hôr cez Kaspickú bránu. Ďalej viedla popri západnom pobreží Kaspického mora smerom na juh do Perzie. Strabón túto cestu opísal takto: „ Ku krajine Partov patrí Komisena a Chorena, tak ako aj všetky oblasti po Kaspickú bránu, po Rag a krajinu tapirov , ktorá predtým patrila Médií.. Od Kaspickej brány po Rag, podla slov Apollodora, 500 stádii a do hlavného mesta Partie - Hekatompila - 1260 stádii..." ${ }^{442}$ Aj táto cesta sa využívala na obchod, čo znova potvrdzujú slova Strabóna, ktorý napísal, že kmene "Horní aorsovia" obývajúce čast severného a západného pobrežia Kaspického mora viedli karavánový obchod na tavách s indickými a babylonskými tovarmi, ktoré získavali výmenou od Arménov a Médov. ${ }^{443}$ Okrem Strabóna sa s opisom tejto cesty môžeme stretnút u antických historikov Plútarcha a Corniela Tacita v súvislosti s vojenskými pochodmi cez Kaukaz. Plútarchos v životopise Caesara poznamenal, že samotný Ceasar po vojne s Partmi „....mal v úmysle prejst' cez Hyrkániu nahor popri Kaspickom mori a Kaukaze, obíst' Pont a vtrhnut do Skýtie..." ${ }^{444}$ Tacitus zanechal taktiež krátku správu o tejto pobrežnej ceste smerom zo severu na juh. Opísal ju však ako problematickú najmä z dôvodu „letných pasátnych vetrov". $445 \mathrm{~V}$ oboch prípadoch sa vel'kou pravdepodobnostou jednalo o tú istú cestu, ktorá sa využívala na obchodné účely.

\footnotetext{
441 Alijev 1986, 92.

442 Strabon 1964, 486. Okrem toho Strabón viackrát vo svojom diele spomenul, že táto cesta sa často využívala na prepravu.

443 Strabon 1964, 480.

444 Plútarchos 2008, 676.

445 Tacitus 1975, 253.
} 
V polovici 1. storočia p.n.I. sa o toto územie intenzívne začali zaujímat Rimania. Svedčí o tom výprava rímskeho velitela Pompeia, ktorý v roku 65 p.n.l. uskutočnil vojenskú výpravu do Albánie. Zmienky o tejto výprave pochádzajú najmä od Plútarcha. ${ }^{446} \mathrm{Hoci}$ prvoradým cielom Pompeia bolo prenasledovanie pontského král'a Mithridata, podla historika A. Kudrjavceva sa okrem toho „..Pompeius pokúšal preskúmat' známu obchodnú cestu, cez ktorú bolo možné nadviazat' kontakty s Indiou a Prednou Áziou. Nadviazanie obchodných kontaktov so severným Kaukazom a oblastami juhovýchodnej Európy a Predkaukazska cez hory Kaukazu a Prikaspickú cestu bolo pre Rím vel'mi dôležité" ${ }^{447}$ Je tak možné predpokladat, že Rimania mali záujem aj o obchodno-hospodárske ovládnutie tejto oblasti. Plínius Starší zanechal správu rímskeho cisára Claudia (41-54 n.I.) o projekte Seleuka, ktorého cielom bolo spojit Čierne more s Kaspickým morom prostredníctvom kanála. ${ }^{448}$ Kontrola obchodnej cesty, ktorá spájala západ s východom by bola pre Rím z hospodárskeho a politického hl'adiska výhodná. Podla názorov niektorých historikov, cesta vedúca cez Kolchidu, Ibériu a Kaukazskú Albániu bola najbezpečnejším spojením Ríma s východnými krajinami ${ }^{449}$ Neskôr Rimania územie Albánie opakovane "navštívili", o čom svedčí latinský nápis na skale pod horou Bojukdaš v Gobustane, objavený v roku 1948. Tento nápis pochádza z obdobia vlády cisára Domiciána (81-96 n.I.). ${ }^{500}$ Počas archeologických vykopávok $\checkmark$ Mingačevire ${ }^{451}$ bolo objavené vel'ké množstvo fibúl s priečnym emailom, ktoré sa radia medzi rímske výrobky z obdobia 2. až 7. storočia. ${ }^{452}$ Podla výsledkov výskumu, archeológovia predpokladajú, že to mohlo byt v staroveku významné centrum obchodu v Albánií. Antický geograf Klaudios Ptolemaios vo svojom diele vymenoval 29 miest Albánie,

\footnotetext{
446 Plútarchos 2008, 1004-1006.

447 Kudrjavcev 1982, 46.

448 Pachomov 1940, 30.

449 Džiddi 1981, 70.

450 Latinský nadpis znie: „Imp Domitiano Caesare Avg Germanic L lulius Maximus

> Leg XII Ful" V preklade: „Vláda Domiciána Cézara Augusta Germanskeho, Lucius Julius Maximus, Centurión XII Bleskovej Légie". Ašurbejli 1964, 28.

451 Mesto v súčasnom Azerbajdžane na brehu rieky Kura.

452 Ašurbejli 1957, 163.
} 
medzi ktorými sa nachádzalo sídlo Mamechia či Cabala (Gabala). ${ }^{453}$ V prípade Mamechie sa pravdepodobne jednalo o staroveké sídlo Šamacha. ${ }^{454}$ Tento fakt potvrdzujú aj archeologické vykopávky ned’aleko dnešnej Šamachy, kde sa našlo množstvo antických predmetov. ${ }^{455}$ Okrem toho, počas archeologických výskumov tak v Šamache (1958), ako aj v Gabale (1966) sa našlo množstvo strieborných mincí. ${ }^{456}$ Svedčí to o tom, že už v starovekom období Mamechia (Šamacha) a Gabala boli hospodárskymi strediskami, v ktorých sa viedol medzinárodný obchod. Popri nich sa tu nachádzali aj d’alšie významné sídla ako Adiabla, Baruca a iné. ${ }^{457}$ Tieto sídla mohli pravdepodobne zohrávat’ sprostredkovatel'skú úlohu v európsko-ázijskom obchode.

Od rímskeho prieniku do Zakaukazska začala Albánia nadobúdat́ významnejšiu úlohu v medzinárodnom tranzitnom obchode. Správy o obchodnej ceste cez rieku Ox, Kaspické more a d'alej na západ zanechali aj cestovatelia z Ďalekého východu. Čínsky historik Sim-Sian poznamenal, že čínski obchodníci vo vel'kom vyvážali rôzne tkaniny smerom na západ po uvedenej trase. ${ }^{458}$ Dokonca aj antickí autori spomínajú, že sa z východu na západ dovážali čínske tovary ako hodváb, hodvábne látky, korenie, aromatické prísady, slonová kost', fajansové a porcelánové výrobky a iné tovary. ${ }^{459}$ Kedže väčšinu vyvážaných tovarov tvoril hodváb, táto trasa sa stala známa ako „Vel'ká hodvábna cesta”. 460

\footnotetext{
453 Ptolemaeus, Claudius 1562, 184.

454 Ruská historička K. V. Trever vyjadrila pochybnost' v otázke presnej lokalizácie sídiel menovaných Ptolemaeom (okrem sídla Cabalaca). Kedz̃e názvy miest sa v priebehu historického vývoja stále menia, nie je možné na toponymickom základe jednoznačne stotožnit' vtedajšie názvy daných sídiel s dnešnými. Trever 1959, 137.

455 Ašurbejli 1990, 18.

456 Alijarly 2008, 99.

457 Ptolemaeus, Claudius 1562, 184.

458 Mamedov 2005, 20.

459 Ašurbejli 1990, 20.

460 Ruský orientalista V.V. Bartol'd poznamenal, že potom čo sa otvorilo obchodné spojenie medzi Čínou a Európou cez územie Partskej ríše, hlavným tovarom dovážajúcim sa do Európy bol hodváb, v starovekom Ríme známy pod názvom sericum (pravdepodobne prebraté z niektorého východného jazyka: čínsky - sy, kórejsky - sir, mongolsky - sirkek). Bartol'd 1911, 46.
} 
Existujú však aj iné názory vo vztahu využívania obchodnej cesty cez územie Albánie a Kaspické more. Ruský historik V. V. Bartol'd vyslovil pochybnost 0 tom, či obchodná cesta cez Kaspické more a Albániu bola $v$ tomto období skutočne využívaná. ${ }^{461}$ Usúdil to zo slov Theofana z Mytilénu, ktorý nám zanechal podrobný opis Albánie.462 Ten poznamenal, že v Albánií sa nezaoberajú plavbou po mori, pretože neprináša žiadny úžitok. ${ }^{463}$ Okrem Theofana neefektívnost' plavby po Kaspickom mori potvrdzujú slova rímskeho geografa Pomponia Mela, ktorý Kaspik opísal ako búrlivé more bez prístavov, kde sa dejú "morské divy", a preto ho moreplavci málo navštevujú. ${ }^{464} \mathrm{Aj}$ napriek týmto tvrdeniam u historikov prevláda názor, že Albánia a Kaspické more boli v období staroveku intenzívne zapojené do medzinárodného obchodu.

Neskorším dokladom o existencii ciest vedúcich cez územie Albánie je Peutingerová mapa (lat. Tabula Peutingeriana). ${ }^{465}$ Tá síce vznikla až v druhej polovici 13. storočia, ale bola vyhotovená pravdepodobne na základe Agrippovej mapy zo 4. storočia. ${ }^{466}$ Mapa znázorňovala predovšetkým cestnú siet Rímskej riše a slúžila na vojenské účely. Oblast' Albánie a Kaspického mora nie je zobrazená úplné presne, no dôkladnejším štúdiom mapy je možné vidiet, že aj cez toto územie viedli cesty, ktoré sa využívali tak na vojenské ako aj obchodné účely.

Územie Kaukazskej Albánie nestratilo svoj obchodný a tranzitný význam ani v období vlády perzskej dynastie Sásánovcov (224-652). Za ich panovania sa sem z východu dovážal čínsky hodváb, korenie, slonová kost', vzácne druhy dreva a iné tovary, ktoré sa potom d'alej vyvážali cez Čierne more a Byzanciu do Európy. ${ }^{467}$ V tej dobe sa o toto

\footnotetext{
461 Bartol'd, V.V. 1924, 11.

462 Dielo Theofana z Mytilénu sa nezachovalo, no do určitej miery z jeho diela čerpal grécky geograf Strabón, ktorý jeho meno v svojom diele Geografia spomenul. Pozri dielo: Strabon 1964, 468, 477, 497, 499, 521, 579.

463 Bartol'd, V.V. 1924, 11.

464 Alijev, K.T.-0. 1986, 87.

465 Kompletná mapa je dostupná aj v elektronickej podobe na webovej stránke, [cit.

04-05-2015]: <http://www.euratlas.net/cartogra/peutinger/index.html>.

466 Čapek, 1992, 341.

467 Ašurbejli 1957, 163.
} 
územie začala zaujímat́ aj Byzancia. V priebehu 3. až 7. storočia viedla so Sásánovskou ríšou neustály boj o ovládnutie tohto strategicky a hospodársky významného územia. ${ }^{468}$ Súperenie oboch ríš však výrazne nenarušilo tranzitno-obchodnú úlohu Kaukazskej Albánie.

468 K byzantsko-sásánovskému súperenie na Kaukaze pozri: Greatrex - Lieu 2002, 373. 


\section{Pramene}

Flavius losephus 1992: Válka židovská/ll. Trans. Jaroslav Havelka a Jaroslav Šonka [Svoboda, 266], Praha.

Hérodotos 2003: Dějiny aneb Devět knih dějin nazvaných Músy. Trans. Jaroslava Šonková [Academia, 551], Praha.

Klausen, R.H. (ed). 1831: Hecataei Milesii Fragmenta. Scylacis Caryandensis Periplus [Beroliny, Impensis G. Reimeri, 324].

Plínius Starší 1974: Kapitoly o prírodě. Trans. František Němeček [Svoboda, 352], Praha.

Plútarchos 2008: Životopisy slávnych Grékov a Rimanov. Trans. Daniel Škoviera a Peter Kuklica [Kaligram, 1052], Bratislava.

Ptolemaeus, Claudius 1562: Geographia Cl. Ptolemaei Alexandrini [apud Vincentium Valgrisium 184], Venetiis, [cit. 2013-03-22]. Dostupné na internete: <http://amshistorica.unibo.it/184>.

Strabon 1964: Geografija v 17 knigach. Perevod, statja i komentariji G.A. Stratanovskogo [lzdatel'stvo Nauka, 943], Leningrad.

Tabula Peutingeriana, [cit. 04-05-2015]. Dostupná na internete: <http:// www.euratlas.net/cartogra/peutinger/index.html>.

Tacitus 1975: Letopisy. Trans. Antonín Minařík a Antonín Hartmann [Svoboda, 554], Praha.

\section{Odborná literatúra}

Alijarly, S. (red.) 2008: Istorija Azerbajdžana. S drevnejšich vremen do 70-ch gg. XIX v. [Čiraq, 800], Baku.

Alijev, K. T.-o. 1986: Antičnyje istočniki po istoriji Azerbajdžana [ELM, 128], Baku.

Ašurbejli, S.B. 1990: Ekonomičeskije i kulturnyje svjazi Azerbajdžana s Indijej v srednije veka [ELM, 151], Baku.

Ašurbejli, S.B. 1957: „Remesla i torgovlja rannesrednevekovych gorodov Azerbajdžana", in: Trudy Muzeja istoriji Azerbajdžana. Tom II., 159-165. 
Ašurbejli, S.B. 1964: Očerk istoriji srednevekovogo Baku [lzdatel'stvo AN AzSSR, 336], Baku.

Bakichanov, A. 1991: Gjulistan-i Iram [ELM, 304], Baku.

Bartol'd, V.V. 1924: Mesto prikaspijskych oblastej v istoriji musulmanskogo mira [150], Baku.

Bartol'd, V.V. 2003: Raboty po istoričeskoj geografiji i istoriji Irana [Vostočnaja literatura, 663], Moskva.

Bartol'd, V.V. 1911: Istorija izučenija Vostoka v Jevrope i Rossiji [Tip. Stasjuleviča, 282], S. Peterburg.

Čapek, R. a kol. 1992: Geografická kartografie [SPN, 373], Praha.

Džiddi, G. A. 1981: Srednevekovyj gorod Šemacha (IX-XVII veka) [ELM, 175], Baku.

Greatrex, G. - Lieu, S. 2002: The Roman Eastern Frontier and the Persian Wars. Part II 363-630 [Routledge, 373], London; New York.

Jiroušek, A. - Braun, B. 1980: Kaukaz [Osveta, 180], Martin.

Kudrjavcev, A. 1982: Drevnij Derbent[lzdatel'stvo Nauka, 172], Moskva.

Mamedov, I. A. 2005: Velikij šelkovyj put' i Azerbajdžan [ELM, 118], Baku.

Pachomov, E. A. 1940: Obzor istočnikov po istoriji Azerbajdžanskoj SSR. Vypusk 1. Istočniki klinopisnyje, grečeskije, rimskije (latino-jazyčnyje), vizantijskije [lzdatel'stvo AzFAN, 51], Baku.

Reza, E.-o. 2012: Azerbajdžan i Arran (Aturpatakan i Kavkazskaja Albanija). Per. z pers. G. Asatrijan [Kvadriga, 200], Moskva.

Rostovcev, M. I. 2010: Karavannyje goroda. Per. K.A. Avetisjan [NestorIstorija, 216], S. Peterburg.

Trever, K. V. 1959: Očerki po istoriji i kulture Kavkazskoj Albaniji. IV. v. do n.e. - VII. v. n.e. [Izdatel'stvo Akademiji Nauk SSSR, 391], Moskva, Leningrad.

Velijev, C. 1983: Drevnij, drevnij Azerbajdžan [Gjandžlik, 148], Baku. 


\section{Summary}

Asia and Africa represent a vast territory which in course of their long historical development displays an astonishing range of local cultures and traditions. The individual cultures were often linked together and their interaction could have many forms. The civilizations that flourished in various regions of Asia and Africa during the long historical development of that territory exhibit a wide range of cultural traditions that are evident in various types of sources: in texts of economic, administrative, literary, religious and scientific nature as well as in three-dimensional objects such as tools, utensils or works of art.

Ancient Asian and African civilizations have been a traditional object of the scientific research which enabled the specialists to outline the main features of individual local cultures as well as to compare cultural traditions of Asian and African countries with those of other regions of the world. The present developments that heavily influence not only the Asian and African countries today, but have also an impact on the future of this territory root firmly in the local cultural traditions that are often traceable in the distant past. Therefore, the detailed and complex study of the history of ancient Asian and African civilizations within the context of their contacts to other cultural areas can contribute greatly to a better understanding ot the modern history of Asian and African countries. 
The monograph Vybrané aspekty kulturního vívoje Asie a Afriky [Selected Aspects of the Cultural Development of Asia and Africa] presents the results of 15 specific projects of scholars who are studying various aspects of the development of the material and intellectual culture of Asia and Africa during the long time span reaching from the Antiquity until modern times. Members of the team represent several scientific institutions from the Czech Republic as well as from Slovakia. Among scholars who participated in the research projects, we find historians, archaeologists, linguists, and other specialists.

The book is divided into three chapters devoted to following subjects:

1. Religion and languages

2. Politics and history

3. Contacts between West and East.

We hope that this book will be useful for those who are interested in the historical development and the rich cultural heritage of Asian and African countries. 